itithology and palynology of the Beiuga and Sterling Formations exposed near Honer, Kenai Peninsula, Alaska

by

W. L. Adkison, J. S. Kelley, and K. R. Newman

U.S, Geological survey open-iile report 75-383

1975

Prepared in cooperation with the Eivision of Geological and Geopingical Surveys, Department of Natural Resources, State of Alaska

This raport is prelininary and has not been adiced or reviewed for conjormity with U.S. Geologica! survev scandards and nomerclature. 
Contents

Page

Introduction - . . . . . . . . . . 1

Tertiary rocks - . . - . . . . . . . . 3

Renai Group - . . . . . . . . . . . . 10

Beluga Formation - . - . - . . - . . - 11

Lower part of Beluga Formation - . . . . . - Il

Upper part ố Beluga Formation - - . - - - - 15

Sterling Formation - - - - - - - - 20

Stratigraphic sections - - - . - . - . - 24

References cited - - - - - - - - - - 25

Measured sections - - - - - - - - - - 27

la. Sea-cliff and hillsicie exposures along shore of

Kachemak Bay from mouth of Diamond Creek, SW corner

SE $1 / 4$ NW 1/4 sec. 8, T.6 S., R. 14 W., rorthwestward to a point about 0.7 mile southeast of mouth of Travers Creek ("uitnaia Gulch), NW 1/4 SE $1 / 4$ NW 1/4 sec. 27, T. 5 S., R. 15 W., Seldovia C-5 quadrangle - - 27

1b. Hillside and sea-cliff exposures below Bluff Point 2, near center $: \mathbb{E} 1 / 4$ sec. 16, T. 6 S., R. 14 W., generally northwestward to mouth of Diamond Creek, SW comer SE $1 / 4 \mathrm{NW} 1 / 4 \mathrm{sec} .3$, T. 6 S., R. $14 \mathrm{~W}$. , Seldovia C-5 quadrangle. - . - . - . - 51

2. Creek-bed and hillsicie exposures on Biciarki Creek from near cen. : $1 / 4 \mathrm{SE} 1{ }^{\prime} 4 \mathrm{sec}$. 13 to sea cliff at creek mouth in Siv $1 / 4$ SE $1 / 4$ NW $1 / 4$ sec. 24, T. 6 S., R. 14 W., Seldovia C-5 quadrangle. - - - - 76 
3. Creek-bed and hillside exposures in Bear Canyon along upper part of Palmer Creek from SE $1 / 4$ sec. 3 southward to center sec. 10, T. 6 S., R. 13 W., Seldovia C-4 quadrangle $-\cdots$

4. Hillside and creek-bed exposures in large unnamed canyon about 1 mile northeast of Bear Canyon near center of sec. 2, T. 6 S., R. $13 \mathrm{~W} .$, Seldovia C-4 quadrangle.......

5. Gully exposure in head of unnamed canyon in NE $1 / 4 \mathrm{NE} 1 / 4$ sec. 2, T. 6 S., R. 13 W., Seldovia C-4 quadrangle.......

6. Gully and hillside exposures at forks of Swift Creek in NW 1/4 SW $1 / 4 \mathrm{NE} 1 / 4 \mathrm{sec} .23, \mathrm{~T} .4 \mathrm{~S} ., \mathrm{R}$. $11 \mathrm{~W}$, Seldovia D-3 quadrangle-

7. Hillside exposure on northwest side of Fox Creek about 50-200 yd. upstream from mouth of southeast flowing tributary (Locally known as Danny Creek) in E 1/2 SW $1 / 4 \mathrm{NW} 1 / 4 \mathrm{~s} \in \mathrm{c} .33$, T. $3 \mathrm{~S} .$, R. $10 \mathrm{~W} .$, Seldovia

D-3 quadrangle-

8. Hillside exposure in large unnamed west tributary of Fox Creek from SE corner SW $1 / 4$ SE $1 / 4 \mathrm{sec} .7$ southward to SW $1 / 4 \mathrm{NE} 1 / 4 \mathrm{NE} 1 / 4 \mathrm{sec} .18, \mathrm{~T} .4 \mathrm{~S} ., \mathrm{R} .10 \mathrm{~W}$. , Seidovia $D-3$ quadrangle

9. Hillside exposure in small oden canyon on west side $c \bar{i}$ Fox Creek in SE $1 / 4 \mathrm{NE} 1 / 4$ sec. 5, T. 4 S., R. 10 W., Seldovia D-3 quadrangle- 


\section{Measured sections--continued}

10. Gully exposure on west side of Fox Creek at center of north line NW $1 / 4 \mathrm{SW} 1 / 4 \mathrm{sec} .33$, T. $3 \mathrm{~S}$., R. $10 \mathrm{H.}$, Seldovia $D-3$ quadrangle-

11. Creek-bed and hillside exposures on Swift Creek from SE $1 / 4$ SW $1 / 4$ NE $1 / 4$ downstream to NW $1 / 4$ NE $1 / 4$ SE $1 / 4$ sec. 23, T. 4 S., R. 11 W., Seldovia D-3 quadrangle--1 175

12. Hillside and creek-bed exposures in large unnamed canyon on northeast side of Swift Creek in $\mathrm{N} 1 / 2 \mathrm{SE} 1 / 4 \mathrm{SW}$ $1 / 4$ sec. 24, T. 4 S., R. 11 W., Seldovia $D-3$ quadrang!

L1. Sea-cliff exposures about 1 mile southwest of Mclieil

Canyon in the NW $1 / 4$ SE $1 / 4 \mathrm{sec} .26$, T. 5 S., R. 12 W., Seldovia C-4 quadrangle-.

L2. Sea-cliff exposures southwest of McNeil Canyon in the SE $1 / 4 \mathrm{NW} 1 / 4 \sec .25$, T. 5 S., R. $12 \mathrm{~W}$., Seldovia C-d quadrangle-n.

L3. Sea-cliff exposures northeast of McNeil Canyon in the SW 1/4 SE $1 / 4 \mathrm{sec} .24$, T. 5 S., R. 12 W., Seldovia C-4 quadrangle-

44. Sea-cliff exposure west of Eastland Creek in the SW $1 / 4$ SW $1 / 4$ sec. 9 and SE $1 / 4$ SE $1 / 4$ sec. 3, T. 5 S., R. Il W., Seldovia D-4 quadrangle 
Measured sections--continued

L5. Sea-cliff northeast of Falls Creek in the NE $1 / 4$ SE $1 / 4$ sec. 3, T. 5 S., R. 11 W., Seldovia D-3 quadrangle-...-

L6. Stream-bed and canyon-wall exposures in unnamed canyon in the SE $1 / 4 \mathrm{NW} 1 / 4 \mathrm{sec} .36, T .4 \mathrm{~S}$, , R. $11 \mathrm{~W}$,

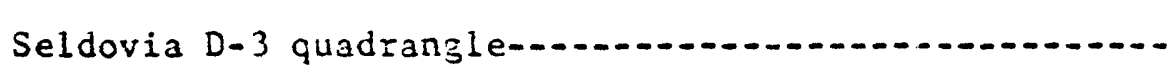

L7. West side of canyon of Swift Creek, in the Siv $1 / 4 \mathrm{NW} 1 / 4$ sec. 25, T. 4 S., R. 11 W., Seldovia D-3 quadrangle-..-

i3. Sea-cliff exposures in the SE $1 / 4 \mathrm{SW} 1 / 4$ sec. $26, T$. 5 S.,

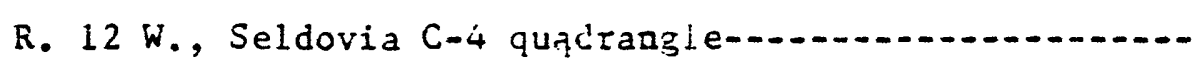

L9. Sea-cliff exposure west of measured section L8 in the NE 1/4 NW 1/4 sec. 35, T. 5 S., R. 12 W., Seldovia C-4́ quadrangle-

110. Sea-cliff exposure west of measured section L9 in the NW 1/4 NW 1/4 sec. 35, T. 5 S., R. 12 W., Seldovia C-4 quadrangle

L11. Sea-cliff exposure west of measured section L10 in the NW 1/4 NW 1/4 sec. 35, T. 5 S., R. 12 W., Seldovia C-4 quadrangle 228

L12. Sea-cliff exposures west of measured section LIl in the SW 1/4 NW 1/4 sec. 35, T. 5 S., R. $12 \mathrm{~W} .$, Seldovia C-4 quadrangle--

L13. Sea-cliff exposures west of measured section L12 in the SE $1 / 4 \mathrm{NE} 1 / 4 \mathrm{sec} .34$, T. 5 S., R. 12 W., Seldovia C-4 quadrangle-- 
Measured sections--continued

214. Sea-cliff expcsures west of measured section L13 in the

SE $1 / 4$ NE $1 / 4$ sec. 34, T. 5 S., R. 12 W., Seldovia

C-4 quadrangle--

L15. Sea-cliff exposures west ot measured section L14

in the SW $1 / 4 \mathrm{NE} 1 / 4 \mathrm{sec}$. 34, T. $5 \mathrm{~S} ., \mathrm{R} .12 \mathrm{~W}$,

Seldovia $\mathrm{C}-4$ quadrangle-_.

L16. Sea-ciffe exposures west of measured section L1j in the

SW $1 / 4 \mathrm{NE} 1 / 4 \mathrm{sec}$ 34, T. $5 \mathrm{~S} ., \mathrm{R} .12 \mathrm{~W} .$, Seldovia

C-4 quadrangle-.

L17. Sea-cliff exposures west of measured section L16 in the

NE 1/4 SW $1 / 4 \mathrm{sec} .34$, T. $5 \mathrm{~S}$, , R. $12 \mathrm{~W} .$, Seldovia

C-4 quadrangle-

L18. Sea-cliff exposures rest of measured section $L I T$ in the

NE $1 / 4 \mathrm{SW} 1 / 4 \mathrm{sec} .34$, T. 5 S., R. 12 W., Seldovia

C-4 quadrangle- 4

$23 n$ 


\section{Tables}

Page

Table 1. Checklist of palynomorph taxa in measured section la,

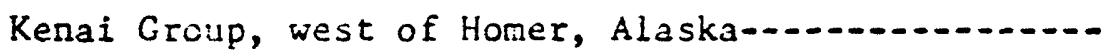

2. Checklist of palynomorph taxa in measured sections

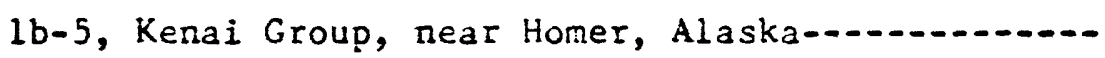

3. Checklist of palynomorph taxa in measured sections

L1-L18, Kenai Group, alonj Kachemak Bay northeast

of Homer, Alaska-_.

4. Checklist of palynomorph taxa in measured sections 6-12. Kenai Group, on Switt and Fox Crueks near head of Kachemak Bay, Alaska-

\section{Illustrazions}

Plate 1. Stratigraphic sections of Beluga and Sterling Formations near Homer, Kenai Peninsula, Alaska (In pocket on the inside back cover) 


\section{Introduction}

This report provides detailed lithologic descriptions and lists palynomorph assemblages of the Beluga and Sterling Formations, Kenai Group, of Tertiary age at selected exposures in the southern part of the Kenai Lowland near Foner, Alaska (pl. I). A preliminary report on the heavy minerals in these rocks is being prepared by $\mathrm{K}$. T. Biddle. This work is part of a study to provide stratigraphic control to aid in the search for oil and gas in the Cock Inlet basin.

The work was done under a cooperacive agreement between the U.S. Geological Survey and the Division of Geological and Geophysical Surveys, Department of Natural Resources, State of Alaska, The writers gratefully acknowledge the assistance of $W$. C. Fackler, Deputy Comissioner, Department of Natural Resources, and D. C. Hartman, former State Geologist. Discussions of the geology near Homer with $C$. E. Kirschner were very helpEul.

Field work for this report was done in the summer of 1972 by Adkison and Kelley and in late Yay and jure 1973 by these writers and E. R. Landis and $K$. T. Biddle. Sections measured by Landis and Biddle are designaced by the letter "L". The palynomorphs were identified by Newman who was assisted by Linda Lewis.

In the field the rocks in each measured section were described from bottom to top, and this order is used here to sumarize the descriptions. The detailed descriptions, starting on page 27 , are in downward order for each section. The section numbers ( 1 a-i2, L1-L18) are field numbers and indicate the order in which the sections 
were measured by the two field parties. The field descriptions commonly included, for each rock cype, the color, staining, weathering characteristics, bedding, induration, grain size, accessory particles, fossils, and the contact with the overiying rock unit. Thicknesses were generally measured with a steel tape and hand level, but an Abney level and Jacob's staff were used for parts of some sections. Concurrently with the field description, Adkison and Kelley collected representative lithologic samples of all rock units; Landis and Bidale tock selected lichologic samples. The samples were briefly stidied later by kelley and Biddle, using lowfower binocular microscopes, in order to sheck and ampifif the field descriptions.

The Rock Color Chart (Goddard and others, 1948) was used to cescribe the rock colors, and the Wentworth grade scale was used to describe the grain size. Clastic rocks composed chiefly of particles smaller than coarse silt were generally cermed "shale" by Adkison and Kelley, although the bedding of these rocks is comonly obscure or poorly developed. Similar rocks were called "claystone" by Landis and Biddle. The term "siltstone" is used for clastic rocks composed of coarse-silc particles. Bedding is classified according to thickness as follows:

$$
\begin{array}{ll}
\text { fissile, less that } 1 / 16 \text { in. } & \text { thin, } 2-4 \text { in. } \\
\text { platy, } 1 / 16-1 / 2 \text { in. } & \text { medium, } 4-12 \text { in. } \\
\text { very thin, } 1 / 2-2 \text { in. } & \text { thick, } 12-36 \mathrm{in} .
\end{array}
$$

massive, wore than 36 in。

The palynological samples were coilected from the finer grained clastics (shale, claystone, and siitstone) that comonly form the flcor, 
partings, or the roof of coal beds (p1. 1). Efforts were made to get relatively fresh samples uncontaminated by pollen and spores from modern vegetation. The samples were placed in plastic bags that were closed with tie wires and then placed in tagged cloth bags.

The palynological samples were treated with acids to remove minerals and concentrate acid-resistant organic-walled microfossils (palynomorphs). Nearly all samples had numerous to abundant palynonorphs, chlefly spores and pollen, and these were generally well preserved. Organic residues from the samples were mounted on slides and examined qualitatively to determine the stratigraphic succession of palynemorphs. The taxa found in this study are listed in tables $1-4$. Tertiary Rocks

The name "Kenai" nas been applied to the Tertiary coal-bearing rocks along the northwest shore of Kachemak Bay since the early work of Dall and Harris (1892). The Kenai Formation was mapped and described by Bannes and Cobb (1959) in a study of the geology and coal resources of the Honer district, and their report was used extensively during field work for the present report. Plant fossils in the Kenai were studied by ivolfe, Hopkins, and Leopold (i966), who proposed inree new provincial time-stratigraphic units -- the Seldovian, Honerian, and Clamgulchian Stages -- for much of the Kenai Fornation exposed in the Cook Inlet region.

Drilling by the petroleum industry since 1957 showed the thickness of the Kenai Formation greatly exceeds the total thickness of surface exposures. As pointed out by Calderwod and Fackler 


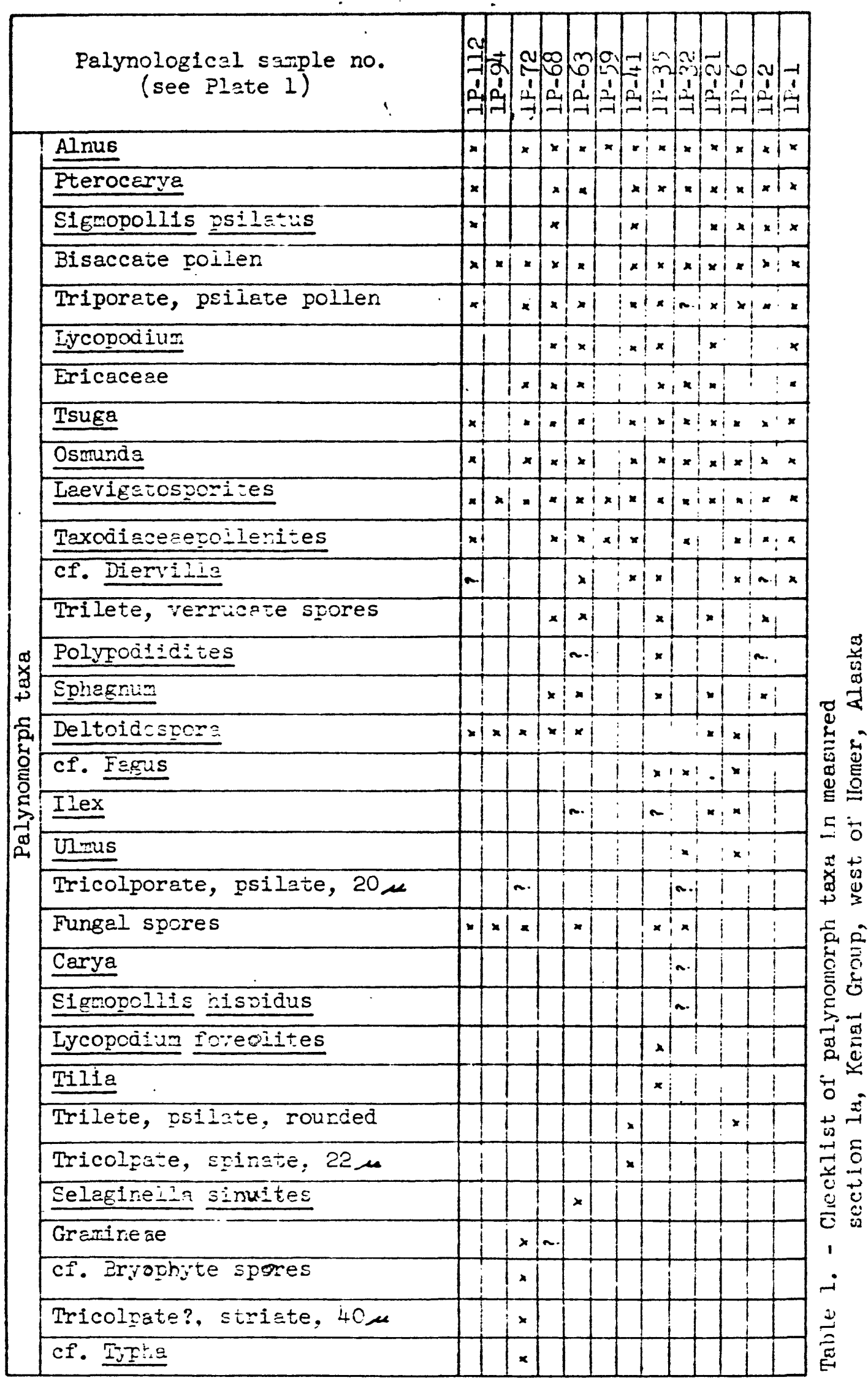




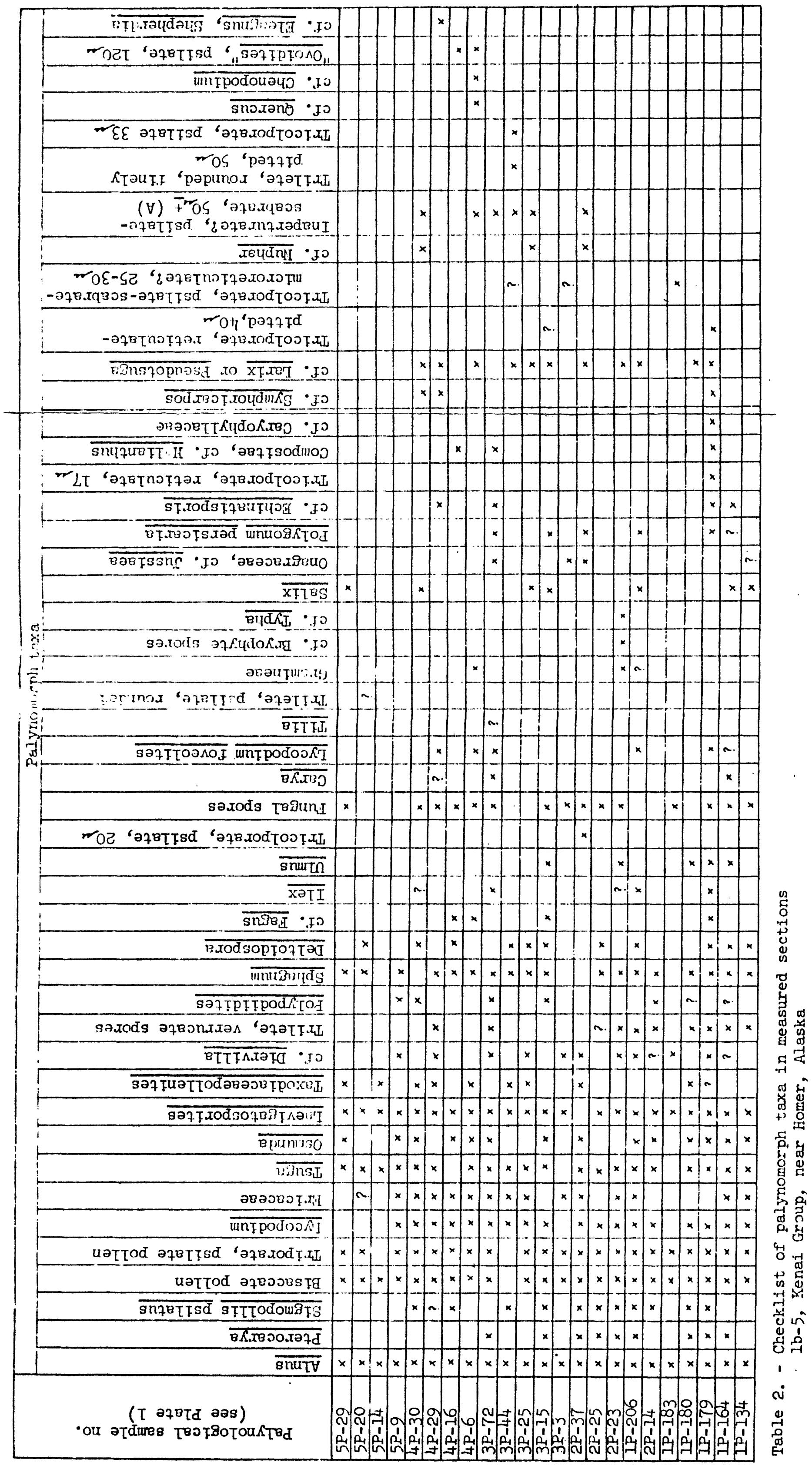




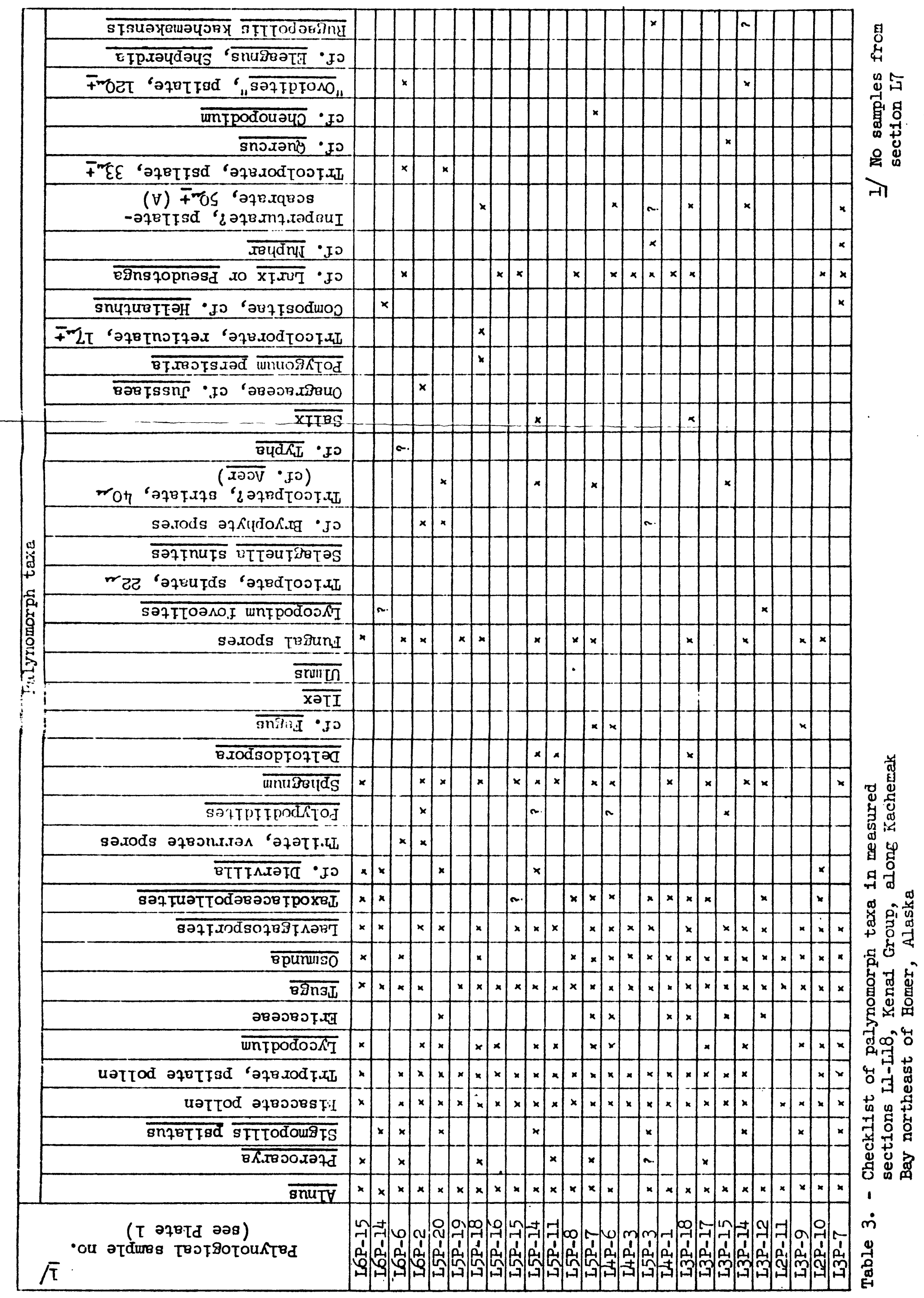




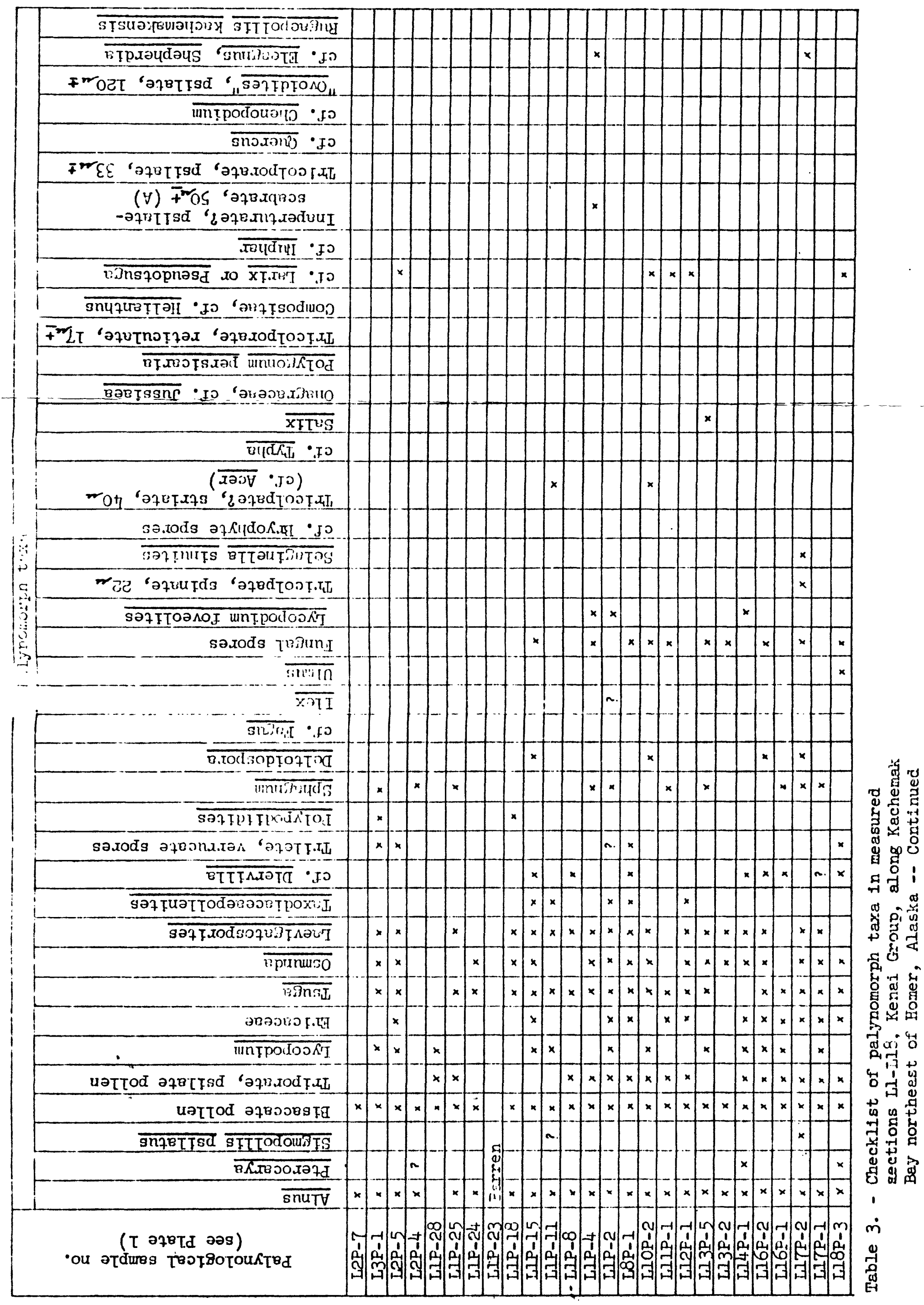




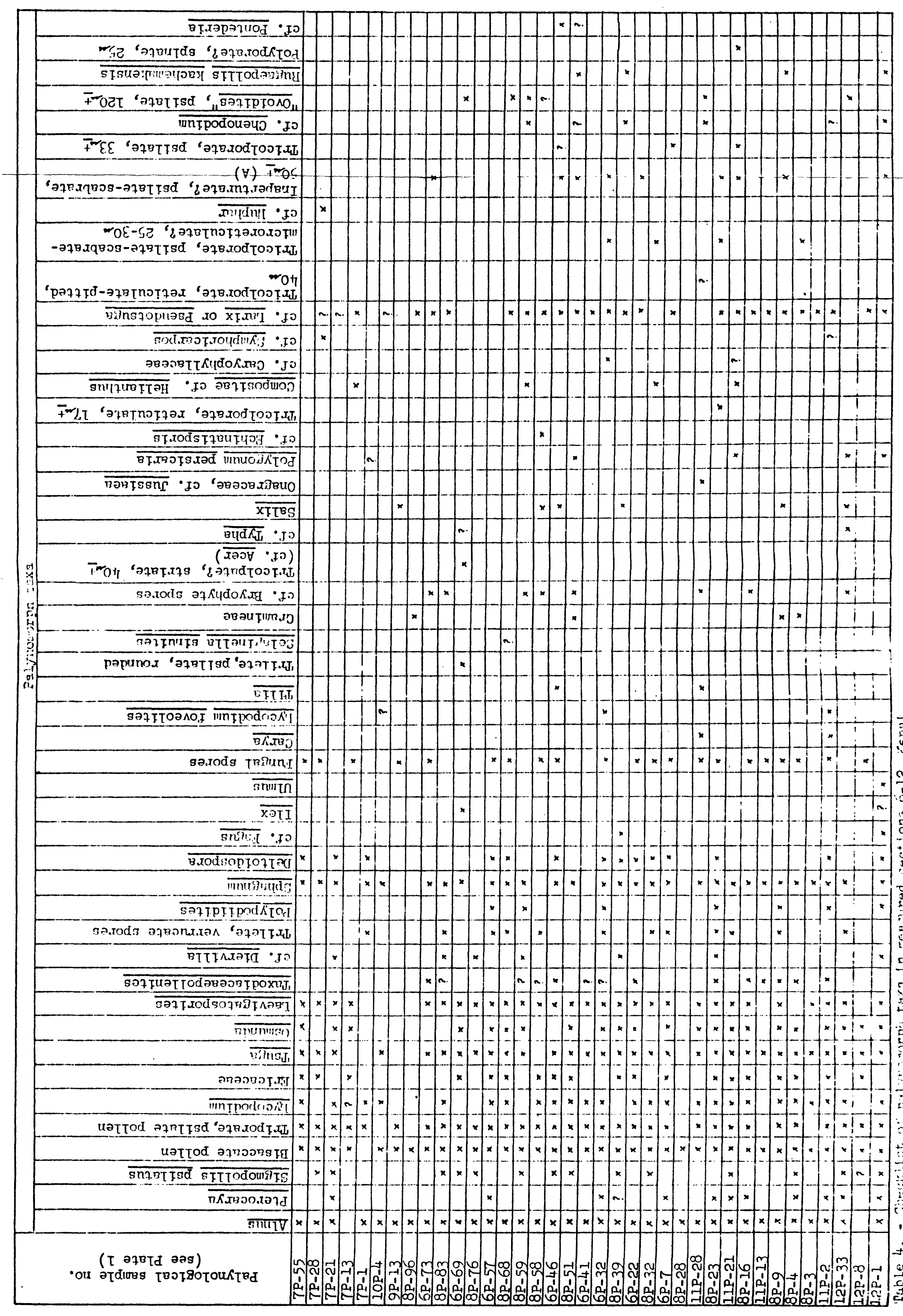


(1972, p. 741), the name "Kenai Formation" is inadequate to describe the gross sequence of Iertiary rocks, and accordingly, they formally

proposed: (1) the Kenai Formation be elevated to Kenai Group and (2) this group be divided into five formations named, in upward order, the West Foreland Formation, Hemlock Conglomerate, Tyonek Formation, Beluga Formation, and Sterling Formation. This stratigraphic nomenciature is widely accepted by geologists vorking with the subsurface stratigraphy in the Cook Inlet basin, and it is used in this report.

All fortations of the Kenai Group have subsurface type sections, and it is generslly difficult to trace these units to surface exposures. In the Homer area Kenai rocks of the Homerian Stage (Wolfe and others, 1966) were correlated with part of the Beluga Formation by Calderwood and Fackier (1972, p. 748). These writers (p. 751) stated that parts of the Sterling Formation crop out along the western margin of the Kenai Peninsula where Wolfe, Hopkins, and Leopcld (1966, p. A20) designated the type section for the Clamgulchian 3tage. According to an isopach wap by Hartian, Dessel, and McGee (1972), the Sterling is absent in six wells (Nos. $1,2,7,8,9,10, \mathrm{pl}, 1$ ) located in the southern part of the Kenai Lowland; in these wells the youngest Kenai strata were assizned to the Beluga Formation. Exposures of the Beluga and Sterling Formations in the southern part of the Eowland are wapped in a generai way by Kirschner and Lyon (1973, fig. il). 


\section{Kenai Group}

The Kenai Group exposed in the Homer area consists of nonmarine moderately weil indurated clastic rocks that are assigned to the Beluga and Sterling Formations. This subdivision is based on lithology, subsurface stratigraphy, palynology, and heavy-mineral study. The approximate areal extent of these iormations in the southern part of the Kenai Lowland (south and east of Anchor River) is shown on the location map on plate 1. The location of the contact between the Beluga and Starling, not mapped in the field, is sketched using the measurements of structural attitude shoin on the geologic map by Barnes and Cobb (1959, p1. 18) and the estimated altitude of the contact below measured section 5 .

The total thickness of the exposed Beluga and Sterling Formations is estimated at 6,100 feet; Barnes and Cobb (1959, p. 225) estimated the thickness at 5,000 feet or more. The thickness is difficult to determine because a lack of marker beds aakes correlations only approximate across large covered areas and also across two conceaied or inferred faults of uninown displacement (location map, ?1. 1). In the southern part of the Kenai Lowland, the greatest thickness of the combined Beluga and Sterling, including Quaternary strata if present, is 6,940 feet in well 5 (location map, p1. 1), according to Hartman, Pessel, and If Gee (1972).

For ease of description, neasured sections la through 5 are designated the Homer Section, and measured sections Il through L18 plus 6 through 12 are designated the Kachemak Section ( 1,1$)$. 
Both sections extend over considerable distances, and as described below, the rocks are broken by numerous fauits, A major concealed fault probably separates the Homer and Kachemak Secrions. Beluga Formation

At the south end of the Kenai Lowland, the Beluga Formation crops out in the sea cliffs northwest of Homer, along the Homer Escarpment, and in the sea cliffs on the north side of upper Kachemak Bay. The base of the formation is not exposed. The total thickness of tine exposed beds, 3,080 Feet, is oniy approximate because of difficulties in correlating beds across covered areas. In the southern part of the Lowland (Iocation aap, p1. 1), the thickness of the Beluga is as much as 3,590 Eeet in weil 4 (Hartman and others, 1972). The continuity of the formation in the nomer Section probably is broken by a concealed fault at the zouth of Diamond Creek, and the lower and upper parts ace described separately。

Lower part of Beliga Formation. -- The lowermost part of the Homer Section includes the oldest rocks of the Beluga Formation. This seacliff exposure, measured section la (pl. 1), extends from a point about 0.7 mile soutneast of the mouth or Travers Creek (Mutnaia Guich) southeastiard to Diamoni Creek. The strata lia in the lower part of the type section of the Homerian stage as defined by Wolfe, Hopkins, and Leopold (1965, p. Al7). Rccks of this stage are at least partiy late Miocene in age, but the voungest part may be of early Pliocene age (wolfe and others, 1965, D. A20). 
Rocks in measured section la generally show a gentie apparent dip to the southeast, although beds in the middle part appear nearly flat lying. The total thickress is about 865 feet, but some beds may be missing as a result of faulting. Rocks of section la are bounded on the northwest by a fault zone about 200-300 yards wide. On the southeast side, sections $1 \mathrm{a}$ and $1 \mathrm{~b}$ probably are separated by a fault that is concealed by colluvial and alluvial deposits at the routh of Diamond Creek. Rocks in the lower and widdle parts of section la probably are cut by a few faults of apparently small displacement, but these are generaliy concealed by Pleistocene ieposits.

The Beluga Formation in section la consists of sandstone interbedded with siltstone, shale, and coal. These rocks, except for the coal, are mostly medium gray and partly iron stained. Bedding in the finer clastics is cormonly obscure. The sandstone is dominantly very fine to Zine grained, silty, and clayey. A few sandstone bodies are friable. Basal parts of some sandstone units are medium to coarse grained and locally pebbly. These units, probably channel deposits, generally have sharp bases, show cross bedding, and become finer grained and increasingly silty upward. Calcite locally cements parts of many sandstone bodies into hard concretionary forms. Some sandstone beds include scattered coal iragments and stringers. The siltstone raries from sandy to clayey, and locally it is partly limy and concretionary. Some thin siltstone beds, commonly partings in coal beds, are brown or brownish gray and concain clear angular 
sandsize fragments of feidspar. These fragments appear ralatively unweathered and probably are of pyroclastic origin. The shale and claystone are silty to sandy and, for the most part, are pocriy bedded or nonbedded. Dark-gray to black carbonaceous shaie occurs in many thin beds that generally lie in ciose proximity to coal beds. The carbonaceous shale is tissile to platy bedded, and it comonly-includes very thin coal stringers. Ircnstone occurs mainly as nodules, as much as 0.6 foot thick, in fairly regular courses; the ironstone is found chiefiy in gray shale and siltstone.

Coal beds are abundant in the Beluga Formation in section la, and several are 3 to 5 feet thick. The coal is well indurated and comonly weathers blocky. It is more resistant to weathering than most of the other rocks, and it forms ledges and waterfalis at many places along the seacliffs. The color is mostly dull black, but bright bands are fairly common in fresh exposures. Swall fragments of amber are scattered in numerous coal beds in the lower half of section $l_{3}$ but were noted in only one bed in the upper half. Almost all the thicker coais include one or more partings of clastic rock. Many of the partings contain cryscal fragments of probable pyroclastic origin.

Fossils in the rocks of section la consist entirely of plant fragments and palynomorphs. The Fragments vary considerably in size and are more comonly present in shale, siltstone, and ironstone. Plant fragments appear to be in growth position in some beds, and in other beds they are randomly oriented. Leaf impressions were 
found in a sandstone in the lower part of the section and in a siltstone in the upper part (p1. 1). The siltstone might be the same bed that was sampled at U.S.G.S. Paleobotany locality 9356 (wolfe and others, 1966, F. A26), but this cannot be determined. The pollen assemblage from section la (table 1) appears to be younger than pollen assemblages from the Iyonek Formation exposed near the toe of Capps Glacier and along part of Chuitna River on the northwest flank of Cook Inlet basin (Adkison and others, 1975). This age relationship is in agreement with studies of the megariora in Kenai strata by Wolfe, Hopkins, and Lecpold (1966)。 These writers included the rocks in the Capps Glacier-Chuitna River area in the type section of the Seldovian Stage. They determined that the Seldovian Stage is older than the Homerian Stage, the type section of which includes strata of section la. There are similarities between the pollen assemblage from section la and those found by Newman (written commun, 1975 and Adkison and Yewman, 1973) in cuttings and cores from the upper part of the Iyonek Formation (between approximate depths 7,100-8,000 ft.) in the standard 0il Co. of Cal. I Deep Creek init well, Iocated about 25 miles north of Homer.

The heavy-mineral suites in five sandstones from section la were studied by $k$. I. Biddle (in preparation). He found the principal heavy minerals are, in order of decreasing average percent, siderite, sphene, epicote, garnet, andalusite. According to Kirschner 
and Lyon (1973, p. 404), a predominance of epidote in the heavy minerals from the Beluga indicates an eastern source area in the Kenai and Chugach Mountains.

As noted above, section la probably is separated from section ib by a normal fault that is concealed at the mouth of Diamond Creek. Rocks in the uppermost part of section la dip southeast toward Diamond Creek; beds on the southeast side of the creek, the basal part of section 1b, appear almost flat lying in the seacliff. The southeast block probably is downthrown, but the amount of displacement is unknown. Upper Part of the Beiuga Formation. The upper part of the Beluga Formation in the Homer Section, about 2,215 feet thick, includes the rocks in sections $1 b, 2,3$, and most of section 4. Correlation of these sections follors Barnes and Cobb (1959, p1. 19). Rocks in these sections are, for the most part, very similar lithologically to those in s'rtion 1a, but there are some differences as discussed below.

The lower part of section lb includes a mediun-gray very silty shale unit, 53 ieet thick, that has a pronounced conchoidal fracture. This uncommonly thick shale unit, marked at the base by sample 1P-134 ( $p 1.1$ ), weathers distinctively because of the conchoidal Eracture. Iron staining is generally abundant on joints and fractures. The lower part of the shale contains scattered fine to coarse sand grains and granules. A sample of the shale was examined by $G$. W. Andrews, U.S. Geological Survey (written comun., 1974). He found 
common to abundant diatom debris, mostly too finely broken for meaningful study, but he identified four nonmarine taxa- Melosira islandica ssp. helvetica 0 . Muller, Coscinodiscus Lacustris Grunow?, Melosira granulata (Ehrenberg) Ralfs, and Tetracvclus sp.

In the upper part of the Beluga Formation (sections 1b-4), coal beds a foot or more in thickness (including tnin partings) are stratigraphically much more widely spaced than those in section la. Fragmencs of amber were noted only in the Cabin coal jed in section 3. Grains of probable pyrodlastic origin seem much less common in the partings of coal beds, aithough the brownish-gray color of some partings suggests pyroclastic material way be included. Leaf impressions and large coalified wood fragments, including flattened logs, are more numerous in the upper part of the formation. At least 11 beds in the midile and upper parts of section 3 contain leaf impressicns ( 1.1 ).

Beds of friable sandstone are more common in the upper part of the Beluga Formation, and the sandstone is generally iess clayey than that in section 1a. Thin limy concretionary zones in the sandstone and siltstone are almost as numerous in section $1 b$ as in la. Iimy zones are scarce in section 3 , and none were seen in section 4 .

The upper part of the Beluga Formation in the Homer Section, described above, cannot be traced directly to exposures in the seacliffs of the Kachemak Section. Quaternary deposits cover the formation in a northeast-trending lowland band, about a mile wide, that separates the Homer Escarpment from the seacilifis of the Kachemak Section (Barnes and Cobb, 1959, pl. 18). In addition, a major concealed fault probably passes 
northeastward through this covered area (Beikman, 1974). The fault probably passes between two wells in T. 4 S., Rs. 11 and 12 W. (wells 5 and 6 , location map, p1. 1). Well logs indicare the northwest side is downthrown or, if there is little cr no displacement on the fault, the pre-Tertiary erosion surface dips rather steeply toward the northwest. Near the Homer Escarpment, the displacement of the near-surface rocks along the fault is unknown.

Rocks of the upper part of the Beluga Formation in the Homer Section are tentatively correlated with generally similar strata in the Kachenak Section (pl. 1). The correlation is based primarily on rough similarities in the sequence of pollen taxa (tables 2, 3). Some taxa occur rather consistently in the sections, but many others occur erratically. The lowest stratigraphic occurrence of a few taxa in the exposed rocks are indicated on plate 1. These limits are only approximate and are not necessarily applicable to the entire Kenai Group.

In the Kachemak Section located in the seacliffs northeast of Homer, the Beluga Formation includes rocks in measured sections L18-L8, L1-I3, and parts of L4 and L5 (pl. 1). Correlation of these sections follows Barnes and Cobb (1959); they measured additional strata below section L18. The rocks are mostly well exposed, have a low generally north dip, and are broken by numerous normal faults with displacements as much as 77 feet (Barnes and Cobb, 1959, pl. 18, p. 228). J.A. Wolfe (1975, oral commun.) assigns the lower and niddle parts of these beds to the Homerian Stage and the upper part (above coal bed B) to the Clamgulchian Stage. 
The Beluga Formation in the Kachemak Section consists of sandstone, claystone (mostly cermed "shale" in preceding description), siltstone, shaie, and many scal beds. The thickness of the described beds is about 1,325 feet. As illustrated by Barnes and Cobb (1959, pl. 19), stratigraphically lower rocks are present southwest of section L18, but time was insufficient to study then. The clastic rocks are chiefly medium gray to medium dark gray, and beciding of the finer clastics is generally obscure or poorly developed. Most sandstone is thick to massive bedded, soft, very fine to fine grained, silty, and clayey. Much of the sandstone is friable. Numerous sandstone bodies may be channel deposits; these seem more abundant in the lower half of the exposures. The channel deposits are generally similar to those described above. One sandstone in the lower part (section LI7) contained pebbles and scattered cobbles. Claystone in the Reluga is generally silty, and the siltstone is mostly clayey. The distinctive conchoidal-weathering shale, with included diatom debris, in the lower part of section $1 \mathrm{~b}$ was not recognized in the seacliff exposures northeast of Homer. The tentative palynological correlations suggest that, if this shale is present in the Kachemak Section, it lies a few hundred feet below sea level. Limy concretionary bodies are found in siltstone, sandstone, and claystone; these bodies are more common between coal beds $A$ and $D$. Thin beds of carbonaceous or coaly shale are generaliy associaced with $\operatorname{col} 1$ beds. Although the formation includes many coal beds, the thicker beds are restricted to the upper half of the rocks studied for this report. No amber fragments were noted in the coal. 
Partings of clastic rock are presenc in most of the thicker coal beds; grains of probable pyroclastic origin seeningly are rare in the partings or in other beds.

The only fossils found in the Beluga Formation in sections L18-L5 consist of carbonaceous plant frigments and palynomorphs. In these sections, the palynomorph taxa (table 3) occur much more erratically than in sections of the Beluga described above, and the average number of taxa per sampie is considerably less than for other large parts of the Kenai strata described in this report. No leaf impressions were noted, and large woody carbonaceous piant Eragments are rare.

The top of the Beluga Fcrmation in section ij ( $p i .1$ ) is tentativaly placed at the base of a thick sandstone unit that probably is a channel deposit. The position of this contact is broadly determined by an upward change in the heavy-mineral suites as generally outlined by Kirschner and Lyon (1973, P. 404). According to K. T. Biddle (in preparation), the heavy minerals from a sandstone near the middle of section $\mathrm{L} 3$ consist mainly of epidote and small amounrs of zircon, garnet, sphene, ard several other winerals. Biddle found the heavy-mineral suite from the basal sandstone of the Sterling Formation (section L5) is dominated by hypersthene and hornblende. The top of the Beluga in section L4, about 2.4 miles to the southwest, is placed at the base of a sandstone and siltstone sequence about 12 feet thick.

In the Homer Section (section 4, pl. 1), the top of the Beluga Formation is tentatively placed at the base of a thick sandstone unit that appears to be a channel deposit. The contact, probably a minor 
local disconformity, is determined in seneral accordance with the palynological correlations. The top of the Beluga in the Homer Section is not marked by the change in heavy minerals found in the Kachemak Section. The study by Biddle (in preparation) showed that the upward change fror a suite dominated by epidote to one composed mainly of hypersthene and hormblende occurs at a lower stratigraphic position in the lower-middle part of section lb. The lack of parallelism betreen the tentative palynological correlations and the heavy-minerai currelation cannot be explainei with the available data. The heary-mineral samples in the Homer and Kachemak Sections are, for the most part, rather widely spaced stratigraphically. Study of additional samples might indicaze the change in heavy-mineral suites occurs at a different stratigraphic position in either or both sections. Also, an interfingering relationship, wherein the contact between the suites rises stratigraphically northeastivard, wight be interpreted from additional study。 Scerling Formation

The Sterling Formation of the Kachemak Section crops out in the seacliffs in the upper (northeastern) part of Kachemak Bay and in the valley walls of several streams that Elow generai: $\because$ southivard inco the bay. In this area folfe, Hopkins, and Leopold (1966, p. A20, A2i) designated a reference section for the Ciamgulchian Stage and explained the evidence indicative of a Pliocene age for this stage. In the Homer Section the lower part of the fcrmation is also exposed in the upper parts of several canyons cut into the Homer Escarpment. Rocks of the Sterling Formation of both sections generally dip northwest at about $3^{\circ}-5^{\circ}$. 
The youngest beds are unconformably overlain by Pleistocene deposits about $1.2 \mathrm{mi}$. south of Caribou Lake (location map, pl. 1),

Rocks of the sterling Formation measured in the Kachemak Section are traceable for considerabie distances along parts of the valley walls of Swift, Moose, and Fox Creeks, but extensive covered areas, especially between the loiver parts of these streans, prevent direct tracing of beds from one drainage to another. An exposure including both ccal beds $M$ and $N$ (sections $i 6,12$ ) was not found. The interval between these coal beds was roughly calculated at 500-800 feet, but it might be somewhat greater.

The rocks exposed in the upper half of Swift Crsek (sections 12, 11, 6) are tentatively correlated with those on Fox Creek (section 8) about 2.5 wiles to the northeast and approximately along regional strike. The correlations are based mainly on the presence and relative position of several fairly thick coal beds, especialiy beds $0, ?, Q, S$, and $T$, and to some extent on general Iithologic similarities of the other rocks. No distinctive marker beds were found in this part of the Sterling Formation.

On Fox Creek the uppermost coal unit at section 8 (same as locality 172 of Barnes and Cobb, i959, p1s. 18, 19) was traced northeastward to section 9 by valking the line of outcrop. This work showed the coal unit correlaces with two coal teds, each 2 feet thick, that lie in tre interval 59-58 Feet below the top of losility 173 of Barnes and Codb (1959, pls. 13, 19). From section 9 a distinctive thin bed of tuff was similarly traced nortieastward to section 10 where the bed locally thiclens 
to 5.5 feet. A short distance upstrear from this location, the northwestdippirg tuff bed is covered by alluviua in the narron viliey of Fox creek. Correlation between sections 10 and 7 (pl. 1) is based mainly on a very impure coal bed, about a foot thick, and partiy on the stratigraphic position cf the coal in relation to the turif bed in the bottom of the valley.

The Sterling Ecrmation consists mainly of sandstore and silistone, but it inciudes snale, claystone, and many coal beds (pl, 1), The total thickness approximates 3,000 Eeet. Encept for the upper gart (section 7), rocks of the steriing closely reseable thcse of the Beluga, The domirant color is wedium gray, although lishter and darker shades of gray are fairly common. Yany beds in the upper 500 feet are medium dark bluish gray. Ironstaining is widespread.

The sandstone is chiefly piaty to very thin bedded, partly cross bedded, friable, very fine to fine grained, silty, and partly clayey. In the upper part of the formacion ( $\operatorname{sections} 9,10,7$ ), wuch of the sandstone is obscurely bedded, cross bedding is less common, and beds of fineto coarse-grained sandstone ar a more numerous. Many of the sandstone bodies probably are channel deposits; good examples include the basal sandstones of the scerling in sections 4 and L5. The siltstore is cbscurely bedied to platy bedded, generally clayey, and partly sandy. Much of the shaie and claystone are also obscureiy bedded to poor platy bedded and silty. Thin beds of dark-gray to black carbonaceous siale generally occur close to or within coal becis. Ironstone nciules are found in rany bads of the clastic rocks. The lower part of the forwation, 
nearly 500 jeet thick, includes several thin limy concretionary zones in beds of siltstone or shale. A thin liny siltstone bed occurs about 250 feet below the top of the starling.

Pyroclastic detritus is incorporated in many of the strata in the middle and upper parts of the sterling Formation. The detritus, generaily of sand size or smailer, includes crystal iragments of plagioclase, devitrified fumice and glass (?), volcaric ash, and tuff. it least one thin tuif bed in the upper part is a good marker bed local1y. It was used to correlate seccions 9 and 10 (p1. 1).

Coal in the Sterling Eormation, except for the upper part, closey resembles that in the upper part of the 3eluga. Numerous coal beds locally are 3 to 5.5 Eeet thick, including partings. The upper 580 feet of the Sterling includes only a fev impure coal beds that, with partings, are as much as 1.1 feet thick. Coal in the formation is hard, tough, and more resistant to weathering than the other rocks. it many places the thicker coals support waterfalls. Many beds weather platy and show woody textures. Flattened coalified logs are atundant, and stumps are present in some beds. Parts of many coal beds appear bony, impure, or shaly. No amber fragments vere found. Partings of shale or siltstone are common, and many of the partings contain fragtents of probable pyroclastic origin.

Fossils in the Steriing Formation include leaf impressions, other carbonaceous plant fragments uf widely varying size, and palynomorphs. The leaf ingressions were fcund in a relatively few beds near tne base (secticns 4,5 ) and in the upper part (sections 6, 8, 7). Plant fragments 
are generally present in the shale and siltstone and are found in much of the sandstone. In scme beds the fragments appear to be in growth position, and in ocher beds the orientation sppears random. The palynomorph taxa are listed in tables 2-4. Many of the taxa occur erratically in the Sterling. The few specimens of Carya (?) in section 4 may be redeposited, and the specimens of Ilex, Carya, and Tilia in sections 12,11 , and 6 probably are redeposited. The assemblage in sections 12-7 appears to be an upward continuation of the assemblages in sections $1 b-5$ and Li8-L6.

\section{Stratigraphic sections}

Detailed descriptions of the Beluga ind Sterling Fomations of the Kenai Group are jiven starting on page 27 . These are prisarily field descriptions supplemented by brịef nicroscopic study of representative samples. In the descriptions, the palynological sample numbers imnediately follow the rock type that was sampled. 


\section{References cited}

Adkison, W. L., and Neman, K. R., 1973, Lithologic characteristics and palynology of Upper Cretaceous and Tertiary rocks in the Deep Creek Unit well, Kenai Peninsula, Alaska: U.S. Geol. Survey open-íile report, $2710 ., 1 \mathrm{pl}$

Adkison, W. L., Kelley, J. S., and Newman, K. R., 1975, Lithology and palynology of Tertiary roc's exposed near Capps Glacier and along Chuitna River, Tyonek quadrangle, southern Alaska: U.S. Geol. Survey open-ille report $75-21,58$ p., 1 gi.

Barnes, F. F., and Cobb, E. H., 1959, Geology and coal resources of the Homer district, Kenai coal Eield, Alaska: U.S. Geol. Survey BulI. $1058-F$, P. $217-260^{\circ}$

Beikman, H. M., compiler, 1974, Preliminary geologic map of the soutieast quadrant of Alaska: U.S. Geol. Survey Map MF 612.

Caiderwood, K. H, and Eackler, w. C., 1972, Proposed stratigraphic nomenclature for Kenai Group, Cuok Inlet basin, Alaska: 3n. Assoc. Petroleum Ceologists Bul1., v. 56, no. 4, p. 739-754.

Dall, W. H., and Harris, G. D., 1892, Correlation papers -- Neocene: U.S. Geo1. Survey Bul1. 84,349 p.

Goddard, E. $\therefore$, shm, and others, 1948, Rock-color chart: Washirgton, D.C., Nat1. Research Ccuncil, repr. Geo1. Soc, America, 1963. Hartman, D. C., Desse1, G. H., Ac Gee, D. Lo, 1972, Preliwinary report on stratigraphy o: Nenai Group, upper Cook Inlet, Alashà Alaska Div. of Ceol. Survey, Dept. Natural Res. Spec. Rept. No. 5, 4 p., $11 \mathrm{pl}$. 
Kirschner, C. E., and Lyon, C. A., 1973 , Stracigraphic and tectonic development of Cook Inlet petroleum province, in Arctic Geology: Tulsa, Okla., Am. Assoc. Petroleum Geologists Yem. 19, p. 396-407.

Wolfe, J. A., Jcpkins, D. M., and Leopold,. E. B., 1956, Tertiary stratigraphy and paleobotany of the Cook Inlet region, Aldska: U.S. Geol. Survey Prof. Paper 398-A, $29 \mathrm{p}$. 
Measured section la

Location: Sea-cliff and hillside exposures along shore of Kachemak Bay from mouth of Diamond Creek, SiN corner SE 1/4 iin $1 / 4 \mathrm{sec}$. 8, T. 6 S., R. 14 W., northiwes tward to a point about 0.7 mile scutheast of mouth of Travers Creek (Yutnala Guich), ith 1/4 SE 1/4 HW 1/4 sec. 27, T. 5 S., R. 15 iv., Seldovia C-5 quadrangle. This measured section inciudes localities 77-87 of Barnes and Cobb (1959, pl. 18).

Note: Measured section 1 a probably is separated from section ib by a fault of unknown but possidly large displacement.

Feet

Tertiary rocks -- Kenai Group, Beluga Formation (lower part)

Shale, dark-gray, fissile, carbonaceous; abundant plant fragrents; ugper contace mostiy covered jy s?umped materiàl -

Coal, bony in lower half; blocky- and platy-weathering in upper haif--1.

Siltstone, medium-gray, hard, touch, not limy, clayey; upper $1 \mathrm{ft}$. concretionary and iron-stained with abundant piant fragments; pooriy exposed--.--.-.-.-.-.--- 5.

Coal, bony; inciudes near middle a 0.2-ft. parting of medium-brown pyroclastic(?) siltstone with abundant carónaceous iaminations-_.....

Siltstone and interbedded shaie; siltstone, mediumgray, partly iron-stained, slabby - to unevenweathering, obscurely becaed, clayey; no piant fragments seen; includes a 0.5-ft. sad of mediumgray iron-stained fine-grained suoangular sandstone about $4.5 \mathrm{ft}$. áove base; unit becomes less clayey in upper $3 \mathrm{ft.}$.

Coal, bony; includes black to dark-brownish-gray carbonaceous snale; upper 0.3 ft mainiy carbonaceous

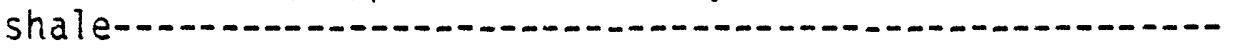

Siltstone and interbedded sandstone; siltstore, mediumgray, iron-stained, clayey; abuncant niant fragments; becomes sandy aoove lower 1 ft.; includes limy concretions up to $1 \mathrm{ft}$. thick; a $1.5-\mathrm{ft}$. medium-gray finegrained sandstone bed $5.6 \mathrm{ft}$. above base; lower contact gradational 


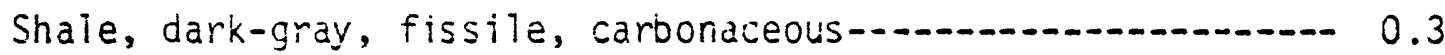

Shaie, medium-brown to dark-brownish-gray, sandy; abundant coaiy plant fragments; pyrcciastic(?) feldspar

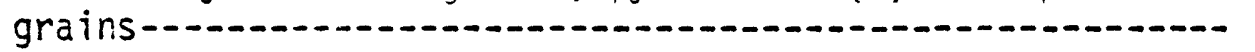

Coal, bony; interbedded with black carbonaceous snale; includes a carbonaceous shaie bed at base-.-.-.-.-.-.-.-.- 0.4

Shale, medium-gray, hackly-weathering (small pieces), obscurely beddsd, sity; no piant fragments; ? ower

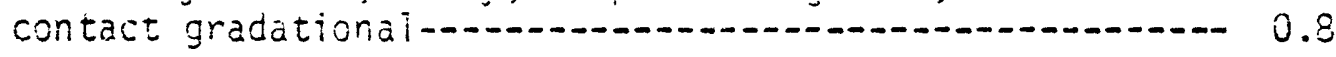

Sands tone, reaium-gray, slabby-weathering, obscureiy bedded, fine-grained, subangular: no piant frag-

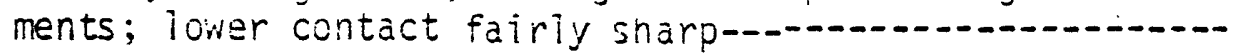

Shale, redium-gray, slightly iror-stained, slabby- to uneven-weatnering, obscurely bedced; carbonaceous woody

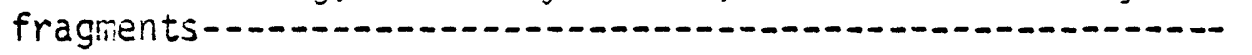

Ironstone, i ight-brownish-gray, nodular; abundant plant fragments-..-..-

Shale, dark-brownish-gray, sandy, carbonaceous; abundant

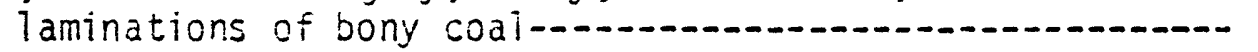

0.4

Sandstone, redium-gray, slabby-weathering, very fine grained, subangular, silty, clayey; includes an ironrich zone $1 \mathrm{ft}$. below top-1..-

Siltstone, medium-gray, partly iron-stained, hackiyweathering, soft, very clayey; no plant fragments seen; contains interbeds of silty shale; includes a 0.i-ft. bed of bony coai with abundant woody structure

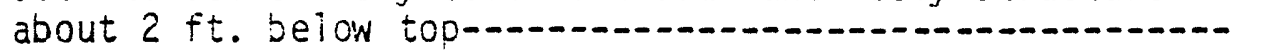

Coal, platy-weathering; interbedded with dark-brownishgray carbonaceous shaie and bony coal-_................. 0.4

Shale, medium-grav, hackly-weathering, silty in part; breaks to smail pieces-_.........

Siltstone, medium-gray, slabby-weathering, thin-bedded, cross-bedded, ciayey; icwer contact gradationai-....-.-.-. 4.

Shale, medium-gray, partly slasby-ieathering, thin-bedded, silty in part; includes a few tn in caroonaceous lami-

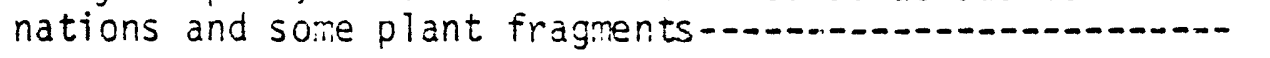


Shale, dark-brownish-gray, platy-weathering; abundant plant fragments; interbedded with thin bony coal

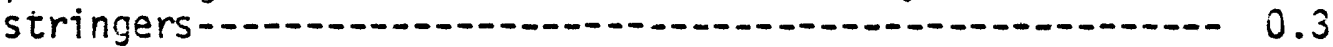

Sandstone, medium-gray, slabby-weathering, obscurely bedded, fine- to nedium-grained, subangular, clayey; no $p$ !ant fragments; grades upward to medium-gray sandy siltstone and siity shaie in upper $1.5 \mathrm{ft} . \cdots-.-.-{ }_{4} 4$.

Coal, bony in basal $0.5 \mathrm{ft}$. and upper $0.4 \mathrm{ft}$.; includes a $0.3-\mathrm{ft}$. medium-gray shale varting $0.3 \mathrm{ft}$. above base; a 0.65-0.9-ft. medium-gray snale parting 1.1 it. above base; a 0.1-ft. deeply weatnered brown shale parting 0.4 ft. below top; some very thin lenticular medium-brown pyrociastic(?) partings near middile-....-.-- 3.5

Shale, dark-gray, partly iron-stained, nackly-weathering; basal $0.5 \mathrm{ft}$. deesly weatrered; piant frigrents common; includes carbondceous and coaiy stringers; a 1-ft. medium-gray very fine grained sancs sone oed

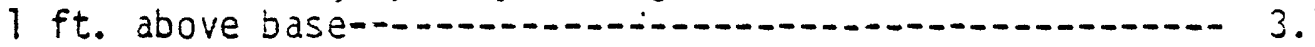

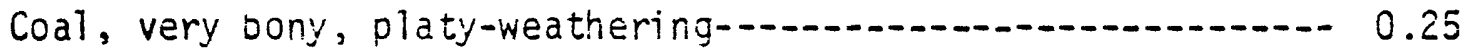

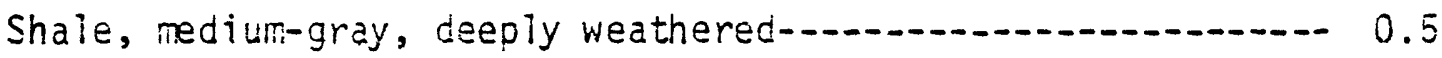

Coal, blocky, very oony in basal $0.2 \mathrm{ft}$; includes a ienticular 0.?-ft. parting of medium-brown silts tone $1.1 \mathrm{ft}$. above sase and 2 similar lenticular partings in upper $0.5 \mathrm{ft.} . \ldots$

Siltstone, medium-gray, light-gray hackly- to unevenweathering, obscurely bedded, clayey; many curbonaceous plant fragments; lover contact probajly gradational-

Sandstone, medium-gray, partly iron-stained, thin-slabbjweathering, obscurely becded, very friabie, miediumgrained, scattered coarse grains, subangular, sichtly clayey; becomes very fine grained and clajey in upper

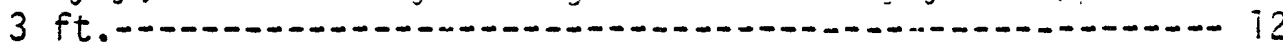

Coal, bony; includes a $0.1-\mathrm{ft}$. parting of nedium-brown

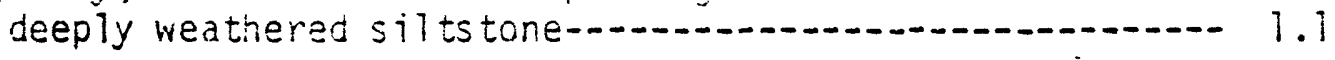

Shale $(1 P-112)^{*}$, redium-gray; includes scattered rarbonaceous stringers, plant fragments and coal stringers; contains large coalified wood fragmerts at an angle to bedding-_. co 
Shale, medium-gray, hackly-weathering, silty; some plant

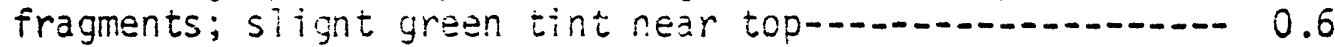

Sandstone, mediun-gray, iocally iron-stained, fine-grained, subangular, clayey; iocally includes nard probabiy iron-rich concreticrary bodies ue to $0.5 \mathrm{ft}$. thick;

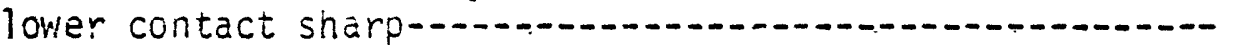

Siltstone, mecium-gray, hackly- to sub-platy-weathering, obscurely bedded, ciayey; few carbonaceous plant frag!rerits; includes tnin stringers of dark-gray carbonaceous shale near nidcile and top; !ower con-

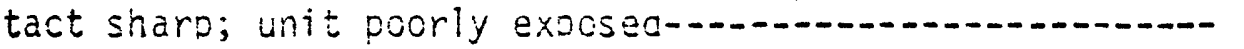

Shale, brownish-gray, poor platy-bedded, slightly silty; some cartonaceous piant fragments; top 0.1 ft.bone coal

Siltstone, dark-orownish-gray, finely sandy, cl zyey, pyroclastic(?) grains; includes a few thin coal

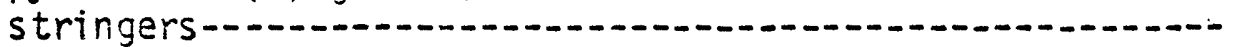

Coal, bony-1.-1.

Sandstone, redium-gray, Dartly iron-stained, obscurely bedded, fine-grainea, subangular, clayey; lower

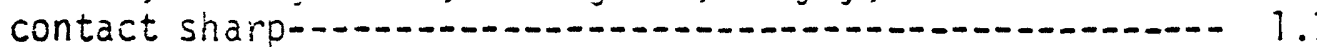

Shale, medium-gray, obscurely bedded, silty; includes at base a 0.1-ft. dark-browrish-gray silts tone with carbonaceous fragments; at $0.5 \mathrm{ft}$. above base a 0.05 ft. black carbonaceous snaie; at $0.8 \mathrm{ft}$. above base a $0.3-\mathrm{ft}$. ironstone bed with commion plant fragments-...-- 3.4

Sandstore, nedium-gray, localiy iron-staired in lower $12 \mathrm{ft}$. , thin-slaboy-weathering, obscurely bedded at base, very friable, mediun- to very coarse grained (basal $0.3 \mathrm{ft}$.) grading uswarc to fine-crained near tos, subangular to subrounded, ciayey; iriciudes a few redium-gray ironstained platy-weathering si? sstone becs in a j.5-ft. zone $3.8 \mathrm{ft}$. above oase; 3 bromn-gray to olive-gray siltstone ienses or beds $8 . \overline{3}$ ft. -9 ft. above base; a concretionaly limy cross-bedded ironstone-bearing zone 12-16 ft. above base; dominantly well soried and even textured rear 
Siltstone, medium-gray, iron-staired, laminated to thinbedded, very finely sandy, clayey; few plant fragments-_._- 0.3

Shale, medium- to dark-gray, desply weathered; abundant plant fraginents-... 0.4

Ironstone, medium-gray, iron-stained, nodular-weathering;

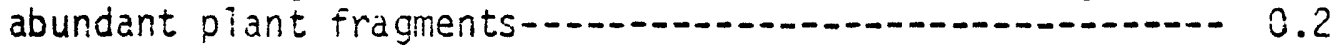

Claystone, light-brown, shard-1ike-weathering, obscurely bedded; plastic when wet; discincrive-................... 0.3

Coal, blocky; includes at least j dark'k-brownish-gray iron-stained pyroclastic(?) siitsione partings up

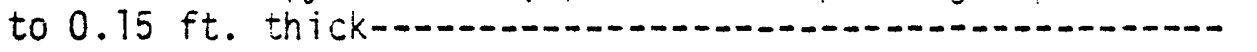

Shale, medium-gray, hackly-iveathering, obscurely beddad, silty; some carbonaceous plant fragnents; inciudes a 0.1-ft. biack carocraceous shaie jed ajout 2.5 ft. above base; a $0.7-f t$. Ded oi medium-gray finegrained sandstone aoout $2.9 \mathrm{ft}$. above base; at 4.8 ft. above base a $0.2-7 t$. bed of medium-gray siitstone overlain by $0.3 \mathrm{ft}$. of black carbonaceous shale and bony coai; about 0.8-ft. bed of mediumgray fine-grained sancstone 0.0 ft. below top-...........- 9.7

Coal, bony; interbedded with carbonaceous shale; includes thin brown pyroclastic siltstone partings rear top-...-.- 0.3

Siltstone, medium-gray, partly iron-stained, cbscurely bedded, clayey; common plant fragments-................... 6.5

Coal, blocky, appears bony in large part; inciudes a 0.25 ft. parting of brownisn-gray sancy pyroclastic sittstone about $0.5 \mathrm{ft}$. acove Dase; a $0.25-\mathrm{ft}$. parting of dark-gray carbonaceous shale with coal stringers 1.3 ft. above base; usper part of unit contains 3 mediumbrown lenticular siltstore partings up to $0 . i \mathrm{ft}$. thick; top $0.4 \mathrm{ft}$. of coal bed very wony-................ 2.8

Sandstone, mediuri-gray, slabby-weatherng, obscurely bedded, rejium-grained, subangular, si ightly silty; becomes si? tstore in top ore-nal f; inciudes ironstone coricretions uo to $0.4 \mathrm{ft}$. thick in upper part; lower contact snarp-a.-. 
Siltstone, medium-gray, siabby - to uneven-weathering,

thin-bedied, obscurely' cross-bedded, ciayey, very

clayey in upper part; faw plant fragments; inciudes

a $2 \mathrm{ft}$. medium-gray concretionary nard i imy siltstone with abundant plart remains in upper part;

lower contact gradationai-... 3.

Sandstone, medium-gray, slabby-weathering, obscurely

bedded, medium-grained, subangular to subrounded,

slightly clayey; few carbonaceous piant fragments

Silts tone, redium-gray, light-gray-wea-hering to

horizontal oi ates up to j.l it. thick, laminated,

clayey; no plant fragnents seen-1... 2.

Shale, dark-brcwnish-gray to black, carbonaceous; basal

$0.2 \mathrm{ft}$. mainiy dark-brcwnish-gray siltstone-......... 1.5

Siltstone, mediun-gray, partiy i igntly iron-stained, hackiy - to siaboy-weatnering, obscurely bedded, clayey; includes at base a medium-gray nard limy siltstone concretion zone, wip to ? it. thick, with abundant $p l a n t$ fragments and leaf impressions; 3 beds of medium-gray slabby-weathering very tinin bedded fire-grained clayey sands tore about $1 \mathrm{ft}$. thick separated by about 0.3-it. jeds of silts tone;

very small ironstones in the upper $1 \mathrm{ft}$. of unit....... 11.

Shale, inedium-gray, 1ight-brown-weathering, iron-stained, carbonaceous; abundant plant fraginents

siltstone, medium-gray, slabby- to irreqular hacklyweathering, obscurely bedded, clayey; scattered small coaly fragments; lower contact gradational-....... 4.

Sandstone, medium-gray, locaily lightly iron-stained, siabby-weatnering, obscurely thin-bedded, very

fine grained, subangular, silty, clayey-...... 5 .

Shale, medium-jark-gray, fissile; abundant coaly plant fragments - 0.3

Shale, medium-gray; scattered carbonaceous fragments-....... 0.7

Coal, bony- 0.6

Shale, medium-dark-gray, partly iron-stained, platy- to

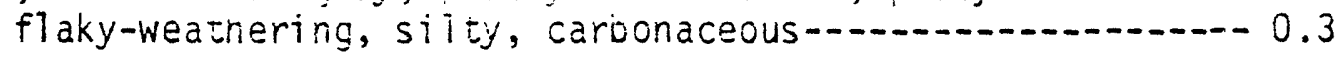




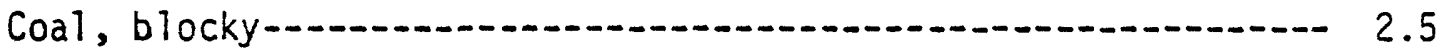

Shale (1P-94)*, medium-gray, hackly-weàthering, slightly plastic; scme carbonaceous plant fragments--.-.-.-.-.--0.8

Coal, platy-weathering, bony-a-n 0.4

Sil tstone, medium-gray', partly iron-stained, uneven- to

slabby-weathering, obsclirely thin-bedded; includes

local concretionary bodies up to $2 \mathrm{ft}$. trick; some

interbeds of medium-gray silty snale; upper $1 \mathrm{ft}$.

harder and more iron-stained than lower part and

contains common coalified plant iragments-----.--.---.--- 0.3

Coal, platy-weathering, bony; interbected with dark-gray

fissile carbonaceous snale wi th adundant piant frag-

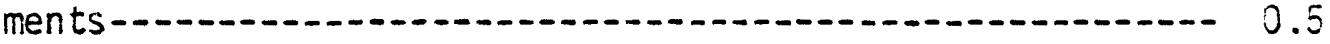

Siltstone, medi um-gray, uneven siabby-weathering, thinbedded, soft, very ciayey; plant fragments; lower contact gradational-_...-... 1.5

Sandstone, medium-gray, slabby-weathering, thin-bedded, fine-grained, subanguiar, silty, clayey; includes stringers of carbonaceous materiai; lower contact gradationa?

Siltstone, medium:-gray, slabby- to blocky-weathering, thin-bedded, soft, very clayey, finely sandy-..........-. 1.

Siltstone, medium-dark-gray, partly iron-stained, obscureiy bedded, sandy, carbonaceous; some plant fragments; includes sandy silts tone concretions--.--.---.--- $i$.

Sandstone, medium-gray, slabby-weathering, massiveappearing, fine-grained, subanguiar, silty, ciayey;

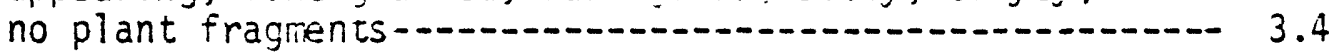

Siltstone, medium-gray, partly iron-stained, hacklyweathering, rassive-appearing; includes $0.3-t i$. bed of medium-gray slacby-weathering fine-grained sand-

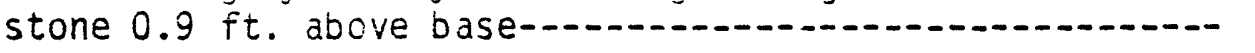


Coal, blocky; upper $1 \mathrm{ft}$. fissile to platy-weathering and bony; includes 0.2-ft. carbonaceous shale parting $1 \mathrm{ft}$. above base; lenticular parting, up to $0.2 \mathrm{ft}$. thick, of medium-brown siltstone containing scattered fine-grained spheroids of hydrous iron oxide $1.5 \mathrm{ft}$. below top; lower contact sharp-...........-. 5 .

Sandstone, medium-gray, good slaboy-weathering, thinbedded, cross-bedded, ?aminated wi th carbonaceous plant material, 'ery fine grained, silty, clayey; some coaly : wood fragments; includes at oase concretionary hard limy siltstone with many plant fragments

Siltstone, medium-gray, partly iron-stained, hacklyto slabby-wathering, obscureiy bedded, soft, very clayey; incluses $0 . \overline{3}-\mathrm{ft}$. bony coal $2 \mathrm{ft}$. below top-...--- 5.1

Coal, blocky- to platy-weathering, joryy; includes at 0.3 ft. above oase a 0.4-ft. barsing of medium-gray soft slightly piastic (when wet) clayey snale with coaly wood fragrents; at $1.2 \mathrm{ft}$. above base a $0.7-\mathrm{ft}$. bed of medium-dark-gray fissile carbcnaceous shale with

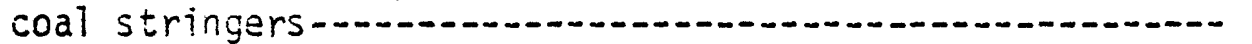

Siltstone, medium-gray, hackly-weathering, obscurely bedded, so ft, clayey; no piant fragments; includes ironstone noduies up to $0.3 \mathrm{ft}$. thick about $\mathrm{l} \mathrm{ft}$.

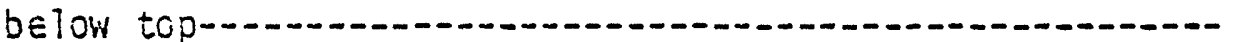

Sandstone, medium-gray, slabby-weathering, cbscurely bedded, soft to weil indurated, fine- to mediumgrained, subanguiar, silty, clayey; includes hard limy concretions locally in lower $6 \mathrm{ft} . ;$ large coaly

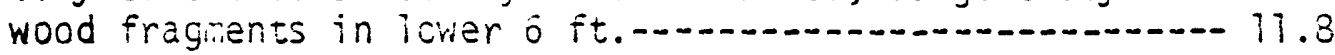

Coal, blocky- and platy-weathering; includes near middle 0.2-ft. parting of medium-dark-gray fissile carbonaceous shale with many piant fragments; near top $0.2-\mathrm{ft}$. parting of medium-brown fine-grained pyroclastic sandstone with abundant coa! stringers and

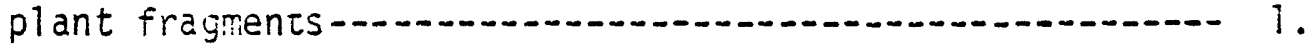

Siltstone, medium-gray, hackly- to slabby-weathering, obscureiy bedded, clayey; no plant fragments-............- 3.

Shale, dark-gray, fissile, carbonaceous; some large woody plant fragments; includes iriterbeds of bony coal-........ 0.4 
Siltstone, medium-gray, partly iron-stained, slabbyweathering, very thin bedded, cross-bedded, partiy very finely sandy, claysy; includes at oase a 1.5ft. concretionary nard iiny silts tone with common plant fragments-a.... 2

Siltstone, medium-gray, slaboj-wathering, very thin bedded, clayey: interbedded with meaium-gray slabbyweathering very thin beaded cross-sedced very fine grained sandstone; includes $3-f t$. ved of mediumgray $s$ ? abby-weathering very silty srale at base-........- 11.5

Sands tone, redium-gray, siabby-weatnering, trin-bedded, cross-bedded, fine-grained, subangdiar, siity, clayey;

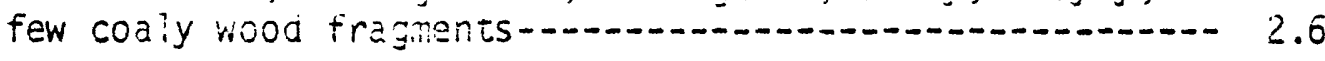

Sandstone, medium-gray, obscureiy bedded, soft, finegrained, silty, cijyel; becomes medium-gray hacklyweathering thin-bedied cross-oedded silis tone in upper half-a-n 4.1

Shale, mediun-gray, hackly-weathering, cbscurely bedded, very silty; some carconaceous plant frargients-..........- 0.7

Sandstone, nedium-gray, slabby-weathering, coscurely bedded, fine- to medium-graired, subangular, silty, clayey-1.-1-

Shale, medium-gray, hackly-weathering, obscurely bedded, very silty; some cartonaceous plant fragments-..........-.

Sandstone, medium-gray, slabby-weathering, obscurely bedded, fine- to redium-grained, subangular, silty, cl ayey-1.-...-

Shale, medium-gray, hackiy-weatnering, obscurely bedded, very silty; lower $0.4 \mathrm{ft}$. hard liny concretionary shàe with abundant plant fragments; lower contact sharp-......

Coal, blocky, bony at base and in uojer $0.2 \mathrm{ft.;}$ contains scattered fragrents of arber; includes $0.2-\mathrm{ft}$. parting of medium-dark-gray to brownisn-gray platy-weathering carbonaceous silty shale at $0.5 \mathrm{ft}$. above base; partings up to $0.05 \mathrm{ft}$. thick of redium-brown pyroclastic claystone, siltstone, and black carbonaceous silty shale in $0.3-\mathrm{ft}$. zore $0.8 \mathrm{ft}$, below top; iower contact sharp-1..- 
Sandstone, medium-gray, slabby-weathering, th in-bedded, locally prominentiy cross-bedded, friable, fine- to medium-grained, subangular, silty, clayey; near middle becomes iron-s tained, hard, limy, and concretionary (concretions up to $0.8 \mathrm{ft}$. thick by 2

ft. long); lower contact fairly sharp-a-n 2.9

Siltstone, redium-gray, partly iron-stained, hackly - to slabby-weathering, thin-beddec, clayey; fisw scattered large coal fragments randomiy criented; inciudes $0.2-$ ft. bed near top of medilum-dark-gray izminated to fissile carbonaceous shaie wit abundan: smail plant fragments-1 2.3

Coai, platy, bony; upper part becomes mediun-dark-gray platy carbonaceous shaie; iciver contacs wavy-...-.-.-.--- 0.0

Shale, mediun-dari-gray: partly iron-stained, biocky- to hackly-weathering, thin-bedaed, siity; aburdant plant fragments-a-n $0: 6$

Shale, black, carbonaceous; includes bony coal-..............- 0.2

Sandstone, medium-gray, partly iron-stained, slabbyweathering, cross-bedded, limy, very fine to finegrained, silty, ciayej; becomes more silty and weathers blocky to hackly with some ircn-staining in upper 0.8 ft.; includes local concentrations of iarge coaly plant fragments; interiaminations of carbonaceous material in iower $1 \mathrm{ft.}$

Siltstone, medium-gray, light-gray slabby-weathering, obscurely bedided, subconchoidal-fracturing; some large plant fragments; incluces iine-grained sand-

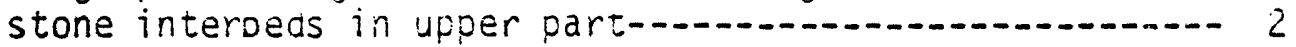

Shale, medium-1ight- to medium-gray (wet), hackly- to slabby-weathering, obscurely thin-bedded, mostly carbonaceous, siightiy silty; necores very carbonaceous in icker rajf: incluides a $i$ oase 0.i-ft. bed of bony coal; at too 0.25-ft. zone of bony coal and interbedded carbonaceous shaie with stringers of medium-brown pyrociastic sil ts tone-....................... 1.3

Siltstone, redium-gray, partly iron-stairied, ledge-forming (single beo), liny, clayey; abundant plant fragments

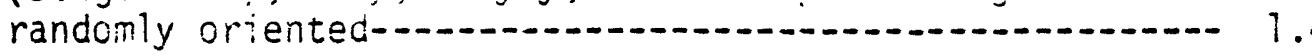


Shate, medium-gray, obscurely bedded; includes $0.1-\mathrm{ft}$. bed of bony coal or coaiy carbonaceous snale 0.4

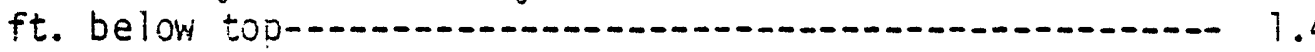

Sandstone, redium-gray, s? abby-weathering, massiveappearing, frooably thir-bedced, fine-grained (base) grading upivara to very fine grained (top), sibangular, silty, clayey; caroonaceols piant iragments; includes i-ft. Ded of mediur-gray silty shale about $3 \mathrm{ft}$. above base; scatzered ironstone concretions up to $0.1 \mathrm{ft}$. in dianeter in midile; 0.5-ft. bed of medium-gray hackly-weathering silty

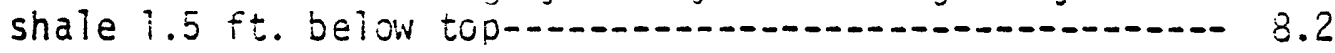

Coal and interbedded shale; coal beds up to $0.7 \mathrm{ft}$. thick; shale, medium- to dark-gray, iron-stained, obscurely to platy-cEdced, partly caroonaceous; piant fossiis; $0.1-f t$. lencicular parting of mecium- to lignt-brownweathering siltstone (oyroclastic?); $0 . \bar{s}-\mathrm{ft}$. lense of brownish-gray to medium-gray hard nonlimy ironstone with abuncant plant fragments $1 \mathrm{ft}$. below top-..-.- 5 .

Sandstone, medium-gray, partiy iron-stained, siabbyweathering, coscureiy thin-bedded, friable, finegrained; becomes very fine grained in upper part; includes coaly wood fragments in lower part-............. 2.6

Coal, blocky; bony in basal $0.3 \mathrm{ft}$. and $0.2-\mathrm{ft}$. bea $1.7 \mathrm{ft}$. above base; upper $2.2 \mathrm{ft}$. includes interbedded medium-dark - to dark-gray partly carbonaceous shale, with plart fragments and ccal stringers, and 4 bony coal beds up to $0.2 \mathrm{ft}$. thick-................ 4.1

Sandistore, medium-gray, slabby-weathering, obscurely thinbedided and cross-becasd, massive-appearing, partiy limy, even-textured, medim- to very fine grained, subangular, clayey, silty; becomes finer grained toward top and grades to sandy clayey siltstone in top $1 \mathrm{ft}$; ; scatiered coal fragrents; abundant carbonaceous material rear middie; includes limy concretions in lower $3 \mathrm{ft}$

Shale, medium-dark-gray, olaty- to very thin bedded; basal 0.6 it. carbonaceous with bony coal stringers in upper $0.2 \mathrm{ft}$.; includes $0.5-\mathrm{ft}$. coa? bed $1.35 \mathrm{ft}$. above base; a limy concretionary siltstone with abundant large plant fragments in upper $0.8 \mathrm{ft. \cdots ...-.-.-2.65}$ 
Sands tone, medium-gray, slabby-weathering, thin-bedded, indistinctly cross-bedded, fine- to very fine grained, silty, clayey, micaceous; few carbonaceous plant fragments; grades to medium-gray sandy clayey siltstone with weathering characteristics of shale in upper 2 ft.

Silts tone, medium-gray, hackly-weathering, massiveappearing to obscureiy laminated (mostiy laminated in basai part), very clayey; grades to medium-gray shale in upper $3 \mathrm{ft}$.; includes 1 ight-brownisn-gray ironstone nodules up to $0.2 \mathrm{ft}$. in diameter about $\overline{4} .5 \mathrm{ft}$. above base; 0.6-ft. ironstone zone 0.3 ft. bejow top-.........- 6.6

Sandstone, medium-light-gray, slabby- to massive-weathering, obscurely thin bediced, fine-grained, silty, ciayey; grades upward to siltstone; iower contact sharp-........- 4.3

Sandstone, redium-1ight-gray, 1 ight-brownish-grayweathering, inin-iedded, prominently festoon crossbedced, friasle to moderately indurated, localiy limy, medium-grained, localiy coarsely sanay to peobly, subangular, silty; contains large coal fragments; includes common iight-brown to light-olive-brown clay grains (volcanic?); locally forms limy concretionary bodies up to $3.7 \times 15 \mathrm{ft}$.; forms massive rounded ledges -..-1.-1

Coal; includes $0.1-f t$. parting of brownish-black very carbonaceous shaie (almost bone coal) $0.8 \mathrm{ft}$. above base; 0.3-it. parting of brownish-gray silts tone 1.3 ft. above base; 0.3-ft. parting of dark-gray carbonaceous shale $0.35 \mathrm{ft}$. below top; few bony coal partings up to $0.1 \mathrm{ft}$. thick-1.-.

Shale $(1 \mathrm{P}-72) *$, dark-gray to black, piaty-bedded, plastic when wet in upper $0.2 \mathrm{ft}$. ; some plant fragments; includes a $0.1-\mathrm{ft}$. coal bed $0.3 \mathrm{ft}$. above base-..-.-.....- 0.6

Shale, mediurn-light- to medium-gray (wer), iocaily ironstained, hackiy-weathering, massive, iccally limy, silty; few plant fragrents; inciudes at top 0.3-ft. bed of brownish-gray-weatnering nodular silitstore

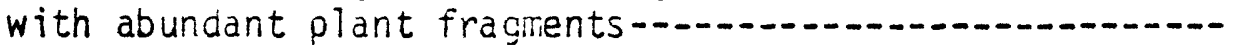


Coal, blocky, mostly bright; scattered white mediumgrained pyrociastic(?) particles; includes 2

lenticular partings, up to $0.05 \mathrm{ft}$. thick, of brown

siltstone rear middle; upper contact poorly exposed;

lower contact covered-_. 2.3

Note: Beginning a $\tau$ the exposure of the coal described above, near the center of the SW $1 / 4 \mathrm{sec} .6$, T. 6 S., R. $14 \mathrm{w}$. and extending northwest for nearly 2 miles, Pleistocene deposits cover the beiuga Formation discontinuousiy for distances as great as $1 / 2$ mile. These deposits may conceal a fauit in the Beluga near the coal exposure described above, but conclusive proof is lacking. The coal described jelow is Exposed along the beach near the west iine of sec. 36, T. 5 S., R. $15 \mathrm{w}$.

Coal, blocky, bright in part; basal $0.15 \mathrm{ft}$. dark-brownishgray sandy si? ts tone (1F-58) * with aduncant carconaceous material; includes 0.3-it. parting of carkgray to black platy-weathering caroonaceous shale $(1 \mathrm{p}-68) * 1.5 \mathrm{ft}$. adove Dase; lenticuiar partings, up to $0.1 \mathrm{ft}$. thick, of medium-brown platy-bedded very fine grained sands tone $1.4 \mathrm{ft}$. below top; upper contact covered by slumpy pleistocene sediments--

Sands tone, medilum-gray, slabby- to blocky-weathering, obscureiy thin-bedded, cross-bedded, very fine to medium-grained, subangular, silty, clayey; becomes very fine grained and more silty and clayey in upper half; locally iricludes limy concretions up to $3 \times 15$

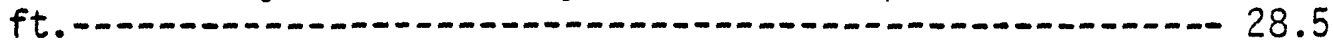

Coal, bony-1 0.3

Shale, dark-gray to black; abundant carbonaceols wood

fragments--.-1 0.6

Coal, woody; interlaminated with black platy-weathering fissile carbonaceous shale-1..- 0.4

Sands tone, medium-gray, slabby-weathering, thin-bedded, cross-bedued, very fine to fine-grained, subangular to subrounded, si ity, clayey; ablirdant smali carbo-

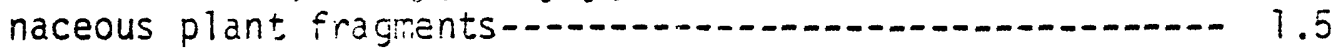

Shale, medium-gray, platy-bedded; abundant very thin coaly

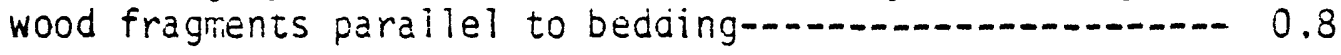


Shale, medium-gray, poor slabty-weathering, obscureiy bedded, clayey; abundant coaly plant fragments-.........- 2.1

Shale, dark-gray, fissile, carbonaceous; lower contact gradational--.-.-.-. 0.2

Coal, mostly biocky; includes few stringers of brown sandstone up to $0.01 \mathrm{ft}$. thick-1.8

Shale, dark-gray, fissile, caroonaceous; many plant fragments; includes near middle a $0.4-f t$. bed of brownish-gray concretionary siltstone with abundant plant fragments

Coal, platy at top and base; scattered white mediumgrained pyroclastic(?) particies; includes at 0.6 ft. above base a $0.4-i t$. parting of medium-brown very fine grained pyroclastic sandstone interbedded

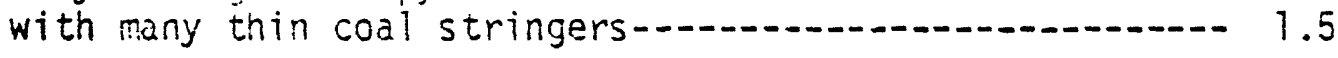

Note: A slump block or channel fill of Pleistocene deposits, possibiy $300 \mathrm{yd}$. wide, separates the rocks described above from those described beiow and may conceal a fault.

Coal; includes 1-ft. parting of medium-gray to palebrown pyroclastic(?) shale about $0.5 \mathrm{ft}$, above

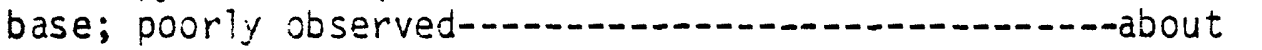

Sandstone, medium-gray, massive-appearing, mostly finegrained, locally medium-grained and coarse- to very coarse grained in basal $1 \mathrm{ft}$., subangular, silty, clayey; loca!ly forms limy concretions containing many large woody coal fragments; includes few carbonaceous shale stringers up to $0.1 \mathrm{ft}$. thick; upper half becomes medium-gray slabby-weathering massiveappearing siltstone ( $1 \mathrm{P}-63$-. from top $1 \mathrm{ft}$. of unit)*

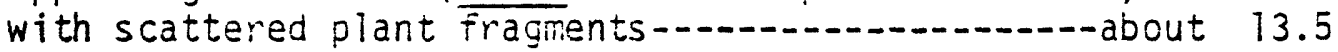

Coal, blocky; includes several medium-brown fine-grained pyroclastic sandstone partings, up to $0.1 \mathrm{ft}$. thick, in lower $1.5 \mathrm{ft}$. and upper $2 \mathrm{ft}$.; a $0.6-\mathrm{ft}$. parting of medium-grained siderite sphercids, altering to hydrous iron-oxide, in dark-gray clay miatrix at 1.5

ft. above base-_... 4.5

Claystone, medium-gray, hackiy-weathering; obscurely

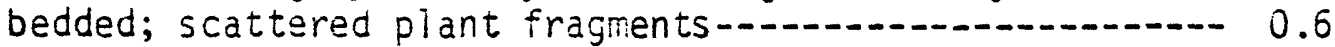


Siltstone, medium-gray, thin-bedded; some carbonaceous

plant fragments; lower contact gradational-................ 1.

Sandstone, medium-gray, slabby-weathering, very thin bedded, cross-bedded, soft, very fine to fine-grained, subangular, silty, clayey; includes few carbonaceous

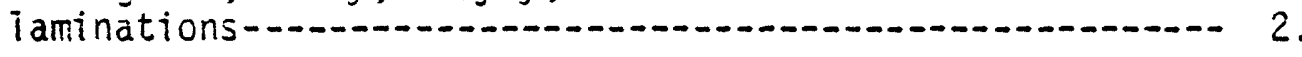

Shale, black, fissile, carbonaceous; includes coal stringers

0.4

Shale, medium-gray, slabby-weathering, very thin bedded; abundant plant fragments on bedding planes; lower

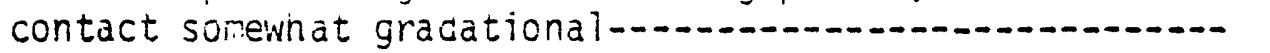

2.

Coal, mostly bony; forms beds up to $0.5 \mathrm{ft}$. thick; contains amber grains; includes numerous partings of dark-gray to brownish-gray fissile carbonaceous snale with aoundant woody coa! and smail plant fragments; a ienticuiar bed (up to $0.7 \mathrm{ft}$. thick) of brownish-uray very fine grained very ciayey sandstone with carbonaceous piant fragments near middle of unit; a 0.6-ft. bed of medium-1ight-gray hackly-weathering shale with scattered plant fragments near top--..-

3.

Shale (1P-59 -- from top $0.5 \mathrm{ft}$. of unit)*, medium-gray to brown, Dartiy iron-stained, hackly-weathering, obscurely cedded; brown and carbonaceous at top;

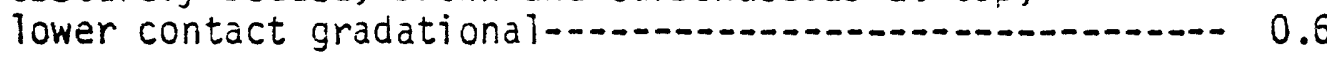

Sandstone, medium-gray, partly iron-stained, slabbyweathering, opscurely bedded, probably thin bedded, very fine grained, silty, clayey; no plant fragments seen-1..- 2

Shale, medilim-dark - to dark-gray (wet), carbonaceous; lower contact gradational-1.-1 0.3

Shale, medium-gray, locally iron-stained, hackiyweathering, ooscureiy bedded, silty, sligntiy plastic (wet) -

Siltstone, medium-light- to medium-gray (wet), slabbyweathering, obscurely thin-bedded, clayey-.................. 3.

Siltstone, redium-light- to medium-gray (wet), locally iron-stained, nackly-weathering, obscurely bedded, clayey; no carbonaceous fragments seen-...............-... 1.3

*Palynological sample 
Sandstone, medium-gray, hackly- to slabby-weathering, massive-appearing, probably very thin bedded, very fine to fine-grained, silty, clayey; few carbonaceous plant fragments; iower contact gradational-.... 4.

Shale, medium-gray, iocally iron-stained (on fractures), hackly-weathering, obscurely bedded-_..... 2 .

Coal, fissile, bony; almost a carbonaceous shale; lower contact gradational-a. 0.2

Clay, medium-gray, cbscurely bedded, plastic; small randomly oriented carbonaceous plant fragments-........ 0.4

Sandstone, medilim-gray (wet), locally iron-stained, poor slabby-weatnering, mostly soft, fine-grained, subangular; many piant fragments (probably roots); iron-stained zone in middle contains concretions up to $0.5 \mathrm{ft}$. thick- 2.

Shale, dark-gray, fissile, carbonaceous; some woody plant fragments-_. 0.3

Shale, medium-light- to medium-gray (wet), hackly-weathering, obscurely bedded; some carbonaceous fragments-....- 2.6

Sandstone, medium-gray (wet), partly iron-stained, slabbyweathering, probabiy thin-bedded, very fine grained, silty, clayey; some carbonaceous piant fragments;

lower contact sharp-a

Shale, black to brownish-gray, laminated, carbonaceous; inciudes coal stringers; grades in upper part to blocky bony coal; lower contact gradational-_........ 1.2

Siltstone, medium-gray (wet), blocky-weathering, locally obscurely iaminated, soit, clayey; includes biack coaly shale, $0.1 \mathrm{ft}$. thick, at $0.5 \mathrm{ft}$. above base (probably pinches out laterally); clayey zone at $3.8 \mathrm{ft}$. above base containing nonlimy ironstone concretions up to $0.3 \mathrm{ft}$. thick-... 6.5

Siltstone, medium-dark-gray, obscurely bedded, conchoidalfracturing, hard, dense, limv, very finely sanay; few carbonaceous plant fragments 
Sandstone, medium-gray, obscurely thin-bedded, finegrained, very silty, clayey, locally partiy concretionary; interbedded with siltstone and shale; incluaes at base $0.1-\mathrm{ft}$. bed of black bony carbonaceous shale overlain by $2-f t$. bed of medium-gray

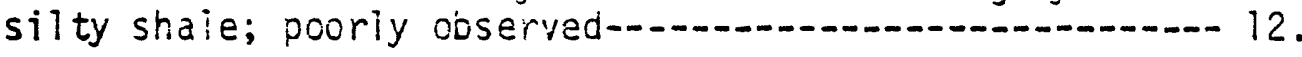

Sandstone, medium-gray, slabby-weathering, massive,

fine- to very fine grained, subangular, clayey;

very clayey and hackly-weathering in upper half-..-.--.-- 3.7

Shale, medium- to medium-dark-gray (wet), silty; carbonaceous in upper part- 1.5

Siltstone, medium-gray, slabby-weathering, massive, finely sanay, clayey; abundant smali carbonacecus iragments in lower $1 \mathrm{ft.}$

Coal, blocky; includes several stringers of medium-brown pyroclastic si? tstone; lateraily unit changes to medium-dark-gray snale i.3 ft. thick-_-_- 0.7

Shale, dark-gray, carbonaceous; includes bony coal stringers

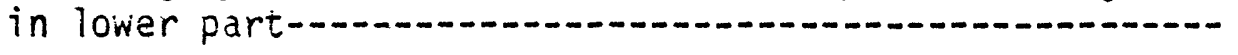

Sandstone, medium-gray, slabby-weathering, massiveappearing, very fine to fine-grained, subangutar, silty, ciayey; includes i-ft. bed of medium-gray silty shale at base; scattered coal stringers and 0.3-ft. coal lense at $1.5 \mathrm{ft}$. below top; locally this unit becomes medium-iight-gray fine- to coarsegrained subanguiar silty sandstone, at least $8 \mathrm{ft}$. thick, and fills a channel cut in the underlying

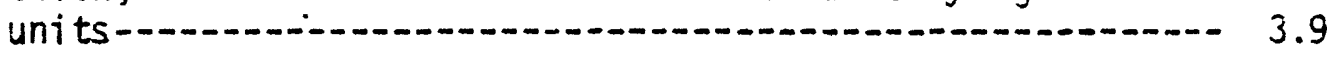

Coal, blocky, bony in basal $0.2 \mathrm{ft}$.; some amber blebs; cut by channeling locally-1.7

Sands tone, medium-gray, slabby-weathering, irregular platy - to thin-bedded, iucaliy cross-bedced, very fine to fine-grained, silty, clayey; grades upward to siltstone in uorer 2 ft.; includes 0.2-0.3-ft. bed of mediuri-derk-gray claystone at too; ?arçe randomly oriented coal fragments; lower contact gradational-1.-1 4.6 
Shale, medium-dark-gray to black, slabby-weathering, very thin bedded; includes carbonaceous fragments and many thin coal stringers at base; becomes black and carbonaceous near middle; loiver contact uneven

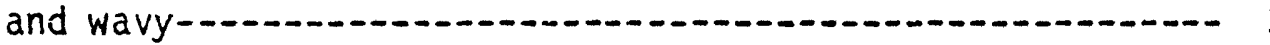

Coal, blocky; inciudes dark-gray carbonaceous shale partings $0.1 \mathrm{ft}$. thick at $0.6 \mathrm{ft}$. above base and 0.4 $\mathrm{ft}$. thick at $1.1 \mathrm{ft}$. above base; 0.25-ft. Ienticular bed of medium-brown pyroclastic silts tone with many

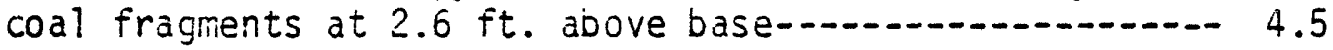

Siltstone and interbedded sandstone; siltstone, medium-

light- to medium-gray (wet), slabby-weathering, laminated to very thin bedded, cross-bedded (very small scale), clayey; sirail caroonacsous plant fragments; sands tone, medium-gray (wer), slabbyweatherirg, lamirated to very tn in bedced, crossbedded, very fine grained, sility; includes interbeds of medium-gray silty shale; numerous coal stringers in lower $i \mathrm{ft}$.; scattered ironstone concretions uo to $0.3 \times 0.5 \mathrm{ft}$. near middle and upper

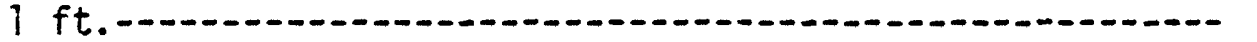

Coal; includes at base $1.25-\mathrm{ft}$. blocky coal bed with common blebs of amber; at least 4 partings of medium-dark-gray inin-bedded shaie uo to $0.6 \mathrm{ft}$. thick (mostly in upper part); lenses and partings of medium-brown ooscurely becded very silty claystone with numerous ranaonily oriented coal fragments at

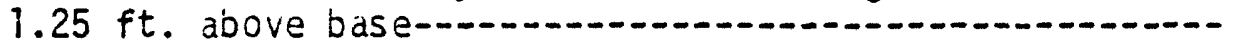

Sancistone, medium-light- to medium-gray (wet), slabbyweathering, massive-appearing, probably very thin bedded, obscurely thin-bedced near top, fine- to very fine grained, subangular, silty, clayey; includes feiv large contorted iense-shaped coaly fragments; shaie stringers up to 0.1 it. thick in lower part; clayey shale bed, $0.2 \mathrm{ft}$. thick, at 1.1

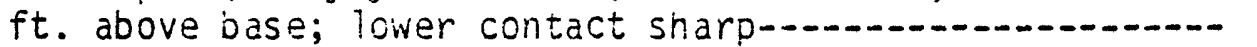

Shale, medium- to medium-dark-gray (wet), massive, silty; includes 0.5 -ft. bed of redium-gray hard noncaicareous siltstone with abuncant small carbonaceous fragments at $0.9 \mathrm{ft}$. below top; coal stringers and dark-gray platy carbonaceous partings in upper $0.9 \mathrm{ft.} . \ldots . . . . . . . .$. 
Coal, blocky; includes pale-brown to medium-dark-gray lenticular snale parting, up to $0 . j \mathrm{ft}$. thick, of pyrociastic origin at $0.9 \mathrm{ft}$. above base; darkgray shale parting $0.2 \mathrm{ft}$. thick at $0.1 \mathrm{ft}$. below top-1.

Shale, medium-gray, slabby-weathering, obscurely thin bedded, uneven fracturing, silty; very silty in upper part; grades at top to 0.7-ft. bed of brownish-gray plastic (when wet) claystone $(1 \mathrm{P}-4 \mathrm{i}) *$ with many

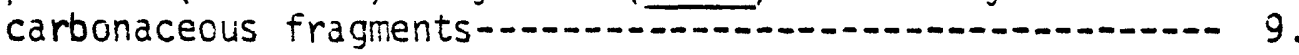

Claystone, medium-gray, hackly-weathering, obscurely

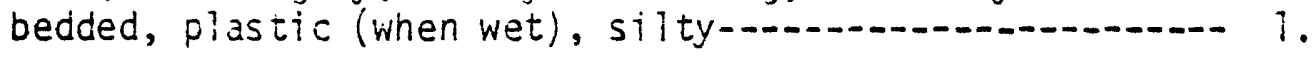

Sands tone, medium-gray, slabby-weathering, massive to thin-bedded, tight, compact, soft, fine-grained, subangular to angular, siity, clayey; grades upward to sandy silts tone (thin sedded in upper part); locally inciudes limy concretionary bodies up to 5 x 15 ft.-.-.-.-. 14.5

Note: Northwest of the sandstone described above, a slide area about 100-150 yards wide shows much distorted and slumpy Beluga rocks. A fault may be concealed in this area, but no definite evidence was found.

Coal, weathered, bony; includes a few thin partings of gray shale; iocally overlain by Pleistocene de-

posits-...-

Siltstone, medium-gray (wet), massive-appearing, clayey; interbedded with shale; few carbonaceous laminations;

few coal beds up to $0.1 \mathrm{ft}$. thick in lower $3 \mathrm{ft} . \ldots . . . . . .11 .5$

Coal, mostly bory; poorly observed-......... 3.

Sandstone, medium-light-gray (wet), massive, soft, friable, fine-grained, subangular, clayey in top $1 \mathrm{ft}$.; no plant fragrents; includes thin interbeds of medium-

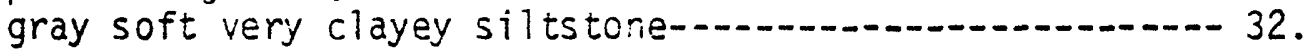

Shale, medium-gray, olocky-weathering, massive, very silty--

Coal, blocky, Dartly bony-1.

Claystone, medium-brown, hackly-weathering, lenticular, plastic; abundant small plant fragments-................ 0.3

*Palynological sample 


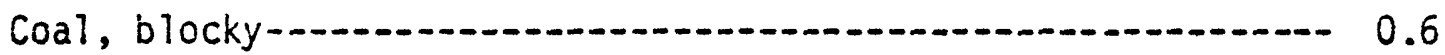

Siltstone, medium-brown, platy-bedded, finely sandy;

may be pyroclastic; abundant carbonaceous material

and plant fragments-... 0.7

Coal, blocky; some impure bony beds in basal part.............. 1.7

Claystone $(1 P-35)^{*}$, medium-gray, hackly- to uneven-weathering, obscurely bedded, silty; smali carbonaceous fragments; includes 0.2-ft. bony coail bed near middle-.......- 1.4

Coal, blocky-_an

Siltstone, medium-gray to light-greenish-gray, hacklyto slabby-weathering, thin-bedied, soft, tight, very clayey; upper $3 \mathrm{ft}$. inciuces large randomiy oriented

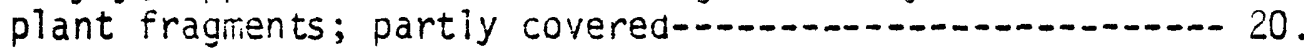

Silts tone and interbedded sandstone; siltstone, mediumgray, hackly - to slabby-weathering, obscureiy thinbedded, tight, compact, clayey; sandstone, mediumgray, hackly- to slabby-weathering, obscureiy thinbedded, tight, compact, fine-grained, si ity; unit contains few carbonaceous fragments; upper $1-2 \mathrm{ft}$. locally concretionary; lower contact sharp and wavy--1.- 20.

Coal, blocky; few amber blebs; includes 0.2-ft. brownishgray shale parting $(I P-32)$ * with many carbonaceous fragments at $0.7 \mathrm{ft}$. above base; $1 \mathrm{ight-brown}$ pyroclastic clayey sandstone with many carbonaceous plant fragments in several thin partings and lenses up to $0.2 \mathrm{ft}$. thick; several thin black carbonaceous shale partings; partings become more comnon in upper $1 \mathrm{ft}$; lower contact sharp-................................ 3.5

Sandstone, medium-gray, locally light-brownish-gray, slabby-weathering, obscurely bedded, tight, fineto very fine grained, subangular, silty, clayey; includes randomly oriented thin coai stringers and

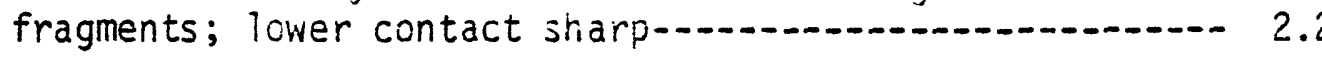

Coal, blocky; blebs of amber; includes few 1ight-brown pyroclastic partings, up to $0.05 \mathrm{ft}$. thick, becoming more numerolis in top $0.5 \mathrm{ft}$.; lower contact sharp--.-.-..-. 
Shale, medium-gray, hackly - to uneven-weathering, massive, silty; some coalified plant fragments; locally becomes brownish-gray claystone wi thi common plant frag-

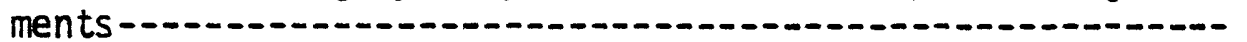

Note: Northwest of the shale described above, a large slide area or channel fill of Pleistocene sediments covers the Beluga formation. A fault probably cuts the Beluga on the southeast side of this area, but the displacement is unknown.

Siltstone, medium-gray, blocky-weathering, massive, not limy, clayey; no plant fragments; top of unit inaccessible and covered by Pleistocene sediments; poorly observed--..-...--

Shale, medium-dark-gray, blocky-weathering, massive, very siity; incluces 2 black carbonaceous shale beds (locally becoming bone coal), up to $0.5 \mathrm{ft}$. thick, at top and base of unit; poorly observed--------estimated 6 .

Sandstone, light-gray, partly iron-stained, blockyweathering, thin- to redium-bedded, soft, friable, partly limy, fine- to medium-grained, subangular, silty,

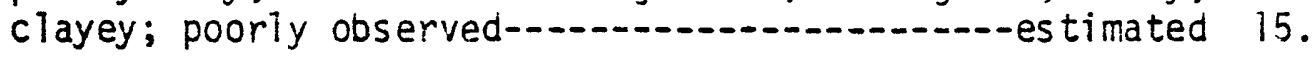

Sandstone, medium-iight-gray, prominately cross-bedded, soft, very friable to weli indurated, locally partly limy, fine- to mediunl-grained (some coarse grains), subangular to subrounded; inciudes scattered pebbleconglomerate ienses, up to $0 . i \mathrm{ft}$. thick, in bottoms of festocn cross-bed sets; i imy concretionary bodies up to $5 \times 20 \mathrm{ft}$.; few lenses and fragments of coal up to $0.1 \mathrm{ft}$. thick; includes at base conglomerate lenses, up to $0.5 \mathrm{ft}$. thick, of pebbles and weil rounded cobbles (up to $0.4 \mathrm{ft}$. in diameter) and lenses, up to $0.3 \mathrm{ft}$. thick, of medium-gray locall! ironstained obscurely bedded shale with carbonaceous stringers and a few pabbles; lower contact discon-

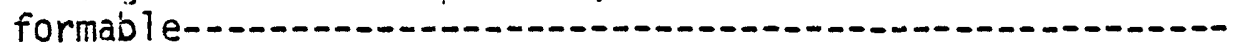

Coai, common bleos of amber; includes $0.25-\mathrm{ft}$. bed of medium-dark-gray caroonaceous sandy siitstone at $1.7 \mathrm{ft}$. above the base; some thin partings of brown pyroclastic material--_.-. 
Sands tone, medium-gray, blocky-weathering, obscurely

thin- to platy-bedded, very fine grained, subanguiar, silty, clayey; incluces $0.5-f t$. beds of shale at oase and top; at $0.8 \mathrm{ft}$. above base a 0.5 -ft. coal lense underlain by a thin bed of claystone (1P-21)

Coal, mostly bony; some bright streaks; includes $0.05-$ $\mathrm{ft}$. parting of brownish-gray silitstone at $0.15 \mathrm{ft}$.

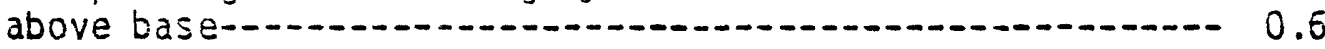

Shale, medilim-dark-gray, hackly-weathering, obscurely bedded, siity; sore plant fragments; iower contact

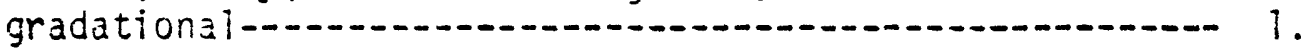

Sands tone, medium-gray, slabby-weathering, obscurely thinbedded, rassive-apoearing, cross-bedded, soft, partiy slightiy limy, fine- to very fine grained, silty, clayey, very "dirty"; includes "wisps" of carbonaceous material; grades uciard to sandy silty shale; lower

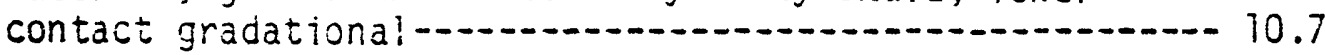

Shale, medium-dark-gray, obscurely bedded, silty; no plant fragments--...-.-.-. 0.4

Siltstone, nedium-gray, obscurely bedded, very limy; abundant carbonaceous plant fragments; forms singie

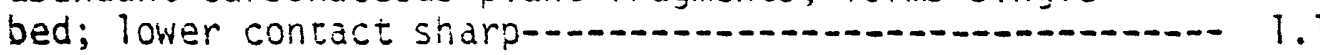

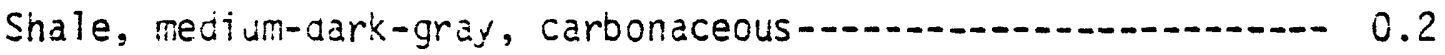

Coal, bony-1 0.6

Shate, medium-dark-gray, obscureiy bedded; some carbo-

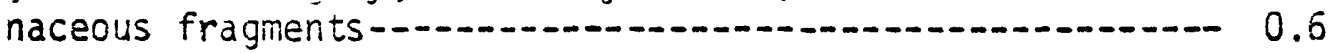

Coal, mostly bony; few amber blebs; inciudes 0.2-ft. parting of fine-grained silty carbonaceous sand-

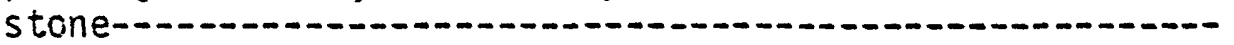

Sandstone, medium-gray, coscurely thin-bedded, soft to well indurated, localiy partly iimy, very fine to coarsegrained, subanguiar to subrounded; locally forms 1 imy concretions up to $5 \times 20 \mathrm{ft}$.; lower $2 \% \mathrm{t}$. grades to very silty shale with plant fragments-_..............-. 9.5

Shale, medilum-dark-gray, caroonaceous, partly very clayey; includes 0.1-rt. imoure coal bed at jise and brown pyrociastic ienses uo to $0.2 \mathrm{ft}$. tinick; unit probady

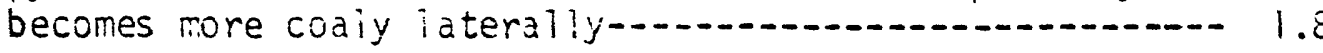


Sandstone, medium-gray, massive, soft, fine- to mediumgrained, subangular, silty, clayey; ieaf impressions in part; includes medium-gray shaie ienses, up to $1 \mathrm{ft}$. thick, with mirior amounts of coai; upper 2.5 ft. fine grained, more silty, clayey, and poorly laminated

Shale, dark-gray, platy- to thin-bedded, slightly silty; abundant carbonaceous plant fragments; includes $0.1-$

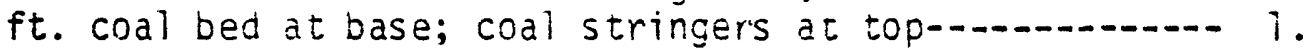

Sands tone, medilum-gray, blocky-weathering, laminated, cross-becied, massive-appearing, soft, tight, very fine to fine-grained, subangular, silicy, clayey-..-.-.-.-- 2.8

Shale, medium-dark-gray, massive, silty; carbonaceous plant fragments and grains of amber........................... 1

Coal; includes claystone parting, $0.05 \mathrm{ft}$. thick at 0.5 ft. above base; very thin brown partings of possible pyroclastic origin in upper $0.5 \mathrm{ft}$.

Clays tone, medium-gray, hackly-weathering, cbscurely bedded, siity; some carbonaceous plant fragments-....-.-- 0.9

Sands tone, redium-gray, slabby-weathering, massive-appearing, localiy indistinctly cross-bedded, poorly indurated, fine- to very fine grained, subangular, silty, clayey; becomes more silty and finer grained in upper half; includes carbonaceous laminations in

lower $1 \mathrm{ft}$.

Shale, medium-gray, partly iron-stained, obscurely bedded,

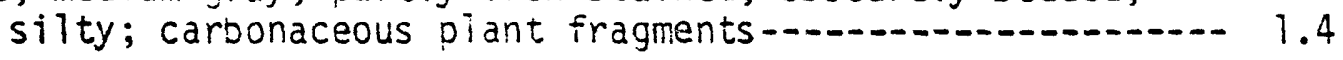

Coal, common amber blebs; medium-brown lenses of pyroclastic origin, up to $0.05 \mathrm{ft}$. thick, in upper $0.5 \mathrm{ft.}-\mathrm{C}_{-}$

Shaie, madium-dark-gray, locally iron-stained, loose shard-like weathering, ienticular; some carbonaceous plant fragments; includes discontinuous coal bed, $0.05 \mathrm{ft}$. thick, at base-1... 0.2-0.5

Shale (1P-6)*, redium- to dark-gray, blocky-weathering, obscureiy bedded, silcy; many randomly oriented very thin carbonaceous stringers, coai stringers, arc coal

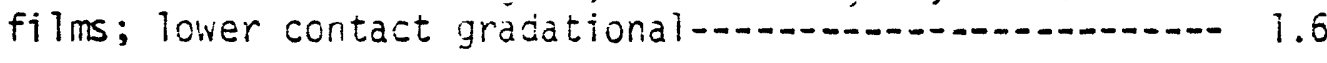


Sandstone, medium-light-gray, obscurely cross-bedded, coarse- to fine-grained, subangular to subrounded, silty, clayey; becomes finer grained toward top-...-.-.-.- 1.5

Note: The rocks described above probably are separated from those described belo'w by a fault of unknown displacement.

Sandstone, medium-light-gray, slightly iron-stained, slabby-weathering, massive to locally very thinly cross-bedded, fine- to medium-grained, subangular to subrounded, 51 ty; becomes very fine grained and sily at top; ircludes scattered coai lenses; overlain by inaccessable coal bed-...-...................- 13.

Shale, brownish-gray, blocky-weathering, obscurely bedded,

sil ty; some carbonaceous piant fragments-.....-..-.-.-.- 0.4

Shale, medium- to dark-gray, fissile to platy-bedded;

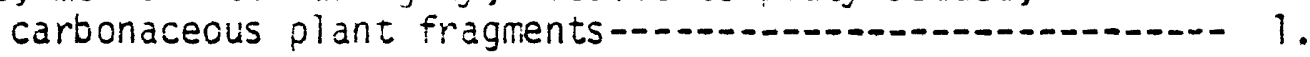

Coal, platy, bony-1. 0.3

Clay, light-brownish-gray to olive-gray (wet), soft, plastic (wet), silty; some small plant fragments-.-.-.--- 0.4

Sands tone, redium-lignt-gray, siabby-weathering, massive to localiy faintly cross-bedded, soft, fine- to medium-grairied (Fen small lenses of coarse grains), silty; includes coal lenses, up to $0.1 \mathrm{ft}$. thick, in shaly zone 2-3 ft. above base; lower contact

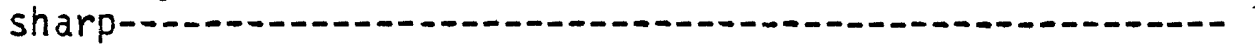

Shale (1P-2)*, medium-1ight-gray to slightiy brownish-gray, obscurely bedded, soft, slightly silty; includes $0.1-f t$. bed of biack carbonaceous shaie $(1 P-2)$ * with very thin stringers and films of coal at base; locally forms iimy concretions that contain plant remains; unit inc?lides carbonaceous plant fragments--.--- 0.5-0.9

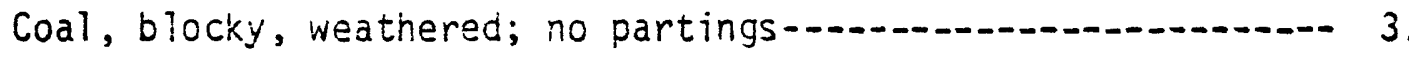

Siltstone $(\underline{P}-I)^{*}$, medium-gray to brownish-gray, massive, soft, very finely sandy, clayey; few smail plant.

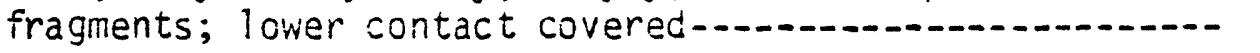

Bottom of measured section at base of sea cliff on soutneast side of fault zone (about 200-300 yards wiae). 


\section{Measured section 16}

Location: Hillside and sea-cilff exposures below Bluff Point 2, near center iV 1/4 sec. 16. T. E S., R. 14 í., Generai1y rortinestward to mouth of Diariond Creek, S'w corner iE $1 / 4$ ith $1 / 4 \mathrm{sec} .8, T .6 \mathrm{~S}$., R. 14 W., Seldovia $C-5$ uliagrargle. This measured section includes localities 83-90, and lies near locality 107, of Barnes and Cobb (1959, pl. 18).

Feet

\section{Pleistocene gravel}

Unconformity

Tertiary rocks -- Kenai Group, Beluga Formation (upper part)

Sandstone, redium-gray, iron-stained in part, obscurely bedded, friable, fine-grained, sibarguiar, silty;

includes 3 interbeds, 0.1 it. thick, of medium-gray

sandy siltstone in iower 2 ft.

Siltstone, medium-gray, ooscureiy bedded, sandy, clayey; some carbonaceous plant fragments; includes irregular dikes and masses of interconnected sardstone similar to overlying uni

Sandstone, medium-gray, iron-stained, slabby-weathering, obscurely bedded, friadie, fine-grained, subanguiar; poor cliff former-...

Siltstone, medium-gray, deeply iron-stained, weathered, obscurely bedded, ciayey; many plant fragments; includes limy siltstone concretions up to $0.4 \mathrm{ft}$.

thick-1 0.5

Coal, blocky, weathered-1.4

Siltstone, medium-gray, brownish-gray (upper $0.3 \mathrm{ft}$. ), iron-stairied, nack?y-uathering, coscurely bedded, clayey; includes $0.05-\mathrm{it}$. Jed ci dark-cray very cartonaceous snaie abo: 0.5 ft. above base; ironstone noduies uo to 0.2 st. thick at ij th above base; interiaminations ot siltstore and very fine grained sancstone at ?.j-?. Ft. above oase and coa?

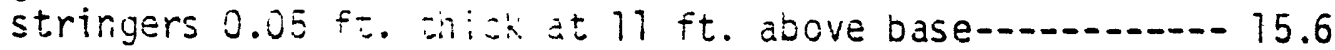


Sandstone, medium-light-gray, iron-stained, obscurely bedded, very fine grained, subangular to subrounded, clayey; contaci fairly snarp-.....

Siltstone, medium-gray, partly iron-stained, nackly-weathering, very clayey; carbonaceous plant fragments; includes thin interbeds of medium-gray silty snale; ironstone nodules up to $0.2 \mathrm{ft}$. thick at 2 and $9 \mathrm{ft}$. above

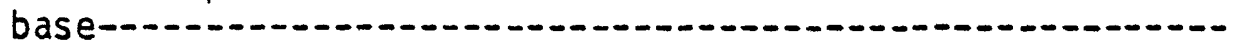

Sandstone, medium-gray (wet), slabby-weathering, obscurely bedded, very friable, very fine grained, subangular

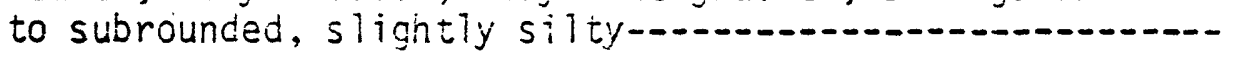

Ironstone, medium-gray, nodular(?); many plant fragments-...-- 0.5

Siltstone, medium-gray, locally very iron-stained, hacklyweathering, ooscurely bedced, cl ayey; carbonaceous

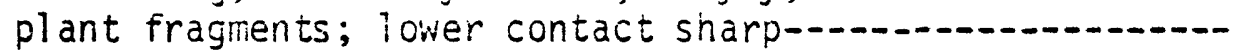

Sandstone, medium-gray, slightly iron-stained, slabby- to massive-weathering, very friable, fine- to mediumgrained, subanguiar to subrounded; lower contact sharp--.-_-

Sandstone, medium-gray to olive-gray, blocky- to platyweathering, hard, very fine grained, subangular to subrounded, very silty, ciayey; asundant piant frag-

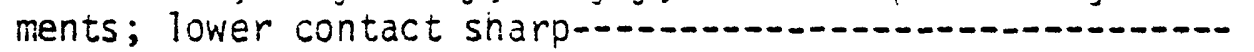

Sandstone, medium-light-gray, partiy very iron-stained, thin-bedded, prominentiy cross-bedded (bedding appears contorted in upeer half), friable, medium-grained (basal part) becoming finer grained upward, subangular to subrounded; locally inciudes concretionary sandstone bodies

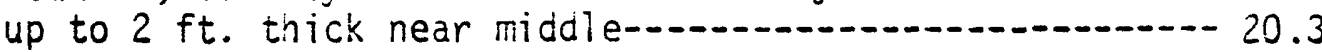

Coal, blocky; bony at base and top-a.-. 0.5

Sandstone, medium-gray, bluish-gray siabby-weathering, probably very thin bedided, even-textured, very fine to fine-grained, suoangular to subrounced, very clavey;

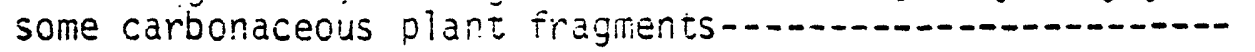

Shale, dark-gray; abundant olant fragments; includes large

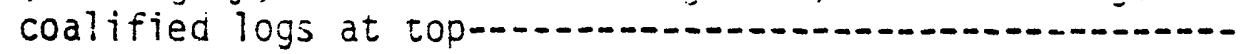

0.4 
Coal, weathered; includes some bony coal partings; locally appears to have one lenticular parting above middle (not accessable)

Siltstone, medium-gray, partly iron-stained, platy- to hackly-weathering, obscurely bedded, nard, clayey; carbonaceous $\mathrm{plant}$ fragnents; includes ironstone nodu? es up to $1 \mathrm{ft}$. thick abcut $3 \mathrm{ft}$. below top;

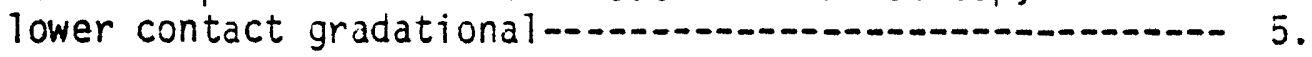

Sands tone, medium-gray, slabby- to hackly-weathering, laminated to very thin becided, partly friable, very fine to coarse-grained, subanguiar to subrounded, slayey; very fine grained and very ciayey in upper half; includes coal stringers and carbonaceous laminations in lower $0.2 \mathrm{ft} . ;$ lower contact sharp-...................... 3.

Siltstone, medium-gray, platy- to hackly-weathering, poor platy - to very thin bedded, clayey; many carbonaceous plant fragments; lower contact fairly sharp-..............

Sandstone, medium-gray, slabby-weathering, mostiy thïnbedded, very fine to fine-grained, subangular to subrounded, clayey; includes near middle few thin beds of medium-gray siltstone with carbonaceous plant frag-

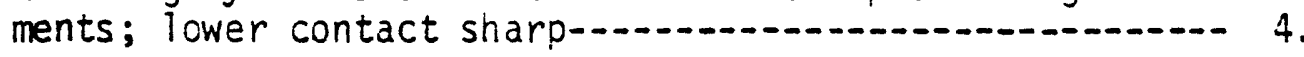

Siltstone, medium-gray, partly iron-stained, platy- to hackiyweathering, poor piaty-bedded, clayey; carbonaceous

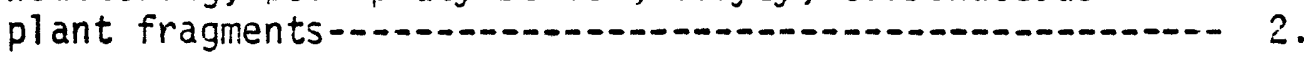

Shale, black, fissile to platy-bedded, carbonaceous; abundant plant fragments and bony coal stringers; medium-gray ironstone iense up to $0.4 \mathrm{ft}$. thick; lower contact gradational-

Coal, mostly blocky, weathered; probably bony at top and base; no partings

Shaie (IP-205)*, medium-gray, obscurely bedded, silty; many randomly oriented carbonaceous plant fragments; few thin coal stringers near middle and top; includes lenticular bed $(0.05 \mathrm{ft}$. thick) of medium-gray very fine grained sandstone and $0.1-\mathrm{ft}$. bed of dark-gray carbonaceous shale at top 
Sandstone, medium-gray, very iron-stained (lower $1 \mathrm{ft}$. ), slabby-, piacy-, and nackly-weathering, iocaily cliffforming, obscurely very thin to tnin-bedied, crossbedded, friabie, redium- to coarse-grained (iower 1 ft.) grading uwward to very ine to fine-grained (upper $6.7 \mathrm{ft.}$ ), slbanguiar to subrounced, si ity, clayey; becones more siity and clayey upward; includes $0.05-\mathrm{ft}$. bed of saridy siltstone $2.5 \mathrm{ft}$. adove base; interbeds of medium-gray siltstone in upcer 5.7 ft.; fel ironstone noduies $(0.3 \mathrm{tt}$. thick) at $0.3 \mathrm{ft}$.

below top; lower contact sharp and uneven-...............- 14.7

Siltstone, medium-gray, platy- to blocky-weathering, poor platy-bedided, very firely sandy, clayey; rany randomly oriented plant fragments; provably cut out by overlyirg sands tone localiy; iower contact sharp-..... 0.0

Sandstone, medium-gray, hackly- to blocky-weathering, obscureiy very thin to thin-bedded, very fine grained, subangular to subrounded, mostiy micaceous and very clayey; mostly abundant ranaomiy oriented plant frag-

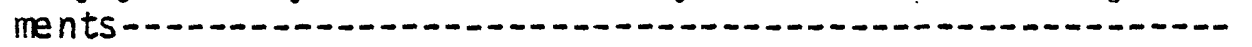

Shale, medium-gray, siightly iron-stained, nackly- to platy-weathering, silty; few carbonaceous plant fragments; inciudes ironstone concretions at about 5 ft. above base; icwer contact gradational-................- 11.3

Sandstone, redium-gray, laminated, friable, very fine grained, Sudangular to subrounded; carbonaceous plant fragments; lower contact gradational-.................-. 3.

Sil ts tone, medium-gray, platy-bedded, clayey; few carbonaceous plant fragments; iower contact gradationai-.....-- $i$.

Siltstone, medium-gray, platy-weathering, thin-bedded, clayey, sandy; interlaminated with medium-light-gray very fine grained clayey sanastone; carboriaceous plant fragments;

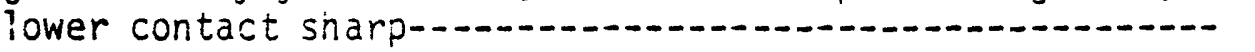


Sands tone, medium-gray, nedium-light-gray-weathering, cliff-forming, slabby-weatnering (usper part), very thin to thin-bedced, prominently cross-bedaed (sets 1-3 ft. thick), friable, firie- to coarse-grained (lower part) grading ueward to very fine grained (upper $4.6 \mathrm{ft}$. ), subangular to subrounded; few large coalified wood iragments; includes thin (up to 0.1 ft.) iron-stained clayey siltstone beds or lenses at about $10 \mathrm{ft}$. above base, locally concretionary at 10 ft. above base; iower contact sharo and possibiy disconformable-

Shale, medium-gray to medium-brown, hackly-weathering, very silty, very finely sandy; doundant caroonacecus plant fragrents; coal stringers at base and toz; includes in upper part nard iimy siltstone concretions

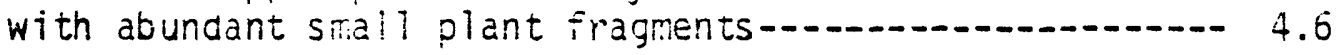

Sandstone, redium-gray, partiy iron-stained, poor olaty-weathering, very thin bedded, partiy laminated, cross-bedded, very fine grained, slayey; lower contact sharp-.......-.- 4.2

Shale, dark-gray, fissile to platy-bedded, very carbonaceous; abundan: plant fragments; lower contact gradaticna $7-\ldots$

Siltstone, medium-gray, nackly-weathering, obscurely bedded, partly laminatea to very thin bedded, clayey; abundant carbonaceous plant frayments except in upper $2 \mathrm{ft}$.; lower contact gradational--...-...- 3.

Siltstone, medium- to light-gray, platy-weathering, laminated, clayey; carbonaceous olant fraginents; lower contact gradational--...-..-

Sandstone, medium-gray, irori-stained, probably thin-bedcied and cross-bedced, friable, even-textured, very fine grained, subangular to subrounded; includes laminations of carbonaceous very fine grained sarids tone in upper $1 \mathrm{ft.}$; lower contact snarp and uneven (possioly a disconformi íy) -

Shale, browrish-gray, olacy - to urieven-weathering; aburdant plant iragments; localiy contains ironstone nodules--.--- 0.5

Coal, bony -

Shale, black, platy-becided, cartonaceous; many coal

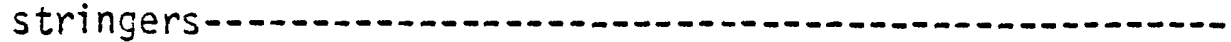


Siltstone, medium-gray, hackly-weathering, obscureiy

laminated, clayey; carbonaceous plant fragments; upper

part appears concretionary; lower contact gradational---- 2.2

Shale, dark-brownish-gray, fissile to piaty-bedded, carbonaceous; abundant plant fragments-..................... 0.4

Coal, olocky - to platy-weathering; abundant soft plarit

fragments-..-..... 0.3

Shale, dark-gray, fissile, carbonaceous; abundant plant fragments-_....... 0.5

Sandstone, redium-gray, very fine grained, subangular to subrounded; abundant carbonaceous fragments; thinly interbedded and laminated with medium-gray silts tone-..--- 1.2

Shale, medium-gray, slightiv iron-stained, hackly-weathering; carbonacecus piant fragments; lower contact gradational--.-.-.-.- 2.

Siltstone, redium-gray, iron-stained, hackly-weathering, obscurely bedded, clayey, fineiy sandy; carbonaceous plant fragments and leaf impressions-_.................... 3.8

Sandstone, medium-gray, slabby- to platy-weathering, thinbedded, friabie, very fine grained, subanguiar to subrounded, clayey; many coalified logs-_................. 3.5

Sandstone, medium-gray, iron-stained, uneven-weathering, tough, very fine grained, subangular to suorounded, clayey; abundant carbonaceous plant fragments; many coalified logs

Coal; good wood texture-1 
Sandstore, Tedium-gray, iron-stained (especially in lower part), cilff-forming, very thin to thin-bedded, prominently cross-bedded (sets about 1 ft. thick), mediumgrained (basal fart) grading upward to dominantiy finegrained (upper $35 \mathrm{ft}$.), Subangular to subrounded; basal part may incluce coarse grains and pebbies iccally; includes thin beds $(0.1 \mathrm{Ft}$.) of clayey iron-rich carbonaceous sandstone; scattered woody coal fragments; at about $13 \mathrm{it}$. above base iense $(0.2 \times 2 \mathrm{ft}$.) of iron-replaced wood(?) material; at 26 ft. above base one small subrounded cobole of hard metamoronic(?) rock; gray shale pebbles about $36 \mathrm{ft}$. above base; at $42.5-43.5 \mathrm{ft}$. above base 2 bets $(0.2 \mathrm{ft}$. thick) of medium-gray very silty shale with aoundant large coaly plant fragments; upper $1 \mathrm{ft}$. includes large fiattened coalified logs; lower contact sharp and disconform$a b l e-$

Shale, medilin-gray, iron-stained; may include ironstone concretions; locally cut out by overlying sandstone;

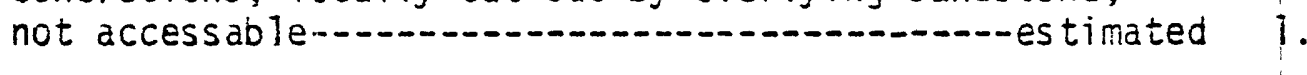

Coal, blocky; no partings-_.-.

Sandstone and interbedded siltstone; sandstone, mediumgray, fine-grained, subangular to subrounded, clayey; limy (lower $0.5 \mathrm{ft}$.); many caroonaceous iaminations; forms beds up to $0 . \bar{j} \mathrm{ft}$. thick; siitsione, mediumgray, hackly- to biaty-weathering, thin-bedded; some plant fragments; includes few interbeds of medium-

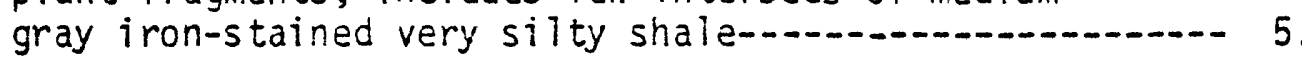

Coal; intarbedded with dark-brownish-gray carbonaceous shale--

Siltstone, medium-gray, partly iron-stained, slabby- to hackiy-weathering, coscurely bedded, clayey; some plant fragments; iower contaci gradational-.............. 1.1

Sandstone, redium-gray, slabby-weathering, obscurely dedded, friable, fine- to medium-grained, clayey, sliahtiy silty; becories yery fine graired at top; includes few sardy siltstone beds and coal fragients in upper half; lower contact sharp-...-...-

Shale, medium-gray, osscureily bedded; includes thin coal

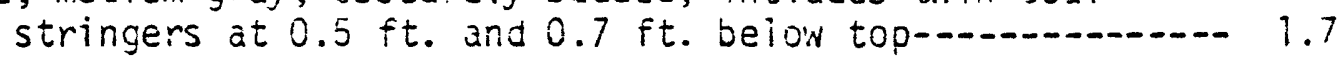


Shale, dark-brownish-gray to biack, very carbonaceous, hard-....

Sandstone, dark-brownish-gray, very fine to fine-grained,

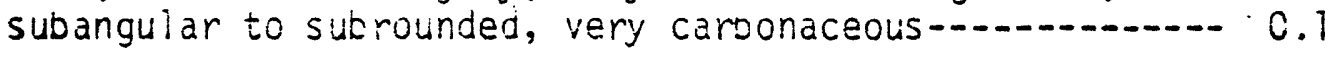

Siltstone, dark-brownish-gray, obscurely platy-bedded, hard, sandy, claysy, very caroonaceous-a. 0.3

Sandstone, medium-gray, partiy iron-stained, thin-slabbyweathering, opscureiy bedded, very friable, finegrained, subanguiar to subrounced; many carbonaceous laminations and trin coal strinjers in ueper 0.1-0.2 ft.; lower contact snarp-a

Siltstone, medium-gray, light-gray-hackly-weathering, obscurely bedded, very finely sandy (iower part), clajey; some carbonacecus piant fragments; inciudes in upper $0.6 \mathrm{ft}$. irregular stringers and thin lenses of very fine grained sandscone and many rancomily oriented

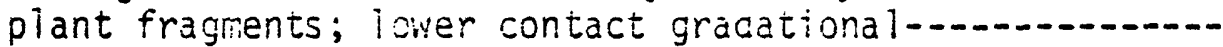

Sandstone, medium-gray, slabby-weathering, obscurely bedded, soft, friable, fine-grained, subanguiar to subrounded, slightly siity; becomes very fine grained at top;

lower contact sharp-a

Shale, medium-gray, hackly-weathering, osscurely bedded; some caroonaceous piant iragments

Coal, bony; interbedded dark-gray carbonaceous shale-...-.-.-

Siltstone, medium-gray, hackly- to siabby-weathering, obscurely bedded, clayey; carbonaceous dlant fragments in upper hali; iover haif includes approximateiy 1 ft. of medium-gray very fire grained clayey sanastone; 0.2-ft. bed of daik-brownish-gray fissile to platybedded carbonaceous shale with abundant plant fragments about 1.4 it. Delow top-

Shale, medium-dark-gray, platy-weathering, poorly fissile,

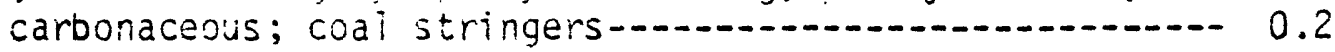

Coal, blocky, weathered-1. 0.3

Siltstone, medium-licht-gray, hackiy-to slabby-waathering, obscureiy beceed, rard, very finely saridy, clayey; small carbonaceous oiant frautents in upper $0.2 \mathrm{ft}$. ; lower contact gradational 
Shale, medium-gray, hackly-weathering, obscurely bedded;

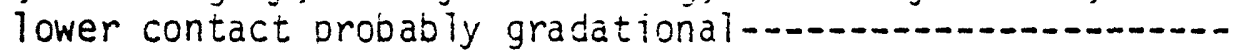

Sandstone, redium-gray, slabby-weathering, obscureiy bedded, very fine grained, subangular to subrounced, siity, mostfy very clayey; lower contact sharp-................- 2.

Siltstone, redium-gray, hackly-weathering, mostly obscurely bedded, partiy laminated to very thin bedded, ciayey; some smali-scale cross bedding: includes few beds of medium-gray very fine grained sands tone $1-2$ ft. thick near middle-...-..-... 10.

Coal and interbedded dark-gray carbonaceous shale; carbonaceolis plant fragments on bedding planes; lower

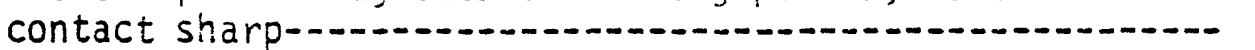

Sandstone, redium-gray, obscure?y bedded, friable, finegrained, subangular to subrounded, silty, clayey; lower contact snarp-............... 1.1

Silts tone, medium-gray, hackly - to slabby-weathering, obscurely very thin to thick-bedded, clayey; interbedded witn very fine grained clayey sanos tone; unit about three-fourtins siltstone-.............................

Shale, medium-gray, obscurely bedded; includes at top

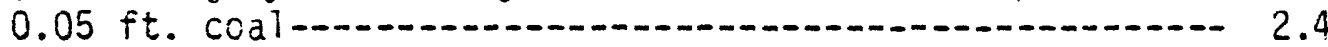

Coal, blocky, partly bony-_... 0.5

Shale, medium-gray; abundant carbonacecus olant fragments and coaly stringers at base; iower contact

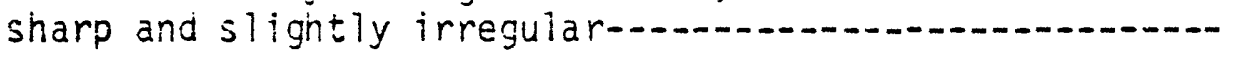

Sandstone, redium-gray, poorly very thin bedded, locally limy and hard, very fine to fine-grained, subanguiar to subrounded; abundant cartcnaceous plant fragments in top 0.1 it.; locally forms resistant ledge; lower

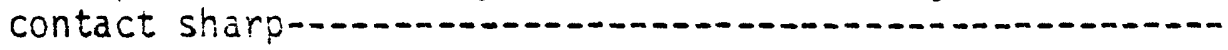

Shale, medium-gray, obscurely bedded, very silty (basal pärt); some carbonaceous piant fragments; includes $0.1-\mathrm{ft}$. bed of coal and dark-gray caroonaceous shale at $1.6 \mathrm{ft}$. above base; 0.2-ft. bed of dark-gray carbonaceous shaie and coal stringers $2.2 \mathrm{ft}$. bel civ tov; 0.5-ft. bed of medium-gray partly iron-stained very fine to fine-grained sandstone $0.3 \mathrm{ft}$. below top; lower contact gradationai-..- 
Sandstone, medium-gray, slabby-weathering, partiy laminated to thin-dedced, iire-gramred, subangular to subrounded; becomes very fine grained and clayey in upper 1 ft.; few carbonaceous 0 lart fragments in upper part; iower contact sharp- 3.5

Siltstone, medium-gray, partly iron-stained, platy-weathering, very in in to tnin-bedced; sandy in lower part, clayey; carbonaceous piant fragments on becding pianes in lower part; includes $0.0 \equiv-F t$. bed of daris-gray very carbonaceous silizstone at $0.0 \mathrm{ft}$. above base; poorly exposed-...-

Coal, blocky-

Siltstone, dark-orownish-gray, very thin bedded, laminated, clayey; abundant small zaroonaceous piant fragments;

lower contact grauationa $1-\ldots .5$

Sandstone, medium-gray, thin-slabby-weathering, very fine grained, sibangular to subrounded, sility, clayey-...... 1.5

Shale, dark-gray, fissile, carbonaceous; abundant smail plant fragments- 0.2

Shaie, medium-gray, slabby- to hackly-weathering, probably very thin bedded, very siity; includes 1 pebble near middle-.. 4

Shale, carbonaceous; includes some bony coal-................- 0.4

Siltstone, redium-gray, slabby-weathering, obscurely bedded, sancy, alayey; no caroonaceous plant fragments seen; lower contact gradational- 1.3

Sandstone, medium-gray, mostly thin-slabby-weathering, friable, soit, very fine grained, subangular to subrounded, clayey in lower part; lower consact probably gradational-a

Shale, medium-gray, hackly-weathering; small carbonaceous plant fragments- 1.

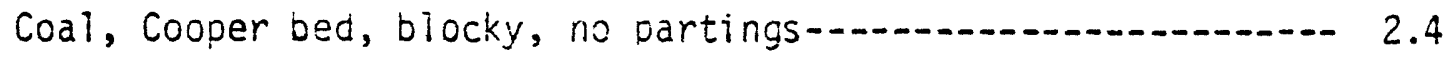

Shale $(10-183) *$, redium-gray, hackly-weathering, platybedded; ironstone nodules about 0.2 ft. thick at 0.2

ft. above base-1.5

*Palynological sample 
Coal, blocky, mostly dul1; much wcody texture on bedding planes

Shale (1P-183)*, medium-gray, hack?\%-weathering, piatybedded; few carbonaceous oliant fracments; includes near micdle 2 beds of dark-gray io black cartonaceous shale $(0.1 \mathrm{ft}$. thick) witn coal stringers in lower bed-1

Coal,

Shaie, medium-gray; poorly observed-1

Covered interval-an- 30

Shale, medium-gray, slighty iron-stained, nackiy-weathering, obscuraly bedced; ro piant fragments seen; includes abundant ironstone nodules about $0.5 \mathrm{ft}$. thick at $1.5 \mathrm{it}$. above base; $1.5-i t$. bed of silts tone 3.5 $\mathrm{ft}$. above base--.-.-.-.

Coal, bony; includes a 0.1-ft. bed of dark-brownish-gray

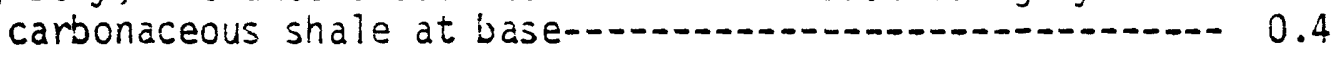

Siltstone, medium-gray, thin-bedded, hard, finely sandy; abundant coalified plant fragments; lower contact sharp--

Sandstone, medium-gray, commoniy iron-stained, thin-bedded, prominentiy cross-becded (sets about $2 \mathrm{ft}$. thick); beding localiy contorted (load structures), friable, mostiy medium-grained, subangular to subrounded, silty; basal 1 it. coarse grained; iocaliy includes peobleconglomerate beds up to $1 \mathrm{ft}$. thick; large coaly wood fragments up to $i$ it. Tong; some claystone ciasts $(0.7 \times 0.2 \mathrm{ft}$.$) ; interlaminations of carbonaceous$ material in beds uo to 0.1 it. thick; becomes less cross-bedded and finer grained $8 \mathrm{ft}$. above base; locally liny and concretionary in a 2- ft. zone $18 \mathrm{ft}$. above base; lower contact snare and wavy...................

Siltstone, medium-gray, iron-stained (on joints), mediumlight-gray-hack!y- to claty-weathering, obscureiy bedded, hard, tough, slightly limi, clayey; abundant Dlant fragrents; includes redium-gray iroristone concretions us to $0.5 \mathrm{ft}$. thick with abundant olant fragments; unit localiy cut cut by overlying sandstorie-...-.- 2.2

Coal, blocky-a.t. 0.3 *Pàlynological sumple 
Shale, medium-gray, mostly hackly-weathering, slabby-weathering (upper i ft.), projably platy-becced (obscure); no plant fragments seen; inclices nurerous ironstore concretions up to $0.5 \mathrm{it}$. thick in a 2-ft. zone 1.5

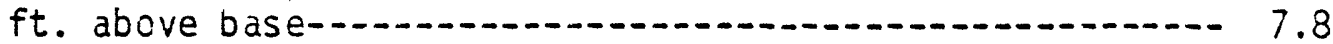

Coal, bony; includes medium-gray' poorly platy-bedded carbonaceous shale with abundart plant fragments-........-.-. 0.8

Claystone (IP-180)*, medium-gray, slight green tint, hacklyto poorly conchoidal-weathering, ooscureiy bedded;

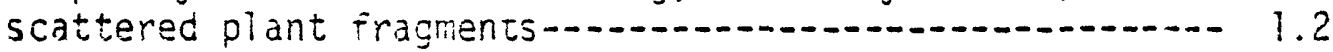

Coal, bony, platy-weathering; lower contact sharp-1.......-.-.- 0.6

Shale (1P-i79)*, medium-gray, nackly-weachering, obscurely piaty-bedded, silty; fein carbonaceous piant fragments; inc?udes a 0.2-ft. Ded of mediumgray fire-grained sandstone with scattered plant fragments at $5.5 \mathrm{ft}$. above base; $2-\mathrm{ft}$. bed of mediumgray very fine grained sandstone at 2 ft. below tos;

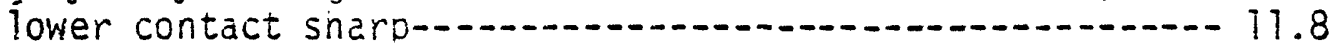

Sandstone, medium-gray, iron-stained, slabby-weathering, friable, fine-grained, subanguiar to subrounded, sligntly silty; mytrmicaliy interbedied with siltstorie beds wo to $0.05 \mathrm{ft}$. thick about $0.4 \mathrm{ft}$. apart-1................... 3.9

Sandstone, medium-gray, locally very iron-stained, slabbyweathering, prominently cross-bedded (sets about 3 ft. thick), medium-grained, subangular to subrounced; clayey ironstone nodules $0.3 \mathrm{ft}$. thick at $3 \mathrm{ft}$. above base; includes at 2 it. below top a $2-\mathrm{ft}$. zone containing angular claystone clasts (up to $0.3 \mathrm{ft}$. long) with leaf impressiors; upper $2 \mathrm{ft}$. includes laminations of iron-rich clay and carbonaceous material; top marked by $0.5-f t$. bed oi Diaty-bedded hard iimy sandstone with abundant laminations of carbonac $=0$ us piant material; lower concact gradationai-.....................-. 12.3

Sandstone, medium-gray, thin-bedded, very fine to finegrained, subangular to suicrunced; intertedded with scre sandstone similar to below; includes at about 1 ft. beijw top a 0.5-ft. bec of sandstore containing small ironstone concretions and overlain by a 0.05-ft. coal stringer; lower contact sharp-1..-...- 8.4 
Sandstone, rediun-gray (wet), poor-slabby-weathering, very thin bedied, very fine grained, subangular to subrounded, very silty; plant fragments on bedding planes and large leaf imoressions near base-...-...-.....- 3.6

Sandstone, medium-gray, locally ledge-forming, hard, limy, very fine grained, subanguilar to subrounced, very silty, concretionary; abundant smali caroonaceous

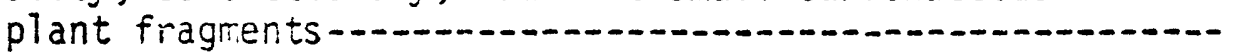

Sandstone, medium-gray, localiy very iron-stained, cliffforming, very thin to thin-bedded, prominent?y crossbedded (sets up to $3 \mathrm{ft}$. thick), very friable, fineto medium-graired, subangular to subrounded; includes at base round pebbles and coboles of cristalline rocks up to $0.2 \mathrm{ft}$. in diameter; ienses of limy sandstone, up to $0.8 \mathrm{ft}$. thick, with abuncant carbonacecus plant fragments, coal stringers, inid scattered ironstone pebbles; icwer contact starp. Sanastone dikes from this unit extend upward into the overlying $0.7-f t$.

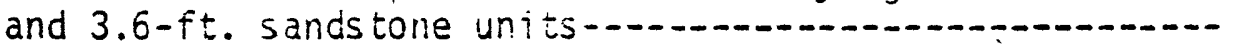

Siltstone, medium-gray, slabby-weathering, laminated to very thin becded, ciayey; abundant carbonaceous plant fragments on bedding surfaces; includes many laminations of very fine grained sands tone; a $0.5-\mathrm{ft}$. bed of medium-gray friable sandstone at $0.8 \mathrm{ft}$. below top;

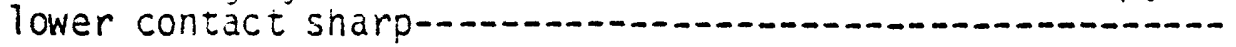

Sandstone, medium-gray (wet), obscurely bedced, very friable, fine grained, subangular to subrounded, silty;

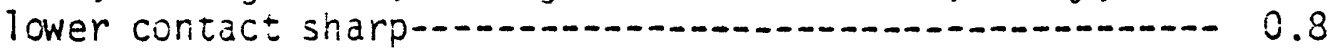

Shale, medium-gray to dark-brownish-gray at base, ironstained, hackly-weathering, ooor platy-bedded; few carbonaceous plant fragments; includes an 0.8-ft. bed of medium-gray very thin beuded sandstone at $3 \mathrm{ft}$. below top; this unit wedged out to the immediate north-

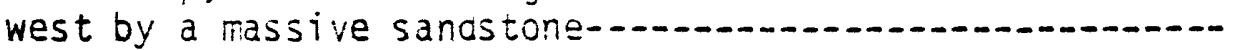

Coal, mostly blocky, poorly odserved; includes near middle at least 2 snaie partings about $0.3 \mathrm{ft}$. inick and 0.5 ft. afart; shale weathers redium light cray and contains abundant carbonaceous piant fragrents and ieat impressions; coal may' include cther partings less than

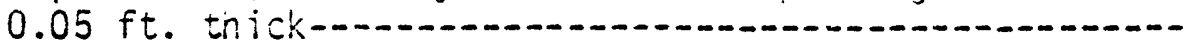


Note: The 0.3-ft. partings increase in thickness southeastward to about $2.5-3 \mathrm{ft}$. in a distance of about $200 \mathrm{yd}$.

Siltstone, medium-gray, partly iron-stained, hackly- to subconchoidal-weathering, obscurely bedded, very clavey; abundant $p$ lant fracments; few tnin coal stringers; unit wedges out in iess than $50 \mathrm{ft}$.; maximum thickness

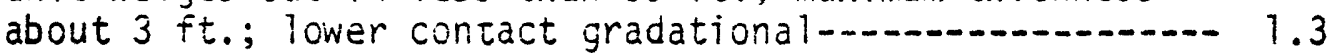

Sandstone, medium-light-gray, cliff-forming, platy - to thiri-bedded, cross-bedded, fine-grained, subangular to subrounded, silty; ircludes many carboriaceous laminations in 1.5-ft. zone $3 \mathrm{ft}$. above base and in usver $6 \mathrm{ft}$; upper $3 \mathrm{ft}$. Secones very fine grained and very silty with many siltstone interbeds; lower contact sharp-n

Shale, mediun-gray, hackly - to shard-like-veathering, probably platy - to very thin bedded, silty; abundart plant fragrents; includes silt-filled worm burrows (?) in lower half; usose nalf locally limy, fairly hard, and concretionary; over contact sharo and slightly undulatory; unit aosent about $400 \mathrm{yd}$. to northwest.......

Sandstone, medium-light-gray, partly iron-stained, massiveweathering, cilif-forming, thin-to platy-bedded, prominertiy cross-bedaed (sets about $1 \mathrm{ft}$. thick), friable, mostly fire-graired (some redium grains), subangular to subrounded; scattered peboles of shale and metamorpicic rocks at base; includes coal stringers up to $0.1 \mathrm{ft}$. thick about $0.5 \mathrm{ft}$. above base; abundant carbonaceous iaminations about $1 \mathrm{ft}$. above base; locaily iron-stained aminated carbonaceous beds, up to $0.2 \mathrm{ft}$. thick, in iower part of unit; several orown-weatinering beds and lenses of laminated siltstone, up to $0.1 \mathrm{ft}$. thick and 0.5-1 ft. asart, in upper $5.3 \mathrm{ft}$. ; lower

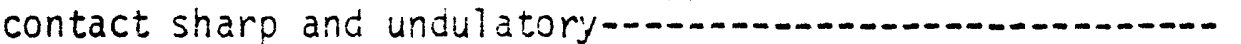

Shale, brownish-cray, partly iron-stained, shard-likeweathering, obscurely jedded, protably thin-bedded; common plant fragments; thirs soutreastward (about $400 \mathrm{yds}$.) to $0.8 \mathrm{ft.}$

Coal, mostiy blocky; thickens scutheastiard (about 400 yd.) to $2.4 \mathrm{ft}$. incluaing 2 partings 
Siltstore, brownish-gray, flaty-bedded, cartly sandy,

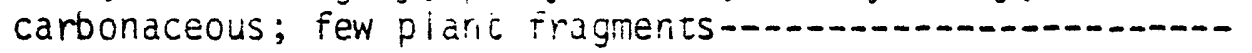

Sandstone, medium-light-cray, trin-bedced, friable, very fine grained, subangular to subrounded; oecomes very silty and clayey toward top; inter? eminated with siltstone similar

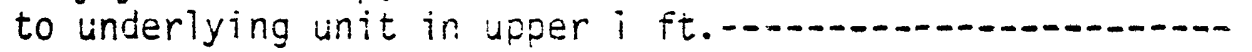

Siltstone and interbedded sandstone; siltstone, medium-gray, platy-bedded to laminatec, clayey, azroly carbonaceous; sandstone, medium-?ignt-gray, friable, very iine grained, subangular to subroundec; forms beds 0.7-0.3 ft. thick; top of unit carbonaceous silts cone inciuding vitreous

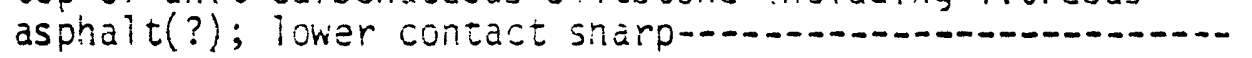

6.

Sandstone, redium-light-gray, cliff-forming, siabby-weathering, massive (basal $3 \mathrm{ft}$.) to tnin-bedded, cross-bedded, friable, fine- to medium-grained (basal bart), finer grained upward, suidangular to suscurced, silty, slightly clayej; inciudes at $2.5 \mathrm{ft}$. above base a $0.2-\mathrm{i}$. bed of ironstained caroonaceous sandstone; uoper $5.5 \mathrm{ft}$. includes laminations of carbonaceous material, siitstone, and ironcemented sandstone; lower contact sharp-...............- 12.

Shale, dark-gray, fissile, carbonaceous; abundant plant

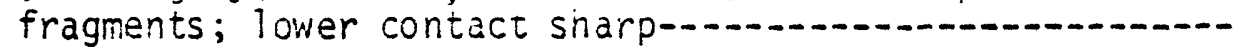

Siltstone, medium-gray, slightly iron-stäined, hackly-weathering, obscureiy bedied. Clayey; some piant fragments; partly interbedded with medium-gray uneven-weatnering very fine grained sancstone; includes in middle 0.5-ft. zone of interbedded siltstone and dark-gray fissile shale witn

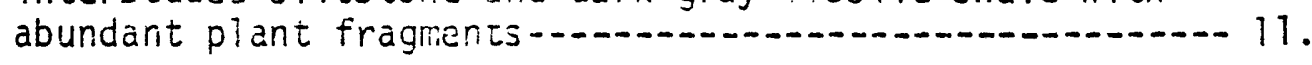

Coal, bony-

Shale, medium-gray, shard-like- to hackly-weathering, obscureiy bedded; fe't carboracsous olant fragments; includes near

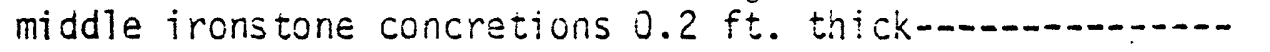

Siltstone, medium-1ight-gray, clavey; some carbonaceous plant fragrents; thin? interbedded witn redium-gray

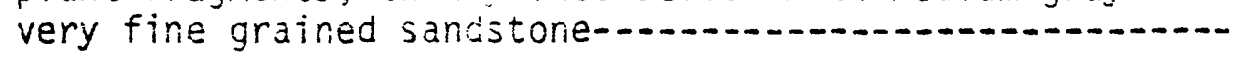

Sandstore, redium-light-gray, siabby- to rounced massiveweathering, thin-bedded, cross-bedded fine grained, subargular to anguiar, silty; concretionary and limy in lower $2 \%$. : interbecded with siltstone in.

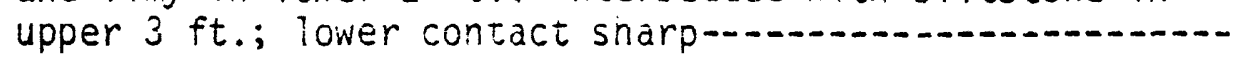


Sandstone, medium-light-gray, thin-bedded, friable, very fine grained, subangular to subrounded; beccmes very silty and ciayey towara top; interiaminated with siitstone similar to underlying unit in upper $1 \mathrm{ft.........-} 3$.

Siltstone and interbedded sandstone; siltstone, mediumgray, platy-bedded to laminated, cl ayey, partiy carbonacesus; sands tone, medium-light-gray, friable, very fine grained, subangliar to subrounded; forms beds 0.1-0.3 ft. thick; top of unit carbonaceous siltstone including vitrecus asphalt(?); lower con-

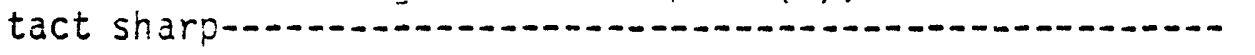

Sandstone, medium-light-gray, cliff-forming, slabbyweathering, massive (basal $3 \mathrm{ft}$.) to thin-bedded, cross-bedded, friable, fine- to medium-grained (basal part), finer grained upward, subangular to subrourded, silty, slightly clayey; inciudes at $2.5 \mathrm{ft}$. above base a $0.2-\mathrm{ft}$. bed of iron-stained caroonaceous sandstone; upper $5.5 \mathrm{ft}$. inciudes laminations of carbonaceous material, siltstore, and iron-cemented sandstone; lower contact sharp--..-..- 12

Shale, dark-gray, fissile, carbonaceous; abundant plant

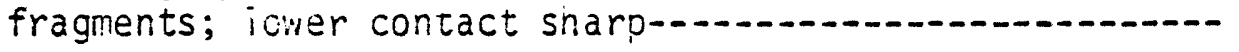

Siltstone, medium-gray, slightly iron-stained, hacklyweathering, coscurely oedded, clayey; some plant fratments; partly interbedded with medium-gray uneven-weathering very fine grained sandstone; includes in middle 0.5-ft. zone ô interbedded siltstone and dark-gray fissile shale with ablindant plant frag-

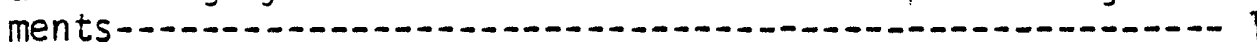

Coal, bony-1.-

Shale, medium-gray, shard-like- to hackly-weathering, obscurely bedded; few carbonaceous plant fragments; near middle ironstone concretions $0.2 \mathrm{ft}$.

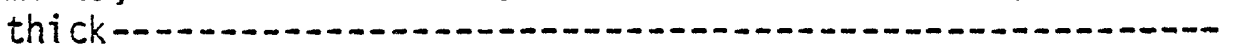

Siltstorie, mediun-light-gray, clayey; some carbonaceous plant fragrents; thinly interoedded with redium-gray

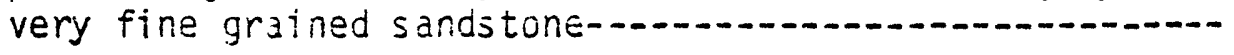

Sandstone, redium-iight-gray, slabby - to rounded massiveweathering, thin-beaded. cross-bedded (smail scale), very fine grained, subangular to angular, silty; concretionary and limy in lower $2 \mathrm{ft}$.; interbedded with with siltstone in upper $3 \mathrm{ft}$.; lower contact

sharp-1.-1-n 
Siltstone, medium-gray, nackly-weathering, probabiy thinbedded (obscure), hard, sandy to very sandy, clayey; no plant fragments seen; inciuces near middle ore prominent concretionary ironstone $D \in C 0.2 \mathrm{ft}$. thick with abuncant plant fragments and leai impressions; lower contact probably gradationai-..............................

Sandstone, redium-gray (wet), riassive-appearing, friable, soft, very fine grained, subangular to subrounded, silty, clayey; lower contact sharp and reguiar-........... 3.3

Silts tone, medium-gray, hackly-weathering, oDscurely thin-bedded, hard, partly sandy, clayey; ironstone nodules $0.05 \mathrm{Ft}$. thick; incluces 2 beds of laminated very fire grained sands tone, 0.7 and 0.3 ft. thick, at 3 and $1.4 \mathrm{ft}$. below top, respectively...... 6.5

Note: The siltstone described above is underlain by a thick coal unit that includes tho partings each about 3 ft. thick. The partings tnin rapidiy norchiwestward. This coal init is readily traceable in the cliffs nor thivestivard, for about $1 / 4-1 / 2$ mile, to near the center of ivin $1 / 4$ iin lis sec. 16, T. 6 S., R. 14 W., where the following description was made.

Coal, blocky; bony in upper $0.2 \mathrm{ft}$; includes 4 lenticular partings (0.2 ft. thick) of dark-gray fissile clayey carbonacsous shale, ith abundant bory coal stringers, at $1.5,2,3$, and 3.5 it. above base; at $0.2 \mathrm{ft}$. below top a 0.3-ft. Ienticuiar parting of brownishgray platy-weathering sandy clayey caroonaceous siltstorie with abundant plant fragments-....................-.

Shale $(1 P-164) *$, medium-gray, poor platy-Dedded (obscure), silty; includes $0.2-\mathrm{ft}$. bed of dark-gray carbonaceous shale about 1.1 ft. above base; lower contact probably

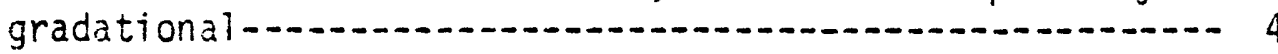

Siltstone, medium-gray, obscurely thin-bedded, clayey;

few carbonacecus olant fragments; inciudes some

fine-grained subangular sandstone near middie-......-.-.-. 3.4

Coal, bony; includes dark-gray carbonaceous shale in

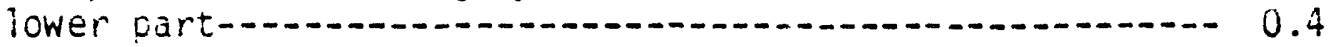

Siltstone, redium-gray, soft, clayey; faw säbonaceous

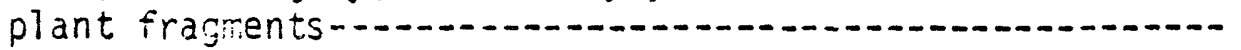


Sandstone, redium-gray, iron-stained, fine-grained, subangular to subrounced; few carbonaceous plant fragments; ironstone noduies up to $0.4 \mathrm{ft}$. tnick-............- 0.6

Shale, medium-gray, hackiy-weathering; iower contact

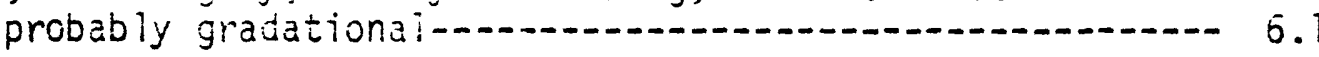

Siltstone, medium-gray, obscurely bedded, hard, clayey; few carbonaceous plant fragments-........................ 3.3

Saridstone, redilum-gray, partly iron-stainod, s?abbyweathering, procaciy cross-bedded, sctt, friable, finegrained, subanguiar to subrounded; usear haif includes several beds of sandy siltstone-.......................... 12.4

Shale, medium-gray, obscurely thin-bedded, siity; scattered carbonaceous plant fragments; includes in middle 3 beas of ironstone noduies uD to $0.3 \mathrm{ft}$. znick; grades to

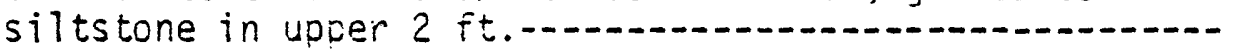

Sandstone, necium-aray, partiy iron-staired, obscurely very thin bedded, friable, fine-grairad, subangular to subrounded, siizy: zome carbonacecus piant fragments; includes ironstone noduies, $0.2 \mathrm{ft}$. thick, about $0.1 \mathrm{ft}$. below top; lower contact sharp-............-

Shale, medium-gray, platy-weathering, platy-oecded, Dartiy silty; soma carbonaceo'ds plant fragnents on bedding surfaces; includes a $0.2-f t$. bed of dark-gray to black carbonaceous shale at $2.5 \mathrm{ft}$. above base; lower contact

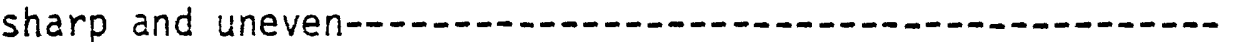

Sandstone, medium-light-gray, partly iron-stained (particulariy in lower 2-4 ft.), rounded-cliff-forming, cross-becded (iarge scaie), partly friable, fineto medium-grained, subangular to suorounded, partiy silty; scattered coal fracrents; scarce cetbles; includes 0.1-ft. lenses of medium-gray shale with abundant plant fragrents; 3 limy concretionary beds (up to $2 \mathrm{ft}$. thick) in lower nalf; lenses and thin beds of brown sardy silitstone, uo to $0.2 \mathrm{ft}$. thick, at about $27 \mathrm{ft}$. above bass; unit beccres progressively finer grained uswara and very fine graned at top; lower contact sharp, lireven, and uricoriformable-........- 4 ]. 
Note: Farther northwest along the sea cliffs, near the northeast correr of sec. i7, T. 5 S., R. 14 W., a 4.5ft. coal bed overi ies a 23-ft. sands tone unit that is correlated with the lower and midale parts of the 41 ft. Sandstone unit described abcve. inis coal includes, at $1 \mathrm{ft}$. above base, a $0.1-\mathrm{ft}$. parting of brownish-gray siltstone containing oyrociastic(?) grains and another parting, $0.3 \mathrm{ft}$. thick and about $2 \mathrm{ft}$. above base, of deeply weathered reddish-brown fissile shale with abundant pilant fragments.

Coal, bony; localiy cut out by channe!ing at base of overlying sandstone--............. 0.2

Silts tone, medium-gray, hackly-weathering, obscurely thinbedded, hard, clayey; some carbonaceous plant fragments; scattered very large coalified tree(?) remains; ironstone nodules in basal part; lpoer $0.5 \mathrm{ft}$. becomes brownish-gray with abundant plant iragments; upper part

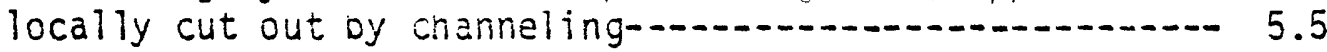

Coal, mostiy blocky; bony in lower and upper $0.2 \mathrm{ft. \cdots ...-.--} 0.9$

Shale, medium-gray, partiy dark-brownish-gray to dark-gray, hackly-weathering, placy - to very in in bedded, hard, partly silty; abuncant carbonaceous plant fragments on some bedding surtaces in lower oart; includes at about 3-4 ft. above base a slumipy 2-ft. bed of ironstained fine-grainea suoangular sands tone overlain $0 \%$ 0.5-ft. bed of brown clayey siltstone containing plant fragments; zones of clayey ironstone nodules, $0.2 \mathrm{ft}$. thick, near middie of unit and $i .2 \mathrm{ft}$. below top; several very thin beds of friable very fine grained subanguiar to subrounded sands tone in uppermidd? e part-- i7.

Coal, biocky; no partings- 0.65

Note: The coal described above is tentatively correlated with a 0.3-ft. bory coal bed, Deneath a cilff-forming sandstone about $10 \mathrm{ft}$. thick, in a large deeply eroded gully rear the norbieast cormer of sec. 17, T. 6 S., R. $14 \mathrm{~W}$. The rocks described beion sre exposed in the lower part of the gully aria northwestwara along the beach to the mouth of Diamond Creek.

Shale, medium-gray, partly iron-stained, hackiy- to sliocorchoidal-weathering, nard; includes concretions and bony coal stringers 
Coal

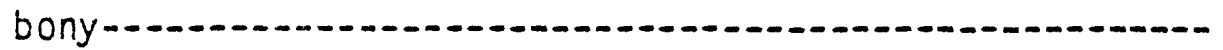

Shale, medium-gray, Dartiy iron-stained, hackly - to subconchoidal-weatlering, hard; includes concreticns and bonecoal stringers up to $0.02 \mathrm{ft}$. thick-........................ 2.3

Coal, bony; includes carbonaceous shaie-...................... 0.4

Shale, redium-gray, hackly- to subconchoidal-weathering; inciudes at base a 0.4-ft. iron-rich bed ; at abcut ft. above base a medium-gray fine-grained sanastone, $0.4 \mathrm{ft}$. thick, overlain by dark-gray caroonaces's shale; at top a 1-ft. bed of sanastone with a sriaro irregular base: iower contact probaoly gradational-....-- 8.5

Sardstone, medium-gray, slabby-weathering, thin-bedded, cross-bedded, fine-grained, subanguiar to angular, slightly clay $y$; includes iaminations of carbonaceous sancstone; a $0.2-\mathrm{ft}$. bed of siltstone at 0.3 ft. below top; lower contact sharp-.......................

Siltstone and interbedied shale and sandstone; siltstone, medium-gray, poor blocky-weathering, laminated to very thin bedded, clavey; some small carbonaceous plant fragments on bedding surfaces; shale, medium-darkgray, lamiriated to very th in bedaed; includes at top a 0.4-ft. bed of medium-dark-gray blocky-weatnering

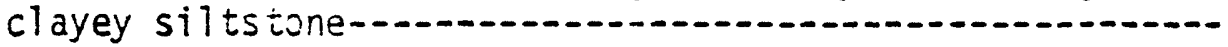

Siltstone, medium-grày, obscurely bedded, clayey; few carbonaceous plant fragments; includes an iron-rich

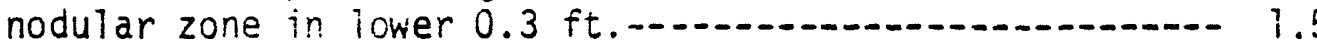

Sandstone, medium-Gray, slabby-weathering, very fine grained, subanguiar, clayey; prodably includes siltstone laminations in thin beds; poorly observed, particularly in lower $8 \mathrm{ft}$.; upper $0.5 \mathrm{ft}$. medium-gray hackijweathering silistone with thin coal stringers at base-1.-_-

Sandstone, mediur-dark-gray, hackly-weathering, irreguiarly bedded to jinated, very fire to fine-grained, subangular, very 0 ? :ey; incluses asundant mediun-darkgray laminations of siltstore; concretionary lim; bodies near middle; lower contact sharp-....................

Sandstone, mediun-cray, thin-s labby-weathering, obscurely thin-bedded, fri able, fine-grained, subangular-..........- 
Siltstone, medium-gray, weakly iron-staired, hard, limy;

ledge former; few smail plant fragrents-_.............- 0.5

Siltstone, medium-dark-gray, firely sandy, clayey; lami-

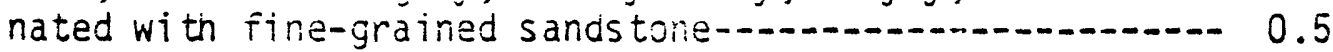

Sandstone, mecium-gray, thin-slabby-iweathering, obscureiy thin-bedded, friable, fine-grained, subangular;

poorly exposed; lower contact sharp-.....................- 2.3

Siltstorie, medium-gray, clayey; worm burrows(?)

Siltstone, medium-gray, laminated to very thin bedded, hard, limy, clayey; ledge former; abundant fine carbonaceous olant material on bedaing suriaces; lower contact fairly sharp-................................. 1.

Sandstone, medium-aray, very fine to fine-grained, sibangular to suorounded, slightly clayey; inciuces a 0.3 -ft. silts tore bed $0.9 \mathrm{ft}$. above base-...............- 2.4

Sandstone and interbedded siltstone; sandstone, mediumgray, very fine to fine-grained, subangular to subrounded, slightly clayey; siltstone becomes dominant

toward top-............... 13.6

Siltstone, medium-gray, iron-stained, laminated, hard, limy, ciayey; ledge former; smail carbonacecus piant, fragnents on dedaing surfaces-........................-. 0.6

Sandstone, medium-gray, slabby-weathering, friable, very fine grained, sudangular, siightiy clayey; incluces a few laminations and thin beds of dark-gray carooraceous siltstone; lower contact sharp-...................

Sil ts tone, mediuri-cray, poor platy- to blocky-weathering, obscurely bedces, not limy, ciayey; ro plant fragments seen; incilides thin interbeds and laminaticns

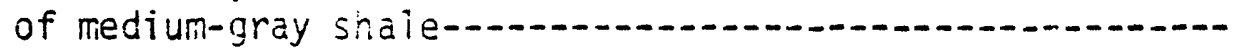

Siltstone, medium-gray, iron-stained, laminated, hard, limy, clayey; ladge former; aburiant small carjonaceous piart fragrents on bedcing surfaces; iower contact sharp-1..-

0.5

Sandstone, medium-gray to light-orour. ?aminated to thinbedded, very fire grained, sutanzular. silty, cisyey, micaceous; upeer !.4 ft. inclug $=5$ many lamirations of

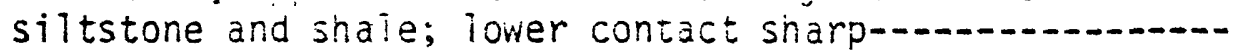


Sandstone, medium-light-griy, platy-oedded, Dartly crossbedded, very fine grained, subangular, silty, ilayey; some carbonaceous siant fragments on jedding surfaces; interbedjed with siltstone and sraie; siltstone comi-

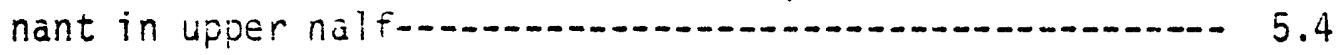

Siltstone, medium-gray, poor platy- to blocky-weathering, obscurely thin bedced, clayey; no olant fragments seen; incluess tnin incerbecs and iaminations of mediumgray shale; basai $0.4 \mathrm{ft}$. limy and foms a slight ledge; small worm burrows(?) in basal part-...................... 18.3

Siltstone, medium-?ight-gray, partly laminated to very thin bedded, cross-becded, nard, sligntiy limy, clayey; includes in uroer 1 t. Taminations and thin beds of medium-gray piaty - to chunky-weathering shale; icwer

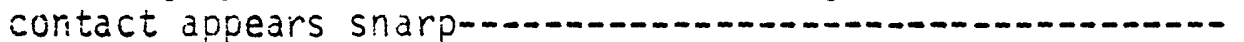

Shale, medium-gray, light-gray-weathering, iron-stained on joint and fractures, hard, silty; includes many siltstone laminations; similar to underlying shale;

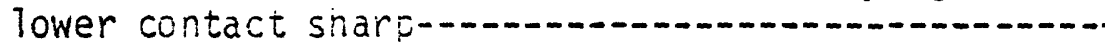

Silts tone, mediun-i ignt-gray, subconchoidal-weathering, clayey; one bed; fractures perpendicular to bedding; no carbonaceous plant fragments; forms lighter color band on hiliside-1...- 0.5

Shale, medium-gray, iron-stained on joints, platy - to chunkyweathering, very thin bedded, hard, very silty; abundant carbonaceous plant fragments; similar to underiying

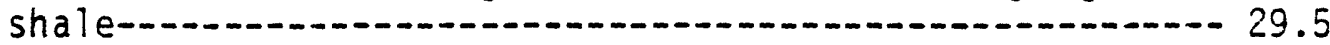

Shale (IP-134 -- basal 1 ft. $)^{*}$, medium-gray, abundant iron-staining on joints and fractures, light-grayplaty - to chunky-weathering, fissile to platy-bedded, conchoidal-frecturing, very silty; inciudes scattered "floating" fine to coarse sand grains and larga granules; carbonaceous plant fragments abundant at base

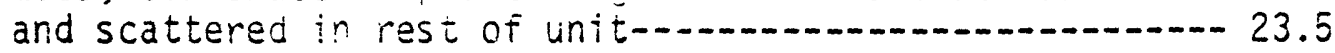

Coal, blocky; inciudes cony coal and black carbonaceous

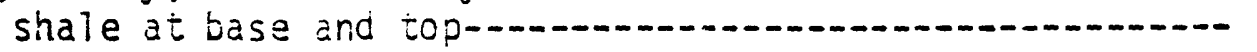


Shale, medium-gray, hackiy - to blocky - and subconchoidalweathering, siightly silty; carbonaceous olant fragments; interbedded near inicdle with subeaual amounts of siltstore and medium-gray tnin-bedded fine-grained partly limy ana concretionary sands tone with carbonaceous Taminations; inciudes a 0.1-ft. bony coal bed about $1 \mathrm{ft}$. above base-1.-.-..- 6

Siltstone, mediur-gray, blocky- to hackly-weathering, obscurely bedued, clayey; few carbonaceous piant fragments; lower contact gradational-......................... 1.

Sandstone, medium-gray, slabby-weathering, obscureiy bedded, fri $\equiv$ le, medium-grained in lower part grading to very fine grained at top, slibanguiar to angular, slightly clayey; lower contact sharp-..................- 5.5

Shale, medium-gray, s? ightly iron-stained, hackly-weathering, obscurely bedded; no plarit iragments seen-..-........-.-- 4.2

Sands tore, redium-gray, thin-slabby-weathering, thin-bedded, probably partiy cross-bedded, friable, ine-grained, subangular to subrounded, si ightly clayey; some carbonaceous plant fragments; interbedded with siltstone in

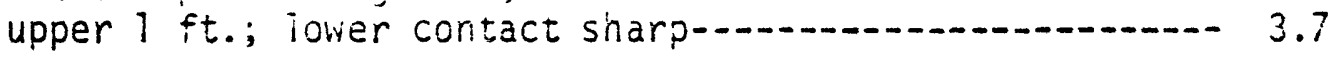

Shaie and interbeuded siltstore; shale, medium-gray, slabby - to uneven-weathering, obscurely bedded; few carbonaceous alant fragments; siltstone, medium-gray, clayey; includes a 0.1-ft. bed of fissile to platybedded carbonazeous shaie about $1.5 \mathrm{ft}$. above base------- 4.5

Coal, blocky; includes a $0.1-\mathrm{ft}$. parting of medium-brown shale at $0.2 \mathrm{ft}$. above base; a 0.3-ft. bed of black carbonaccous sna: a at top; iocaliy upper part of unit includes iimy siitstone(?) concretions (inaccessab $1 \in$ ) -

Siltstone, medium-gray, partiy iron-stained, slabby-weathering, thin-bedjed, hard, si ightiy clayey; includes local lamirations of carbonaceous piant rateriai-........ 4.4 
Coal, mostly blocky; includes at $0.4 \mathrm{ft}$. above base a 1.8ft. parting (Jinches out southeasciard) of mediumbrownish-gray shaie with coal fragments and a 0.?-it. coal stringer near middle; a 0.3-ft. bed of brcwnishgray fissile carbonaceous snaie with abundant plant fragments at top; iateraliy trits unit becomes 1.8 ft. of coal with a 0.1-ft. parting of erown siltstone at $0.5 \mathrm{ft}$. above base-1. 4.

Siltstone, mediun-gray, slabby-weathering, thin-bedded, cross-bedded, nard, clayey, sandy near top; interlaminated wi:n carbonaceous material; includes at 1 ft. abcve base a i.j-ft. bed of medium-gray slaibjweathering fine- to medium-grained sucangular to angular limy sandstone with abundant plant fragments; thin shale beas in upper $i$ ft. of unit; upper 1 it. locally limy and concretionary with abundant plant fragments-..-

Shaie, medium-brown, platy-bedded; few plant fragments-...... 0.6 Coal platy- 0.6

Siltstone, medium-gray, slightiy iron-stained, slabby- to uneven-weatiering, ooscurely bedded, clayey; no plant fragments seen; inciuces an 0.8-ft. sandstone bed about 3 ft. asove sase; lower contact gradational-.....- 7 .

Sandstone, medium-gray, cross-bedded, fine- to mediumgrained, subangular to angular, clayey; locally interlaminated with carbonaceous piant material; lower contact sharp and even-1.2

Shale, medium-gray, subconchoidal-weathering, obscurely bedded, siligntiy siity; no plant fragments-.......... 0.3

Shale, medium-brownish-oray, fissile, carbonaceous; includes coaly stringers-... 0.6

Siltstore, mediun-broinn, hard, sandy, clayey, pyrociastic; carbonaceous piant fragments-... 0.2

Coal, bony

Sandstone, medium-oray, 1 ight-gray-siabby-weathering, trin-bedded, crcss-bedied, fine- to very fine grained, subargui ar to angular. very silty, very clayey; few smai i carbonaceous diant fragments; includes interteas of medium-aray clayey siltstone; fow ironstone nodules at top-... 
Coal, bony; includes bläck carbonaceous shale-...............- 0.1 Bottom of measured section at base of sea cliff at mouth of Diamond Creek. 


\section{Measured section 2}

Location: Creek-bed and hillside exposures on Bidarki Creek from near cen. NE $1 / 4 S E i / 4 \mathrm{sec} .13$ to sea cliff at creek mouth in Sid $1 / 4$ SE $1 / 4$ NW $1 / 4 \mathrm{sec}$. 24, T. 6 S., R. $14 \mathrm{w}$., Seldovia C-5 quadrangie. This location is approximately the same as locality 117 of Barnes and coto $(1959$, pls. 18, 19).

Tertiary rocks -- Kenaj Group, Seluga Formation (upper part)

Feet

Coal, impure, platy-weathering in wpper half to blockyweathering in lower haif; top concealed-..................- 1.8

Covered interval-1.1.

Coal, mostly platy-weathering and bony; poorly exposed;

$1 \mathrm{ft}$. of blocky lecige-forming coal at $0.3 \mathrm{ft}$. above base; includes tro 0.j-ft. veds, at $1.3 \mathrm{ft}$. above base and $2 \mathrm{ft}$. beiow top, of medium-gray fissile shale $(2 p-37)$ * uith abundant carbonaceous piant fragments; Tower contact sharp-.........................-. 6.3

Siltstone, medium-cray, hackly-weathering, obscurely bedded; common carboriaceous plant iragments; inciudes in upper $1 \mathrm{ft}$. some pooriy exposed beds of medium-gray very fine grained very silty sandstone witn abundant fine white plagioclase $(?)$ crystals-....................................... 5.

Covered intervâl-a.

Siltstone, mediur-gray, thin-becided(?), sandy, clayey; abundant plant fragments -.............................- 1.5

Covered interva]

Siltstone, medium-gray, partiy iron-stained, hackiy-weathering, obscurely jedded, clayey; few carbonaceous plant

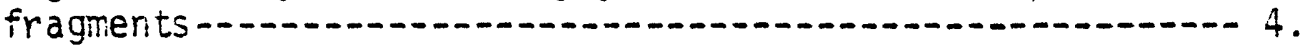

Covered interval-a.

Siltstone, medili-gray, mostiy iron-stained, hackiy-weathering, obscure?y tnin-bedied, partly sandy, clayey; includes $0.3-\mathrm{ft}$. ironstone nodules $2.5 \mathrm{ft}$. above base-.-.-.-- 7 .

Covered intervai-a. 
Coal, weathered, blocky in lower nalf, platy and bony in upper half; icier contact sharp- 2.

Siltstone, redium-gray, hackly-weathering, obscurely thinbedded, clayey, sandy; few caroonaceous plant fragments; includes at base 0.5-ft. bed of medium-gray very fine grained sandstone-1.

Covered interval

Sandstone, medium-gray, very thin bedded, cross-bedded, friable, medium-grained, siity; includes in midide 0.2-ft. bed of redium-gray indurated sandy si?tstone-.-.-- 3.

Covered interval; probably includes $0.5-\mathrm{ft}$. coal bed in lower 2-3 ft.

Shale, mediumi-gray, hackly-weathering, obscurely bedded, partly very siity; some carocnaceous plant fragments; includes at base 0.4-ft. bea of dark-orownish-gray probably piaty-bedded sinale iv th bony coal stringers and abundant caroonaceous material

Coai, bony- 0.6

Covered intervai- 6.5

Coal, mostly blocky; appears bony in top $0.5 \mathrm{ft}$ and basal 0.5 ft.

Shale, deeply weathered; includes 0.5-ft. nodular ironstone bed-1...

Siltstone, medium-gray, much iron-stained, very thin bedded, partly very fineiy sandy-..

Covered intervai 13.

Coal, blocky; includes at base and top 0.2-ft. beds of mediumto medium-dark-gray partly iron-stained fissile to platybedded carbonaceous shale wi in abundant plant fraginents; lower contact sharp....

Sandstone, mediun-gray, nackly-weathering, very fine grained, very silty, ciayey-a. 2.

Covered interval- 15. 
Shale, medium-gray, very thin bedded to fissile; abundant carbonaceous plant fragments; abundant iarge plant fragments in lower 0.3 ft.: includes $0.2-\mathrm{ft}$. Dlocky

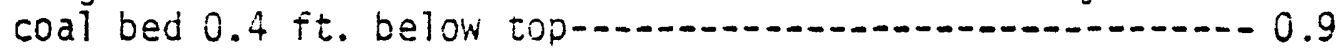

Covered interval-1-2. 2.7

Coal, weathered, bony in lower half, blocky in upper half; abundant woody fragments in lower half-................... 1 .

Shale, medium-gray, hackly-weathering, very silty; common carbonaceous plant fragments; includes ironstone noduies up to $0.5 \mathrm{ft}$. thick with abundant plant fragments---1.

Siltstone and interbedded sandstore; siltstone, mediumgray, partly iron-stained, hackiy-weatnering, obscurely very thin bedded, partly very finely sandy; few carbonaceous piant fragments; sandstone, medium-gray, partly iron-stained, friable, very fine grained-..............-.-.- 2.

Covered interval-1-

Coal, blocky; top very slumpy-_...- 1 .

Shale $\left(\frac{2 P-25}{d y}{ }^{*}\right.$, medium- to medium-dark-gray, partly fissile, clayey, partiy very carbonaceous; abundant carbonaceous

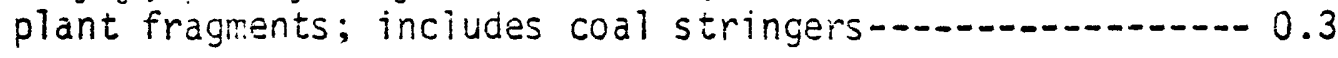

Covered interval-1- 36.

Coal, blocky- 0.5

Shale, medium-gray, very finely sandy, silty; abundant carbonaceous piant fragrents-.-...- 0.8

Covered interval-1

Shale and interbedded coal; shale, medium- to medium-darkgray, fissile; abundant carbonaceous piant fragments; forms beds ip to $0.5 \mathrm{ft}$. thick; coal, blocky - to piatyweathering, bony; forms beds up to $0.5 \mathrm{ft}$. thick-......-- 1.6

Shale (2P-23)*, medilim-gray, blocky-weathering; plastic when wet; abundant carbonaceous plant fragments-..........- 0.7

Covered interval-

Coal, blocky-1. 
Covered interval-an

Coal, blocky-1.-1

Covered interval; includes slumped coal bed, thickness unknown, about $11.5 \mathrm{ft}$. above base-1-..- 81.5

Sandstone, medium-gray, deeply weathered, very fine grained, very silty-1 2.5

Coal, blocky-1. 0.65

Siltstone, medium-gray, iron-stained, deeply weathered, hackly-weathering, friable; inciudes at base ij.3-ft. lense of mediun-gray hard iron-rich(?) siltstone witn abundant plart fragments; carbonaceous in upper $0.2 \mathrm{ft} . \ldots-3.3$

Coal and interbedced dark-gray carbonaceous shale, weathered--- 0.3

Siltstone, medium-gray, iron-stained, hackly-weathering, cbscurely tnir-becded, locally hard and concretionary in upper $1 \div \ldots$; few plant fragments; includes ironstone nodules up to $\mathrm{j} .3 \mathrm{ft}$. thick $1.5 \mathrm{ft}$. below top-..........- 7 .

Covered interval 21.

Sandstone, medium-jray, very thin to thin-bedded, friable, very fine to fine-grained, silty-........................ 2.

Coal, blocky; includes 2 partings of weathered shale, each about $0.05 \mathrm{ft}$. thick, near middie and in lower half; forms small waterfall at top of sea cliff-................- 1.6

Siltstone and interbedded sandstone; siltstone, medium-gray, laminated to very inin bedded, sandy; few sriail carbonaceous plant fragments; forms beds $0.5 \mathrm{ft}-0.8 \mathrm{ft}$. thick; sands tone, redium-gray, iriable, very fine grained, silty; felv carbonaceous plant fragments; iower

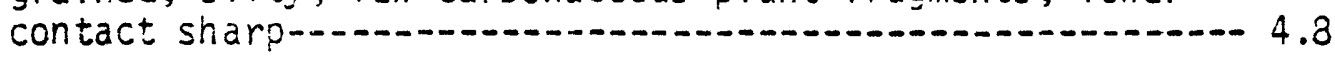

Shale, dark-gray to black, fissile, carbonaceous; comron carbonaceous $2 l$ ant fragments; includes bony coal

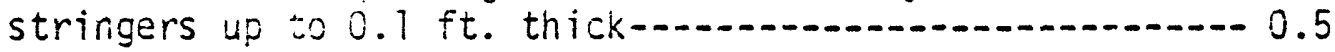

Siltstone, medium-gray, iron-stained, hackly-weathering, obscurely becced, clayey; fen plant fragments-..........- 2.4 
Sandstone, medium-gray, partiy iron-stained, obscureiy thinbedded, friajle, very fine to fine-grained, silty; includes finely interbedded medium-gray siitstone; iower contact sharp-1. 3.6

Siltstone, medium-gray, iron-stained, hackly-weathering, poor very thin to thin-bedded; few smail plant fragnents; large bony coalified tree remains at base-1..............-2 2.2

Shale and interbedded coal; shale, medium-gray, obscureiy bedded, partiy siity, clayey; common carbonaceous plant fragments; coai, very bony; includes black carbonaceous shale laminations in part; unit inciudes at base 0.2-ft. bed of dark-gray carbonaceous shale------- 3.3

Coal, biocky; includes at $1.1 \mathrm{ft}$. above base $0.3-\mathrm{ft}$. bed of deeply weathered medium-gray iron-stained prooably fissile shale vith abundant coai stringers and arbonaceous piant fragrents; few very th in beds or zartings of bony coal in lower block; lower contact sharp--...-.-.- 4.1

Siltstone, medium-gray, hackTy-weathering, obscurely bedded, probably very thin bedded; few carbonaceolis piant fragments; scatrered redium-gray ciayey ironstone nodules up to $0.5 \mathrm{ft}$. tnick in lower $5.5 \mathrm{ft}$.; includes at $1 \mathrm{ft}$. below top $0.5-f t$. bed of medium-gray friable very fine grained sandstone; at top 0.5-ft. Dec of medium-darigray siltstone with abundant plant fragments; lower contact fair?'y sharp--.-10 10.5

Sandstone, medium-rgray, slabby-weathering, obscurely thin bedded, friabie, very fine grained, silty; inciudes medium-gray siltstone beds up to $0.2 \mathrm{ft}$. thick near middle and in upper one-third of unit; lower contact sharp--.- 2.6

Siltstone, mediun-?ight-gray, lenticular, partly platybedded, limy; fen carbonaceous plant fragments; lower contact sharp-a.-.

Silts tone, medium-gray, hackly- to shard-like-weathering in upper part, very th in to thin-bedded, very sandy in upper part, clavey; few carounaceous olant fracments; includes two 0.5-ft. beds of medium-light-gray very fine grained locally limy sands tone about 1.5 and $5 \mathrm{ft}$. above base; $0.05-\mathrm{ft}$. bony coal bed $2.5 \mathrm{ft}$. beion top; upper $3 \mathrm{ft}$. dominantly medium-gray silty shale; lower

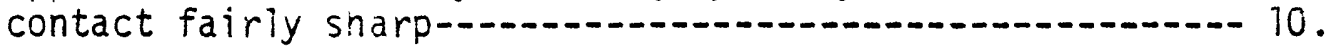


Shale, dark-gray, fissile to platy-bedded, fairly hard, tough, silty, carbonaceous; includes some very thin coal stringers; medium-gray hard limy siltstone concretions with many leat inpressions-_....................... 0.9

Shale, mediur-dark-gray, probably platy-weathering, fissile to platy-bedded; many carbonaceous plant iragments on bedding--1.-1 0.6

Coal, partly bony; includes near middle $0.05-\mathrm{ft}$. parting of dark-gray shale---1-1

Shale, dark-gray, fissile-weathering, carbonaceous-...-.-.-.-- 1.5

Coal, mostly bony-1

Shale $(\underline{2 P-i 1}) *$, medium-gray, obscurely bedded, clayey; many caroonacsous plant fragments; includes $0.05-\mathrm{ft}$.

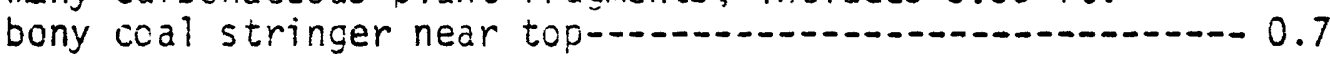

Shale, dark-gray to black, platy-bedded, very carbonaceous; includes thin bony coal siringers; lower contact gradational -...-. 0.5

Siltstone, medium-gray, platy- to hackly-weathering, very thin bedded, clayey, finely sandy'; lower contact probably gradational--.-...-. 1.6

Sandstone, medium-gray, slabby-weathering, obscurely very thin bedded, friable, very fine grained, silty; few thin pieces of coal; lower contact sharp-............- 1.4

Siltstone and interbedded shale; medium- to medium-dark-gray, hackly-weathering in lower half, hackly- to platyweathering in uoper half, laminated to thin-bedded, clayey; some small carbonacecus plant fragments; lower contact sharp-........ 4.5

Sandstore, medium-gray, thin-bedded to laminated, crossbedded, friable, very fine grained, silty; large ironreplaced coalified wood fragments; lairinations of carboriaceous material; lower contact sharp-.........-...-- 2.

Siltstone, redium-dark-gray, platy-bedded, very clayey; abundant carsonaceous olant fragments; inciudes coai stringers -....... 0.5

Coal, platy-weatnering-a. 0.3 
Sandstone, medi um-gray, thin-bedded, indurated, very fine grained, clavey, very silty; abundant piant fragments; includes beds, up to $0.2 \mathrm{ft}$. thick, of medium-gray siltstone with abundant leaf impressions in part; unit becomes principally sanay siltstone in upper

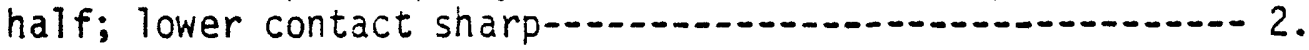

Sandstone, medium-gray, iron-staired, slabby-weathering, cliff-forming, thin-bedded and cross-bedded in upper part, mostly very friable, fine-grained to very fine grained in upper part, locally limy arid concretionary, silty; scattered carbonaceous wood fragments; lower two-thirds includes limy concretions up to $2 \mathrm{ft}$. thick-_- 18.

Coal, blocky; includes at base 0.2-ft. bed of dark-gray to dark-brownish-grav carbonaceous shale with very thin

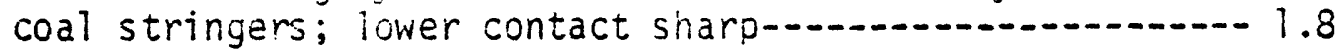

Siltstone, medium-gray, obscurely bedded, clayey; includes at $3.3 \mathrm{ft}$. below top $0.8-\mathrm{ft}$. bed of medium-gray slabbyweathering laminated very fine grained silty sands tone; at $1.5 \mathrm{ft}$. belcw top $0.5-\mathrm{ft}$. bed of medium-gray sility shale with plant fragments; lower contact gradational----- 6 .

Sands tone, medium-gray, slabby-weathering, friable, very fine grained, very silty; iower contact gradational-.....- 0.5

Silts tone, medium- to medium-dark-gray, hackiy-weathering, laminater, very finely sandy, clayey; lower contact gradational-_.-. 0.5

Shale, medium-gray, hackly-weathering, obscurely bedded, probably thin-bedded, clayey, very siity; few carbonaceous plant frägrants; includes at base $0.2-\mathrm{ft}$. bed

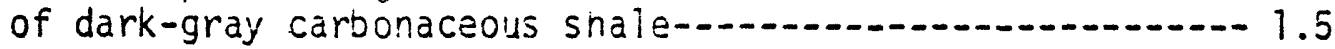

Coal, blocky; bony in upper $0.1 \mathrm{ft}$; includes at $0.1 \mathrm{ft}$. below top 0.2-ft. bed of black fissile carbonaceous

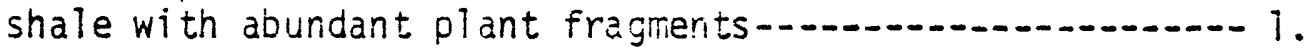

Shale, black to medium-dark-gray, fissile, carbonaceous, silty; abundant cartoriaceous plant fragments; lower contact gradational-_._. 0.5 
Sands tone, medium-gray, siabby-weathering, laminated to very thin bedded, friable, very fine grained, very silty and clayey; lower half includes beds and lenses, up to 0.1 $\mathrm{ft}$. thick, of medium- to coarse-grained sandstone and $0.05-\mathrm{ft}$. beds of sandstone with abundant coal stringers;

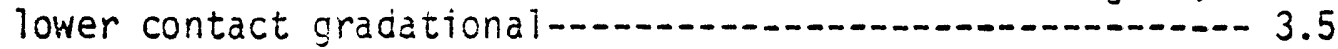

Shaie, medium- to medium-dark-gray, hackly-weathering, obscurely thin-bedded, mostly sility, clayey; at about $3 \mathrm{ft}$. below top includes medium-gray iimy siltstone concretions, about i ft. thick, with common plant fragments---10.-- 16.

Coal, bony; lower contact fairly sharp-1

Sands tone, medium-gray, poor slabby-weathering, laminated to thin-bedded, very friable, very fine grained, silty; includes lamirations of carbonaceous material; 0.5-ft. bed of medium- to medium-dark-gray shale at $1.4 \mathrm{ft}$.

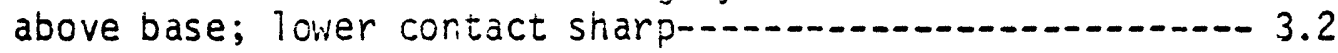

Siltstone, medium-gray, hackly-weathering, obscurely thinbedded; scattered carbonaceous plant fragments; lower

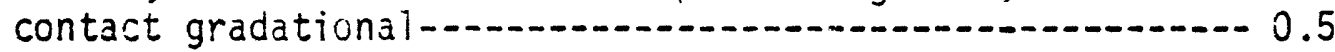

Siltstone, medium-gray to brownish-gray, platy-weathering, ledge-forming, hard, limy; abundant leaf impressions-...-.- 1.

Siitstone, medium-gray, hackiy-weathering, cbscurely thinbedded; scattered caroonaceous plant fragments; includes few $0.1-\mathrm{ft}$. ironstone nodules near middle; lower contact fairly sharp-1..- 7.3

Sandstone, medium-gray, very thin bedded to laminated, very fine graired, very silty and clayey; upper half includes interbeds of medium-gray laminated very firely sandy silts tore-1.-. 3 .

Siltstone, medium-gray, ledge-forming, hard, nodular, limy; abundant plant fragments-.................................. 0.6

Siltstone, mediumi-gray, partly iron-stzined, hackly-weathering, obscurely bedced in lower part, mostiy very thin bedded,

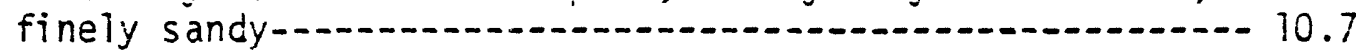

Coal, Cooper bed, blocky, platy-weathering in upper 1-2 ft.---- 5.4 Lower part of exposed rocks not measured 
Measured section 3

Location: Creek-bed and hillside exposures in Bear Canyon along upper part of Palmer Creek from SE $1 / 4 \mathrm{sec}$. 3 southward to center sec. 10, T. 6 S., R. 13 W., Seldovia C -4 quadrangie. This location is approximately the same as locality 126 of Barnes and Cobb (1959, pls. 18, 19).

Tertiary rocks - Kenai Group, Beluga Formation (upper part)

Feet

Upper part of exposed rocks not measured

Coal, (upper coal at locality 126 of Barnes and Cobb, 1959), platy-weathering; includes at $0.4 \mathrm{ft}$. above base a parting as much as $0.3 \mathrm{ft}$. thick of light-brownish-gray partly iron-stained hard clayey siltstone that weathers light-gray and contains pyroclastic(?) grains; lower contact sharp-..-

Sandstone, medium-gray, poor platy-weathering, obscurely very thin bedded, friable, very fine grained, subangular to subrounded, partly silty, siightly clayey; becomes medium-iight-gray ciayey siltstone in upper half; includes large randomly oriented coaly wood fragments in upper $0.5 \mathrm{ft} . ;$ lower contact sharp-........-. 2.

Siltstone $(3 P-72)^{*}$, medium-gray, partly iron-stained, hackly-weathering, cbscurely very thin bedded, hard, clayey; 10cally abundant carbonaceous plant fragments; few leaf impressions near top; inciudes 0.3$\mathrm{ft}$. bed of medium-dark-gray fissile carbonaceous shale about $1 \mathrm{ft}$. above base-..... 4 .

Coal, bony; lower contact sharp-a. 0.5

Siltstone, medium-gray, partiy iron-stained, very thin bedded, hard, very sandy, clayey; localiy abundant carbonaceous plant fragments; few very thin coal

stringers; lower contact gradational-a...- 2

Sands tone, medium-gray, mostly iron-stained, poor slabbyweathering, obscurely bedded, friable, fine- to mediumgrained in lower $2 \mathrm{ft}$., very fine grained in upper 1.5 ft., subangular to subrounded. slightly silty; scattered carboraceous plant fragments; lower contact sharp--..--.-- 
Shaie, black, partly iron-stained, fissile to platy-bedded, carbonaceous; coailified wood fragmerits; lower contact

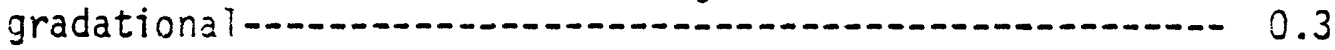

Siltstone, medium-gray, partly iron-stained, nackly-weathering, obscurely very thin becded, clayey, partiy micaceous, partiy sandy; few carbonaceous piant fragments-..........-. 5.

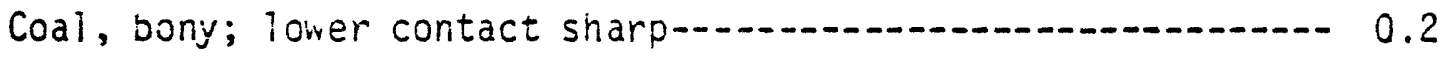

Sandstone and interbedded siltstore; sandstone, mediumgray, partly iron-stained, poor slabby-weathering, very thin bedded, friable, very fine to fine-grained, subangular to subrounced, sitty, partly ciayey; forms beds to $2 \mathrm{ft}$. thick; siltstone, nedilum-gray, nacklyweathering, cbscurely bedied, olayey; iocally includes leaf impressions and carbonaceous plant fragments;

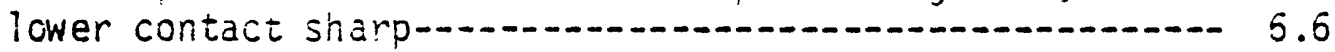

Sandstone, riediumi-gray, partiy iron-stained, poor slabbyweathering, very thin bedded, friabie, very fine to fine-grained, subangular to subrounded, silty, slightly clayey

Siltstone and interbedded sandstone; siltstone, mediumgray, blocky-weathering, coscurely bedded, clayey; sandstone, medium-gray, partly iron-stained, very f're grained, subangular to subrounded, clayey; abundant carbonaceous plant fragments; lower contact prodadiy sharp--10.-10 10.

Sandstone, medium-gray, poor slabby-weathering, obscure?y bedded, friable, very fine to fine-grained, subangular to subrounded; lower contact pooriy observed............. 3.

Siltstone and interbedded sandstore; siltstone, medilim-gray, blocky-weathering, obscurely bedded, hard, clayey, partly sandy; few carbonaceols piant fragments; sandstone, medium-gray, tinin-bedded, very fine grained, subangular, silty, clayey; restricted to loiver half of

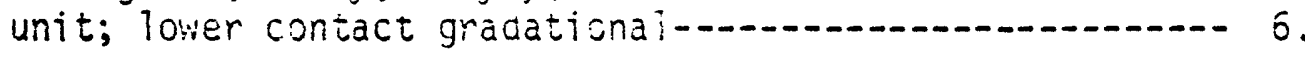


Sands tone, medium-gray, partly iron-stained, poor slabbyweathering, very thin bedded, cross-bedied in part, friable, very fine to fire-grained, subangular to subrounded; includes a 2-it. intervai of interbedded very fine grained clayey sandstone and soft cieyey siltstone with ironstone nocules about $1.5 \mathrm{ft}$. above base; a 0.5-ft. bed of medium-gray poorly friable very fine grained sandstone about $5 \mathrm{ft}$. above base; thin platy sancstone lenses in upper half; numerous micaceous very carbonaceous sancstone stringers lass than $0.1 \mathrm{ft}$. thick in upper $2 \mathrm{ft}$.; lower contact sharp and poss ibly disconformao ie

Siltstone and interbedded sandis tone; siitstone, mediumgray, platy-weathering, very thin bedied to partly laminated, clayey; few caroonaceous plant fragments; sandstone, medium-gray, partiy iron-stained, very thin bedded, friab?e, very fine to fine-grained, subanguiar, silty; becomes laminated to very thin bedded very fine grained sandstone with some carbonaceols wood material (possible roots in growth position?) in upper $1.5 \mathrm{it.}$;

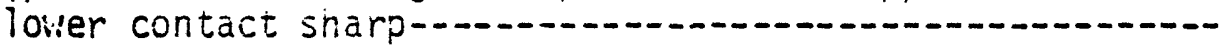

Siltstone, medium-gray, partiy iron-stained, platy-weathering, very thin bedded to partiy iaminated, clayey, partiy micaceous; few carbonaceous piant fragments; includes a 0.05-ft. medium-dark-gray fissile carbonaceous snaie about $4 \mathrm{ft}$. above base, a 0.5-ft. dark-gray to black carbonaceous shaie about 6 it. above base; few small ironstones less than $0.1 \mathrm{ft}$. thick in courses scattered throughout; leaf impressions in upper $2 \mathrm{ft}$.; lower contact gradational-a.

Sandstone and interbadded siltstore; sandstone, mediumgray, partiy iron-stained, piaty-weztnering, very thin bedded to iaminated, very fine grained, subangular to subrourided, clayey, silty; locally abundant carbonacecus piant fragments (feiv in growth position?); siltstone, similar to sandstone; ubper 1 $\mathrm{ft}$. friable very fine grained suoangular to subrounded sandstone; iower contact gradational....................... 4.6

Sandstone, medium-gray, partly iron-staired, slaboy - to platy-weathering, very thin bedded, cross-bedded, mostly friable, very fire to fine-grained, subangular to subrounded; includes many trin beds oi partly laminated rion-friable very clayey silty sandstone;

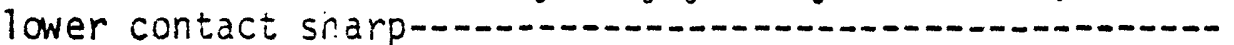


Siltstone, medium-light-gray, fiaggy- to platy-weathering, laminated to very thin bedied, sandy, ciayey, slightly limy; common caroonaceous plant fragments; lower con-

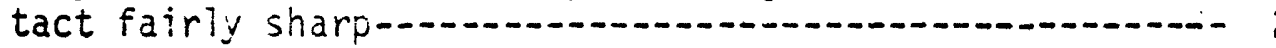

Sandstone, medium-gray, partly iron-staired, slabbyweathering, very thin bedded, cross-bedied, friable, very fine to fine-grained, sucangular; lower contact

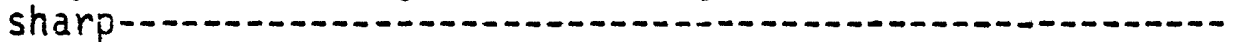

Sandstone, medium-gray, partly iron-stained in lower $1 \mathrm{ft}$, prominent olaty-weathering, laminated to platy-bedded, hard, very fine grained, subangular to subrounded, very silty in lower $1 \mathrm{ft}$., sligntiy liny; adundant carbonaceous plant fragments locally on bedaing surfaces;

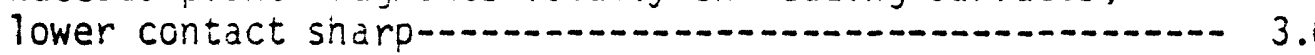

Sandstone, medilum-gray, mostly iron-stained, poor slabbyweathering, very thin bedded, cross-bedded (smallscale), friable, very fine to fine-grained, subangular to subrounced; few coalified wood fragments in lower $1 \mathrm{ft}$; inciuces few fragments oi carbonaceous shaie near base; a $0.5-f t$. jed of medium-light-gray thinly interbedded limy very fine grained sandstone and clayey siltstone in lower $1 \mathrm{ft}$.; 4 laminated very fine grained clayey sandstone beds up to $0.2-f \tau$. thick in lower 6 ft., few scattered iron-stained ciayey ienses of sands tone up to $0.1 \mathrm{ft}$. thick; lower contact sharp and

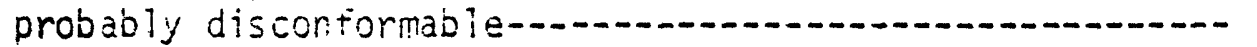

Siltstone, medium-gray, partly iron-stained, hackly- to platy-weatnering, very thin bedded to partily laminated, hard, clayey, sandy; abundant piant fragments and coalified iron-replaced plant fragments (partly in growth position?) mostly along bedding suriaces; includes at $3.5 \mathrm{ft}$. above base a $i-f t$. bed of medium- to medium-dark-gray platy-bedded silty carbonaceous shaie, with plant fragments, that grades to uncerlying and overlying siltsione; at top a 0.5-ft. bed of carbonaceous shale, similar to below, that contains locally abundant leaf impressions; iower contact gradational.....

Sandstone, redium-gray, partly iron-stained, poor slabbyweathering, osscurely bedded, friable, very fine grained, subangular to subrounded, si ity; lower con-

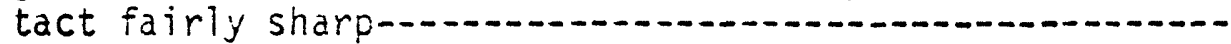


Siltstone, medium-gray, iron-stained in lower part, obscurely very thin bedded, soft, ciayey, partly sandy; abundant carbonaceous zlant fragments on bedding surfaces; lower

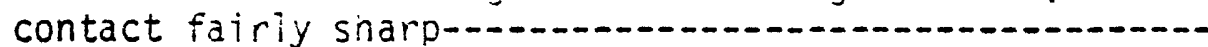

Shale, medium- to medium-dark-gray, platy-weathering, fissile to platy-bedded, partiy caroonaceous; abundant plant fragments in upper 0.3 ft.; includes bony coal stringers and woody fragments; lower contact fairiy sharp-C.

Siltstone, medium-gray, partly iron-stained in lower $7 \mathrm{ft}$, platy - to blocky-weathering, very in in bedded to 1 aminated, sandy, clayey, very ciayey in upper i ft.; some small carbonaceous plant fragments-

Shale, medium-gray, hackly-weathering, obscurely bedded, silty; sone carbonaceous plant fragments; lover contact gradational-ar

Siltstone, medium-gray, partly iron-stained, poor platvto chunky-weathering, poorly very thin bedjed to partly laminated, clayey, partly sandy; common carbonaceous plant frágments; lower contact snarp-...

Shale, dark-gray to black, platy-bedded, carbonaceous; includes bony coal stringers; ironstone noduies to 0.5

ft. thick in lower part-a

Shale, medium-gray, obscurely bedded, hard; many carbonaceous plant fragments; lower contact gradational

Siltstone, medium-gray, partly iron-stained, obscurely bedded, clayey, sandy in basal jart; many carbonaceous plant fragments; lower contact gradational-.....- 1 .

Sandstone, medium-gray, partiy iron-stained, slabby-weathering, obscurely very thin bedded, cross-bedded, mostiy friable, very fine grained, subangular, silty, clayey, very clavey in top $0.2 \mathrm{ft}$.; some carbonaceous plant

fragments; iower contact sharp-...

Shale, medium-gray, obscurely bedded, hard, silty; many carbonaceous plant fracments: inciudes ironstone nodules $0.3-\mathrm{ft}$. thick at $1.3 \mathrm{ft}$. above base; lover contact sharp- 
Sandstone, medium-dark-gray, partly iron-stained, poor platyto very thin badded, very fine grained, subangular to subrounded, very ciayey; many caroonaceous piant fragments; includes several in in very carboraceous siltstone beds; a 0.2-ft. bony coal at top; lower contact sharp-..- 1.2

Sandstone and interbedded siltstone; sands tone, mediumgray, chunky-weathering, obscurely bedded, partly friable (0.5-ft. oed $0.7 \div t$. beiow top), very fine grained, suangular, mostiy very clayey; some carbonaceous plant fragments; siltstone, medium-gray, obscurely bedded, clajey, mostly sandy; some carbonaceous piant fragments-.........................................

Sandstone, nedium-gray, partiy iron-stained, obscurely bedded, mostly friable, very fine grained, subangular, slightly siity, clayey; inciudes lew thin

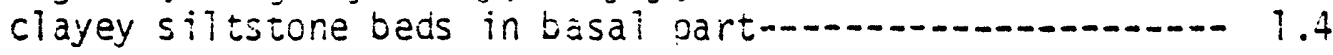

Siltstone, medium-gray, partly lightly iron-stained, hacklyweathering, iaminated to coor piaty-bedded, clayey, partiy sandy; many carbonaceous plant fragments on bedding and some normal to beading; inciudes few thin interbeds of very fine grained sardstone in lower and upper parts--.-.-

Sands tone, medium-gray, oartly iron-stained, chunky-weathering and hard in upper half, obscureiy bedded, friable in lower half, fire-grained in lower'part becoming very fine grained and very silty in upoer part, subangular, clayey; few carbonaceous plant fragments; lower contact gradationa $i$

Siltstone, medium-gray, partly iron-stained, poor platy- to very th in becded, clayey, sandy in upper $0.3 \mathrm{ft}$.; some small carbonacecus piant fragments; inciudes 4 courses of ironstone nodules up to $0.2 \mathrm{it}$. thick in lower

$3.4 \mathrm{ft} . \ldots+\ldots$

Coal, bony; iower contact sharp-................................ 0.3

Siltstone, redium-gray, partly iron-stained, poor platyweathering in part, platy - to very thin bedded, hard, clayey; aburidant carbonaceous olant fragments; upper 0.1 $\mathrm{ft}$. becorres dark-gray and cartonaceous; 10 wer contact sharp 
Shale, dark-gray to black, poorly fissile to platy-bedded, carbonaceous; includes bony coal stringers in upper

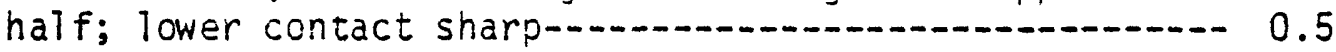

Shale, medium-gray, hackly-weathering, poorly very thin bedded, siligitily silty; many small carboraceous plant fragments -.- 1.9

Coal, blocky; includes a 0.2-ft. parting of dark-gray to black iron-stained fissiie to pcor platy-dedced carbonaceous shale at $1.3 \mathrm{ft}$. above base; iower contact

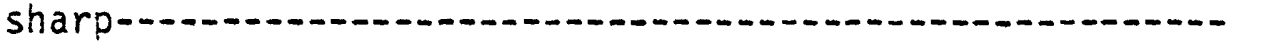

4.

Siltstone, medilim-gray, partly iron-stained, platy-wea thering, laminated to very thin becded, clayey, partiy finely sandy; many smail and some iarge coaly plant fragments and iron-replaced wood fragments (some in growth position?); one coaly stump(?) extending upward from underlying shale; includes 2 intervais, 0.5-ft. thick, of thinly interbedded siltstone and very fine grained subarigular silty sandstone at 4 and $6 \mathrm{ft}$. above base; abundant small raniomly oriented plant remains in upper $0.2 \mathrm{ft.}$

Shale, medium- to dark-gray, fissile, carbonaceous in part; abundant plant remains; inciuces bony coal lenses up

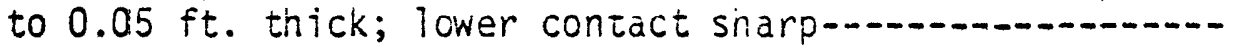

$0.1-0.3$

Siltstone, medium-gray, blocky- to poor platy-weathering, obscurely bedded, sligntly clayey; abundant plant remains; lower contact gradationai-............................... 1.8

Sandstone, medium-gray, partly iron-stained, slabby-weathering in lower part, blocky- and platy-weathering in upper part, very inin beaded and cross-bedded in lower $2.3 \mathrm{ft}$. , laminated in upeer $1.3 \mathrm{ft}$, very fine grained, subanguiar, silty; scattered carbonaceous and iron-replaced piant remains (some in growth positicn?); inciudes a few thin beds of iron-stained fine- to riedium-grained subangular to subrounded sandstone azout 2.3 it. above base; Tower

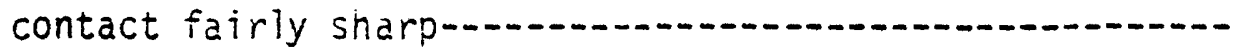


Sandstone, medium-gray, very iron-stained in lower $4 \mathrm{ft}$, very thin to thin-bedded in iower $3 \mathrm{ft}$. . cross-bedded, friable, fine- to medium-grained becoming dominantiy finegrained in upper third, suoangular to subrounded; many dark rock fraglients; incluces scattered iron-ricn stringers up to 0.1 it. thick; + beds up to $0.3 \mathrm{ft}$. thick, of mediumgray laminated to platy-jedced ciayey siitstone at 30 to $34 \mathrm{ft}$. above base-1.

Siltstone and interbedded sandstore; siltstone, medium-gray, partly iron-stained, poor cla $\because j$-bedded, clayey; plant fragments, ieaf imoressions; sandstone, medilum-gray, partly iron-stained, poor piaty-weathering, friable in part, very fine graired, suzangular silty, clayey; few carbonaceous piant iragments; forms beas to $0.3 \mathrm{ft}$. thick; 0.1-it. bed of black fissile very carbonaceous shale at top-...-

Shale, medium-gray, hackly-weathering, cbscurely bedded, silty; many caroonaceous oiant framents; many leaf impressions in upper part; vecomes dark-gray to black and very carbonaceous in middie-1...

Coal, weathered, blocky; includes a 0.5-ft. medium- to darkgray shale parting $0.5 \mathrm{ft}$. below top-

Shale $(3 p-44)^{*}$, redium-gray, dark-gray in upper $0.2 \mathrm{ft}$, poor platy - to hackly-weathering, obscureiy bedded, silty; aburiant plant fragments; lower contact gradational

Siltstone, medium-gray, partly ligitiy iron-stained, poor platy-weatnering, ooscurely oedded, clayey, sanay in lower half; abundant plant fragments; lower contact sharp-1.-

Sandstone, medium-gray, laminated in part, more friable than underlying sanastone, very fine grained, subangular to subrounded; includes carbonaceous laminations-.....- 1.4

Sandstore, medium-gray, platy - to hackly-weathering, obscurely bedded, very fine grained, subangular to subrounded, very clayey; includes several medium-gray clayey silitstone interbeds 
Siltstone, medium-light-grav, partly iron-stairied, platy- to very thin bedded, clayey, sandy; common plant fragments randomiy oriented in part; ajunaant leaf impressions in upper $0.1 \mathrm{ft}$. ; lower contact gradational-................. 3.2

Sandstone, medium-gray, partly irori-stained, platy- to nacklyweathering, pcor platy - to very thin bedded, hard, very fine graired, subanguiar, very clayey, silty; upper half becomes sandy siltstorie; Dlani fragments in upper part;

lower contact fairly shäp-.................................. 1.9

Sandstone, medium-gray, partly iron-stained, fartly platyweathering, very thin to thin-bedded, cross-bedded, very fine grained, subangular, silì, slightly clayey-........ 1.4

Sandstone, medium-gray in upper nalf, mostly iron-stained in lower nalf, poor slaboy-weathering, probabiy thinbedded and cross-bedded, frizbie, mediun- to coarsegrained, subrounded to subangular, sligntiy silty; locally ircludes at base granules, pebbies, and cobbles of crystalline rock up to 0.5 by $0.2 \mathrm{ft}$.; few lenses, less than $0.1 \mathrm{ft}$. thick, of lignt-gray saridy pyroclastic(?) siltstone and very carbonaceous sanastone; upper $1 \mathrm{ft}$. includes several coaly lenses and coal

fragments-.

Coal, biocky-...

Shale, medium-gray, platy-bedded; includes many coal stringers

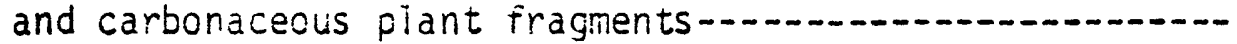

Coal, biocky

Siltstone, medium-gray, partly iron-stained, obscurely bedded, hard, clayey; many carbonaceous piant fragments randomily oriented; lower contact sharp-............................. 0.2

Sandstone, medium-gray, partiy iron-stained, obscurely very thin bedded, very fine grained, subangular to subrounded, silty, ciayej; inciudes coal fragments in lower part;

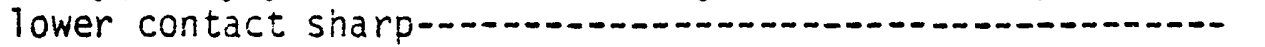

Siltstone, medium-gray, obscurely bedded, very clayey; scattered to abundant plant fragments; some leaf impressions about $3 \mathrm{ft}$. above base; includes few ironstone nodules at $4 \mathrm{ft}$. above base; few iron-stained very fine grained sandstone beds in upper $2 \mathrm{ft}$.; lower

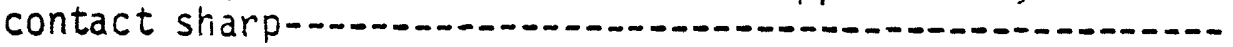


Sandstone, medium-gray, very iron-stained, obscurely thinbedded to laminated, partiy friable, very fine to finegrained, subangular to subrounded, siity; cartonaceous plant material in lower and middle parts; inciudes at base a 0.3-ft. bed of medium-gray iron-stained sandy siltstone--... 2.6

Coa1, bony; coaly wood fragments in basal part; lower contact sharp--..-...-.

Siltstone, riedilum-gray, partly iron-stained, platy- to hackly-weathering, laminated to very inin bedded in lower half, ocscurely bedded in upper half; few small carbonaceous plant fragments; includes few thin interbeds of very fine grained subangular silty sands tone;

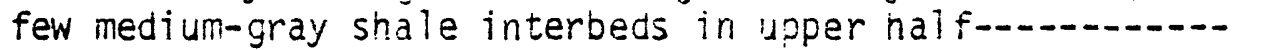

Shale, dark-gray, carbonaceous; includes bony coal (large flattened coalified logs) $-\cdots$

Siltstone, mediuri-gray, slightly iron-stained, hacklyweathering, obscurely very thin bedded, clayey, fineiy sandy; few plant fragments; lower contact sharp and un-

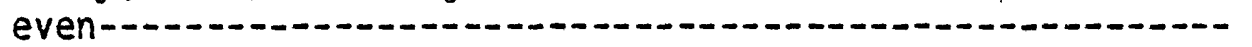

Coal, weathered, mostly bony; includes flattened logs in basal part; a 0.4-ft. bed of biack carbonaceolis shaie $0.8 \mathrm{ft}$. above base; lower contact snarp and wavy-...-.-.-

Siltstone, medium- to medium-1ight-gray, iron-stained, platy- to uneven-weathering, laminated in upper part, hard, clayey; locally common plant fragments; leaf impressions in basal $1 \mathrm{ft}$; includes very fine grained subanguiar silty clayey sandstone interbeds in ucper $5.2 \mathrm{ft}$.; upper $1 \mathrm{ft}$. includes randomiy oriented large irregular coal stringers and fragments; lower contact gradational--..-.

Siltstone, medium- to dark-gray, platy-bedded, carbonaceous in lower half: abundant piant fragments and coal stringers

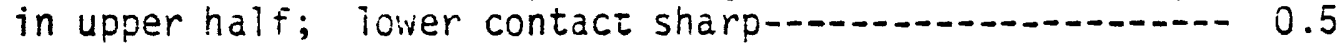

Sandstone, medium-gray, iron-stained, platy- to unevenweathering, very tnin bedced, hard, very fine grained, subangular, si? ty, clayey; locally abundant plant fragments ---..-- 
Siltstone, medium-gray, parily iron-stained, platy-bedded, clayey, partly sandy; locally abundant plant fragments and leaf inipressions; iower contact gradationai-_........-. 1.1

Siltstone, dark-gray, platy-bedded, clayey, carbonaceous; abundant plant framents; scatterea coaly stringers;

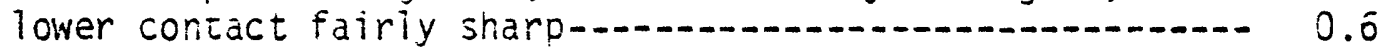

Sandstone, medium-gray, very iron-s tained, platy- to very thin bedded, very fine grained, subangular to subrounded, silty, very clayey; locally abundant carbonaceous pient fragments; 0.5-ft. bec of hard ironcemented(?) ciayey siltstone at base; includes siltstone chios 10cally; upfer half includes interbeds of friable sandstone and hard ciayey sancstone; lower contact sharp--...-...-

Siltstone, medium- to dark-gray, partly iron-stained, platybedded in part, nard, clayey, carbonaceous in part; abundant carbonaceous plant iraments (mostly leaves); includes bony coal stringers at base; iower contact sharp-..-.

Sandstone, medium-gray, partly iron-stained, platy-weathering, laminated, hard, very fine gra ined, subangular to subrounded, very silty, clayey; localiy adundant carbonaceous iaminations interbedded with medium-gray slabby-weathering obscurely bedded friable very fine grained subrounded sancstone; about equal amounts of both sandstone types in lower half forming beds $1-1.5$ foot thick; laminated sandstone becomes dominant in upper half

Sandstone, medium-gray, iron-stained, obscurely bedded, friabie, very iine to iine-grained, sudangular to

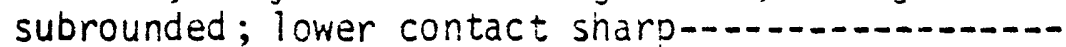


Siltstone, medium-gray, blocky-weathering in lower haif, platy-weatnering in upper nalf, partly coscurely bedded, laminated in upper haif, clayey, sandy in upper haif; leaf impressions and rancomly oriented coaly fragments (twigs) in upper half; includes 0.1-it. ironstone nodules about $1.5 \mathrm{ft}$. above base- 3.6

Shale, medium-dark-gray to black, fissile, hard; abundant carbonaceous plant fragments- 1.

Coal, platy-weathering; some fusain(?) films_- 1.5

Coal, bony; interbedded with medium-dark-gray carbonaceous

shale; lower contact snarp-... 0.1

Sandstone, medium-gray, slabby-weathering, obscurely

laminated to very thin bedded, cross-bedued, friable, hard in port, very fine grained, subangular to subrounded, silty, partiy clayey, micaceous in upper 0.9 ft.; abundant plant fragments in upeer $0.9 \mathrm{ft}$; inciudes mediun-gray clayey. siltstone interbeds up to $0.2 \mathrm{ft}$. thick; lower contact fairly sharp-

Siltstone, medium-gray, partly iron-stained, hackiyweathering, obscureiy bedded, probably verv thin bedded, hard, clayey; few piant fragments; includes medium-gray hard shale interbeds wi in abundant plant fragments in lower 2 ft.; slightly limy ironstone nodules $0.2 \mathrm{ft}$. thick at $1 \mathrm{ft}$. below top; lower contact gradational- 
Sands tone, medium-gray, slightly bluish when wet, slabbyweathering, obsclireiy thin-bedded, partly laminated about $6 \mathrm{ft}$. above base, very fine to fine-grained, subangular to slibrounded, silty, clayey; no carbonaceous plant fragments seen; includes interbeds, up to $0.3 \mathrm{ft}$. thick, of medium-gray sandy clayey silts tone with scattered carbonacecus piant fragments in lower $2 \mathrm{ft}$. and upper $6 \mathrm{ft}$.

Siltstone and interbedded sandstone; siltstone, medium-gray, partiy iron-stained, obscureiy bedded, hard, clayey; few carbonaceous plant fragmerits; sandstone, medium-gray, partiy iron-stained, iriable, very fine to fine-grained, subangular to subrounded, silty, clayey; beds $0.2-0.5$ ft. thick-........... 2.4

Covered interval26.3

Sandstone, medium-gray, partly iron-stained in upper half, slabby-weathering, friable, fine-grained, some medium grains in lawer part, suorounded to subangular; abundant dark rock fragments; upper $7 \mathrm{ft}$. includes interbeds, up to $1 \mathrm{ft}$. thick, of sandy clayey siitstone with scattered carbonaceous piant fragments; lower contact sharp-...-.-.-

Siltstone, medium-gray, partly iron-stained, obscurely bedded, clayey, partiy sandy in upper $3 \mathrm{ft}$.; many small plant fragments; inciludes at top ironstone nodules, up to $0.35 \mathrm{ft}$. thick, containing deundant randomly oriented plant fragments; lower contact gradational-......-...-.-. 4.5

Shale, medium-gray, partly iron-stained, obscurely bedded, silty; abundant randomly oriented plant fragments; inciudes near middie ironstone nodules, up to $0.2 \mathrm{ft}$. thick, with abundant piant fragments roughly parallel to bedding-...-...-

Shale, dark-gray to black; abundant carbonaceous plant material on bedding surfaces; upper half very impure bony coal---- 0.8

Shale $(\underline{3 P-25)}$ *, medium-gray, weathered, obscurely bedded;

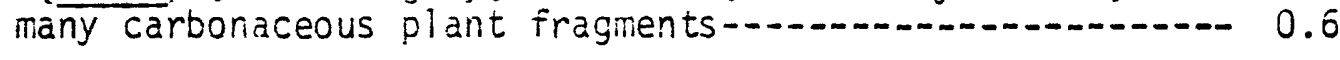

Coal, weathered, blocky 
Siltstone, medium-gray, partly iron-stained, hackly-weathering, obscurely very thin bedded, clayey; some carbonaceous plant fragments; includes some sandstone interbeds similar to underiying unit; at top a 0.3-ft. bed of medium-dark-gray silty shale with abundant carbonaceous plant fragments; lower contact orobably gradational-_..-...-

Sandstone, medium-gray, partiy iron-stained, platy- to thinbedded, hara, very fine grained, subangular to subrounded, silty, clayey; some carbonaceous piant fragments; inciudes silistone interbeds in upper $1 \mathrm{ft......--} 3.4$

Shale, black, fissile to platy-bedded, carbonaceous; abundant carbonaceous plant material; lower contact sharp-......... 0.1

Shale, medium-gray, obscurely bedded, hard, silty; some carbonaceous plant fragments; $0 . j-f t$. bed of siltstone

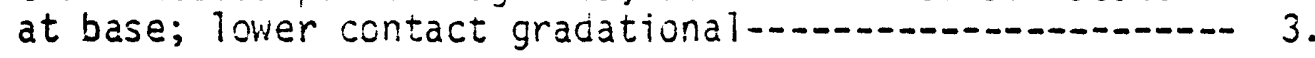

Sandstone, mediun-gray, partiy iron-stained, very thin bedded to partly laminated, cross-bedded, very fine to finegrained, subangular to subrounded, silty, clayey; some carbonacecus 1 aminations; lower contact sharp-............-

Shale, medium-dark-gray, fissile to platy-bedded, hard, silty; abundant plant fragments on becding surfaces; includes a 0.2-ft. bone coai near middle; large coalified logs in

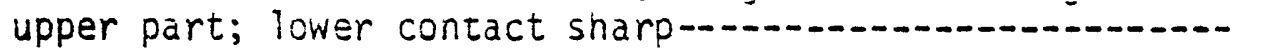

Sands tone, medium-gray, chunky- to hackly-weathering, partly laminated, mostiy obscurely very th in to thin-bedded, partiy friable, very fine grained, subangular to subrounded, silty, clayey; upper haif becomes mostiy sandy siltstone with some carbonaceous piant fragments; lower contact gradaticnal-_...........

Siltstone, medium-gray, locally iron-stained, obscurely bedded, clayey; sone carbonaceous olant fragments locally; includes ironstone nodules, up to $0.5 \mathrm{ft}$. thick, near iniddle and at top; few interbeds of mediumgray shale and very fine grained sandstone-............. 17.

Covered interval-a. 6.2 
Siltstone, medium-gray, obscurely thin-bedded, clayey, partly sandy in upper half; locally abundant carbonaceous plant fragments; inciudes a 0.7-ft. bed of medium-1ignt-gray friable very iine grained subangular silty sandstone at $1.5 \mathrm{ft}$. above base; scattered ironstone nodules, up to $0.2 \mathrm{ft}$. thick, in upper

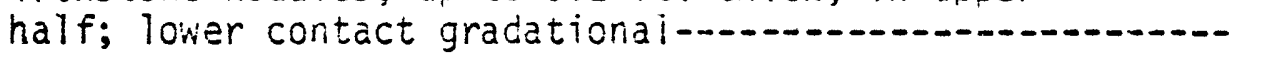

Siltstone, medium-gray to brownish-gray, partly iroristained, blocky-weathering, laminated to very thin bedded, clayey, partly fine?y sandy; few carbonaceous plant fragments; inciudes hard limy concretions in

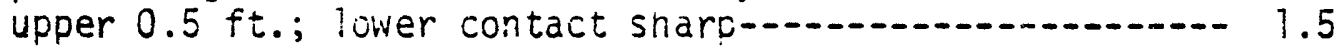

Sandstone, medium-gray, partly iron-stained, obscurely very thin to thin-bedded, friable, very fine to finegrained, subrounded to subangular; includes shale lenses uo to 0.05 by $0.3 \mathrm{ft}$. in lower $1 \mathrm{ft}$; 10 wer

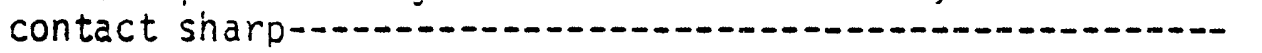

Shale, medium-gray, obscurely very thin bedded; lccally abundant plant fragments; includes ironstone nocules, $0.1 \mathrm{ft}$. thick, at $3 \mathrm{ft}$. above base; interbeds of friable very fine grained subangular sandstone in upper $0.5 \mathrm{ft} . ;$ lower contact fairly sharp................ 4.6

Siltstone, medium-gray to brownish-gray, locally strongly iron-stained, platy - to uneven-weathering, very thin bedded, clayey; lower contact fairiy sharp-..........-. 2.5

Sandstone, medium-gray to brownish-gray, slightly ironstained in upper $0.5 \mathrm{ft}$., very in in bedded, very fine grained, subangular, very silty, very clayey; abundant carbonaceous piant fragments; includes 2 thin beds of friable sandstone in upper i it.; lower contact fairly

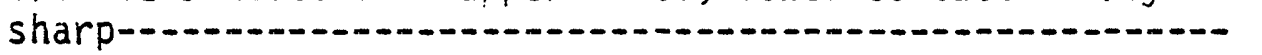

Sands tone, medium-gray, mildly iron-stained at top, obscurely bedded, friable, very fine to fine-grained, subangular to subrounded, siity; no plant fragments

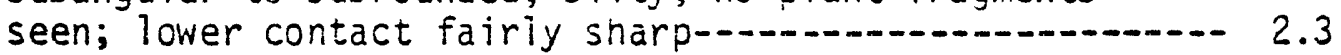

Shale, medium-gray, slightly iron-stained, small-chunkyweathering, obscureiy very thin bedded, silty; few carbonaceous plant fragments; includes interbeds of medium-gray silts tone in upper nalf-........................ 5.1

Covered interval-a. 


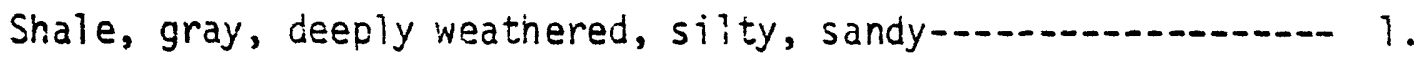

Coal

Shale $(3 P-i 5)^{*}$, medium-gray, hackly-weathering, platy- to thin-bedded, siightiy silty; abundant plant fragments-.-- 3.3

Coal, blocky; includes a 0.3-ft. gray shale parting at 2.2 $\mathrm{ft}$. below top and a $0.1-\mathrm{ft}$. gray shale parting $1.1 \mathrm{ft}$. below top; lower contact sharp and gentiy rolling-......- 5.6

Siltstone, medium-gray, partly iron-stained, hackly-weathering, clayey, finely sandy; comon plant fragrients; includes at base about $i-f i$. bed of inedium-dark-gray very thin to platy-bedded sandy carbonaceous siltstone; $1-f t$. bed of medium-light-gray friable very fine grained suvangular to subrounded silty sandstore at $2.5 \mathrm{ft}$. above base; lower contact gradational-.........

Sandstone, medium-gray, partly iron-stained, slabby- to hackly-weathering, very thin to platy-bedded, partly friable, very fine grained, subangular, silty; becomes more silty and clayey upward; inciudes friable zones up to $1 \mathrm{ft}$. thick in middle; lower contact gradational--. 5.

Shale, medium-gray, partly iron-stained, fissile to platybedded in lower half, silty; abundant carbonaceous plant fragrents in lower half becoming less common in upper half; includes at ton 0.6-ft. hard liny siltstone concretion with few carbonaceous piant fragments - -

Siltstone, medium-gray, hackly- to poor-platy-weathering, thin- to platy-bedded, very clayey; common plant fragments; includes laminations and very thin beds of medium-gray very fine grained sands tone; lower contact gradational

Sandstone, medium-gray, partly iron-stained, probably hackly-weathering, obscurely bedded to partly laminated, very fine grained, subangular, silty, clayey; few carbonaceous plant fragments-......-. 2

Covered interval; probably sandstone-........................... 2.

Shale, dark-gray, poci platy-weathering, fissile to olatybedded, carbonaceous; abundant carbonaceous plant fragments -...-...-. 
Coat, blocky-

Sandstone, medium-gray, partly iron-stained, poor platyweathering, very thin bedded to laminated, crossbedded, hard, very fine grained, subangular to subrounded, silty, very clayey; common small carbonaceous plant fragments and few randomiy criented large coai fragments; incluaes few ironstone nodules in upper 1

ft.-........-

Covered interval-_.

Coal, platy-weathering in lower part-1.5

Silts tone, medium-gray, hackly-weathering, obscurely bedded, hard, clayey, partly sandy; common carbonaceous plant fragments --

Covered interval-and

Silts tone, medium-gray, partly iron-stained, hackly-weathering, obscurely very thin to thin-bedded, clayey, sandy and micaceous in upper half; locally abundant carbonaceous plant fragments; includes at base a 0.4-ft. bed of dark-gray carbonaceous shale and a similar 0.6$\mathrm{ft}$. bed $2.2 \mathrm{ft}$. above base (contacts of carbonaceous shale beds are gradational); a 0.2-ft. ironstone at top-- 5 .

Coal, bony; includes black carbonaceous shale-................. 0.3

Shale, medium-gray, partly iron-stained, obscurely bedded, hard; abundant carbonaceous plant fragments-..........-. 0.4

Shale, dark-gray, very carbonaceous; abundant plant fragments; includes abundant interbedded bone coal; lower contact sharp-..-

Siltstone, medium-gray, strongly iron-stained in places, hackly-weathering, obscurely very thin bedded, partly finely sandy, clayey, more shaly and hackly-weathering in upper $1 \mathrm{ft}$.; few large flattened coaly wood fragments in upper $1 \mathrm{ft}$. ; includes ironstone nodules, up to $0.3 \mathrm{ft}$. thick, about $1.5 \mathrm{ft}$. above base; $0.3-\mathrm{ft}$.

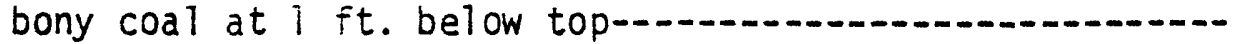

Shale, medium-gray, uneven-weathering, obscurely platy-bedded, slightly silty; abundant carbonaceous plant fragments; includes a 0.2-ft. bed of dark-gray carbonaceous shale about $2 \mathrm{ft}$. above base; lower contact gradationa $1 . . . . . . . .-$ 
Siltstone, medium-gray, slightiy iron-stained, hacklyweathering, obscurely very thin bedded to partly laminated, clayey; common carbonaceous plant fragments; includes a 2-ft. bed of medium-gray laminated hard very fine grained subangular ciayey sandstone about $1.5 \mathrm{ft}$. below top; probably contains ironstore noduies (none seen)

Coal, blocky, weathered0.8

Shale $(3 P-3)^{\star}$, medium-gray, obscurely bedded; some carbonaceous plant fragments; upper $0.2 \mathrm{ft}$. becomes darkgray fissile very carbonaceous shale-.................... 0.6

Shale, black, fissile-weathering, very carboraceous-........-. 0.2

Coal, Cabin bed, bony, platy-weathering, mostly blocky; scattered amber grains; includes a $0.4-\mathrm{ft}$. bed of medium-dark-gray to black silty carbonaceous shale with many coal stringers at $0.35 \mathrm{ft}$. above base-.........- 1.85

Siltstone, medium-gray, partly iron-stained, hackly-weathering, poor platy- to very th in bedded, clayey; few smail plant fragments; lower contact sharp-

Shale, dark-gray to black, fissile- to platy-weathering, platy-bedded, very carbonaceous; abundant plant fragments; includes about $0.1-\mathrm{ft}$. bed of bony coal near

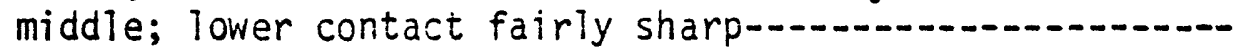

Siltstone, medium-gray, hackly-weathering, poor platyto thin-bedded, clayey; many carbonaceous plant fragments in upper two thirds; lower contact con-

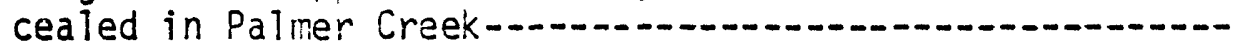




\section{Measured section 4}

Location: Hillside and creek-bed exposures in large unnamed canyon about I mile northeast of Bear Canyon near center of sec. 2, T. 6 S., R. 13 W., Seldovia C-4 quadrangle. This location is approximately the same as locality 127 of Barnes and Cobb (1959, pls. 18, 19). The youngest beds are exposed at the head of the canyon.

Feet

Tertiary rocks-Kenai Group, Steriing Formation

Upper part of exposed rocks not measured

Shale $(4 P-30)^{*}$, medium-gray, partly iron-stained, platy- to hackly-weathering, obscurely bedded, clayey; abundant carbonaceous plant fragments-.-.+

Coal, Fletcher bed, platy-weathering, impure, mostly flattened coalified logs and large wood remains; lower contact.

fairly sharp

Sandstone, medium-gray, partly iron-stained, platy-weathering, platy-bedded to partly laminated, partly friable, very fine grained, subangular, mostly clayey, very silty; locally common carbonaceous piant fragments, some plant fragments oriented perpendicular to bedding; includes four interbeds up to $1.5 \mathrm{ft}$. thick of mediumgray partly platy-bedded friable very fine grained sandstone; four interbeds less than $1 \mathrm{ft}$. thick of medium-gray partly iron-rich shale $(4 P-29) *$ with abundant plant fragments and locally abundant leaf impressions (three beds in upper half, one in lower

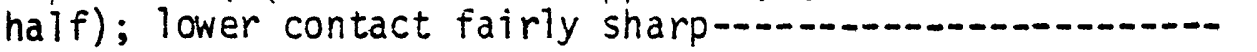

20.

Sandstone, medium-gray, medium-light-gray-weathering, uniformly light-brown iron-stained, weathering to rounded slabby steep knobby slopes, poor cliffforming, very thin to thin-bedded, cross-bedded, friable, fine- to medium-grained, subangular to subrounded, silty; includes few shale flakes at base; few interbeds of medium-gray poor fissile- to platy-weathering platy-bedded to laminated very fine grained clayey sandstone with common carbonaceous laminations;

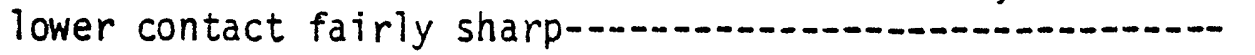


Sandstone, medium-gray, partly iron-stained, poor fissileto platy-weathering, platy-bedded, locally laminated, very fine grained, subangular, clayey, very silty; locally abundant carbonaceous plant fragments; includes common carbonaceous laminations; lower contact fairly sharp-...

Sandstone, medium gray, iron stained, medium-1ight-grayweathering, steep rounded slabby knobby slope-forming, poor cliff-forming, very thin to thin-bedded, crossbedded, friable, fine- to coarse-grained in basal part becoming mostly fine- to medium grained above $10 \mathrm{ft}$. above base, subangular to subrounded, silty; scattered large coalified wood fragments in lower $5 \mathrm{ft}$.; includes medium-gray siltstone clasts in lower $3 \mathrm{ft}$.; interbeds up to $2 \mathrm{ft}$. thick between 5.5 and $10 \mathrm{ft}$. above base of platy to laminated very fine grained sandstone; banded iron-stain pattern suggestive of soft-sediment flowage or possible ground-water action; lower contact fairly sharp and even-1..

Sandstone, medium-gray, medium-1ight-gray-weathering, locally iron-stained, partly friable, very fine to fine-grained, subangular to subrounded, silty; scattered pebbles of hard rock; includes at top $0.5-\mathrm{ft}$. bed of conglomerate composed of granules and pebbles of hard rock and pebbles and cobbles of medium-gray silty sandstone and carbonaceous shale; includes medium-grained sandstone bed of carbonaceous wood fragments; lower contact sharp, probably disconformity-.

Beluga Formation (upper part)

Siltstone, medium-gray, small chunky-weathering, obscurely bedded, clayey, sandy in lower part; some carbonaceous plant fragments partly oriented perpendicular to bedding;

lower contact gradational 0.8

Sandstone, medium-gray, poor platy-weathering in upper twothirds, obscurely very thin bedded, friable in lower part, fine-grained in lower part becoming very fine grained in upper part, subangular, silty; common carbonaceous plant fragments oriented perpendicular to bedding in upper two-thirds; Tower contact sharp-....... 1.6

Siltstone, medium-gray, poor platy-weathering, poor very thin bedded, clayey, sandy at base; locally abundant carbonaceous plant fragments 
Sandstone, medium-gray, partl $y^{\prime}$ iron-stained, slatby-weathering, obscurely bedded, friabie, fine-grained, sub-

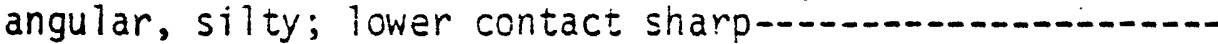

Shale, medium-gray, obscurely bedded, subconchoidally fracturing, clayey; some small carbonaceous plant

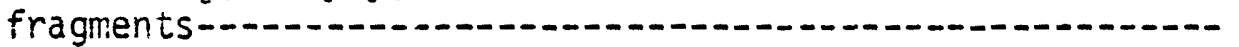

Shale, dark-gray to black, silty, carbonaceous; coalified

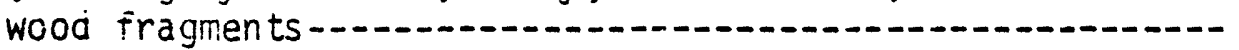

Coal, fairly blocky-_.-.

Siltstone, medium-gray, cbscurely bedded; many randomly oriented carbonaceous plant fragments-_................. 0.9

Shale, dark-gray to black, platy-waathering, fissile to platy-bedded, silty, carbonaceous; abundant smal1 and fairly large carbonaceous piant fragments, some

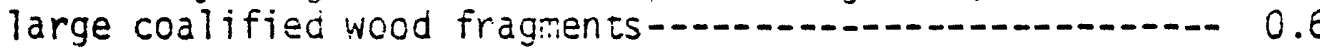

Siltstone, medium-gray, obscurely bedded; common carbonaceous plant fragmients; lower contact gradational-.....- 0.4

Sands tone, medium-gray, slabby-weathering, obscurely bedded, mostly friable, very fine to fine-grained, subangular,

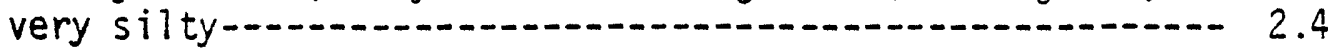

Siltstone, medium-gray, obscurely bedded; some carbonaceous plant fragments, feiv leaf impressions; becomes very fine grained very clayey sancstone in upper $0.3 \mathrm{ft}$. ;

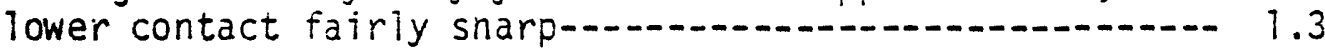

Sandstone, medium-gray, partly iron-stained, poor platyweathering, poor piaty - to very thin bedaed, very fine grained, subangular, very silty; some carbonaceous plant fragments, leaf impressions in part-...............-. 2

Siltstone and interbedded sands tone; siltstone, mediumgray, poor platy-weathering, obscurely bedided, clayey; many carbonacecus plant fragrients; sands tone, mediumgray, poor platy-weathering, coscurely bedded, very fine grained, slbangular, silty, very clayey; some

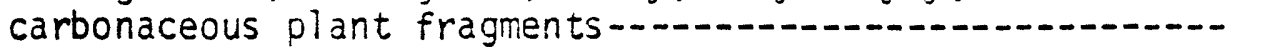

Shale, dark-gray to black, ooor platy-bedded, silty, carbonaceous; abundant small and few large carbonaceous plant fragments; lower contact gradational-................- 
Siltstone, medium-gray, poor platy-weathering, obscurely bedded, clayey; many small carboraceous plant frag-

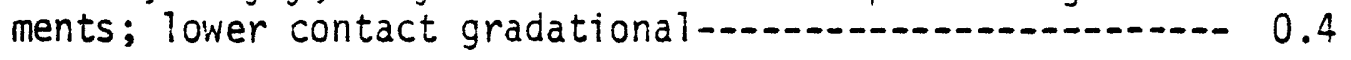

Sandstone, medium-gray, slabby-weathering, obscurely bedded, partly friable, very fine grained, subangular, very silty; carbonaceous plant fragments in upper part; loker contact gradational-_-_.-.-. 1.8

Siltstone and interbedded sandstone; siltstone, mediumgray, poor platy-weathering, obscurely bedded, clayey; many plant fragments; sands tone, medium-gray, very fine grained, subangular, silty, clayey; forms beds up to $0.6 \mathrm{ft}$. thick; unit inciudes at base $0.1-\mathrm{ft}$. bed of dark-gray to black fissile carbonaceous snale; lower

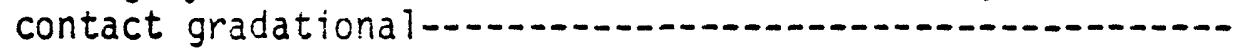

Sandstore, medium-gray, obscurely bedded, friable in lower part, very fine grained, subangular, silty; many piant fragments in upper part; lower contact sharp-...-....-.- 1.5

Siltstone, medium-gray, poor platy-weathering, obscurely bedded, clayey, sandy in upper part; many plant frag-

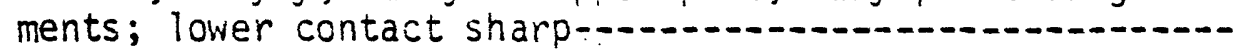

Shale, dark-gray to black, some brownish-gray, mostly platybedded, silty; abundant carbonaceous material; inciudes

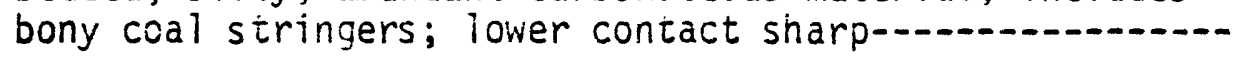

Siltstone, medium-gray, partiy iron-stained, poor platyweathering, platy - so poor very th in bedded, sandy, clayey; abundant leaf impressions 6.5 to $8.5 \mathrm{ft}$. above base; includes 2-ft. bed of medium-gray very fine grained

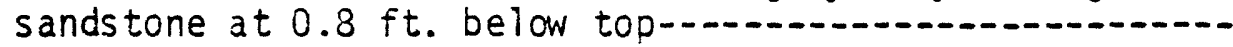

Shale, dark-gray to black, fissile- to platy-weathering, platy-bedded, silty, carbonaceous; abundant plant fragments-1-1.--

Siltstone, medium-gray, poor platy-weathering, platy- to poor very thin bedded, some lamination in lower part. clayey; abundant carbonaceous plant fragments; includes few thin beess of very fine grained sandstone in basal $1 \mathrm{ft}$. 
Shale, medium-gray, poor piaty-bedded, very silty; abundant plant fragments, few large coalified wood fragments near base; includes few calcareous ironstone nodules up to $0.2 \mathrm{ft}$. thick about $2.4 \mathrm{ft}$. above base-.........- 3 .

Coal and interbedded shale; coal, bone; shale, dark-gray to black, carbonaceous; includes many coal stringers....- 0.2

Shale $(4 P-16)^{*}$, medium-gray, iron-stained, obscurely bedded, subconchoidally fracturing, clayey; many carbonacecus plant fragments

Coal, platy-weathering-_..... 1.

Shale, dark-gray to black, fissile- to platy-bedded, carbonaceous; includes many coal stringers; lower contact sharp-1..-...-..-.

Siltstone, medium-gray, partly iron-stained, platyweathering, cbscureiy bedded, clayey; many randomily oriented fine plant imprints; lower contact sharp--------- 2.

Shale, dark-gray to black, fissile- to platy-bedded, carbonaceous; abundant carbonaceous plant fragments; includes many small coal stringers; lower contact sharp---- 0.8

Siltstone, medium-gray, poor platy-weathering, poor platyto very thin bedded, partly sandy; abundant plant imprints in basal part and scattered above; includes thin interbeds of very fine grained subanguiar clayey sandstone; interval of very fine grained sandstone between 20 and $26 \mathrm{ft}$. above base; lower contact probably gradational

Siltstone, medium- to medium-dark-gray, poor platy-bedded, clayey; abundant plant imprints on bedding-............-- 0.6

Coal, blocky; includes interbeds of dark-gray carbonaceous shale and bony coal in upper $0.4 \mathrm{ft.}$

Sandstone and interbedded siltstone; sandstone, medium-gray, platy-weathering, very thin bedded, very fine grained, subangular, silty; siltstone, medium-gray, platyweathering, very thin bedded, partly sandy; locally

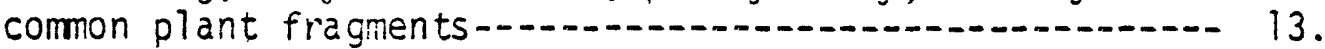

Coal, bone-1. 0.2 
Siltstone and interbedded sandstone; siltstone, mediumgray, platy-weathering, very thin bedded to partly laminated in upper half, sandy in lower $5 \mathrm{ft}$; ; locally common plant iracments, large coalified wood fragments in lower $2 \mathrm{ft}$. ; sands tone, medium-gray, platy-weathering, very thin bedded to partly iaminated, very fine grained, subangular, silty; unit inciudes $0.05-\mathrm{ft}$. beds about $15 \mathrm{ft}$. above base of dark-gray carbonaceous shale with bony coal stringers; lower contact fairly sharp-......... 28.

Sandstone, medium-gray, slabby-weathering, friable, fineto medium-grained, scattered coarse grains in basal part becoming fine-grained above $5 \mathrm{ft}$. above base, subangular to subrounded; includes large carbonaceous wood remains; iron-cemented carbonaceous stringers; lower contact sharp and possibly disconformable-......... 13.5

Shale, brownish-gray, poor fissile to platy-bedded, partly carbonaceous; abundant small carbonaceous plat fragmenis; includes many bony coal stringers; lower contact sharp..... 1.5

Siltstone, medilim-gray, partly iron-stained, platy- to poor flaggy-weathering, very thin bedded, poorly fissile and shaiy in lower $1 \mathrm{ft}$.; abundant carbonaceous plant fragments in lower $1 \mathrm{ft}$. and upper $4 \mathrm{ft}$.; inciudes near top some beds of brownish-gray siltstone with abundant

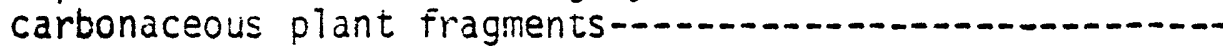
blocky-about

Silts tone, medium-gray, partly iron-stained, platy-weathering, laminated to very thin bedded, very clayey in upper $0.5 \mathrm{ft} . ;$ locally abundant small plant fragments, abundant small carbonaceous plant fragments in upper $0.5 \mathrm{ft}$.; includes few carbonaceous films and stringers; lower contact sharp-...- 4

Coal, platy-weathering, impure-1.

Sandstone, medium-gray, slabby-weathering, locally cliffforming, very thin to thin-bedded, cross-bedded with sets up to $3 \mathrm{ft}$. thick, mostiy friable, fine- to mediumgrained with scattered coarse grains in lower part becoming mostly fine-grained in upper $10 \mathrm{ft}$., subangular to subrounded, silty; few large coalified sood fragments in lower $5 \mathrm{ft}$., at $14 \mathrm{ft}$. above base, and at about $20 \mathrm{ft}$. above base; includes 0.2-ft. lenses of very thin bedded to laminated silts tone between 3 and $10 \mathrm{ft}$. below top; 3-ft. bed at top of medium-light-gray nackly-weathering sandy siltstone with common plant fragments; lower contact sharp and possibly disconformable.................... 
Sandstone, medium-gray, uneven-weathering, partly laminated, very fine grained, subangular, very silty; abundant plant remains; lower contact sharp-.............. 0.5

Interbedded shale and coal; shale, dark-gray, fissile, carbonaceous; abundant small plant fragments; shale $(4 P-6) *$, medium-gray, obscurely bedded; abundant small plant remains; coal, bony; lower contact

fairly sharp-.....

Sandstone, medium-gray, slabby-weathering, obscurely bedded, very fine grained, subangular, very silty; locally abundant smail carbonaceous plant fracments, few large coalified wood fragments rear top; includes at top 0.3-ft. bed of siltstone with abundani piant

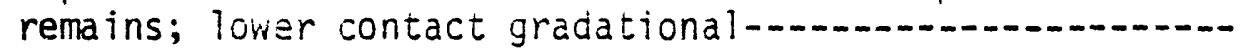

Siltstone, medium-gray, partly iron-stained, poor platy- to hackly-weathering, obscureiy inin-bedded, clayey; common smail carbonaceous plant fragments; lower contact gradationa i-........

Coal, weathered, bony; includes interbeds of dark-gray carbonacecus snale and bony coal in upper $0.1 \mathrm{ft}$.; lower contact sharp-a.

Siltstone, medium-gray, iron-stained (mostly in lower nalf), poor platy - to hackly-weathering, obscurely very thin bedded, clayey (upper haif); cormon small carbonaceous plant fragments in upper haif, large coalified wood remains in 0.2-ft. interval in middle; includes few thin shaie interbeds in upeer half; lower contact gradational-1-.

Sandstone, medium-gray, mostly platy-bedded, friable in middle part, very fine grained, subangular, very clayey in upper $0.5 \mathrm{ft}$., very silty; abundant carbonaceous plant fragments in upper $0.5 \mathrm{ft}$.; lower contact sharp-_.

Shale, medium-gray, mostly iron-stained, shard-like-weathering, obscurely bedded, very silty; some carbonaceous plant fragments; includes at top $0.5-\mathrm{ft}$. bed of siltstone with gradational lower contact-..................... 1.6

Coal, weathered, fairly blocky for most part; lower contact sharp-1.-. 
Siltstone, medium-gray, poor platy- to obscurely bedded, very sandy in lower part, partly clayey; scattered carbonaceous plant fragments in lower part, abundant randomly oriented carbonaceous plant fragments in upper part; large coalified wood fragments oriented at high angle to bedding at base; lower contact gradationa

Sandstone, medium-gray, obscurely bedded, platy - to very thin bedded in lipper $i \mathrm{ft}$., friable, very fine to fine-grained, some medium grains in lower part, sub-

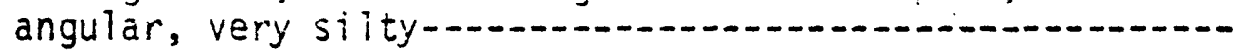

Coal, weathered, probably bony in middle part; ir.cludes at $0.1 \mathrm{ft}$. below top a $0.4-\mathrm{ft}$. bed of redium-gray poorly bedded silts tone with brownish tint and many carbo-

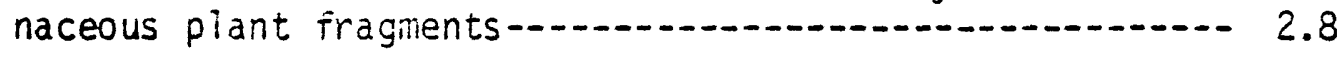

Siltstone, medium-gray, dark-gray in upper $0.1 \mathrm{ft} ., \mathrm{ob}-$ scurely bedded, mostly clayey, partly sandy; many randomly oriented carbonaceous plant fragments; lower contact gradationai--..-...- 1.

Sandstone, medium-gray, obscurely bedded, mostly friable, very fine grained, subangular, silty; lower contact sharp-_... 1

Shale, medium-gray, obscurely bedded, sandy, clayey-......-- 0.8

Coal, fairly blocky; includes at $0.8 \mathrm{ft}$. above base a $0.3-\mathrm{ft}$. parting of brownish-gray silts tone with

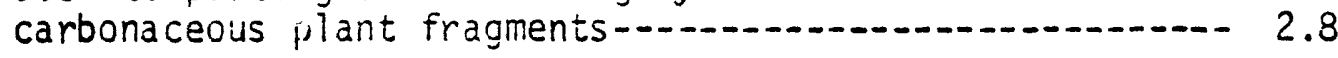

Note: A fairly high waterfall is supported by the lower three coal beds and interbedded rocks described above.

Lower part of exposed rocks not measured 


\section{Measured section 5}

Location: GUlly exposure in head of unnarred canyon in $\mathrm{VE} 1 / 4 \mathrm{NE} 1 / 4$ sec. 2, T. 6 S., R. 13 W., Seldovia C-4 quadrangle. Top of section is about 14 feet beiow canyon rim adjacent to Skyiine Drive. This location is the same as locality 128 of Barnes and Codb (1959, pls. 18, 19).

Feet

Tertiary rocks --Kenai Group, Sterling Formation

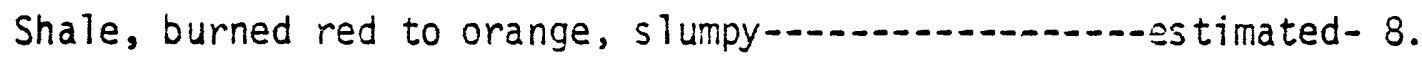

Coal, coal ash, carbonaceous shaie, bone coal, and yellow to brownisin-orange burned shaie; slumby; probably represents a 3-5-ft. coal bed with several partings

Shale, dark-gray, poor fissile to platy-bedded, carbonaceous; abundant coal films; upper haif grades to very bony coal;

lower contact gradational-_. 0.5

Shale $(5 P-29) *$, medium-gray, local ledge-forming, poor fissile to poor platy-bedded, clayey; abundant smali carbonaceous plant fragments-....

Coal and interbedded carbonaceous siltstone; lower contact sharp-1. 0.2

Siltstone, medium-gray, obscurely bedded; common carbonaceous plant fragments, mostly randomiy oriented; lower contact fairly sharp-a.- 1.4

Sandstone, medium-gray, platy-weathering, laminated to very thin bedded, friable to very friable, very fine grained subangular, very silty; iccaily common carbonaceous plant fragments, some randomiy oriented; lower contact gradational--- 2.6

Siltstone, medium-gray, chunky - to poor platy-weathering, very thin to thin-bedded, sandy in lioper part; some carbonaceous

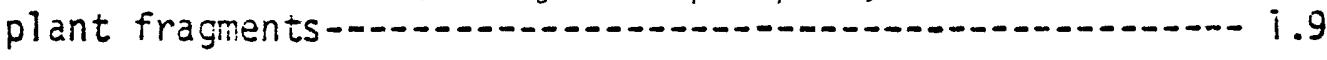

Shale, medium-dark- to dark-gray, carbonaceous; common carbonacecus piant fragrents; includes abundant bony coal stringers in upper $0.1 \mathrm{ft.}$

*Palynological sample 
Coal, dull, blocky; lower contact sharp-1... 0.2

Siltstone, medium-gray, slabby-weathering, ciayey in lower part becoming sandy in upper part; common carbonaceous plant fragments, mostly randomily oriented; includes $0.3-$ $\mathrm{ft}$. bed of medium-gray fairly friable very fine grained silty sandstone at top-a.-. 5.5

Coal, bony-1

Sandstone and interbedded siltstone; sandstone, mediumgray, platy-weathering, very thin bedded, part?y laminated, friabie, very fine grained, subangular, very silty; siltstone, redium-gray, obscurely thin-bedsed, clayey; abundant carbonaceous plant fraginents; upper $1 \mathrm{ft}$. of unit is chiefly silts tone; unit includes two $0.1-\mathrm{ft}$. beds of dark-gray very caroonaceous silitstone near middle and near base; lower contact sharp-..........-.- 2.2

Shale, medium-gray, obscurely bedded, probably platy-bedded, clayey; common carbonaceous plant fragments; includes

few thin siltstone beds; iower contact gradational-......- 2.1

Sands tone, medium-gray, slabby-weathering, platy- to very thin bedded, Dartly laminated, fairly friable, very fine grained, subangular, silty, clayey in upper 0.5

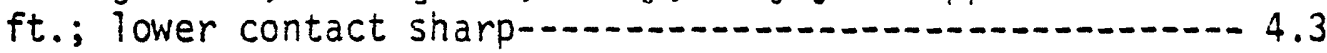

Siltstone, mediun-gray, obscurely bedded, slightly friable; locally abundant sriall carbonaceous plant fragments; lower contact sharp-_- 1.7

Sandstone, medilim-gray, platy - to very thin bedded, partly laminated, fairiy friable, very fine grained, subangular, silty; includes abundant micaceous carbonaceous laminations in $0.3-\mathrm{ft}$. zone $0.3 \mathrm{ft}$. below top; lower contact sharp-1..- 2.8

Silts tone, medium-gray, chunky-weathering(?), obscurely bedded, clavey; locally abundant carbonaceous plant

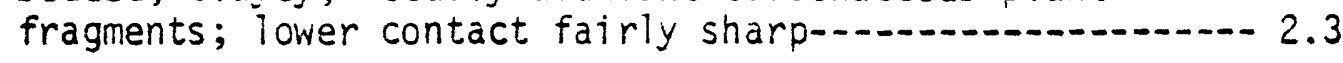

Sands tone, medium-gray, platy-weathering, laminated to very thin bedded, friable in few thin beds in upper half, very fine grained, subangular, mostly clayey, very silty; includes some interbeds of medium-gray siltstone -- princioally in lower $1 \mathrm{ft}$.; lower contact gradational-a-_. 3.8 
Siltstone, medium-gray, poor platy-bedied; abundant small carbonaceous plant fragments; some large thin carbonaceous plant fragments; few coal films; several thin interbeds of medium-gray concioidally fracturing clayey shale with many cartonaceous plant fragmants;

lower contact gradationai-_........... 1.6

Shale, medium-gray, poor piaty-bedded; abundant small carbonaceous plant fragments-1... 0.5

Coal, blocky; inciudes $0.15-\mathrm{ft}$. bed $0.1 \mathrm{ft}$. below top of medium-dark-gray to brownish-gray shale with many

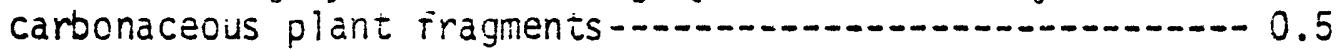

Siltstone, medium-gray to brownish-gray, obscurely bedded; many small carbonaceous plant fragments; lower contact

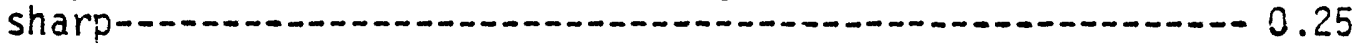

Sandstone and interbedded silistone; sands tone, medium-gray, poor platy-weathering, very thin to thin-bedded, friabie in bottom $1 \mathrm{ft}$, very fine to fine-grained in basal $1 \mathrm{ft}$. becoming very fine grained above, subangular, very silty, clayey above basal $1 \mathrm{ft}$.; some carbonaceous plant fragments - mostiy in beds $0.5 \mathrm{ft}$. to $1 \mathrm{ft}$. thick; siltstone, medium-gray, obscurely very thin to thinbedded, clayey; includes feiv smail leaf impressions in upper part; lower contact snarp-......................... 13.3

Siltstone, medium-gray, hackly- to poor platy-weathering, obscureily very thin to thin-bedded, sandy; locally abundant carbonaceous plant fragments; many large poorly oriented coalified wood fragments 2.5-3.5 ft. above base; includes many beds up to $1 \mathrm{ft}$. thick of medium-gray very thin bedced very fine grained sand-

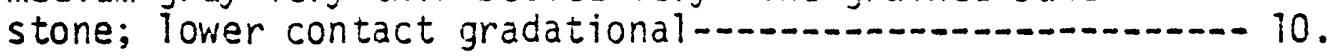

Shale, mediuin-gray to medium-dark-gray, poor fissile to platy-bedded, silty, clayey; abundant carbonaceolis

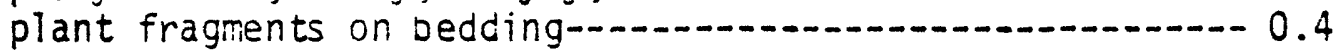

Coal ( $5 P-20-2$ shale partings)*, platy - to blockyweathering; many large coalified wood framents; includes $0.6-\mathrm{ft}$. parting $0.4 \mathrm{ft}$. beiow top of medium-gray very silty shale with abundant plant fragments; $0.5-\mathrm{ft}$. parting $2.3 \mathrm{ft}$. below top of medium-dark-gray very silty shale with abundant plant fragments-_................... 5. 
Siltstone, medium-gray, partly iron-stained, hackly- to platyweathering, very thin to obscurely bedded, clayey to very clayey; locaily abundant plant fragments; includes 2-ft. bed $5 \mathrm{ft}$. below top of medium-gray platy-weathering very thin bedded to laminated silty sandstone with few leaf

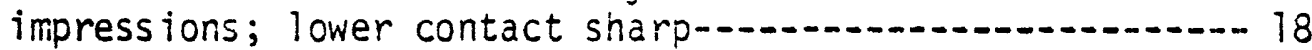

Sandstone, medium-gray, platy-weathering, very thin bedded, partiy friable, very fine grained, subangular to subrounded, silty; includes $0.1-\mathrm{ft}$. siltstone bed $0.2 \mathrm{ft}$.

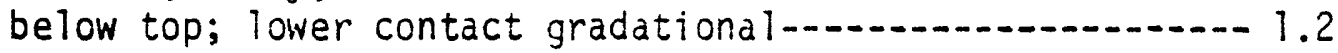

Silts tone, medium-gray, hackly-weathering, obscureiy bedded; includes 1-ft. bed at base of medium-gray platy-weathering very thin bedded clayey to very clayey shale with abundant carbonaceous piant fragments-.................-. 4.2

Coal, platy-weathering, deeply weathered, bony; includes many very tnin siltstone partings $0.2-0.5 \mathrm{ft}$. below top; $0.2-\mathrm{ft}$. bed $0.5 \mathrm{ft}$. below top of brownish-gray deeply weathered poor piaty-becded to fissile shale-.....- 0.9

Siltstone, medium-dark-gray, clayey; abundant plant fragments and finely disseminated carbonaceous material; includes carbonaceous lenses; lower contact gradational-..-- 0.4

Siltstone, medium-gray, iron-stained in upper half, hacklyweathering, obscurely bedded, clayey, sandy in upper 2 ft; abundant plant remains; lower contact gradational-...-. 4.3

Shale, medium-gray, platy-weathering, obscurely fissile, silty, very clayey; abundant small plant fragments; some large coalified wood fragrents in upper part; lower contact gradational-2.-1 2.5

Shale, dark-gray, fissile- to platy-weathering, clayey, carbonaceous; abundant plant fragments-................... 0.3

Siltstone, medium-gray, locally hard and calcareous cemented, very clayey; abundant plant fragments

Shale, dark-gray, platy-weathering, clayey, carbonaceous; abundant plant fragments-...... 0.1

Coal, deeply weathered, fissile-weathering in lower $0.6 \mathrm{ft}$.; mostly coalified wood remains; bony in upper $0.4 \mathrm{ft}$.; includes many thin interbeds of dark-gray carbonaceous

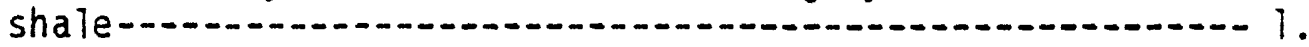


Siltstone and interbedded sandstone; siltstone, mediumgray, platy-weathering, very thin bedded, clayey, sandy; sands tone, medium-gray, platy-weathering, very thin bedded, mostly friable, very fine grained, subrounded to subangular, very siity; basal $1.5 \mathrm{ft}$. of unit is medium-grained subrounded to subangular sandstone with large coal ified wood fragments; silts tone dominates in lower half of unit and sandstone dominates in upper half of unit; unit includes $1-f t$. bed at top of medium-gray shale $(5 \mathrm{SP}-14)^{*}$ with common plant fragments; lower contact fairly sharp-....................- 20

Sandstone and interbedded siltstone; sands tone, rediumgray, platy-weathering, very tnin bedded to laminated, very fine grained, sliangular, very silty; forms beds mostly $0.5 \mathrm{ft}$. thick; includes carbcnaceous laminations; siltstone, mediumi-gray, partiy iron-stained very thin bedded to laminated, vartiy sanciy; forms beds mostiy $0.5 \mathrm{ft}$. thick; unit inciudes $1.5-\mathrm{ft}$. silts tone bed at base; 1.2-ft. bed at top of medium-gray very thin bedded to laminated siltstone with abundant carbonaceous plant fragments; orownish tint in lower $0.2 \mathrm{ft}$.; iower contact sharp-a- 8.7

Shale, dark-gray to black, platy-weathering, carbonaceous; abundant plant fragments, coai films, and partings-...-.-- 0.2

Coal, platy-weathering-1.

Siltstone, medium-gray, partly iron-stained, probably very thin bedded, clayey; abundant carbonaceous plant fragments; includes at base abundant large coalified wood fragments in 0.4-ft. bed of dark-gray to black carbonaceous siltstone with many coal films and partings-...-.- 1.3

Coal, bony; includes very thin partings of medium-dark-gray carbonaceous siltstone--_-_- 0.4

Siltstone, medium-gray, hackly-weathering, obscurely bedded, probably thin-bedded, Dartly sandy; common small plant fragments; includes $4-\mathrm{ft}$. bed $2 \mathrm{ft}$. above base of platyweathering very thin bedded cross-bedded subangular very fine grained very silty sandstone that becomes slabby-weathering and friable in iower $1 \mathrm{ft}$.; lower

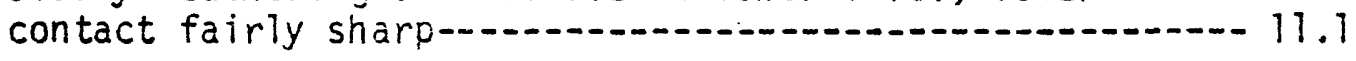


Sandstone, medium-gray, locally iron-stained, slabby-weathering, friable, fine- to medium-grained, fine-grained in upper $1 \mathrm{ft}$, subrounded to subangular; lower contact sharp and possible disconformi ty-_.-. 6.6

Coal, blocky; lower contact sharp-a...- 0.4

Siltstone, medium-gray, hackly-weathering, obscurely bedded, probabiy thin-bedded, partly very sandy, ciayey; includes at base $0.5-\mathrm{ft}$. bed of medium-gray shale $(5 P-9) *$, with abundant plant fragments that grade into overlying siltstone; $2.8 \mathrm{ft}$. bed $0.2 \mathrm{ft}$. beiow top of medium-gray slabby-weathering very thin bedded partly friable very fine grained sandstone; $0.2-f t$. bed at top of mediumdark-gray carbonaceous siltstone with many plant fragments; lower contact sharp-1...- 11.8

Shale, dark-gray to black, platy-weathering, carbonacecus; white scattersd very fine crystals; abundant carbonaceous

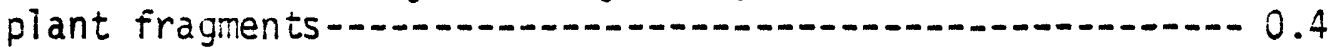

Coal, platy-weathering, bony; includes interbedded dark-gray to black carbonaceous shale; lower contact sharp--.-.-.-.-- 0.4

Siltstone, medium-gray, hackly-weathering(?), obscurely bedded, probably thin-bedded, clayey, partly sandy; locally abundant carbonaceous plant fragments; large coalified wood fragments oriented perpendicular to bedding near top of unit; includes interbeds up to 0.5 ft. thick of medium-gray platy-weathering very thin bedded to laminated very fine grained sandstone in upper $3 \mathrm{ft.} . \ldots$

Coal and interbedded shale; coal, bony; large coalified wood remains; shale, dark-gray to black, carbonaceous-...- 0.4

Sands tone, medium-gray, slabby-weathering, obscurely bedded, fairly friable, very fine grained, subrounded to subangular, very silty and clayey in upper $1.5 \mathrm{ft} .$. ; some carbonaceous plant fragments; large coalified wood re-

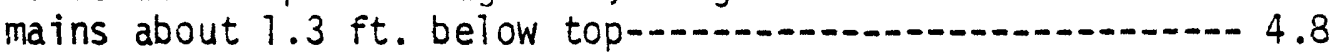

Siltstone and interbedded sandstone; siltstone, medium-gray, poor platy - to thin-bedded, sandy; many carbonaceous plant fragments; sandstone, medium-gray, obscurely bedded, very fine grained, subrounded to subangular; lower contact gradational-_. 15.8 
Sandstone, medium-gray, partiy iron-stained, obscurely bedded, mostly friable, becoming less friable toward top, very fine grained, subrounded, very clayey in upper haif and grades to sandy siitstone in part_............................. 10.3

Siltstone, medium-gray, poor platy - to thin-bedded, clayey; many carbonaceous plant iragments; includes numerous thin beds of very fine grained sandstone; iower contact gradationa 1--

Sandstone, medium-gray, slightiy iron-stained, slabby-weathering, very thin bedded, partly laminatad, very fine grained, subangular, very silty; lower contact fairly sharp-..-...-.

Shale, medium- to medium-dark-gray, partly iron-stained, obscureiy bedded, silty; many small carbonaceous plant fragments; few large carbonaceous olant fragments in ueper i ft.; few large coalified wood fragments at 0.3-0.5 ft. above base; iower contact sharp-....--

Coal, Fietcner ted, partly platy-weathering, blocky; lower contact sharp-.--

Sandstore, medium-gray, slabby-weathering, obscurely bedded, friable in small part, very fine grained, subanguiar, silty; scattered carbonaceous plant fragments; inciudes $2-\mathrm{ft}$. bed $1 \mathrm{ft}$. below top of medium-gray obscurely bedded sandy very clayey siltstone with many carbo-

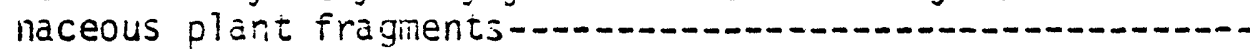

Siltstone, medium-gray, locally ledge-forming, obscurely bedded, nard, limy, sandy; abundant smali carbonaceous

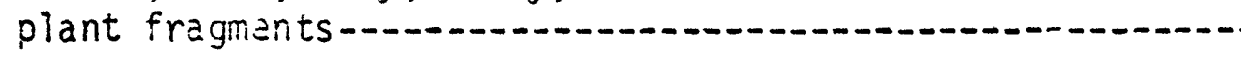

Siltstone, medium-gray, poor very thin bedded, clayey to very sandy; common carbonaceous plant fraginents; includes few thin interbeds of medium-gray very fire grained subangular very silty sandstone in upper $4 \mathrm{ft}$.; lower contact sharp--...-

Snale, dark-gray to black, platy-bedded, silty, carbonaceous; includes bony coal stringers

Sandstone, redium-gray, partly iron-stained, siabby-weathering, very thin to thin-bedded, platy- to thin-bedded in upper $5 \mathrm{ft}$., cross-bedded, mostly friable, very fine to fine-grained, subanguiar, silty to very silty, very clayey in upper $5 \mathrm{ft}$.; incluces several thin interbeas of sarcy

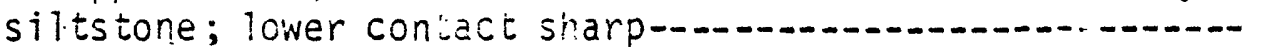


Shale, medium- to medium-dark-gray, platy-weathering, platybedded, silty, caroonaceous; many carbonaceous piant

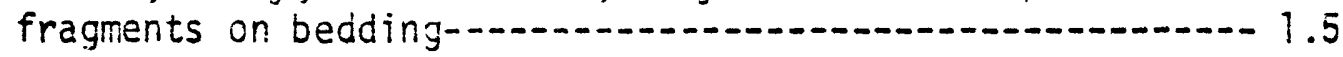

Coal, platy-weathering; mostly large coalified wood remains; includes 0.?-ft. Parting $0.4 \mathrm{ft}$. above base of mediumgray shale with many caroonac=ous plant fragments; lower contact sharp and rolling-.......... 3.7

Siltstone, mediun-gray, slabby-weathering, obscurely thinbedded, clayey; many small carbonacecus plant fragments; some large piant remains oriented perpendicular to bedding at top; inc?udes mediur-gray hara dense limy siltstone concretions up to $0.9 \mathrm{ft}$. $\times 5 \mathrm{ft}$. at top; lower contact not examined-1.-... 
Measured section 6

Location: Gully and hillside exposures at forks of Swift Creek in NW 1/4 SW 1/4 NE 1/4 sec. 23, T. 4 S., R., 11 W., Seldovia $0-3$ quadrangle. This location is approximately the same as locaity 158 of Barnes and Cobb (1959, p1. 18).

Feet

Pleistocene deposits, slumpy-1.--about 95.

Unconformity; covered by slope wash

Tertiary rocks-Kenai Group, Sterling Formation

Siltstone, medium-gray, partly ircn-stained, cbscurely bedded, clayey; feiv carbonaceous plant fragments;

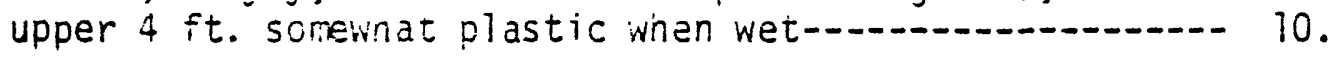

Sandstone, medium-gray, obscurely bedded, friable, very

fine to fine-grained, subangular, silty, clayey;

scattered coaly wood fragments; includes very thin

beds of medium-gray coscurely bedded clayey siltstone

in upper $0.4 \mathrm{ft.}$.

Siltstone, medium-gray, partly lightly iron-stained, obscureiy becded, clayey, shaly in upper $5 \mathrm{ft}$.; few carbonaceous piant fragments; inciudes $0.3-\mathrm{ft}$. bed of brownish-gray carbonaceous siltstone at $4 \mathrm{ft}$. above base; lower contact sharp-a.

Siltstone and coal; siltstone, brownish-gray, poor platybedded, clayey, carbonaceous; forms lower two-thirds of unit; coal, impure(?); lower contact sharp-.........-.

Siltstone and interbedded sandstone; siltstone, medium-gray, partly iron-stained, chunky- to poor platy-weathering, obscurely platy - to very thin bedded, clayey; few carbonaceous plant fragments; sands tone, medium-gray, partly iron-stained, cbscurely very thin bedded, partiy

friable, very fine grained, subangular to subrounded; occurs in middle and lower part of unit in beds up to $0.5 \mathrm{ft}$. thick; unit includes some thin beds of mediumgray shale with common plant fragments in upper 1.5 $\mathrm{ft}$.; clayey ironstore nodules $0.1-0.2 \mathrm{ft}$. thick about $3 \mathrm{ft}$. below top; lower contact fairly sharp-.................. 
Sandstone, medium-dark-bluish-gray, partly iron-stained, slabby-weatnering, mostly iriable, fine- to mediumgrained, scattered coarse grains in basal $0.7 \mathrm{ft}$. becoming dominately fine-grained above, subanguiar to subrounded; numercus rounded shale flakes; lower contact sharp and possibly disconformable.................. 3.3

Shale $(6 P-73)^{*}$, medium-gray, obscurety bedded; many carbonaceous plant fragments; lower contact sharp-......- 0.2

Shale, brownish-gray to dark-gray, platy-bedded, hard,

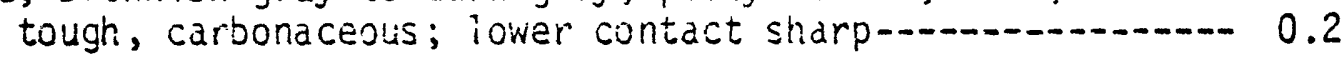

Siltstone, redium-gray, poor platy-weathering, obscuraly platy - to very thin bedded, shaly in lower part, clayey, partiy finely sandy; few small carbonaceous plant fragrients and large coalified wood fragments near oase; includes some interbedded very fine grained sancs tone about 5-6 ft. above base; bed less than $0.1 \mathrm{ft}$. thick of medium-dark-gray pooriy bedded shale with abundant piant fragments at top-.......-

Coal, weathered, largeiy impure(?)

Sandstone, medium-gray, partiy iron-stained, slabby-weathering, poor platy-oecded in upper half, very friable in lower haif, fine-grained in lower half becoming very fine grained to fine-grained and clayey in upper nalf, subangular to subrounced; lower contact sharp-.............

Siltstone, medium-gray, poor platy - to chunky-weathering, obscurely bedded, clayey, snaly in basal $0.5 \mathrm{ft}$. and upper $0.3 \mathrm{ft}$, sandy in middle part; comon plant

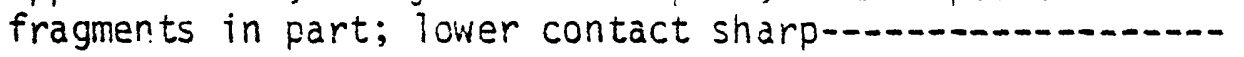

Shale, medium- to medium-dark-gray, obscurely bedded; abundant carbonaceous plant fragments; includes few very thin beds of dark-gray to black impure coal or carbonaceous shale in lower half; at top 0.25-ft. bed of brownish-gray to dark-gray platy-bedded carbonaceous shale with abundant piant fragments on bedding-........... 1.8

Coal, blocky; includes medium-brown friable sandy siltstone parting $0.1 \mathrm{ft}$. thick at $0.1 \mathrm{ft}$.below top; much woody material in loper $0.1 \mathrm{ft}$; irregular short stumps

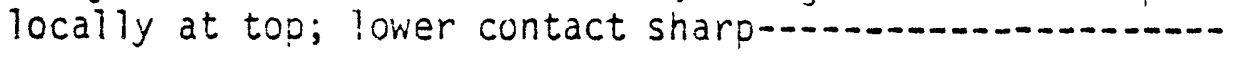


Shale $(6 P-69) *$, medium-gray, medium-iight-gray-weathering, obscurely bedded, poor platy-bedded in upper $0.5 \mathrm{ft}$. , hard; abundant plant fragments; abundant si ickensides about $0.5 \mathrm{ft}$. below top; lower contact gradationai-...-.-- 1.8

Siltstone, medium-gray, medium-dark-gray in lower $1 \mathrm{ft}$., pcor platy-weathering(?), poor platy-bedded, clayey; abundant plant fragments in lower 1 ft.; few large coalified wood remains and localiy aburdant carbonaceous root remains in upper $2 \mathrm{ft}$; lower contact sharp-a.-... 3

Sandstone, medium-gray, partly iron-stained, slabby-weathering, mostiy obscurely bedced, partiy platy-bedded, friable, very fine grained, subangular; inciudes 1-ft. bed of medium-gray laminated partly friabie siltstone at base; 1-ft. bed, $8 \mathrm{ft}$. above base, of Tedium-gray obscurely bedied clayey siltstone with comon plant fragments; 1-ft. bed of mediurn-gray cnunky - to poor platy-weathering clayey siltstore at $18 \mathrm{ft}$. above base; 1.5-ft. bed of similar silitstone at $27 \mathrm{ft}$.

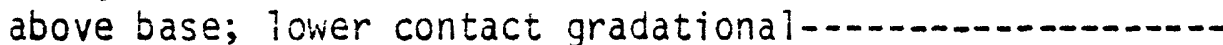

Siltstone, medium-gray, partly iron-stained, chunky- to poor platy-weathering, obscurely bedded, clayey; scattered carbonaceous plant fragments; lower contact gradational-

Sandstone and interlaminated siltstone; sanastone, mediumgray, platy-weathering, uniformly laminated, very fine grained, subangular, very silty, clayey; siltstone,

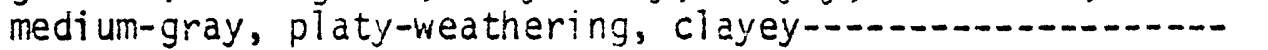

Siltstone, medium-gray, partly iron-stained, chunky-weathering, obscurely bedded, clayey; scattered piant fragments; includes $1-\mathrm{ft}$. bed, $0.5 \mathrm{ft}$. above base, of friable very fine graired sandstone; $0.5-\mathrm{ft}$. bed in middie of medium-gray obscurely bedded shaie; lower contact

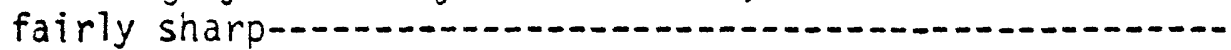

Sands tone, medium-gray, partly ircn-stained, slabby-weathering, obscurely to partly platy-bedded, friable, very fine grained, subangular, sil cy; includes interbeds of medium-gray partiy friable clayey siltstone; lower

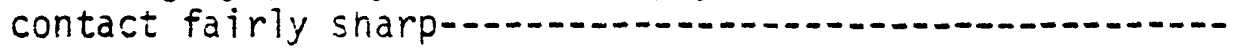

Siltstone, medium-gray, chunky-weathering, obscurely bedded, partiy poor platy-bedded, clayey; common plant fragments; lower contact gradational 
Sands tone, medium-gray, partly iron-stained, slabby-weathering, mostly ooscurely bedded, scme platy-to very thin bedded, friable, very fine to fine-grained, subanguiar; becomes very fine grained, clayey, and less friable in upper $3 \mathrm{ft}$. ; lower contact gradational-.....................

Siltstone, medium-gray, partly iron-stained, platy-weathering, laminated, finely sardy, clayey; may include ironstone nodules near top; lower contact gradational-............-. 2.

Shale, medium- to medium-dark-gray, poor piaty-weathering in upper $0.5 \mathrm{ft}$. , coscurely bedcied, locally fissile, poor piaty-bedded in loper $0.5 \mathrm{ft}$., very silty in upper 0.5 ft.; abundant carbonaceous plant fragments; includes $0.2-\mathrm{ft}$. bed, $2.5 \mathrm{ft}$. above base, of shaie with scattered to abundant white medium-sand-size pyroclastic grains

Coal, upper $0.5 \mathrm{ft}$. deecly weathered bone coal; includes $0.5-\mathrm{ft}$. parting, $0.5 \mathrm{ft}$. above base, of medium-gray hard shale with abundant piant fragments; $0.8-\mathrm{ft}$. parting, $1.9 \mathrm{ft}$. above Dase, of medium-gray clayey siltstone with abundant large coalified wood re-

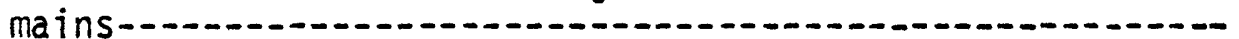

Siltstone, medium-gray, partly iron-stained, slabbyweathering, obscurely platy-bedded, clayey; felw carbonaceous plant fragments; includes at top 2-ft. bed of medium-gray slabby - to platy-weathering platy-bedded very fine grained subangular sands tone; lower contact gradational-....-..-.-.

Sandstone, medium-gray, partly iron-stained, platy-weathering, platy - to very thin bedded, partly friable, very fine grained, subrounded, silty, very clayey in part; includes 1-ft. bed, about $0.3 \mathrm{ft}$ above base, of finegrained friable sandstone with few large coalified wood fragments and few lenses and thin beds of interTaminated carbonaceous material and sandstone; $1-\mathrm{ft}$. bed, $6 \mathrm{ft}$. above base, of medium-gray platy-weathering platy-bedded siltstore; 5 -ft. bed, $7 \mathrm{ft}$. above base, of fine-grained friable sardstone; lower contact gradational

Siltstone, medium-grav, partly lightly iron-stained, platyweathering in unoer half and chinky-weathering in lower half, platy - to very thin bedded, clavey; scattered carbonaceous plant fragments; lower contact gradational-- 
Shale, medium-gray, obscurely bedded, silty; abundant

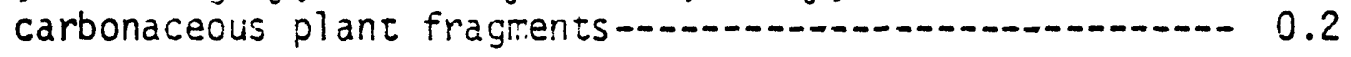

Coal, bone-1 0.2

Siltstone, brownish-gray to medium-gray, poor fissile to platy-bedced, clayej; abundant carbonaceous wood fragments; some large coalified wood remains oriented

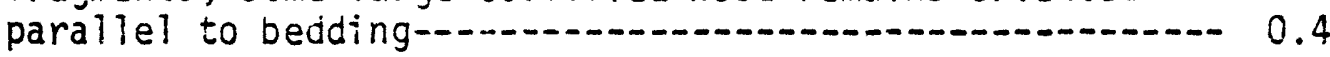

Shale (6P-57)* medium-gray, obscurely bedded; many carto-

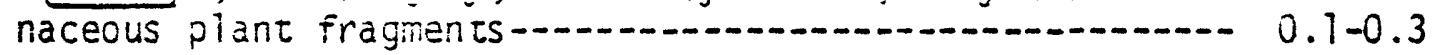

Coal, lower $1.2 \mathrm{ft}$. poor tiocky; upper $0.3 \mathrm{ft}$. probably very

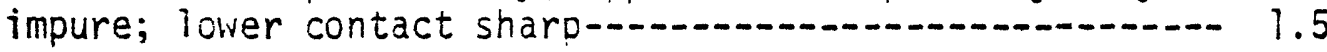

Siltstone, medium-gray, poor platy-weathering, partly poor platy - to very thin cedded, clayey, micaceols; locally common cartonaceous plant fragments; upeer nalf includes few beds, $0.5 \mathrm{ft}$. thick, of medium-gray shale with many carbonaceous plant fragments; !arge slickensides about $1 \mathrm{ft}$. above oase; lower contact gradationa

Sandstone and interbedded siltstone; sandstone, mediumgray, obscurely bedded. very fine grained, subangular, very clayey; some carooriaceous plant fragments; siltstone, medium-gray, obscurely bedded, clayey; common carbonaceous plant fragments; unit weathers slabby to poor platy; lower contact fairly sharp-................. 4.5

Sandstone, medium-gray, mostly iron-stained, partly laminated to piaty-bedded, partly friable, very fine grained, subangular, micaceous, mostly clayey; some carbonaceous

plant fragments-.-...- 1.

Siltstone, medium-gray, partly iron-stained, obscurely

bedded, clayey; many carounaceous plant fragments-......-- 0.9

Coal

Siltstone, brcwnish-gray to dark-gray, platy-bedded, clayey,

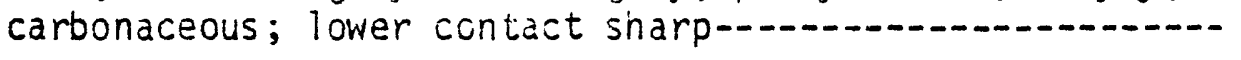


Sandstone and interbedded siltstone; sandstone, medium-gray, partly iron-stained, obscureiy very thin bedded, partiy friable, very fine grained, subangular, silty, very clayey; local caroonaceous plant fragments randomly oriented in part; includes 1.4-ft. bed of friatle sandstone at $1 \mathrm{ft}$. below top; siltstone, mediuni-gray, obscurely bedued, largely sandy, ciayey; some carbonaceous plant fragments rancomly oriented in part; unit includes at top few ironstone nodules, $0.25 \mathrm{ft}$. thick, with abundant srial 7 carbonaceous p! ant fragments; unit weathers slabby; lo:ver contact sharp-.......-...-.- 20.

Siltstone, brownish-gray to dark-gray, poor fissile to platybedded, clayey, carbonaceous; abundant carbonacecus plant fragments on bedding; lower contact fairly sharp--- 0.5

Siltstone, medium-gray, obscurely bedded, clayey; some carbonaceolis piant fragments; inciudes interbeds of very fine grained very clayey sands tone in upper half; lower contact gradational-a...-

Sandstone, mediun-gray, slabby-weathering, obscureiy bedded, very fine grained, subangular to subrounded, very clayey; few carbonacecus plant fragments; lower concact sharp-.--

Sands tone, medium-gray, slabby-weathering, obscurely bedded, friable, medium- to coarse-grained in basal part becoming fine-grained in upper part, subrounded, clayey, micaceous in lower part; basal part includes few smaii medium-gray shale flakes up to $0.05 \mathrm{ft}$, thick-...........-.

Siltstone, medium-gray, poor slabby-weathering, obscurely bedded, clayey; common carbonaceous plant fractinents; few large randomly oriented coal ified wood fragments in upper $1 \mathrm{ft}$. ; few coal stringers; includes at top $0.6-\mathrm{ft}$. bed of brownish-gray poorly bedded carbonaceolis

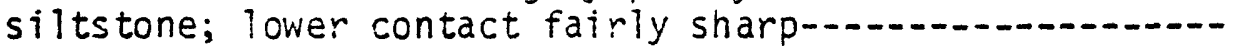

Sandstone, mediurn-gray, partly iron-stained, obscurely bedded in lover part becoming very th in beaded and cross-bedded in upper $3 \mathrm{ft}$., friable to pooriy friable in upper half, very fine to fine-grained, subangular; very clayey in upper $3 \mathrm{ft}$.; common rancomly oriented plant fragrents in upper $3 \mathrm{ft}$.; few large coalified wood remains normal to bedding in upper $1 \mathrm{ft}$.; includes few thin beds of medium-gray obscurely bedded very clayey siltstone in upper $3 \mathrm{ft}$; i iower contact sharp-.......-.-. 
Siltstone, medium-gray, partly iron-stained, poor slabbyweathering, obscureiy bedded, clayey; abundant rancomly oriented carbonaceous plant fragrents in part; includes few thin beds of medium-gray very iine grained sandstone in upper $1.4 \mathrm{ft}$.; lower contact sharp and sorre-

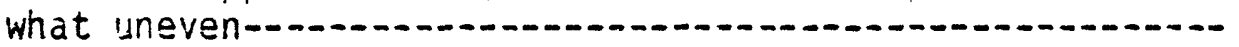

Sandstone, medium-gray, mostly iron-stained, slabby-weathering, obscurely bedded, friabie, very fine to finegrained, subangular to subrounded; lower contact fairly sharp-.-.-..-

Siltstone, medium-gray, chunky-weathering, obscurely becded, soft; abundant carboriaceous piant fragrents in bas ii part and scattered in upper part; iower contact snarp---- 0.4

Siltstone, brownish-gray, fissile, carbcnaceous; lower contact fairly snarp-a. 0.2

Sandstone, medium-gray, strongly iron-stained in lower part, slabby-weathering, obscureiy bedded in lower part, platy - to very thin sedded in upper nalf, friabie, fine- to medium-grained in lower part becoming very fine grained in upper half, subangular to subrounded, slightly silty; scattered large coalified wood re-

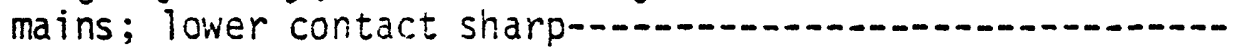

Sandstore and interbedded siltstone; sandstone, mediumgray, partly iron-s sained, platy - to very thin oedded, partiy friabie, very fine grained, subangular, silty; conmon carbonaceous laminations; silts tone, mediumgray, partly lightly iron-stained, ooor platy-weathering, platy - to very thin bedded, sandy; locally abundant carbonaceous plant fragments; lower contact fairly sharp-

Shale, medium-dark-gray, fissile to platy-bedded, carbonaceous; abundant carbonaceous plant fragments-..........- 0.6

Siltstone and interbedded coal; siltstone, brownish-gray, fissile to platy-bedded, clayey; adundant plant remains; forms beds up to $0.3 \mathrm{ft}$. tnick: coal, most?: coalified wood remains; forms o beds up to $0.4 \mathrm{ft}$.

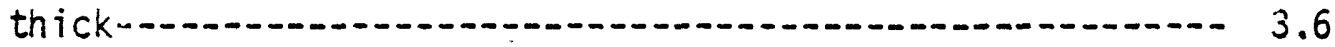

Coal, abundant coal ified wood remains; weathered-..............- 1. 
Sandstone, medium-gray, light-gray-weathering, iron-stained, poor platy-weathering, platy(?)-bedded, partly friable, very fine to fine-grained, subangular to subrounded;

few large coalified plant remains mcstly oriented parallel to bedding; includes few coal lenses and stringers in upper $0.3 \mathrm{ft}$; lower contact gradational-...- 1.5

Siltstone, miedium-gray, slabby- to chunkv-weathering, obscurely bedded, clayey; lower contact gradational-.......- 1.

Shale $(6 P-46) *$, medium-gray, obscurely bedded; common to locally abundant piant fragments; numerous large coalified wood remains oriented mostiy paraliel to bedding; inciludes irreguiar ironstone nodules up to $0.2 \mathrm{ft}$. thick at $0.3 \mathrm{ft}$. above base; common slickensides-1.-_-_.

Coal, duil, platy-weathering; lower contact sharp-........-..-- 0.5

Sandstone, medium-gray, iron-stained in icwer part, $o b-$ scureiy beaded, iriatie, very fine to fine-grained becoming very fine grained in upper $0.5 \mathrm{ft}$., subangular; clayey in upper $0.5 \mathrm{ft}$.; includes common randomly oriented piant fragments in upper $0.5 \mathrm{ft} . . . . . .-3.5$

Siltstone, redium-gray, partly iron-stained, poor platy- to chunky-weathering, partiy platy-bedded, partly clayey; locally abundant smaii carbonacecus plant fragments; includes beds, up to $1.5 \mathrm{ft}$. tnick, of medium-gray platy-beddea partly friable very fine to fine-grained sandstone; 0.3-ft. bed of medium-dark-gray carbonacesus siltstore overlain by $0.2-\mathrm{ft}$. bed of bone coal at top;

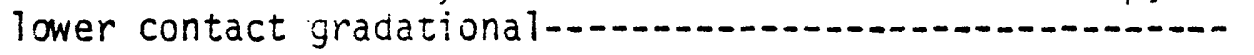

Sandstone, medium-gray, partly iron-stained, olaty-weathering, laminated to very thin bedded, partiy friabie, very fine to fine-grained, subangular, partly silty, partly clayey-1.-.

Shale, brownish-gray, poor fissile to platy-bedded, carbo-

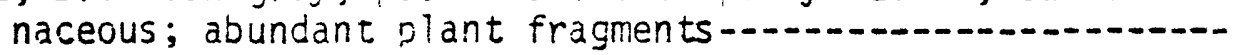

Coal, Bed $T($ ?), platy-weathering; includes 3 brownish-gray platy-bedded to fissile carbonaceous shale partings $(0.2 \mathrm{ft}$. thick $0.4 \mathrm{ft}$. below top, $0.1 \mathrm{ft}$. thick 0.8 $\mathrm{ft}$. below top, $0.3 \mathrm{ft}$. thick $1.2 \mathrm{ft}$. beicw top); much

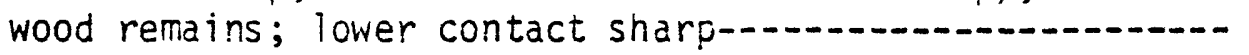


Siltstone, medilum-gray, chunky-weatnering, obscurely bedded, partly very thin bedded, hard, very clayey; iocally abundant carbonacecus plant fragments; few randomiy oriented large coalified wood iragments about $2 \mathrm{ft}$. below top; inciudes at top 0.j-ft. bed of medium-orownishgray very thin bedded claysy siltstone with abundant carbonaceous piant fragments; iower contact gradational-a.-.- 6

Sandstone, medium-gray, platy-weathering, laminated to platybedded, partiy friable, very fine grained, subangular, partly very clayey; lower contact sharp-.......................

Siltstone and shale; silts tone, brownish-gray to medilimgray, chunky - to poor platy-weathering, platy-bedded to fissile; iocally abundant caroonaceous plant fragments; forms upper half of unit; snale $(6 P-41)^{*}$, medium-grav, obscurely bedded; common plant iragments; includes 0.0z-ft. black carbonaceolis shale bed at base;

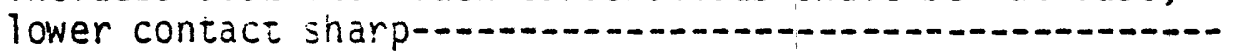

Sandstone and interbedded siltstore; sandstone, medium-gray, platy-weathering, platy-bedded to laminated, very fine grained, subangular; includes few very thin beds of friable very fine grained sands tone; siltstone, mediumgray, obscurely bedded, clayey; common carbonaceous plant fragments; occurs in 2 beds $(0.5-\mathrm{ft}$. bed in middle of unit and $1-\mathrm{ft}$. bed near top); lower contact

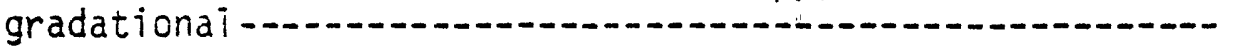

Sands tone, medium-1ight-gray, s labby-weathering, poor cliff-forming, piaty- to very thin bedded, crossbedded (sets about $1.5 \mathrm{ft}$. thick), friable, iess friable in upper $2 \mathrm{ft}$., fine-grained becoming very fine grained in upeer $2 \mathrm{ft}$., subangular to subrounded; includes few thin iron-cemented carbonaceous beds and lenses up to $0.1 \mathrm{ft}$. thick; lower contact sharp-......-.- 10.8

Sandstone, medium-gray, mostly iron-stained, platy-weathering, evenly placy-bedded; abundant carbonaceous laminae-......- 
Sandstone, nedium-light-gray, partly iron-stained, slabbyweathering, sinooth steep sicpe-forming, piaty - to very thin bedided, even and platy-bedded in upper $2 \mathrm{ft}$. , cross-bedded, friable, inne- to medium-grained in basai part becoining dominately fine-grained $5 \mathrm{ft}$. atove base, very fine to fine-grained in upper $2 \mathrm{ft}$., subangular to subrounded, silty; contorted bedding bezween 4 and $10 \mathrm{ft}$. below top; long narrow coalified piant fragments in basal $0.2 \mathrm{ft}$.; includes scattered ironstones; some very thin iron-cemented carbonaceous becs; abundant ironstones up to $0.2 \mathrm{ft}$. thick at base; lower contact sharp-...-

Siltstone, medium-gray, slabby- to poor platy-iveathering, poor platy - to very th in bedded, clayey; carbonaceous plant fragments locaily abundant; graces to mostly medium-gray laminated very fine grained clayey sand-

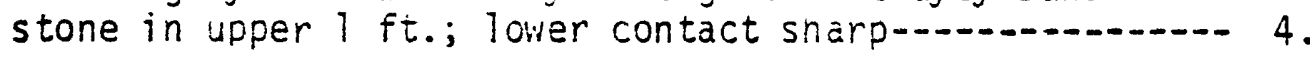

Sands tone, medium-gray, iron-stained, slabby-weathering, obscureiy beaded, friabie, very fine grained, sub-

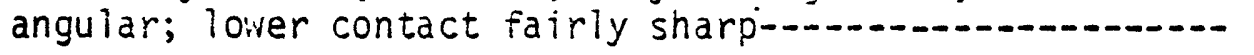

Silts tone and interbedded sandstone; siltstone, medium-gray, platy - to very thin bedded, clayey, Dartly sandy; common carbonaceous piant fragments; sandstone, mediumgray, slabby-weathering, obscurely very th in bedded, partly friable, very fine grained, subangular, very clayey; includes ironstone nodules up to $0.2 \mathrm{ft}$. thick at about 1 and $2.5 \mathrm{ft}$. above base; $0.3-\mathrm{ft}$. bed of mediumgray friable very fine grained sandstone near middle;

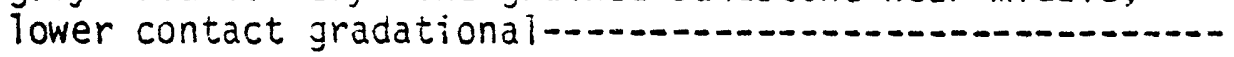

Sands tone, medium-gray, partly iron-stained, slabby-weathering, odscureily very thin bedaed, friable, very fine grained, subangular, very ciayey; lower contact gradational

Siltstone, medium-gray, obscurely bedded, ciayey, partly sandy; few carbonaceous plant fragments; includes at base 0.3-ft. bed of medium-gray platy- to very thin bedded shale with aburdant small caroonaceous plant fragments -

Coal, dark-brownish-gray to black, platy-weathering; abundant large coalified wood fragments; lower contact sharp--..-...- 
Silts tone, medium-gray, poor platy(?)-weathering, obscurely bedded, clayey; abundant partly randomiy oriented

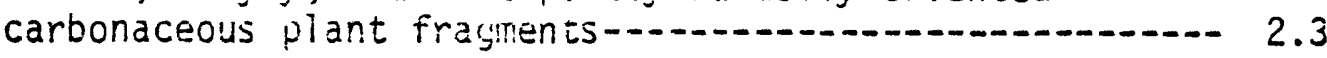

Coal, very inpure, bony-1.- 0.3

Shale, medium-gray, poor platy-bedded; abundant carbonaceous plant fragments--.- 0.3

Coal, very impure, bony-1..- 0.3

Shale, medium-gray, poor platy-bedded; aburidant carbo-

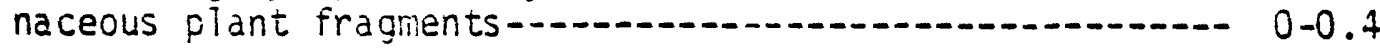

Coal, very impure, bony-1.-1

Shale $(\underline{6 P-32})^{*}$, medium-gray, partly brown-tinted, poor platybedded; abundant partiy randomiy oriented caroonaceous plant fragments; some large randomiy oriented wood

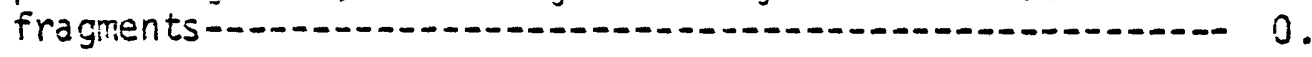

Coal, very impure, bony--

Sandstone, medium-gray to brownish-gray, friable, very

fine to fine-grained; many carbonaceous films-..........-- 0.2

Coal, Bed S, platy-weathering; mostly large flattened coalified wood remains -...-.-.- 5

Sandstone, medium-iight-gray, steep fairiy smooth slopeforming, locally cliff-forming, platy- to thin-bedded, cross bedded (sets less than $2 \mathrm{ft}$. thick), mostly friable, locality strongly iron-cemented in thin beds and lenses up to $0.5 \mathrm{ft}$. tnick, medium- to coarsegrained in basa? I it., mostly fire-grained, very fine grained in upper $6 \mathrm{ft}$., subangular to subrounded, very clayey in uper $2 \mathrm{ft.;}$; abundant small carbonaceous plant fragments randomly oriented in upper $2 \mathrm{ft}$.; scattered very carbonaceous laminae; lower contact

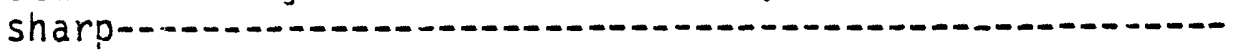

Coal, blocky to platy; upper $0.3 \mathrm{ft}$. impure; many large coalified wood fragments; $0.35-\mathrm{ft}$. lenticular parting $1.2 \mathrm{ft}$. above base of brownish-gray sandy clayey pyroclastic(?) siitstone; 0.1-ft. parting of dark-brownishgray to dark-gray carbonaceous shale at $0.3 \mathrm{ft}$. below

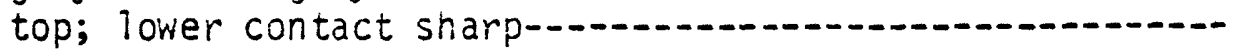


Siltstone, medium-gray, chunky-weathering, obscurely bedded, hard, clayey, mostly sandy; abundant randomly oriented carbonaceous plant fragrents; fel large randomiy oriented plant remains; lower contact gradational-..................

Sandstone, medium-gray, siabby-weathering, obscurely thinbedded, very fine grained, very clayey; some carbonaceous plant fragments; jew long plant remains extend into this unit from underiying siltstone; lower contact

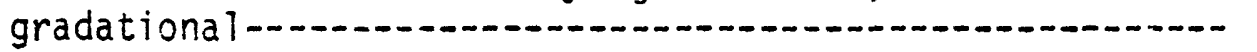

Siltstone, redium-gray, chunky - to hackly-weathering, obscurely bedded, clayey; common rardomiy oriented carbonaceous plant fragments; one long piant fragment about $0.05 \mathrm{ft}$. in diameter extends upward into the overlying

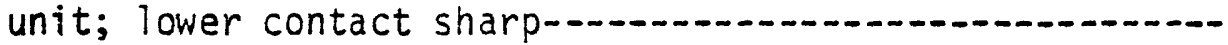

Siltstone, brownish-gray, platy-weathering, locally ledgeforming, fissile to platy-bedded, ciayey; abundant plant fragments on bedding; loiver contact fairiy sharp-.......- 0.6

Siltstone, medium-gray to parily brownish-gray in upper $0.3 \mathrm{ft}$., churky-weathering, obscurely bedded, clayey; many randomly oriented carbonaceous piant fragments; lower contact fairly sharp

Sandstone, medium-gray, partiy iron-stained, slabby-weathering, very thin bedded, fairly friable, very fine grained, subangular to subrounded; many carbonaceous laminae;

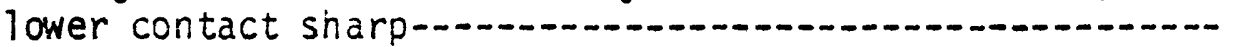

Siltstone, medium-gray, chunky- to poor slabby-weathering, obscurely bedded, very clayey, sandy in iower $3 \mathrm{ft}$.; common randomiy oriented carbonaceous plant fragments; includes few ironstone nodules up to $0.3 \mathrm{ft}$. thick at $0.2 \mathrm{ft}$. above base; lower contact sharp-..................

Sands tone, medium-gray, poor slabby-weathering, obscurely platy-bedded, friable, very fine grained, subangular to subrounded; lower contact sharp-.......................... 1.5

Siltstone, medium-gray, poor platy- to slabby-weathering, obscurely thin-bedded, clayey, sandy in upper $0.5 \mathrm{ft}$.; carbonaceous plant fragments locally cormon; includes ironstone nodules uD to $0.2 \mathrm{ft}$. thick near middle; lower contact gradational-a.

Sandstone, medium-gray, obscurely bedded, very fine grained, very clayey; poorly exposed; lower contact gradational-.- 4.6 
Siltstone, medium-gray, probably chunky-weathering, obscurely bedded, clayey; few carbonaceous plant fragments; pcorly exposed; lower contact gracational-........ 1.8

Sandstone, medium-gray, very thin bedded, slightly friable in part, very fine grained, subangular to subrounded, cl ayey-_-_.-. 2.5

Siltstone, medium-gray, thin-bedded(?), sandy; locally abundant carbonaceous plant fragments; includes few very fine grained sandstone Taminae; lower contact gradational-_-..-.

Sands tone, medium-gray, slabby-weathering(?), friable, very fine to fine-grained, subangular to subrounded; poorly

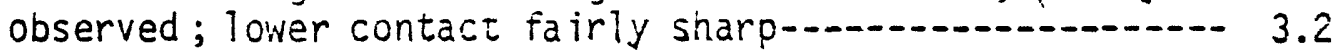

Sandstone, medium-gray, piaty-weathering, iaminated, very

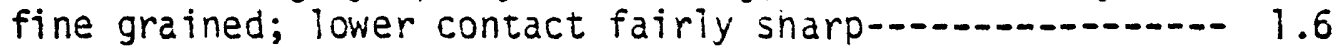

Siltstone, medium-gray, partly iron-stained, very thin bedded(?), clayey; few small carbonaceous plant fragments; includes ironstone nodules up to $0.2 \mathrm{ft}$. thick about $0.5 \mathrm{ft}$. below top; lower contact

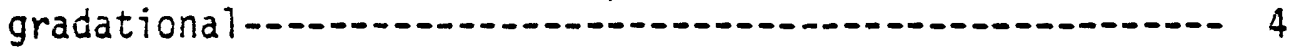

Shale $(\underline{6 P-22})^{*}$, medium-gray, poor platy-weathering(?), poor platy-bedded to fissile; abundant plant fragments --.---.-1.

Coal, platy, bony; abundant large coalified wood fragments; includes $0.2-\mathrm{ft}$. lense of medium-brown clayey silts tone at $0.5 \mathrm{ft}$. below top; 0.i-ft. Tenticuiar parting of

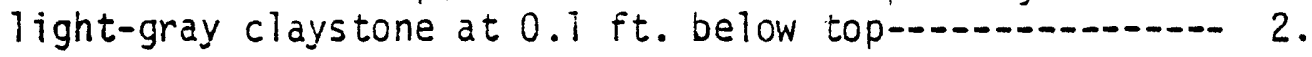

Sandstone and interbedded siltstone; sands tone, mediumgray, s?abby-weathering, very thin bedded, partly friable, very fine to fine-grained, subangular to subrounded; silts tone, medium-gray to brownish-gray, poor platy - to slabby-weathering, obscurely bedded, clayey, sandy; locaily abundant carbonaceous material and plant fragments; unit includes many large randomiy oriented coalified wood fragments in upper $1.5 \mathrm{ft} . \ldots . . . .44$.

Siltstone, brownish-gray, clayey; abundant plant remains-....- 0.2 Shale, dark-gray to black, fissile, carbonaceous; lower

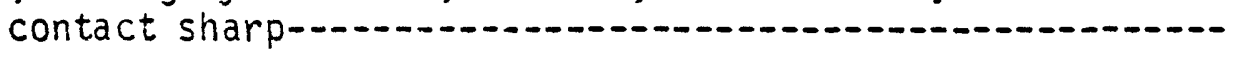


Sandstone, medium-gray, poor platy - to siabby-weathering, very thin bedded, cross-bedded, friable in middie part, very fine grained to partly fine-grained, very silty in upper part; few large carbonaceous wood fragments in upper part; lower contact covered-...........-

Sandstone and interbecded siltstone; sandstone, mediumgray, piaty-weathering, platy - to very th in bedded, very fine grained; silts tone, medium-gray to brownishgray, poor platy-weathering, very thin bedded, partly sandy, clayey; locally abundant carbonaceous plant fragments; forms beds about $0.5 \mathrm{ft}$. thick and makes up about 20 percent of unit; unit includes at top a brownish-gray siltstone bed with abundant carbonaceous

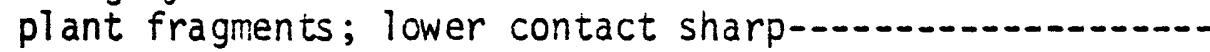

Siltstone, medium-iight-gray, slightly brownish-tinted, even-textured, piaty - to shard-like-weathering, very thin to platy-bedded, friable, pyroclastic; lower contact sharp-1...-

Shale, medium-gray, obscurely bedded; few plant fragments; grades to medium-gray clayey siltstone in upper 0.5 ft.; includes at $0.5 \mathrm{ft}$. below top $0.1-\mathrm{ft}$. bed of brownish-gray platy-bedded clayey carbonaceous siltstone with abundant piant fragments; lower contact gradational-a.-

Silts tone and interbedded sandstone; siltstone, mediumgray, very thin bedded, clayey, sandy; locally common plant fragments; sandstone, medium-gray to brownishgray, slabby - to poor platy-weatnering, very thin bedded, very fine grained; occurs in beds up to 0.5 $\mathrm{ft}$. thick in basal $2 \mathrm{ft}$.; upper part of unit weathers poor platy to chunky; lower contact gradational-.........

Sandstone and interbedded silts tone; sands tone, medium-gray, poor slabby-weatnering, obscurely bedded, probably very thin bedded, very fine grained, very silty; siltstone, brownish-gray, poor platy-weathering, very thin bedded, clayey; comion plant fragments; includes at $4 \mathrm{ft}$. above base 1-ft. bed of medium-gray obscurely bedded shale with few randomly oriented carbonaceous plant fragments; at $5 \mathrm{ft}$. above base 0.2-0.3 ft.-bed of brownish gray obscurely bedded snale with common plant fragments;

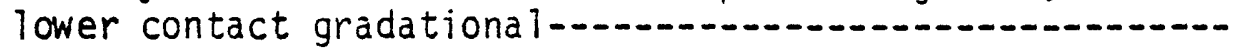


Siltstone, medium-gray, slabby-weathering, poor platy- to very thin bedded, clayey; some carbonaceous plant fragments -

Sandstone and interbedded siltstone; sands tone, medium-gray, 1 aminated to very thin bedded, very fine to finegrained, silty, clayey; abundant carbonaceous material on bedding in basal $0.4 \mathrm{ft}$.; silts tone, medium-gray, probably laminated to platy-bedded, clayey; carbonaceous plant fragments; unit weathers slabby; lower contact sharp-...-.

Sandstone, medium-gray, slabby-weathering, obscurely bedded, probably cross-bedded, friable, fine- to very coarse grained with many granules in lower part becoming fineto medium-grained in upper part, slightly clayey; includes in lower half many lenses and clasts up to $0.3 \mathrm{ft}$. thick of brownish-gray clayey siltstone with some carbonaceous plant fragments; unit wedges out in about $10 \mathrm{ft}$.; lower contact sharp, irregular, and .probably disconiormable-_......

Sandstone, medium-gray, light-brown iron-stained, obscurely bedded, friable, fine-grained; few fairly large caroonaceous plarit fragments near base; includes at top $0.1-\mathrm{ft}$. bed of medium-dark-gray fine- to coarsegraired sandstone; few siltstone lenses in lower 0.5 ft.; thickness of unit increases to $3 \mathrm{ft}$. in a distance of about $6 \mathrm{ft}$. 1aterally; lower contact sharp-........-.-

Siltstone, medium-gray, iron-stained in $0.1-\mathrm{ft}$. interval about $0.1 \mathrm{ft}$. below top, chunky-weathering, obscurely bedded; some carbonaceous plant fragments; includes few thin beds of very fine grained clayey sandstone in lower $0.5 \mathrm{ft.}$

Shale, medium-gray, obscurely bedded; many carbonaceous plant fragments; some slickensides in lower half; lower contact sharp-

Silts tone, brownish-gray, partly iron-stained, clayey; many small carbonaceous plant fragments; lower contact gradational-a.-.

Sandstone, medium-gray, obscurely bedded, very fine grained, subangular to subrounded, silty, clayey; few carbonaceous plant fragments; becomes silts tone in upper $0.2 \mathrm{ft}$.;

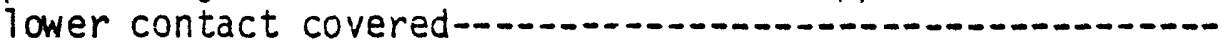


Covered interval; lateraily consists of sandstone and silt-

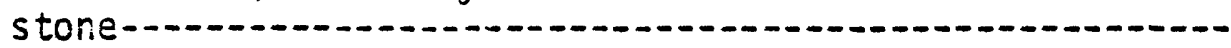

Sands tone, medium-gray, slabby-weathering, obscurely bedded, friable, very fine grained, anguiar to subangular;

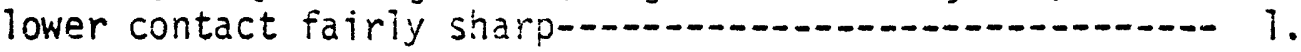

Siltstone, medium-gray, chunky-weatheriric, obscurely bedced, clayey; scattered sand grains; some carbonaceous plant fragments; lower contact covered-........................... 1.8

Covered interval; laterally consists of sandstone and si?t-

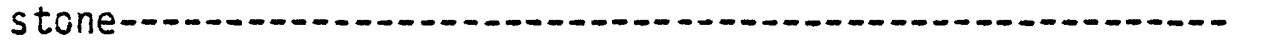

Siltstone, medium-gray, poor platy-weathering, iaminated to poor platy-bedded, clayey; many carbonaceous plant fragments in a few thin beds; upper $1 \mathrm{ft}$. grades to laminated very fine grained silty sandstone with rany

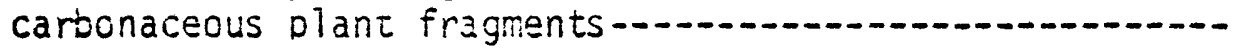

Coai and interbedided lenticular shale; ccal, platy-weathering; abundant large coalified wood remains; forms 5 beds up to $0.9 \mathrm{ft}$. thick; shale $(\underline{6 P-T}$-- from highest shale in unit) *, medium-light-gray, Tignt-gray-weathering, mostly poorly bedded to nonibecded; abundant carbonaceous plant fragments; scattered to common large coalified wood fragrients; locaily few leaf impressions; forms deds up to $1.3 \mathrm{ft}$. thick; unit includes brownish-gray piaty-bedded shale with many carbonaceous plant fragments at 0.1-0.5 ft. above base; lower contact sharp; unit equivalent to uppermost coal and shale unit in measured section 11

6.

Siltstone, medium-light- to medium-gray, partiy brownishgray in upper part, cnunky- to poor platy-weathering, laminated to very thin bedded, poorly bedded in upper 0.7 ft., clayey; many caroonaceous piant fragments; some large randomiy oriented coaly plant fragments in upper $1.3 \mathrm{ft}$.; few leaf impressions in lower half; includes at base 0.3-ft. bed of medium-gray laminated very fine grained very ciayey sandstone; lower contact sharp-..-...

Shaie, medium- to medium-dark-gray and brownish-gray, chunkyweathering, poor platy-bedded: abundant carbonaceous plant fragments; includes at base $0.4-\mathrm{ft}$. bed of mediumgray poorly bedded shale; lenses of medium-light-gray and medium-brownish-gray shale about $0.5 \mathrm{ft}$. above base;

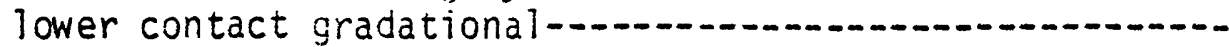


Sands tone and interbedded silts tone; sands tone, medium-gray, laminated to very thin bedded, very fine grained, subanguiar to subrounded; locally abundant carbonaceous plant fragments on bedding; siltstone, medium-gray, chunky - to poor platy-weathering, obscurely bedded, clayey; few carbonaceous plant fragments; unit includes friable very fine grained sandstone beds up to $0.2 \mathrm{ft}$. thick in upper $4.5 \mathrm{ft}$.; lower contact fairly sharp-1.-1 14.6

Sandstone and interlaminated bone coal; sandstone, mediumgray, fissile to platy-weathering, very fine grained, subangular to subrounded; lower contact sharp-............ 1 .

Siltstone, medium-gray, chunky - to poor platy-weathering, obscurely bedded, probably very thin beaded, clayey, very sandy at base; few carbonaceous plant fragments; lower contact gradational-a. 3.6

Sandstone, medium-gray, obscurely very thin bedded, friable in lower part becoming less friable upward, very fine to fine-grained, angular to subangular, micaceous;

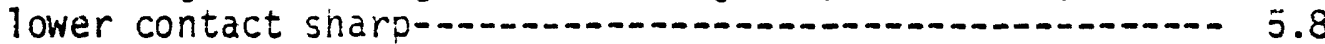

Sands tone, medium-gray, platy-weathering, laminated to very thin bedded, poorly friable, very fine grained, subangular to subrounded; large coalified wood fragments (possibly roots in growth position); some large coaly fragments extend into underlying siltstone; lower con-

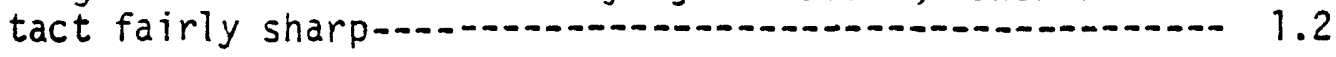

Siltstone, medium-gray, mostly platy-weathering, some fissileweathering, fissile to platy-bedded, ciayey; abundant carbonaceous plant fragments; includes carbonaceous beds and lenses up to $0.1 \mathrm{ft}$. thick; few very thin beds or lenses of bone coal; lower contact sharp-................ 3.

Sands tone, medium-gray, slabby-weathering, very thin bedded, friable, very fine grained, subangular to subrounded, silty; includes bone coal stringers at base; lower

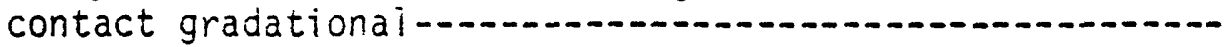

Silts tone, medium-gray, poor platy-weathering, obscurely poor platy - to very thin bedded, clayey; abundant carbonaceous plant fragments on bedding; lenses of carbonaceous siltstone, up to $0.1 \mathrm{ft}$. thick, interbedded with bore coal about $0.2 \mathrm{ft}$. below top; lower contact covered at forks of Swift Creek-..................... 1.+ 


\section{Measured section 7}

Location: Hillside exposure on northwest side of Fox Creek about 50$200 \mathrm{yd}$. upstream from molith of southeast flowing tributary (locally known as Danny (reek.) in E $1 / 2 \mathrm{SW} 1 / 4 \mathrm{NW} 1 / 4 \mathrm{sec}$. 33, T. $3 \mathrm{~S}$., R. 10 W., Seldovia $0-3$ quadrangle.

Feet

Pleis tocene gravel 10.

Unconformity

Tertiary rocks -- Kenai Group, Sterling Formation

Shale and interbedded siitstone; shale, medium-gray to light-

olive-gray, partly iron-stained, deeply-weathered, clayey, siity; siltstone, medium-gray to iight-olivegray, partly iron-stained, deepiy weathered, clayey--.--- 4.

Sandstone, medium-gray, largely iron-stained, obscurely bedded, soft, friable, very fine grained, subrounded, well sorted; includes $1.5-\mathrm{ft}$. bed of medium-gray siltstone near middle; ironstone nodules iess than 0.1

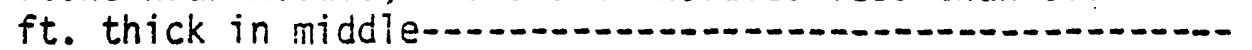

Silts tone, medium-gray, partly iron-stained, deeply ironstained in upper $0.1 \mathrm{ft}$., partly olive-gray-weathering, mostly obscurely bedded, partly laminated to very thin bedded in middle, largely very clayey; small

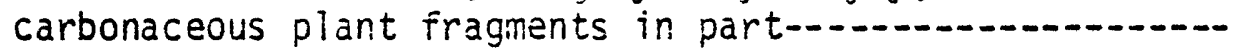

Sandstone, medium-gray, slabby-weathering, obscurely bedded, laminated in part, soft, mostly friable, very fine grained, subangular, very silty; becomes siltstone in upper $1 \mathrm{ft}$.; includes few very thin lenses and beds of medium-gray shale in lower $1.5 \mathrm{ft}$.; lower contact sharp-

Shale, medium-gray, poor platy- to hackly-weathering, obscurely bedded, clayey; small plant fragments common in upper part; incluces few very thin to thin interbeds of medium-gray partly iron-stained siltstone; lower contact gradational 
Sandstone, medium-gray, largely iron-stained, slabbyweathering, obscurely very thin bedded, mostly friable, very fine to fine-grained, subangular, very silty, clayey; includes few beds of medium-gray siltstone and saridy shale up to $0.5 \mathrm{ft}$. thick in lower 3 ft.; few ironstone nodules less than $0.1 \mathrm{ft}$. thick in siltstone bed $1.5 \mathrm{ft}$. adove base; lower contact gradationa 1--..-.

Shale, medium-dark-bluish-gray, scme light-gray laminations near middle, mostly obscurely bedded with some platy bedding near middle, siity; grades to siltstone in upper $0.2+t$.; common smali piant fragments; includes 1.5-ft. bed of medium-dark-biuisn-gray very fine grained very silty sandstone at base; 0.4-ft. bed of mediumgray friable very fine grained sands tone $0.8 \mathrm{ft}$. below

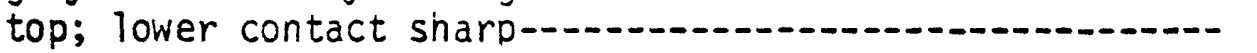

Siltstone and interbedded sandstone; siltstone, mediumgray, slabby-weathering, oiscurely bedded, clayey, abundant small carbonaceous plant fragments; sandstone, medium-gray, slabby-weathering, obscure?y bedded, very fine to medium-grained, poorly sorted, very clayey;

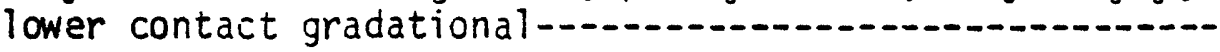

Shale and interbedded siltstone; shale $(7 P-55)^{*}$, mediumgray, obscureiy bedded, clayey, si ty; many small plant fragments; siitstone, medium-gray, hackly-weathering, obscurely bedded, clayey, sandy in lower part; inciudes few very thin beds of medium-gray very clayey fine- to medium-grained sandstone; lower contact sharp-..-...-...---

Sandstone, medium-dark-bluish-gray, partly iron-stained, slabby-weathering, obscurely bedded, friable, fineto coarse-grained in iower bart becoming fine- to mediumgrained with scattered coarse grains in upper part, poorly sorted, very silty, very clayey; includes abundant dark-gray fine- to coarse-grained shale flakes; very thin lenses of medium-dark-gray shale about $1 \mathrm{ft}$.

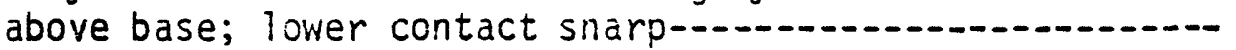

Shale, dark-gray, platy-wea thering, poor blocky-weathering in lower $0.3 \mathrm{ft}$., poor fissile to platy-bedded, carbonaceous; upper half becomes less carbonaceous and includes many fine-grained particies of 1 ight-brownishgray volcanic ash and pumice(?); lower contact sharp---- 0.9 
Siltstone, medium-dark-bluish-gray, hackly-weathering, obscurely bedded, very clayey especiaily in upper part; plant fragments cormon in part; lower contact

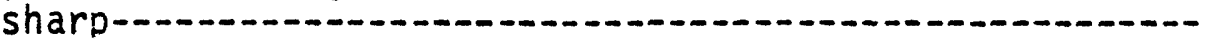

Sandstone, medium-dark-bluish-gray, slabby-weathering, obscurely bedded, fairiy friable, very fine to finegrained, subangular to subrounded, very silty, very clayey; includes few large weathered biotite flakes and abundant dark-gray phyllitic shale flakes; 0.1 ft. siltstone bed in middle; poorly observed; lower

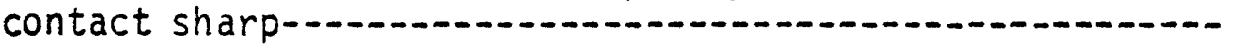

Siltstone, medium-dark-bluish-gray, hackly-wea thering, obscurely bedded, clayey to very clayey in upper

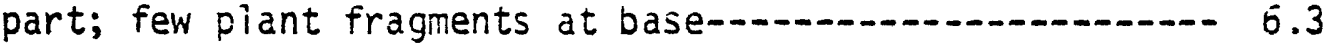

Sandstone, medium-dark-bluish-gray, partly iron-stained, slabby-weathering, partly obscurely very thin bedded and cross-bedded, friable, very fine grained, subangular, ciayey, very siity; includes very thin siltstone interbeds or lenses; lower contact gradational-...- 8.3

Siltstone, medium-gray, partly iron-stained, mostly obscurely bedded but partly laminated, sandy to very sandy in upper part-.....

Coal, platy-weathering, bony; includes light-gray mediumgrained pyroclastic(?) grains; prodably tuff or devitrified pumice--...-

Sandstone, medium-dark-bluish-gray, slabby- to partly poor platy-weathering, obscurely very thin bedded, soft, very fine grained, subanguiar, very silty; includes 3 beds of medium-gray sandy siltstone $(0.5-\mathrm{ft}$. bed near middle, $0.2-\mathrm{ft}$. bed $0.5 \mathrm{ft}$. below top, and $0.3-$ $\mathrm{ft}$. bed about $1.5 \mathrm{ft}$. above base)

Shale and interbedded siltstone; shale, medium-dark-bluishgray, obscurely bedded, silty; few plant fragments and large coalified wood remains; silts tone, medium-gray, hackly-weathering, obscurely bedded, sandy; includes few very thin beds of medium-gray friable very' fine

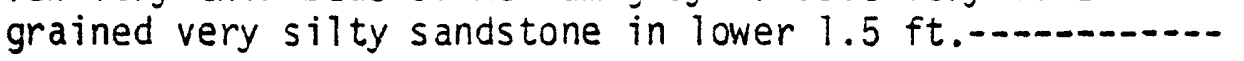

Shale, medium-dark-bluish-gray, obscurely bedded, silty; few plant fragments and large coaly wood remains at top--1.-.- 
Coal, very impure; includes some large woody remains; includes several lenses up to $0.1 \mathrm{ft}$. thick of lightbrown to light-brownish-gray siltstone with abundant light-gray grains of tuff or devitrified pumice; lower contact sharp-... 0.8

Shâle, medium-gray, hackly-weathering, obscurely bedded, silty, partly sandy in lower half; carbonaceous plant fragments common in part; lower contact fairly sharp-...- 3.6

Sandstone, medium-gray, obscurely bedded, mostly friable, very fine grained, very silty, shaly in basa? part;

lower contact gradational-.......... 1.2

Shale, medium- to medium-light-gray, hackly-weathering, obscurely bedded, silty; carbonaceous plant fragments abundant in basal $0.3 \mathrm{ft}$. and scattered elsewhere in

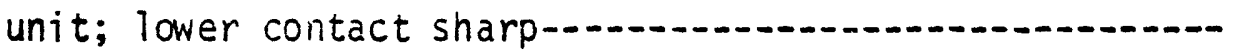

Siltstone, medium-brown to brownish-gray, platy-weathering, poor platy-bedded; many carbonaceous plant fragments on bedding; includes light-gray grains of tuff or de-

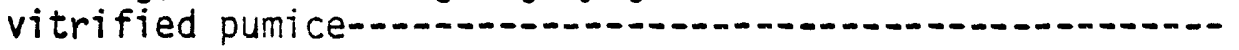

Coal, du11, impure; upper two-thirds of unit grades laterally into medium-irown sandy siltstone with abundant lightgray grains of tuff or devitrified pumice; lower contact sharp-...-

Shale, medium-gray to medium-dark-bluish-gray, hacklyweathering, obscurely bedded, silty; scattered plant fragments randomiy oriented; includes very thin interbeds of medium-gray siltstone in lower $1 \mathrm{ft}$.; lense up to $0.15 \mathrm{ft}$. thick of brownish-gray coaly shale near

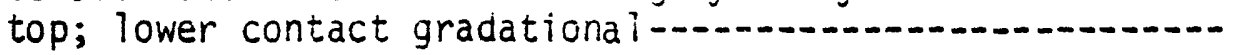

Sandstone, medium-dark-bluish-gray, fine- to medium-grained in lower $1 \mathrm{ft}$. becoming fine-grained in middle and very fine grained in upper part, subangular, clayey, very silty; includes abundant dark-gray shale flakes;

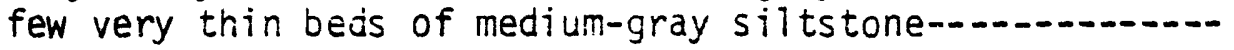

Siltstone and shale; siltstone, medium-gray to medium-darkbluish-gray, vcscurely bedded, very sandy; shale, medium-gray, obscurely bedded, very silty; some carbo-

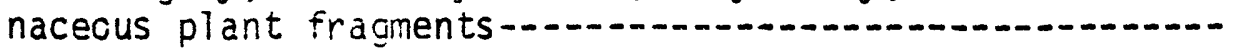


Sands tone, medium-dark-bluish-gray, slabby-weathering, obscurely bedded, friable, very fine to finegrained with scattered medium grains near middle, subangular, clayey, very silty; abundant dark-gray shale flakes; plant remains near middle; includes $0.2-\mathrm{ft}$. medium-gray siltstone bea $0.5 \mathrm{ft}$. below top; several very thin beds or lenses of siltstone-............ 4.

Shale, medium-gray, obscurely bedded; abundant small plant fragments; scattered large wood fragments; lower contact sharp--

Sandstone, medium-gray, obscurely bedded, friable, very fine to fine-grained, subangular, clayey, very silty; many small dark-gray shaie flakes; abundant plant fragments in top $0.2 \mathrm{ft}$.; includes few very thin beds or lenses of medium-gray siltstone; lower contact sharp-............ 4.

Shale, medium-gray; abundant large coalified tree remains; includes few very thin lenses of medium-gray to mediumdark-bluish-gray friable very fine to fine-grained.

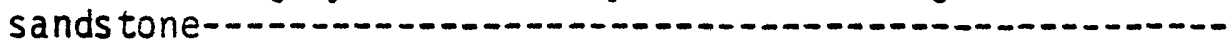

Sandstone, medium-dark-bluish-gray, partly iron-stained, slabby-weathering, obscurely bedded, soft, friable, very fine grained with the upper $1 \mathrm{ft}$. becoming mainly siltstone, subangular, clayey, very silty; many small dark-gray shale flakes; few large plant fragments; includes some very thin interbeds of medium-gray siltstone; lower contact gradational

Sands tone and interbedded siltstone; sandstore, mediumdark-bluish-gray, slabby-weathering, obscurely bedded, very fine grained, subangular, clayey, very silty; siltstone, medium-dark-biuish-gray, slabby-weathering, obscurely bedded, clayey; some large coaly wood fragments near middle; lower contact gradational-............- 2.2

Shale, medium-gray to medium-dark-bluish-gray, obscurely bedded, very silty; some carbonaceous plant fragments; few large plant fragments near top; lower

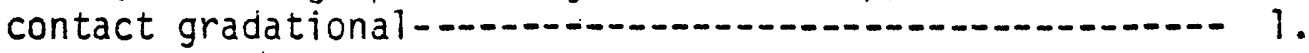

Shale, medium-gray to medium-dark-bluish-gray, chunky - to poor platy-weathering, obsclurely bedded, very silty; scattered to abundant very fine grained white to clear feldspar crystals and pumice(?) fragments in lower two-

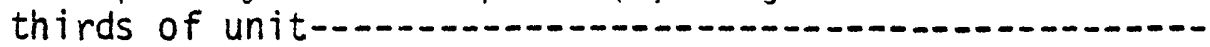


Shale, medium-gray, hackly-weathering, obscurely bedded, silty; common carbonaceous plant fragments; lower con-

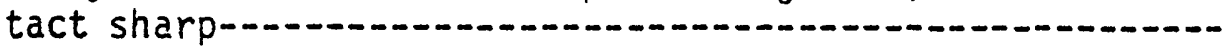

Siltstone, brownish-gray, poor platy-weathering, poor platy - to very thin bedded, very sandy, microbreccia; includes abundant olive-gray and dark-gray meciumgrained shale flakes and light-gray pumice(?) frag-

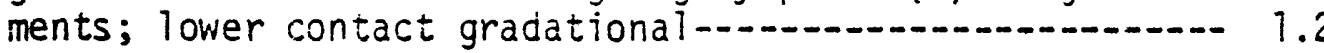

Sands tone, medium-dark-bluish-gray, slabby-weathering, obscurely bedded, friable, fine- to medium-grained, subangular, very clayey in upper $0.3 \mathrm{ft}$., very silty; abundant dark-gray medium- to fine-grained shale

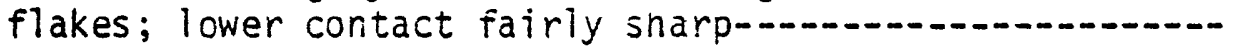

Sandstone, medium-dark-biuish-gray, partly platy- to very thin bedded, partly cross-bedded, fairly friable, fine- to medium-grained, scattered coarse grains in lower $4.5 \mathrm{ft}$., subrounded to subangular, ciayey, very silty; subequal quantities of monomineralic grains and dark-gray shale flakes; scattered coalified wood remains in lower part; includes many lenses up to $2 \mathrm{ft}$. thick of medium- to very coarse grained sandstone with scattered to abundant granules between $4.5 \mathrm{ft}$. and 21 ft. above base; abundant medium-gray shaie flakes up to $0.03 \mathrm{ft}$. thick in $0.3-\mathrm{ft}$. bed $0.5 \mathrm{ft}$. above base; unit locally forms steep bare rounded slopes; lower contact sharp--.-.--..-..-

Shale and interbedded sandstone; shale, medium-gray, hacklyweathering, obscureiy bedded, silty; includes some brownish-gray poor piaty-bedded clayey shale with abundant plant fragments; sandstone, medium-gray, partly iron-stained, fine- to medium-grained; includes shale flakes and shale lenses less than $0.1 \mathrm{ft}$. thick; unit includes large carbonaceous wood remains; lower

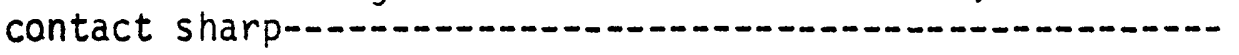

Shale, medium-gray to medium-dark-bluish-gray, hackiyweathering, obscurely bedded, silty; some small plant

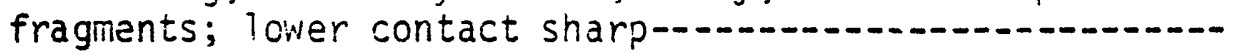

Sands tone, medium-dark-bluish-gray, slabby-weathering, obscurely bedded, friable, very fine to fine-grained, subangular, clayey, very silty; abundant smali darkgray shale flakes; lower contact gradational ................ 
Siltstone and interbedded sandstone; siitstone, mediumgray, very thin bedded, partiy platy-bedded, very clayey; sandstone, medium-gray, slabby- to poor platy-weathering, very thin bedded, friable, very fine grained, subangular, clayey, very silty; few small dark-gray shaie

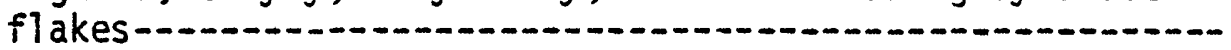

Shale, medium-gray, hackly- to conchoidal-weathering, obscurely bedded, tough, compact, silty; few carbonaceous plant fragments; many large coailified tree remains at base and top; lower contact fairly sharp-................ 1.5

Siltstone, medium-gray, slabby-weathering, obscurely bedded, sandy to very sandy in upper half; includes few thin beds of medium-gray friable very fine grained clayey very silty sandstone; lower contact gradational-...-.-.-- 9.6

Siltstone, medium-gray, slabby-weathering, obscurely bedded, partly sandy, clayey at base; abundant carboriaceous

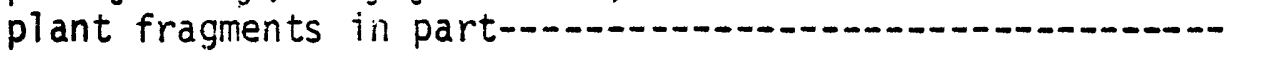

Shaie, medium- to medium-dark-gray, poor fissile to platybedded, cartonaceous; abundant plant fragments; includes fissile bone coal stringers; 0.02-ft. Tense near middle of light-gray fine- to medium-grained sandstone with clear feldspar crystal fragments and grains of light-gray devitrified pumice(?) and/or tuff; lower contact gradational-1.--

Shale, medium-gray, poor platy-bedded to fissile in part, silty; abundant small carbonaceous fragments; lower contact fairly sharp-a.

Shale and interbedded carbonaceous shale, medium- to darkgray, deeply weathered, fissile; abundant plant fragments and large carbonaceous wood remains; poorly developed vertical cieat and the appearance of coal;

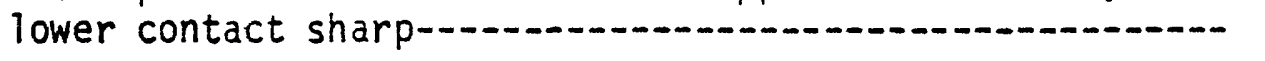


Siltstone, medium-gray, partly brownish-gray, poor platyweathering in lower part and s? abby- to hackiy-weathering in upper part, platy-bedded in lower part to obscurely bedded in upper part, very clayey in upper $0.5 \mathrm{ft}$.; sore leaf imoressions in part; large carbonaceous wood remains $10 c a 17 y$ abundant in $0.2-\mathrm{ft}$. interval $0.5 \mathrm{ft}$. beloiv top; includes brownish-gray beds with abundant fine grains of light-gray devitrified pumice(?) and clear feldspar and glass(?) in a 1-ft. interval $1.5 \mathrm{ft}$. above base; some slickensides in lower part; few dark-gray to black carbonaceous shale beds less than $0.1 \mathrm{ft}$. thick in lower part; lower contact gradational-1...-...-.

Shale $(7 P-28) *$, medium-gray, hackly-weathering, obscurely beddea, silty; common carbonaceous plant fragments;

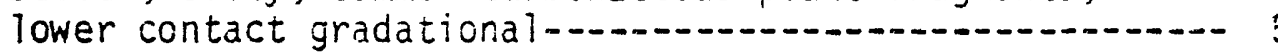

Siltstore, medium-gray, slabby- to poor platy-weathering, platy-bedded, soft, clayey; few carbcraceous plant fragments; includes severai beds up to $0.5 \mathrm{ft}$. thick, of medium-gray friatie very fine grained subanguiar sandstone; unit pooriy exposed; lower contact sharp-.....- 12.

Sandstone, medium-gray, very thin bedded, cross-bedded, friable, fine- to medium-grained in lower $2 \mathrm{ft}$. becoming fire-grained asove, subanguiar, silty; few leaf impressions $6 \mathrm{ft}$. above base; includes abundant biack rock fragrients; few thin beds and lenses of p? atyweathering iron-rich sandstone; thin beds of mediumgray laminated siltstone in upper $2.5 \mathrm{ft}$.; unit locally a poor cliff former; lower contact fairly sharp--..-.-

Sandstone, medium-gray, foor platy- to siaboy-weathering, platy - to very thin bedded, partly friaule, very fine grained, subanguiar, very silty; inciudes a few very thin interbeds of medium-gray sandy siltstone; lower

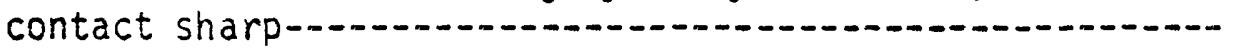

Siltstone and interbedded sandstone; siltstone, mediumgray, platy-bedded, clayey, partly calcareous; sandstone, medium-gray, Dartiy iron-stained, platy- to very tnin bedded, friabie, very fine graired, subangular; includes $f \in w$ thin beds of mediumi-gray snaie; lower contact sharp 
Sandstone, medium-gray, iron-stained, slabby-weathering, obscurely bedded, friable, very rine grained, subangular, very silty; common small dark-gray snale

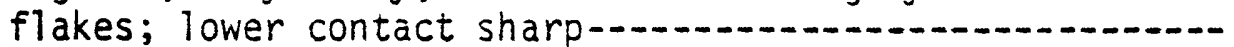

Siltstone, medium-dark-bluish-gray, slabby - to poor platyweathering in upper $1.5 \mathrm{ft}$, coscurely bedded, clayey in upper $1.5 \mathrm{ft}$; few plant fragments in lover haif; includes very thin beds of friable very fine grained sandstone in 1 -ft. interval near middle; $0.1-f t$. bed of light-brownish-gray ciaystone about $3 \mathrm{ft}$. beiow top; lower contact gradational-a

Sandstone, medium-gray to medium-dark-bluish-gray, partiy iron-stained, slabby-weathering, obscurely bedded, partly platy- to very thin becded, partly cross-bedded, mostly friabie, very fine graired, subangular; very clayey, very silty; incluces few fine- to mediumgrained sandstone interbeds up to $1 \mathrm{ft}$. thick; $0.5-\mathrm{ft}$. bed of mediumi-gray sandy si? ts tone about $3 \mathrm{ft}$. above base; lower contact sharp-1

Siltstone, medium-gray, partly iron-stained, slabby- to poor platy-weathering, partiy platy - to thin-bedded, somewhat uneven-bedded, partly sandy; locailly cormon piant fragments; coalified tree remains in $0.5-\mathrm{ft}$. interval near middle; includes few in in beds of medium-gray friable very fine grained sandstone; becomes very shaly in upper $2 \mathrm{ft}$.; lower contact gradational-...................

Siltstone, medium-gray, slabby-weathering, obscurely bedded, even-textured, soft, sandy; iower contact fairiy sharp-.-

Shale (7P-21)*, medium-gray, obscurely bedded, very silty; abundant caroonaceous plant iragments in lower part; includes $0.6-\mathrm{ft}$. interval of orownish-gray shale in middle; bone-coal lenses up to $0.4 \mathrm{ft}$. thick and large carbonaceous wood remains; lower contact gradational-

Siltstone and interbedded sandstone; siltstone, medium-gray to medium-dark-bluish-gray, slabby-weathering, obscurely bedded, partiy sandy; sandstone, med:um-gray to medium-dark-bluish-gray, si acby weathering, doscurely bedded, friable, very fine grained; subangular, very silty, very clayey; forms ieds up to $i \mathrm{ft}$. thick in upper two-thirds of unit; lower contact sharp-...... 
Sandstone, medium-gray, slabby-weathering, poor platybedded, very fine grained, sucanguiar, clayey, very silty; includes in lower part interpedded silts tone and shale with many plant fragrients; $0.1-f t$. lense $0.5 \mathrm{ft}$. above base of dark-brownish-gray to darkgray shale with very thin lenses of yellowish-brown very fine grained particles of tuff or devitrified glass(?); lower contact gradational

Siltstone, medium-gray to medium-dark-bluish-gray, hackiyto poor slabby-weathering, odscurely bedded, sandy; some large wood remains; lower contact gradational-......- 1.6

Sandstone, medium-gray to medium-dark-bluish-gray, slabbyweathering, coscurely bedded, prodably piaty - to very thin bedded, very fine grained, subangular, very silty, very clayey; lower contact gradational $\ldots . . . . . . . . .-1.8$

Sandstone, medium-dark-oluish-gray, slabby-weathering, obscurely bedced to very thin bedried, cross-bedced. friable, mostly medium- to coarse-grained, some very coarse grains and granules in lower $3 \mathrm{ft}$., fine-grained in upper $1 \mathrm{ft}$., predominately composed of dark-gray shale flakes with scattered large shale flakes and several courses of large shale flakes in iower $3 \mathrm{ft}$.;

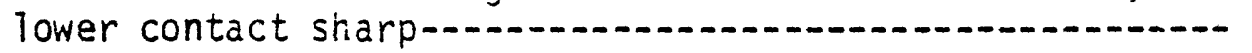

Shale, medium-gray, hackly - to poor slabby-weathering, obscurely bedied, ci iayey to very silty; plant fragments common in upper half and scattered in lower half..........

Sandstone, medium-dark-bluish-gray, partly iron-stained, slabby-weathering, obscurely bedded, friable, mediumto coarse-grained a $\tau$ base becoming very fine to finegrained at top, sudangular, very silty, very clayey; abundant dark-gray shale flakes; lower contact sharp-..-- 7.5

Shale and interbedded siltstone; shale, medium-dark-bluishgray, obscurely bedded, silty; some plant fragments; silts tone, medium-dark-bluish-gray, obscurely bedded, clayey, sandy; some blant fragments; unit weathers

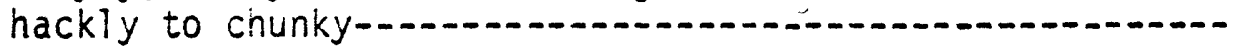

Siltstone, brownish-gray to medium-gray, poor platy-bedded, carbonaceous; many plant fragments; probably pinches

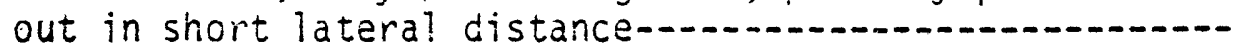


Sandstone, medium-dark-bluish-jray, sl abby-weathering, obscurely bedded, mostly friacle, medium- to coarsegrained in basal 1 ft. becoming fine- to medium-grained about $3.5 \mathrm{ft}$. above base, subangular, very silty, very clayey; composed mostly of dark-gray shale flakes; lower contact sharp and undulating-........................... 7.6

Shale, medium- to dark-gray, poor fissile to platy-bedded, very silty; many plant fragments on bedding surfaces;

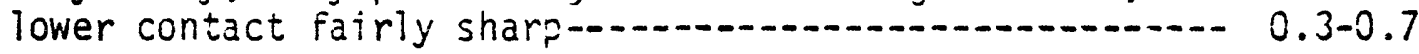

Sandstone, medium-dark-bluish-gray, obscurely bedied, very fine grained, subanguiar, silcy, very clayey; abundant dark-gray shale flakes; upper $0.5 \mathrm{ft}$. dominateiy siltstone; includes at $0.5 \mathrm{ft}$. below top iense less than $0.1 \mathrm{ft}$. thick of yellowisn-brown very fine grained very silty sandstone; lower contact fairiy sharp-........-

Sands tone, medium-dark-bluish-gray, slabby-weathering, obscureiy bedced, friable, very fine to firie-grained, subangular, very silty; abundant dark-gray shale

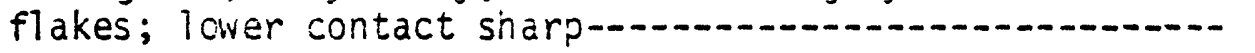

Shale $(7 P-13)^{\star}$, medium-gray, obscurely bedded, silty; some small plant fragments and large coalified wood remains; slickensided in part; lower contact sharp-.................. 1.1

Sands tone, medium-dark-bluish-gray, partly iron-stained (particularly in upper $1 \mathrm{ft}$. ), mostly slabbyweathering, friable in lower $3 \mathrm{ft}$., very fine to finegrained, clayey in upper $1 \mathrm{ft}$.; abundant dark-gray shale flakes; some large coaly wood fragments; lower

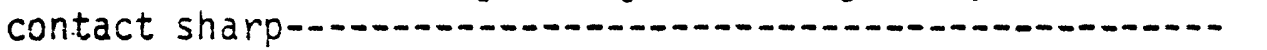

Siltstone, mottled medium-gray and brownish-gray in lower part to mostly dark-brownisn-gray in upper part, fissile- to cnunky-weathering, obscurely to poor platybedded in upper part, carbonaceous in part; fine grains of tuff, clear feldspar and devitrified glass(?); many carbonacecus plant fragments; includes lenses up to $0.3 \mathrm{ft}$. thick of medium-gray friabie fine-grained very silty sardstone in usper $1 \mathrm{ft}$.; lower contact gradationa $7-\ldots$

Siltstone, medium-gray, obscurely bedded, soft, sandy in upper $1 \mathrm{ft}$., clayey; some caroonaceous piant fragments and few large coalified wood remains in lower part;

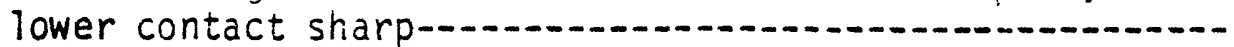

*Palynological samole 
Sands tone, medium-gray to medium-dark-bluish-gray, slabbyweathering, obscurely becded, friabie, very ine to medium-grained, upper $0.8 \mathrm{tt}$. mostly very fine grained, subangular, clayey, very silty, pooriy sorted; abundant dark-gray shale flakes; lower contact gradational--.----- 4.1

Siltstone and interbedded shale; siltstone, nedium-aray, obscurely bedded, silty, sandy; common randomiy oriented plant fragments; shaie, medium-gray, obscureiy bedded, very silty; common randomly oriented piant fracments; unit weathers slabby and includes very thin beds and lenses of medium-gray very fine to medium-grained sands tone

Siltstone and bone coal; siltstone, brownish-gray to mediumgray, poor fissile to platy-bedded, clayey, carbonaceous in part; many plant fragrents; coal, impure, weathered, lenticular; large coalified wood remains; lower contact gradational; unit probably squivalent to uppermost coal describud in measured section 10-........................ 1.

Siltstone, medium-gray, slabby- to hackly-weathering, obscurely bedded, clayey; iel sinall plant fragments; few large coaly wood fragments about $1 \mathrm{ft}$. above base and in upper $0.5 \mathrm{ft}$.; includes some interbedced shale

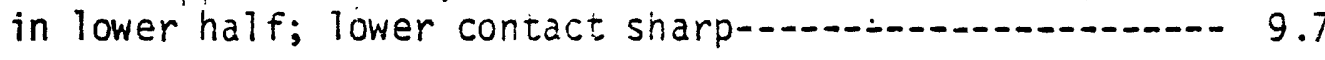

Siltstone, medium-gray becoming brownish-gray in upper part, platy-bedded and hard in upper nalf, mostly clayey, sandy in upper part; coalified wood fragments at top;

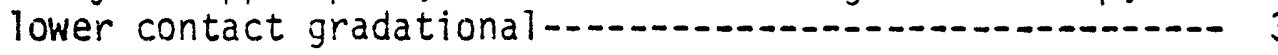

Sands tone, medium-dark-bluish-gray, slabby-wea thering, obscurely bedded, friable, medium- to coarse-grained in lower $3 \mathrm{ft}$. becoming mostiy medium-grained in middle part and very fine grained in upper 3 ft., subangular, clayey, very silty; abundant dark-gray shale flakes; lower part mostly covered -- pcorly exposed by trenching; lower contact sharp and probably disconformable...........

Note: The rocks described below are exposed in a steep hillside about 100 yd. southinest of the $32-\mathrm{ft}$. Sandstone described above. The sandstone is rostly covered across this distance, and correlation is based on the medium to coarse grain size and position on the hillside. 
Siltstone, medium-gray, cbscurely oedded, sandy in lower part, very clayey, slickensided; plant remains conmon; abundant light-gray grains and granules of tuff ard devitrified pumice; common ciear feldspar grains; solution cavities(?) in 1.5-ft. interval $1 \mathrm{ft}$. above base; $0.1-f t$. bed of brownish-gray carbonaceous siltstone at top; lower contact gradational; this unit apparently cut out to the nortieast by the overiying

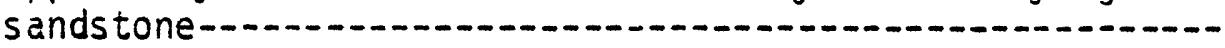

Sandstone, medium-gray, mostly iron-stained, slabbyweathering, partly very thin bedced, partly iaminated, soft, friable, very fine grained, subangular, very silty in upper part; includes a 2.5-ft. bed of medium-gray obscurely bedded siltstone near middie; poorly developed ironstone nodules at top; lower contact fairly sharp; upper part of this unit probabiy cut out to the north-

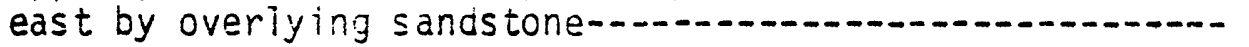

Siltstone, medium-gray, iron-stained, hackly-weathering, obscurely beddea, partly sancy; includes very tnin interbeds of meaium-gray platy-bedded iriable very fine to medium-grained very silty sandstore; scattered yellowish-brown soft poorly defined concretions up to $0.1 \mathrm{ft}$. thick; icwer contact gradational-...............- 7

Sands tone, medium-gray, slabby-weathering, platy - to very thin bedded, platy-bedded in lipeer $1 \mathrm{ft}$. , friable, very fine grained, subangular, clayey, very silty; common dark-gray rock fragments; lower contact fairly sharp---.--

Siltstone and interbedded sandstone; silts tone, medium-gray to medium-dark-oluish-gray, platy- to very thin oedded, soft, sandy; sarastone, medium-gray, platy - to very thin bedded, soft, very fine grained; unit weathers hackly; inciujes $0.1-f t$. bed of nedium-gray friable fine-grained sanistone 0.2 ft. celow top; lower contact

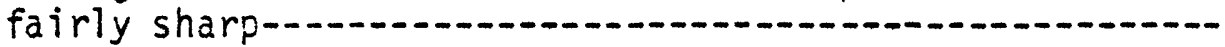

Siltstone, medium-gray to medium-dark-bluish-gray, hacklyweathering, obscurely bedded in lower half, platybedded to iaminated in upper nalf, clayey; includes 0.1ft. irregular bed of mottled yeilowish-brown siltstone $0.2 \mathrm{ft}$. below top; lower coritact gradational-................. 
Sandstone, medium-gray to medium-dark-bluish-gray, slabbyweathering, mostly obscurely bedided, partly very thin bedded, mostiy soft, partly friable, medium-gràined in basal $1 \mathrm{ft}$. becoming very fine grained above, subangular, clayey, very silty; lower contact sharp--.----- 6.5

Siltstone (7P-1 -- $3 \mathrm{ft}$. above base) ${ }^{*}$, medium-gray to mediumdark-bluish-gray, nackly-weathering in upper $4 \mathrm{ft}$., poor platy-weathering in upper 0.5 it., poor conchoidally fracturing, mostiy obscurely becded, platy-bedded in upper $4 \mathrm{ft}$., partiy laminated in upper $0.5 \mathrm{ft}$., soft, sandy, clayey; few plant fragments; common yeilowishgray partly limy clayey shaie flakes in a thin bed about $3 \mathrm{ft}$. above base; includes interbeds up to $1 \mathrm{ft}$. thick of medium-gray soft very fine grained sands tone; 0.2-ft. bed of medium-dark-gray platybedded to poorly fissile carbonaceous siltstone $5 \mathrm{ft}$. above base; lower contact concealed in Fox Creek-...-...-.- 


\section{Measured section 8}

Location: Hillside exposure in large unnamed west tributary of Fox Creek from SE corner SN 1/4 SE 1/4 sec. 7 southwärd to SW 1/4 NE $1 / 4$ NE $1 / 4 \mathrm{sec}$. 18, T. 4 S., R. 10 'w. , Seldovia D-3 quadrangle. This location is approximately the same as locality 172 of Barnes and Coib $(1959$, pls. 18, 19). Section starts abolit $15 \mathrm{ft}$. below canyon rim.

Feet

Tertiary rocks-Kenai Group, Sterling Formation

Siltstone $(8 \mathrm{P}-95$-- middle part)*, medium-gray, mostly lightolive-gray-weathering, partly iron-stained, chunkyweathering, obscurely bedded, clayey, sandy in basal $1 \mathrm{ft}$.; abundant caroonaceous plant fragments; clayey ironstone nodules $0.1 \mathrm{it}$. thick abcut $3.5 \mathrm{ft}$. above base; overlain by deeply weathered silicstone and soil; lower contact gracacional-_.....

Sandstone, medium-light-gray, partly iron-stained, slabbyweathering, laminated to piaty-bedded. soft, friable, very fine grained, subangular to subrounded; lower contact gradational -

Sands tone, medium-gray, oartly iron-stained, mostly obscurely bedded but iaminated to platy-bedded in upper $1.5 \mathrm{ft}$., friabie, ine- to medium-grained (lower i ft.) grading upward to very fine grained (upper 1.5 ft.), subangular to suorounded; lower $3 \mathrm{ft}$. inciudes scattered rourded snaie pebbles (iess than $0.1 \mathrm{ft}$. long) with carbonaceous plant fragments; lower con-

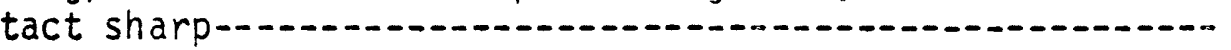

Siltstore, medium-light-gray, partly iron-stained, mostly platy-bedded, hard, tough, clayey; some carbonaceous plant fragments; several very thin iron-rich beds-......- 0.5

Siltstone, medium-gray, jartly iron-stained, obscurely bedded, clayey, mostly sandy; many carbonacecus plant fragments; includes at 0.1 ft.below top a $0.2-f t$. lense of sandstone similar to below; lower contact sharp ard irregular-.............................. 1.1

Sandstone, medium-1ight-gray, mostly iron-stained, obscurely bedded, fricole, very fine to fine-grained, subangular to subrounded; iciver contact sharp-..........-. 1.8 
Siltstone, medium-gray, deep?y iron-stained and hard in upper $0.2 \mathrm{ft}$., obscurely bedded, clayey; many carbonaceous piant fragments; lower contact sharp.............- 1.2

Sandstone, medium-gray, mostly iron-stained, mostly obscurely bedded, friable, very fine grained, subangular

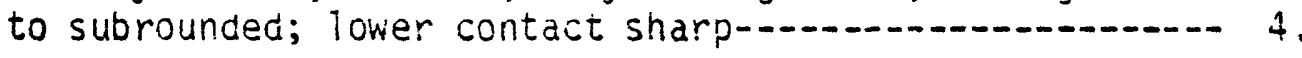

Sandstone, medium-gray, partiy iron-stained, mostiy laminated to platy-bedded, partly friable, very fine grained, subangular to subrounded, silty, very clayey in upper $1 \mathrm{ft}$. ; upper haif inciudes numerous irregular thin (about $0.1 \mathrm{ft}$. ) beds of medium-gray clayey siltstone; ironstone nodules $0.2 \mathrm{ft}$. thick at $1.2 \mathrm{ft}$. below top;

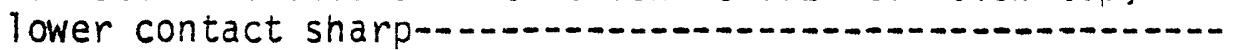

Siltstone, medium-gray, partly iron-stained, slabby-weathering, partly laminated to platy-bedded, obscurely bedded (middle), clayey; some carbonaceous piant fragments, large coalified plart fragments riear dase; includes at $1.5 \mathrm{ft}$. above base a $1.3-\mathrm{ft}$. bed of medium-gray partly iron-stained friable very fine grained subangular to subrounded sandstone and a similar bed of partiy laminated sandstone $0.6 \mathrm{ft}$. thick at $0.9 \mathrm{ft}$. below top; upper $3 \mathrm{ft}$. includes about 4 ironstone-nodule zones

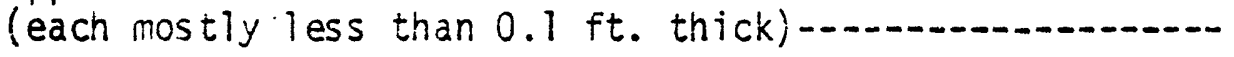

Coal; includes at $0.7 \mathrm{ft}$. above base a $0.5-\mathrm{ft}$. bed of brownish-gray weathered clayey siltstone; lower

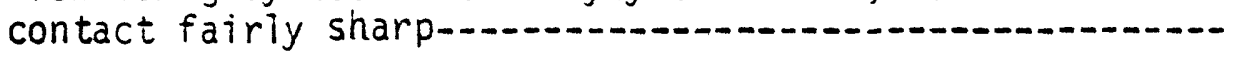

Silts tone, medium-gray, chunky-weathering, obscurely bedded, clayey; many randomly oriented carbonaceous plant fragments; upper $0.1 \mathrm{ft}$. becomes medium-darkgray laminated to piaty-bedded carbonaceous silt-

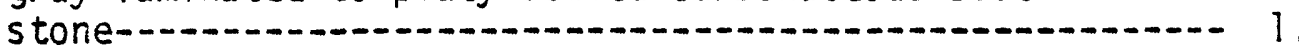

Sandstone, medium-gray, platy- to slabby-weathering, laminated to platy-bedded (lower half), very fine to finegrained, slibanguiar to subrounded, silty, clayey; abundant carbonaceous material near base, numerous large coalified wood fragments at nigh angle to bedding;

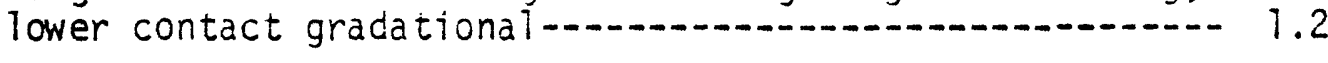

Siltstone, medium-gray, medium-dark-gray (middie), platyweathering, obscurely osdded, sandy in upper $0.2 \mathrm{ft}$, very clayey in lower $0.5 \mathrm{ft}$.; many carbonaceous plait fragments - 
Coal, poor blocky - to piaty-weathering; many flattened coalified logs; inciudes at $0.8 \mathrm{ft}$. above base a lenticular bed (0-0.2 ft.) of brownish-gray fissile- to platy-weathering clayey silitstone with many carbonaceous plant fragments; at $0.3 \mathrm{ft}$. below top lenses (less than

$0.1 \mathrm{ft}$. thick) of medium-brown-weathering siltstone-..... 2.1

Siltstone, medium-gray, light-gray-weathering, obscure platy - to very thin bedded, very clayey; many small and large carbonaceous wood fragments mostly parallel to bedding-..-..-

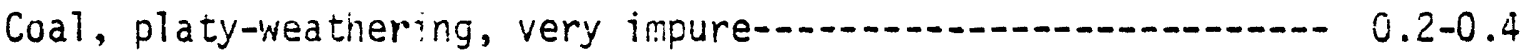

Siltstone, medium-dark-gray, partly iron-stained, laminated to platy-bedded, clayey, very sandy; abundant carbonaceous plant fragments on bedding; lower contact

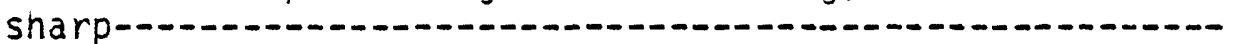

Sandstone, medium-gray, mostly iron-stained, obscurely bedded, friabie, fine-grained, subangular to subrounded, slightly silty; some randomly oriented caroonaceous plant fragments; includes in upper $1 \mathrm{ft}$. very thin irregular beds and lenses of medium-gray to iron-

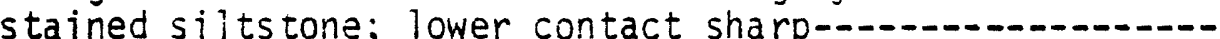

Siltstone and interbedded sandstone; siltstone, mediumgray, chunky-weatnering, obscurely bedded, clayey; many carbonaceous plant fragments; sandstone (lower half of unit), medium-gray, coscurely bedded, friabie, fine- to medium-grained at base becoming very fine grained at top, subanguiar to subrounded, silty; abundant carbonaceous laminations and very thin coal stringers in 0.3-ft. sandstone bed about $3 \mathrm{ft}$. below top of unit; upper $0.5 \mathrm{ft}$. of unit grades to mediumgray partly laminated silty shale; lower contact

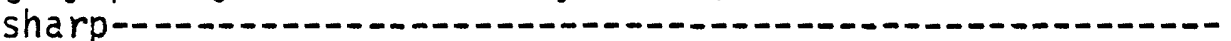

Siltstone, medium-gray, partly iron-stained, mostly obscuroly bedded, some laminated to piaty-bedded, clayey; includes 2 carbonaceous clayey siltstone beds (each about 0.1 ft. thick) at $0.2 \mathrm{ft}$. and about. $8 \mathrm{ft}$. above base; few beds as much as $1 \mathrm{ft}$. thick of medium-gray friable laminated very fine grained silty sandstone; lower contact sharp 
Coal and interbedded siltstone and carbonaceous shäe; coal, mostly platy, one 0.3-it. bed at top, very impure; siltstone, neailin-gray, poor fissile- to piatyweathering, clayey; abundant carbonaceous piant fragments; lower contact fairly sharp--...-...- 0.8

Sandstone, medium-gray, obscurely bedded, friable, finegrained becoming partly very fine grained in upper part, subangular to subrounded, silty; lower contact

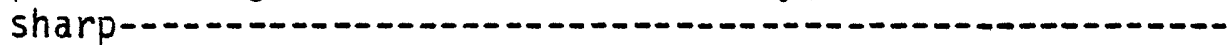

Siltstone, medium-gray, partly iron-stained, mostly obscureiy bedded, sartly laminated to platy-bedded, clayey; few carbonaceous plant fragments; includes laminae and beds (as much as $0.05 \mathrm{ft}$. thick) of very fine grained sandstone in lower part-..-.

Coal, very impure; lower contact sharp--.-.-.-.--

Sandstone, medium-gray, 1 aminated, soft, very fine grained, subangular to subrounded, si ity; grades into siltstone in ueper half; very clayey in upper $1 \mathrm{ft}$. $(8 \mathrm{P}-83)^{*}$; few carbonaceous piant fragments; lower

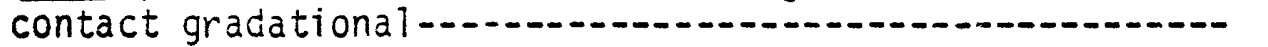

Siltstone, medium-gray, obscurely bedded, clayey; abundant carbonaceous plarit fragments; upper ha if interlaminated with very fine grained silty sands tone; includes 0.1 ft. bed of friabie fine-grained sandstone near middle; $0.1-\mathrm{ft}$. bed of dark-gray coaly shale in upper-middle

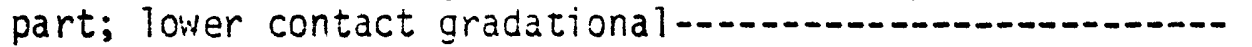

Sandstone, medium-gray, obscurely bedded, friable, fine- to medium-grained (lower $i \mathrm{ft}$.) grading unward to very fine grained (upper $5.5 \mathrm{ft}$.), subangular to subrounded; upper part appears more quartzose than lower part; lower contact sharp and probably disconformable-.........-.

Siltstone, medium-gray, slabby-weathering, obscurely bedded, clayey in upper $0.5 \mathrm{ft}$.; some carbonaceous plant fragments-1.-..-

Coal, impure; flattened coalified logs

Siltstone, medium-gray, poor laminated to platy-bedded, clayey; many carbonaceous plant fragments paraliel to bedding--.-.-.-.-

Coal, very impure-1-1 0.4 
Silts tone, light-brown, 1 ight-gray-weathering, irregular obscurely laminated, clayey, sandy; miany carbonaceous plant fragments; probably of pyroclastic origin-..-...-- 0.1-0.5

Coal, blocky; many flattened coalified logs; lower contact fairly sharp-

Siltstone, medium-gray, obscurely bedded, clayey; some carbonaceous plant fragments; upper part becomes carbonaceous siltstone; lower contact sharp-..............- 1.-1.5

Sandstone, medium-gray, iron-stained, cross-bedded, friable, fine-grained, partly very fine grained (upper part), subangular to subrounded; lower contact sharp and probably disconformabie-.................................. 9

Silts tone, medium-gray, chunky-weathering, obscurely bedded, very clayey; lower contact fairly snür.......... 3.2

Siltstone, brown, dark-gray platy-weathering, obscurely bedded, very clayey; few carbonaceolis plant fragments; upper $0.1 \mathrm{ft}$. includes flat si?tstone clasts; lower

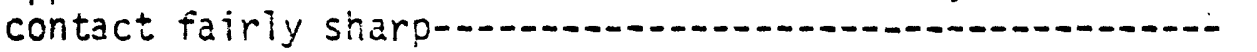

Silts tone, medilum-gray, slabby - to chunky-weathering (poorly observed), obscurely badded, clayey; some small carbonaceous plant fragrents, many large carbonaceous plant fragments norma $i$ to bedding; includes in middle a $1.5-$ $\mathrm{ft}$. bed of laminated to platy-bedied very fine grained subangular to subrounded silty sandstone; grades into shale in upper $i \mathrm{ft}$. $(\underline{8 P-76)} *$; lower contact sharp.......-

Sandstone, medium-gray, iron-stained, laninated to platybedded, friable, very fine grained, subangular to sub-

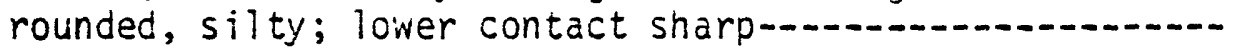

Siltstone, medium-gray, obscurely bedded, clayey, shaiy (upper 1 ft.), friable (lower 0.5 ft.); few carbonaceous plant fragments; lower contact gradational-..... 3.9

Sandstone, medium-gray, iron-stained, obscurely bedded, probably cross-iedded, fine-grained, very fine grained (upper $1 \mathrm{ft.}$ ), very silty (upper $0.5 \mathrm{ft}$. ); includes few platy beds of iron-rich clayey sands tone; lower contact sharp-a. 6

Siltstone, medium-gray, obscurely bedded, friable, soft;

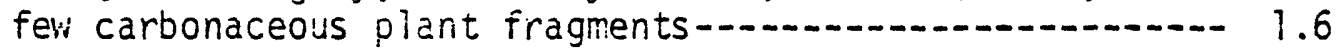

*Palyrological sample 
Ironstone, reddish-brown, clayey; lower contact sharp--.------ 0.1

Siltstone, medium-gray, obscurely bedded, clayey; few carbonaceous plant fragments; lower contact gradational-.-.-.- $2 . \hat{0}$

Sandstone, medium-gray, partly iron-stained, mostly iaminated to platy-bedded, partly obscurely bedded, very fine grained, subangular to subrounded; inciudes at $7.5 \mathrm{ft}$. above base a 1.5-ft. bed of medium-gray iron-stained friable fine-grained clayey sandstone (contacts sharp at base and gradational at top); at $12 \mathrm{ft}$. above base a 2.5-ft. bed of medium-gray obscurely bedded clayey siltstone with carbonaceous

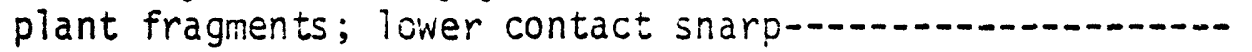

18.

Sandstone and interbedded siltstone; sandstone, medium-gray, partly iron-stained, laminated to platy-bedded (oartly obscure), partly friable, very fine grained, subangular to subrounced; forils beds mostly 2-4 ft. thick; includes 3 friable fine-grained sandstone beds, each about $0.5 \mathrm{ft}$. thick; siltstone, medium-gray, cbscurely bedded, clayey; some carbonaceous piant fraginents; forms beds about $0.5 \mathrm{ft}$. thick except for $1.5-\mathrm{Tt}$. bed at base and a $3-\mathrm{ft}$. bed about $12 \mathrm{ft}$. above base; siltstone in upper $5 \mathrm{ft}$. includes clayey ironstone nodules as much as $0.2 \mathrm{ft}$. thick; lower contact

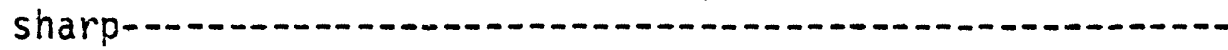

Sandstone, medium-gray, iron-stained, mostiy laminated to platy-bedded, fine-grained (basal $1 \mathrm{ft}$.) to very fine grained, subanguiar to subrounded. very silty (upper $2 \mathrm{ft.}$ ); some Taminae of very fine carbunaceous material; some iron-rich beds as much as $0.05 \mathrm{ft}$. thick mostly in upper half; lower contact sharp-..............-.

Sandstone, medium-gray, partly laminated to platy-bedded, friable, very fine grained, subanguiar to subrounded, very silty; includes at $1 \mathrm{ft}$. acove base a 0.5-ft. bed of friable fine-grained sanastone; upper half becomes partly iron-stained clayey siltstone; few large coalified wood fragments; lower contact fairly sharp--.-.-

Shate $(\underline{8 P-68})^{*}$, medium-gray, obscureiy bedded; includes medium size sand grains (probasiy of volcanic origin); few smali carbonaceous plant fragments 
Coal and interbedded siltstone and carbonaceous shale (lenticular beds as wuch as 0.5 it. thick); coal, platy-weathering; flattened coalified logs; siltstone, medium-gray to brownish-gray, obscurely bedded, clayey; some carbonaceolis oiant fragments and large coalified wood fragments; abundant. white angular grains (volcanic

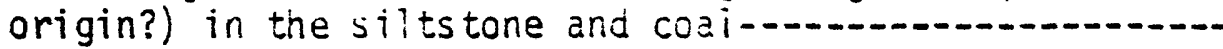

Siltstone, medium- to medium-dark-gray, obscurely bedded, clayey; very carbonaceous in basal $0.5 \mathrm{ft}$.; many carbonaceous plant fragments; many large plant fragments in upper 1 it.; lower contact gradational-......... 4.4

Sandstone, medium-gray, mostly cbscurely bedded, laminated to platy-bedued (at 9.5-12 ft. above base), mostly friab?e, fine- to medium-grained (basai 1.5 ft.) grading upward to very fine grained and very silty (upper $4 \mathrm{i \tau}$.), subangular to angular; fine carbonaceous material and much iron stain at 9.5-12

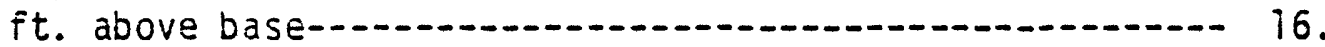

Coai 0.6

Siltstone, medium-gray, clayey; carbonaceous plant frag-

ments--_-_-_.

Coal; includes 0.1 -ft. bed of dark-gray carbonaceous

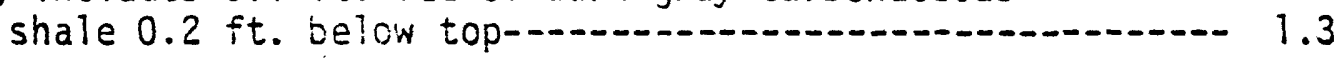

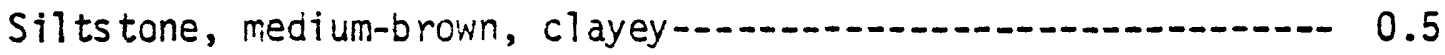

Coal; much medium- to dark-gray carbonaceous shale in basal $0.3 \mathrm{ft}$.; includes $0.1-\mathrm{ft}$. ienticular bed of

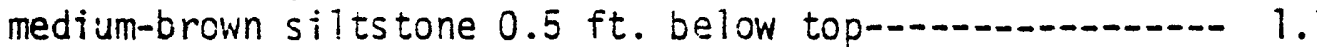

Siltstone, medium-gray, obscureiy bedded, clayey; many

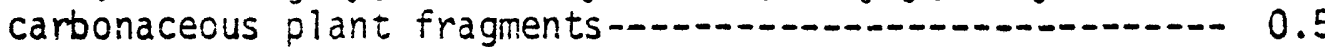

Coal; includes $0.2-\mathrm{ft}$. bed of dark-gray very carbonaceous shale in middle-1..... 0.8

Sandstone, medium-gray, partly iron-stzined, obscurely bedded, probably partiy cross-bedded, friable, fineto medium-grained (basal part) grading upward to very fine grained and very silty (upcermost part), subangular to subrounded; lower contact sharp-......-.-.-- 11.3 
Siltstone, medilim- to medium-dark-gray, mostly obscure platy-bedded, clayey, sandy in basal part; many carbonaceous plant fragments in part; lower contact

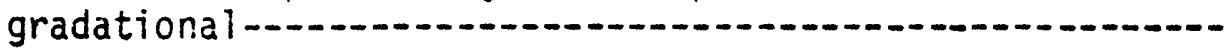

Sandstone, medium-gray, partly iron-stained, slabbyweathering, partiy laminated to platy-bedded, friable, fine-grained, fine- to medium-grained (basal $1 \mathrm{ft}$.); subangular to subrounded, upper $0.5 \mathrm{ft}$. grades to micaceous clayey siltstone; many randomily oriented carbonaceous piant fragments in upper $1.5 \mathrm{ft}$.; lower

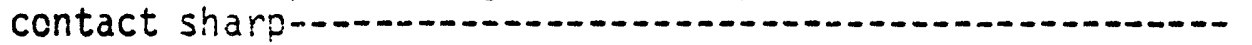

Sandstone, medium-gray, poor platy- to poor slabby-weathering, obscurely beaded, partly friable, very fine to fine-grained, medium- to coarse-grained basal 1.5 ft.); subanguiar to subrounded, silty; includes few medium-gray sandy clayey silts tone beds about 0.5

$\mathrm{ft}$. thick in middie and upper parts

Coal and carboraceous shale (subequal amounts); coal, impure; mostly in lower nalf of unit; poorly exposed--.-

Siltstone, medium-gray, light-brown tinted, obscurely bedded, clayey; white anguiar grains (volcanic

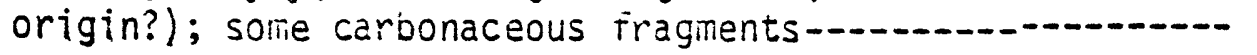

Coai; includes irreguiar partings of medium-gray siltstone in lower half and brown siltstone (pyroclastic?) less than $0.1 \mathrm{ft}$. thick about $0.2 \mathrm{ft}$. below top-........- 0.7

Siltstone, medium-gray, partly brcivn tinted, obscurely bedded, clayey; abundant caroonaceous piant fragments, some large fiattened coalified logs; inciudes very irregular coal lenses as much as $0.5 \mathrm{ft}$. thick near

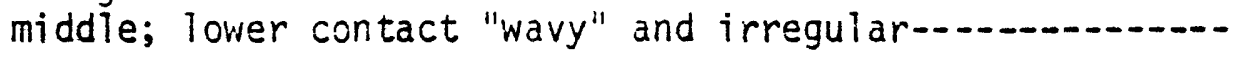

Coal, platy- to blocky-weathering; includes a 0.2-ft. bed of brownish-gray carbonaceous shale at base and ienticular bed of medium-brown siltstone about 0.1-0.2 $\mathrm{ft}$. thick at $0.2 \mathrm{ft}$. below top-a 1.3

Silts tone, medium-gray, obscurely bedded, very clayey; many randomiy oriented carbonaceous plant fragments; includes at top 0.5-ft. bed of medium-gray non-bedded claystone $(8 \mathrm{P}-59)$ * (underclay?) with abundant plant

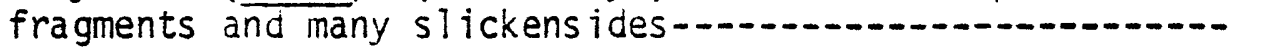


Sandstone, medium-gray, partly iron-stained, obscurely bedded, iriable, fine-grained to very fine grained at top, subariguiar to subrcunded; lower cortact fairly

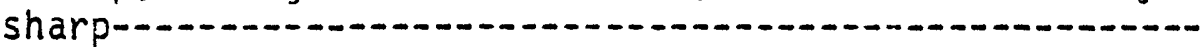

Siltstone, medium-gray, partly iron-stained, chunky- to poor slabby-weathering, osscurely bedded, hard, very clayey; some carbonaceous plant fragments; lower con-

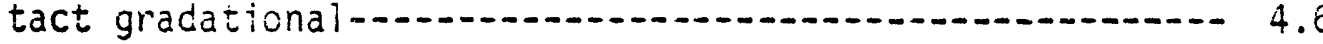

Shale (8P-58)*, dark-gray (base) to medium-gray (top), cbscurely bedided; abundant carbonaceous plant fragments; iower concact gradational-.......................... 0.7

Coal, very impure; lower contact snarp.......................... 0.3

Sandstone, medium-gray, most?y iron-stained, partly irregular laminated to platy-bedded, mostly friable, very fine grained, subangular to subrounded, silty, clayey; few ironstone nodules iess than 0.1 ft. thick about 3 ft. above base; some carocnaceous piant fragments in upper-middle part; inclides medium-gray obscurely bedded ciayey siltstone in basal part $(1.5 \mathrm{ft}$.$) and$ in beds about $1 \mathrm{ft}$. thick in upper $4 \mathrm{ft}$.; lower contact sharp-1.-11.

Sandstone and interbedded siltstone (subequal amounts); sandstone, redium-gray, mostiy laminated to piatybedded, parr?y friable, very fine grained, subanguiar to subrounded; abundant fine carbonaceous material on many bedding planes; forms beas about $1-2 \mathrm{ft}$. thick; siltstone, redium-gray, obscure to poor platy-bedded, very clayey; many carbonaceous plant fragments; unit includes few beds about $0.5 \mathrm{ft}$. thick of medium-gray silty shaie with plant fragments; 0.3-ft. bed of darkgray carbonaceous silts tone at top; lower contact sharp--.-

Sandstone, medium-gray, partly reddish-brown stained (caused by burning of underlying coal?), obscureiy bedded, very fine grained, subangular to subrounded,

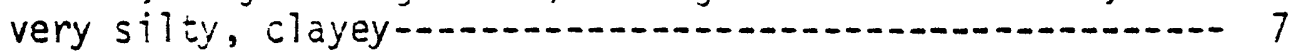

Coal bloom, Bed U (?), deeply weathered, clayey; inciudes at top yelicivish-brown and reddish-brown ccal ash

$0.1 \mathrm{ft}$. thick- 
Siltstone, medium-gray, upper part stained reddish-orown (result of burning of overiying coal?), obscurely bedded, clayey in basai 0.2 ft.; iowar half includes numerous thin beas of iaminated to piaty-bedded very fire grained subangular to subrounded sandstone; lover contact fairly snarp

Sandstone, medium-gray, partly iron-stained, poor piatyweathering, iaminated to platy-bedded, partiy friable, very fine grained, subangular to subrounded, mostly silty; includes at base a $0.5-f t$. bed of friable fine-grained sarastone and a similar bed about $5 \mathrm{ft}$. above base; latzer sed overlain in upward order by hard micaceous very sandy siitstone acout $2 \mathrm{ft}$. thick and very clayey siltstone about $0.5 \mathrm{ft}$. thick;

lower contact sharp-a.

Siltstone, medium-gray, slabby-weathering, obscure platybedded, clayey, very sandy; few carbonaceous plant fragments; inclucies at base a bed of platy-weathering mediumi-dark-giay clayey siltstone about $2.5 \mathrm{ft}$. thick; near midaie a few beds of medium-gray very fine grained very silty clayey sandstone with average thickness of about i ft_...

Coal, Bed T (?), platy- to blocky-weathering, impure; many flattened coaifified logs in upper haif; includes near middle a 0.1-ft. Tenticular bed of mediunl-gray clayey

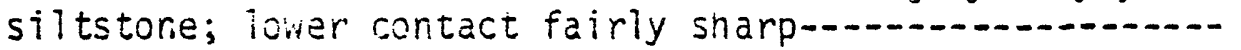

Shale $(8 P-51) *$, medium-dark-gray, poor fissile-bedded, sitity; abundant caroonaceous plant fragments mostiy on bedding; localiy includes 0.2-ft. coal at base;

lower contact fairly sharp-....... 1.6

Siltstone, medium-gray, partly iron-stained, localiy slabby-weathering, abscurely bedded, hard in basal

1 ft., very clayey; scattered randomly oriented carbonaceous olant fragrents; ironstone nodules in basal $1 \mathrm{ft}$, near middle, and in upper $0.2 \mathrm{ft}$. ; lower contact fairly sharp-a.

Sandstone, medium-gray, iron-stained, laminated to platybedded, friable, very fine grained, subangular to subrounded, clayey, very silty in lipper $2 \mathrm{ft}$; lower contact gradational

Sandstone, medium-gray, obscurely bedded, friable, finegrained, subangular to subrounded; lower contact gradational 
Sandstone, medium-gray, iron-stained, poor platy-weathering, laminated to platy-bedded, friable, very fine grained, subangular to subrounded, silty, ciayey; hard iron-rich bed $0.1 \mathrm{ft}$. thick $0.3 \mathrm{ft}$. above base; lower contact

fairly sharp-........ 1.5

Sandstone, medium-gray, mostly iron-stained, massive-

weathering, poor cliff-forming, lamirated to platy-bedded, cross-bedced (cross-bed sets about $1.5 \mathrm{ft}$, thick), partly friable, fine-grained, suoangular to subrounded;

few iron-rich lenses as much as $0.5 \mathrm{ft}$. thick about 8-12 ft. above base; few ironstone nodules at is ft. above base and probably at other places; lover contact sharp

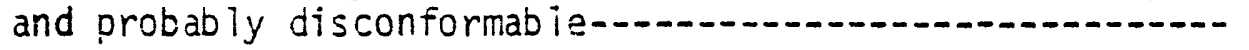

Shale, medium-gray, obscurely bedded; many carbonaceous plant fragments; abundant coa! ified wood iragments in $0.1-\mathrm{ft}$. zone $0.5 \mathrm{ft}$. above base; lower contact sharp-.... 3.4

Coal, platy-weathering, very impure; lower contact fairly sharp---

Siltstone, medium-gray, obscurely bedded, clayey; abundant randomiy oriented carbonaceous plant fragments; lower contact fairly sharp-1.

Coal, platy-weathering, very impure; lower contact gradationai--

Siltstone, medium- to medium-dark-gray, partly iron-stained, poor platy- to chunky-weathering, partly laminated, partiy carbonaceous, clayey; abundant carbonaceous plant and wood fragments; iower contact sharp-...-...-.-- 2.9

Siltstone, inedium-gray, slabby-weathering, probably laminated to platy-bedded (obscure), clayey; abundant carbonaceous plant fragments (roots?) in part, some leaf impressions; grades into medium-gray obscurely bedded friable very fine grained subanguiar to sub-

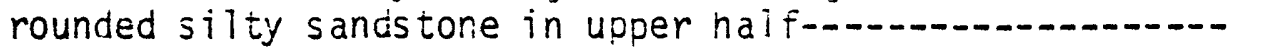

Coal, Bed S (?), platy - to massive-weathering, cartly very impure; many flattened coalified logs; inciudes 0.1ft. lenticular bed of brownish-gray sandy carbonaceous siltstone $0.1 \mathrm{ft}$. below top; lower contact sharp-......-- 
Sandstone and interbedded siltstone, mostiy similar to below; many carbonaceous olant fragments and large randomly oriented coalified wood fragments; incluaes at base bed of medium-gray friable fine- to medilimi-grained subangular to subrounded silty sandstone about $i .5 \mathrm{ft}$. thick and at top bed of very fine grained sandstone about $2 \mathrm{ft}$.

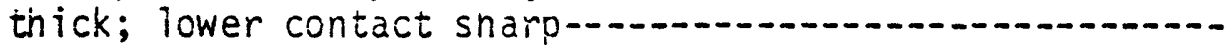

Sandstone and interbedded siitstone; sandstone, medium-gray, much iron-stained, partiy laminated, mostiy triabie, very fine grained, subanguiar to subrounded; includes at $8.8 \mathrm{ft}$. above base a $0.3-\mathrm{ft}$. ted of medium-gray iron-stained hard sanay clayey siltstone overiain by 1.3-ft. bed of brownish-gray siltstone; 0.5-it. bed of medium-gray silty shale at top; some carbonaceous plant fragments in siltstone and shale; beds in unit commoniy $1-2 \mathrm{ft}$. thick; lower

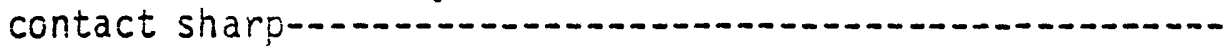

Siltstone, medium-gray, obscurely bedded, clayey, partly sandy; some carbonaceous plant fragments randomly oriented in part-a.

Coal; locally sharp variation in thickness; lower contact sharp--

Siltstone and interbedoed sandstone, slabby - to chunkyweathering; siltstone, medium-gray, ooscureiy bedded, clayey; abundant carbonaceous plant fragments in part; sandstone, medium-gray, partly laminated, friable, very fine grained, subangular to subrounded; $1.5-\mathrm{ft}$. sandstone bed at top includes large randomly oriented

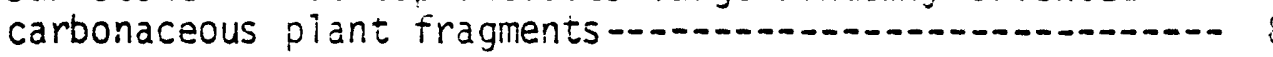

Siltstone, light-gray to yellowish-gray, sandy; may be a

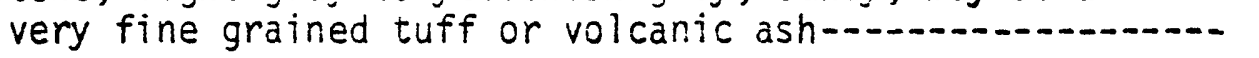

Siltstone, dark-gray, carbonaceous, clayey-_.................... 0.3

Coal, impure-1 0.4

Shale $(\underline{8 P-39}) *$, medium-dark-gray, poor platy-bedded; abundant carbonaceous plant fragments and coal stringers mostly parallel to bedding; lower contact gradational-......-.-- 1.6

Siltstone, yellowish-gray, partiy laminated, clavey; few carbonaceous plant fragments; may be a very fine grained tuff or volcanic ash 
Siltstone, medium-gray, partly iron-stained, cbscure platy-bedded, clayey; many carbonaceous piant fragments in part; inciudes iew beds as much as i ft. thick of medium-gray partly laminated to platy-beaded very fine grained sandstone; lower contact fairly sharp-....-. 13.

Sandstone, medium-gray, partly iron-stained; partly faint platy-bedded, friabie, fine-grained, subangular to subrounded; very fine grairied and partiy iaminated in upper $3 \mathrm{ft}$. ; abundant carbonaceous plant fragments in 0.i-ft. zone $4.3 \mathrm{ft}$. above base; lower contact sharp--.-.-. 10

Siltstone, similar to below, partiy mcttled; includes

light-gray deeply weathered irregular coarse clayey grains (volcanic origin?) in $0.1-0.2-\mathrm{ft}$. beds about $5 \mathrm{ft}$. above base and in upper part; few interbeds of sandstone similar to beiow-.............................. 13

Siltstone, medium-gray, slabby- to poor platy-weathering, partly iaminated to obscure platy-bedded, ciayey; carbonaceous plant fragments scattered to abundant; includes several beds, about $1 \mathrm{ft}$. thick, of mediumgray very fine grained sandstone; lower contact sharp;

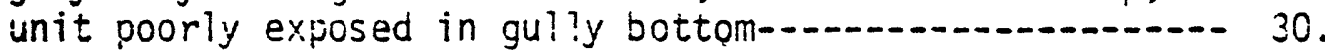

Siltstone (volcanic ash?), medium-light-gray, obscurely bedded, soft, clayey-1...

Siltstone, mostly medium-1ight-gray, brownish-gray (upper $1.5 \mathrm{ft}$.$) , partly slabby - to poor platy-weathering,$ obscure platy-bedded, clayey; many carbonaceous fragments in part (some randomily oriented); includes near middle a bed, about $2 \mathrm{ft}$. thick, of medilumgray partly iron-stained laminated very fine grained sandstone; lower contact gradational; unit miostly covered-

Siltstone, medium- to dark-gray, obscurely bedded, clayey; some carbcnaceous plant fragments; includes in middle a bed, about $0.5 \mathrm{ft}$. thick, of medium-gray very fine grained sandstone; lower contact sharp-..................... 1.5

Shale, dark-gray, poor fissile to claty-bedded, carbonaceous; abundant plant fragments-......................... 0.2

Coal, mostly platy - to partly blocky-weathering; lower

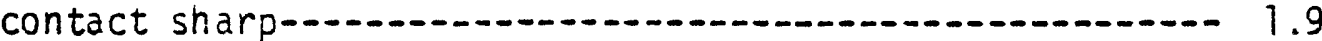


Silts tone $(\underline{\varepsilon P-32}) *$, medium-dark-gray, partly brown tinted, poorly fissi ie to piaty-becded, hard, clayey; abundant carbonaceous plant fragments; lower contact sharp--.-.-.-- 0.9

Siltstone and interbedded sandstone; siltstone, mediumgray, poor zaty-weathering. clayey; abundant carbonaceous jian fragments in 0.2-ft. zone 2 it. below top; sancs tone, generaily similar to below; beds as much as $2+t$. thick; incluces a $0.1-\mathrm{ft}$. coai bed at $20 \mathrm{ft}$. above base; unit mostly covered except in

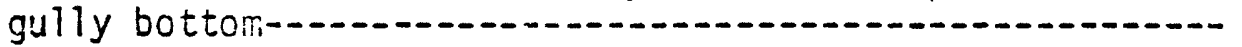

28.

Sandstone, medilim-gray, partiy iron-stained, poor platyweathering, iaminated to placy-bedded, partly crossbedded, very iine grained, partly very silty, clayey; many carbonaceous iaminations in part; includes a few siltstore bods similar to zbove and as much as i $\mathrm{ft}$. thick; medium-dark-gray carconaceous siliszone oeds (0.1-0.2 ft. thick) at about j, 10, and $12 \mathrm{ft}$. above base; siltstcne bed at $5 \mathrm{ft}$. above base incluces $0.05-f t$. bed oi ? ight-gray asn in middie; few ironstone noduies at i7 ft. above base; urit mostiy

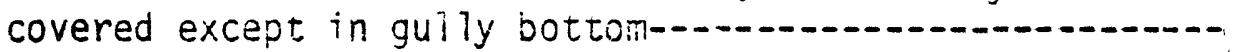

20.

Coal (locally burned), platy - to blocky-weathering, impure in upper $0.7 \mathrm{ft.;}$; many flattened coalified logs-...........

Siltstone, redium-gray, poor platy-bedded, clayey, finely sandy; many caroonaceous ziant fragments in some beds (locally oxidized to redaish-brown color near top of unit); inciudes near base 2 beds of carbonaceous shale (baked red iocally) about 0.1 it. thick; 2 beds of medium-gray friable very fire grained slicanguiar to subrounded sandstone each about $0.5 \mathrm{ft}$. inick near

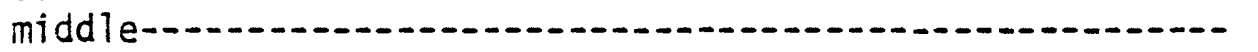

Shale, dark-gray, fissile, carbonaceous-........................ 0.5

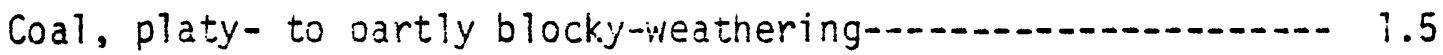

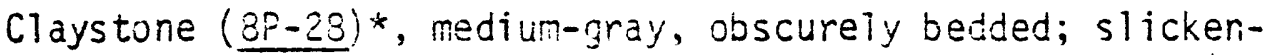
sides; abundant carbonaceous plant irägrents--.-.-.--.-- 0.2-0.5

Shale, dark-gray, fissile to platy-bedded, carbonaceous;

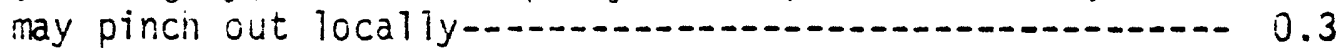


Sandstone and interbedded siicstcne; sardstone, medium-

gray, localiy iron-stained, propapiy platy-iedded

(obscure), friabie, very fine to irre-grained, suo-

angular to subrounced; average bod thickness abodi

3 ft.; beds become finer grained joward and grace

into siltstore: siltstone, mealiri-gray, partly iron-

stained, obscuioly jodded, ciayey, fineiy sandy;

beds about $?$ ft. trick and poor ledge formers iocaliy;

few carbonaceous plant fragments; few large coalified

logs in upper part of unit; iower contact sharo-...... 14.4

Sandstone and inzertecded siltstone; sancstone, medium-

gray, laminated, oartiy triable, very fine grained.

subangular to sucrounded, silty; iverage bed thickness

about 2.5 ft.; silistone, nedium-gray, obscurely

bedded, hard, ciayay; abundant caroonaceous piant

fragments in part; lower contact snarp-... 10.4

Sandstore and interbedded siltstore; sandstcne, medium-

gray, locally iron-stained, propaciy platy-bedded

(obscure), friabie, very fine to ine-grained, sixo-

angular to subrounded; average ced inickness about 3

ft.; beds become finer grained uplvard and grade into

siltstone; siltstone, medium-gray, soscurely bedied,

clayey; beds about $i \mathrm{ft}$. thick and poor ledge formers

locally; few carboraceous plaric fracrents; lower

contact gradational; apparentiy graces into massive

sandstone on east side of gully-

20.7

Siltstone and interbedded sandstone; siltstone, mediumgray, mostly poor platy-and scme nackly-weathering, obscure platy-beoded, clayey; asundant carbonaceous

plant fragments in sart; sancs tone, medium-gray, partiy laminated, very fine grained, subangular to subrounded; beds about 1 ft, tnick; 1 bed about 3.5 ft. thick of friable sandstore $n$ ear middle-_......... 3.6

Coal, platy-weathering, very imoure; includes in middle a $0.2-f t$. lenticular bed of medium-i ignt-gray hacklyweathering obscurei, bedided cia igy silitstone with

many carbonaceous clant fragments-..

Siltstone $(\underline{Q P-23})^{*}$, as above-1. 0.3

Coal, platy-weathering; lower $0.3 \mathrm{ft}$. grades into carbonaceous shale; iower contact sharp-a. 0.8 
Siltstone, medium-1ight-gray, chunky-weathering, obscurely bedded, hard, clayev, micacecus; abundant carbonaceous plant iragments (roots?); upper $0.4 \mathrm{ft}$. becomes i ignt-brownisn-gray and poor piaty jeddec-...-...- 4.

Siltstone, medium-gray, obscurely bedded (lower $5.5 \mathrm{ft}$. ) and laminaced to platy-bedded (uppei 6.3 ft.), clayey; some randcmiy oriented carboraceous piant fragments; includes several sandstone beds as much as j.5 ft. thick in upper $6.3 \mathrm{ft}$. and at top a bed of yery fine grained sancs tone about $2 \mathrm{ft}$. thick; white stringer composed of plagioclase and quartz grains at about $1.5 \mathrm{ft}$. below top; iower contact sharp--..-- 11.8

Siltstone, medium-gray, poor platy-weathering, laminated to platy-zedded, clayey: some carbonaceous jiant fragments; inciudes severai beds, abcut $0.5 \mathrm{ft}$. thick, of friable very fine to fine-grained subanguiar to subrounded sandstone; $1.8-\mathrm{ft}$. bed of sandstone at top--

Coal; Bed $R$ (?), includes $0.1-f t$. bed of hard brownish-gray

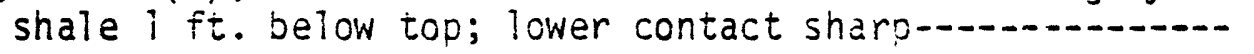

Siltstone, medium-gray, partily iron-staired, hacklyweathering, ooscurely bedded, clayey; many randomiy oriented smail and large caroonaceous piant fragments; includes a $0.5-f t$. bed of very fine grained friable subangular to subrounded sandstone about i.5 ft. below top; iower contact gradationai

Sandstore, medium-gray, mostiy iron-stained, slabby-weathering, obscure platy-bedded, cross-bedded, friable, fine- to medium-grained (lower part) grading upward to very fine grained (upper third), sibangular to suorounded; basai $1 \mathrm{ft}$. inciudes irreguiar ienses of medium- to coarsegrained sariastone, clasts of ironstone and dark-gray hard shaie, and local iron-rich lenses; scattered large coa? ified wood fragments; lo'ver contact sharp, disconformabie, and locally channeled into underlying rocks as much as $3 \mathrm{ft}, \ldots$

Sandstone and interbedded siltstone; sandstone, medium-gray, partly iron-stained, ooscure platy-bedded, friable, very fine to fine-grained, subangular to sucrouraed; siltstone, medium-gray, partly iron-stained, platy-bedied, clayey; some carbonaceous plant framents in both rock types; upper $11.7 \mathrm{ft}$. of unit probably more than half siltstone; includes at $11.3 \mathrm{ft}$. above case a $1.3-\mathrm{it}$. bed of mediumgray silty shaie ( $Q P-10)$ * with many randomly oriented

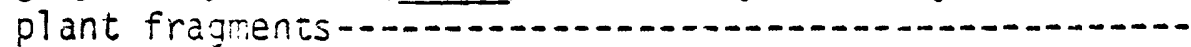


Siltstone, mediumi-gray, partiy iron-stained, poor platyweathering, lamnated to platy-bedded, clayey; some carbonaceous plant fragmenis; lower contact

gradational-...-...

Siltstone, medium-dark-gray to brownish-gray, piaty-bedded, clayey; abundant carbonaceous piant fragments; includes at base a 0.5-ft. Ded of mediun-gray silty sinale with many plant fragments; very thin coal stringers abcut

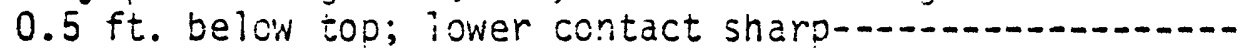

Sandstone, madium-gray, obscurely bedded, friable, finegrained, subanguiar to subrounded; locally inciudes 0.2-ft. cartonaceous zone about? ft. below top; lower contact sharp-1..-

Siltstone, medium-gray, brownish-gray (iniddle), chunkyto hackly-weathering, obscure very thin to thinbedded, clayey; many randomiy oriented carbonaceous

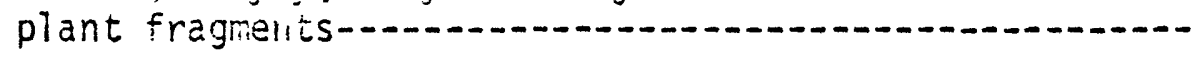

Sancistone, medium-gray, prodably poor platy-weathering, laminated to platy-bedded, very fine grained, subangular to subrounded; scattered carbonaceous plant fragments; lower half includes fely seds, adout 0.5 ft. thick, of fine-grained sandstone-_-_.................. 17.8

Covered interval; probably silty shale in lower half-......... 6.7

Coal(?), deeply weathered-1...

Shale, light- to redium-brown, deeply weatnered; aopears bentonitic-

Shaie, dark-gray, poor platy-bedded; abundant large carbonaceous plant fragments in lower part; some coal stringers in upper part; inciudes $0.5-f t$. platy-

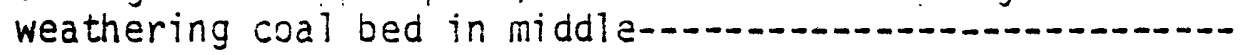

Coal, platy-weathering; upver $0.3 \mathrm{ft}$. orobably very impure with many flattened coalified logs; inciudes at 2.3 ft. above base a 0.i-ft. sorrewhat lenticular bed of light-brown clayey s 1 ts tone (fire-grained tuff?) with abundant carbonaceous plant iragments; lower

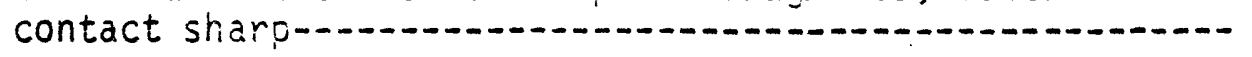


Siltstone, medium-gray, obscure platy-bedded, ciayey; few carbonaceolis plant fragments; includes $1-f t$. bed of medium-gray laminated very fine grained sandstone 0.5

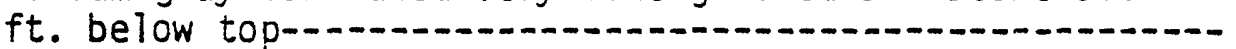

Sandstone, medium-gray, obscure laminated to platy-bedded, friable, very fine grainea, subangu!ar to subrounced, silty; inciudes silitstone interbeds and becomes mostiy siltstone in ipper half; lower contact sharp-............. 5.

Sandstone, medium-light-gray, partly iron-stained, massiveweathering, platy-bedded, much cross-bedied (crossbed sets about 1 it. thick), friable, fine- to mediurigrained (lower $6 \mathrm{ft}$.) becoming fine-grained upwara, subangular to subrounded; some very caroonaceous laminations; includes near base coárseiy sandy ciayey lenses as much as $0.2 \mathrm{ft}$. thick; near niddle a very iron-rich zor.e about $2 \mathrm{ft}$. thick with resistant ledges as much as $0.3 \mathrm{ft}$. thick-_... 31.7

Coal, Bed Q (?), platy-weathering in basal $0.2 \mathrm{ft}$. and upper $0.5 \mathrm{ft} .-1.5$

Sandstone, medium-gray, slabby-weathering, platy-bedded, partiy laminaied, cross-bedded, friable, finegrained, subangular to subrounded, slightly silty; some very fine grained caroonaceous 1 aminae; some ironstone clasts as much as $0.15 \mathrm{ft}$. thick; felw large coalified wood fragments in lower part; includes several sandy clayey siltstone beds as much as $3 \mathrm{ft}$. thick; upper $4 \mathrm{ft}$. becomes siltstone ( $8 \mathrm{P}-9$-- about 3 $\mathrm{ft}$. below top)* with abundant randomly oriented caroonaceous plant fragments and some roots(?) that extend downward about $1 \mathrm{ft}$. from the overlying coal; lower contact sharp; mostly not well observed because of very steep hillside-...

Siltstone and interbedded shale, medium-gray, hackly- to poor platy-weathering, laminated to platy-bedded; abundant carbonaceous plant fragments in shale;

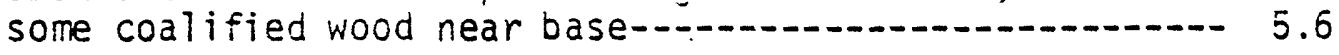

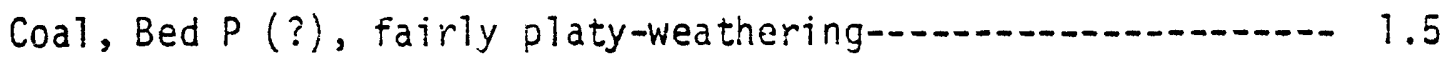

Shale, dark-gray, caroonaceous; lower contact sharp-_-_-_-_--.- 0.5 Shale, medium-gray, silty; many carbonaceous plant fragments--.-- 
Sandstone, medium-gray, poor platy-weathering, laminated (lower $1 \mathrm{ft.}$ ), very fine grainea, subançular to subrounded, slightly clayey; lower contace sharp-..-.-...-.- 1.3

Sandstone, medium-aray, partiy iron-stained, partly slabbyweathering, obscurely jedded, friable, very fine to fire-grained, sibangular to subrounced; iower contact

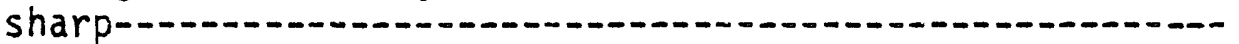

Siltstone, medilu-gray, piaty-weathering, poor piaty-bedded, clayey; scattered ironstone nodules as much as $0.2 \mathrm{ft}$. thick; sore interlaminations of sandy silitstone and carbonaceous plant material; inciudes noar middle a $0.5-f t$. bed of black fissile carbonaceous shale;

lower contact sharp-a.-...- 7.8

Sandstone, recium-gray, locally slightly iron-stained, partly slabby-wezthering, obscurely bedied, very friable, very fine to fire-grained, angular to subanguiar; lower contact sharp--.-.-.-. 5.4

Siltstone, medium-gray, hackiy-weathering, obscurely bedded, very clayey; abundant carbonaceous plant fragments, feiv large coalified logs; upper $0.2 \mathrm{ft}$. becomes platy weathering and carbonaceous; lower contact sharp--.-.-.-.-.

Coal, lower 3.8 ft. hard; large coalified tree stumps locally; upper $1.5 \mathrm{ft}$. platy weathering with many flattened coalified logs; includes at $0.4 \mathrm{ft}$. below top a 0.3-0.7-ft. Ded of medium-gray claystone $(8 \mathrm{P}-4) *$ with abundant cartonaceous piant fragments; lower contact sharp; forms about 10-ft. waterfall-.....-. 5.3

Siltstone $(\varepsilon P-3)^{*}$, medium-gray, non-bedded, very clayey; abundant carbonaceolis piant fragmenis-................... 0.4

Sandstone, redium-gray, partiy iron-stained, poor slabbyweathering, laminated, yery fine to fine-grained, silty, clayey; some small and iarge cartonaceous plant frag-

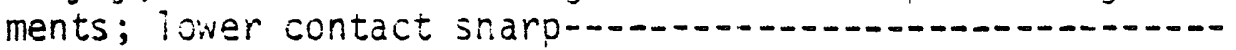

Siltstone, medium-gray, chunky-weathering, partiy poor platybedded, fairly hard, clayey; ironstone rocules as miucr as $0.3 \mathrm{ft}$. thick about $2.5 \mathrm{ft}$. above base; abundant carsonaceous plant fragments on bedding and randomly oriented; includes very fine grained sandstone laminae and, at 3.3 $\mathrm{ft}$. above base, a sed $0.8 \mathrm{ft}$. thick of medium-gray friable very fine grained sandstone; lower contact sharp-........ 7.8 
Sandstone, medium-gray, mostiy iron-stained, mostly obscurely bedded, some platy-badced (upder ? tt. ), probably crossbedded, friable, fine- co mecium-gräned becoming mostiy fine-grained in upper $5 \mathrm{ft}$., subangular to subrounded;

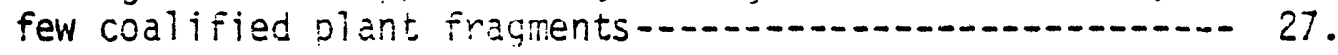

Covered interval-1-2. 6

Coal, Bed O(?), exposed in creek bed abrut 30 yi. downstream from sancistone described above; base conceaied--.- 1.8+ 


\section{Measured section 9}

Location: Hillside exposure in small open caryon on west side of Fox Creek in SE 1/4 iE 1/4 See. 5, T. + S., R. $10 \mathrm{~W}$., Seidovia D-3 quadrangle. Measured section is about $300 \mathrm{ft}$. above Fox Creek.

Feet

Tertiary rocks -- Kenai Group, Stering Formation

Upper part of exposed rocks not measured

Sardstone, medium-gray, oartiy ircn-stained, locally cliff-

forming, lamirated to piaty-bedded, cross-iedded, fine-

to medium-grained, becomes irne-grained upward; Fev

coarse grains in basal 1 ft.; Buer half samoled and

remainder estimated; Tower contact snarp and probabiy

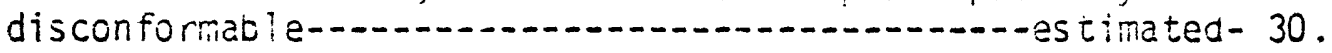

Siltstone, medium-gray, hackiy-weatnering, obscurely bedded, very clayey; some carboraceous piant iragments-...........- 1 .

Coal, impure; inciudes a 0.1-ft. lenticular bed of finegrained tuff $f$

Siltstone $(99-13)^{*}$, medium-gray, hackiy-wea thering, obsclirely bedded, clayey; some iarge coal ified irood fragnients.....-- 1.6

Coal- 0.5

Tuff, light-yellowish-brown, white-weathering, coarse-

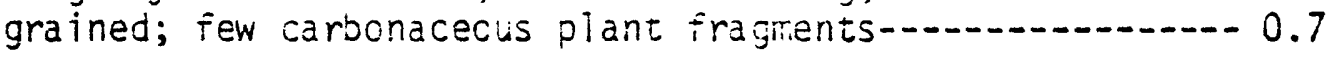

Coal and interbedded silts tone; coal beds average about 0.3 $\mathrm{ft}$. thick; siitstore, retium-gray, coscurely bedied, clayey; abundant carbonaceous diant fragments; beds average about 0.2 it. thick; lower contact sharp-.-.-.-.-. 2.3

Sandstone, medium-gray, orobably iaminated to platy-bedced and cross-becded (osscure), fine-grained, subangular, slightly clayey; incluces $0.2-\mathrm{ft}$, beds of medium-gray siltstone at base and about $3.5 \mathrm{ft}$. below too; udoer 1 $\mathrm{ft}$. becomes silistone; very carbonaceous in upper 0.1

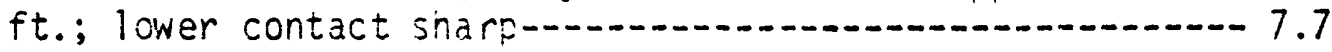

Siltstone, medium-dark-gray, poor platy-oedded, clayey; abundant carboraceous plant fragments and large flattened coalified logs -........ 0.8 
Coal, impure; lower contact sharp-a- 1.3

Siltstone, medium-gray, sbscureiy bedded, clayey; few carbonaceous plant iragments; inciudes at $0.2 \mathrm{ft}$. above base a 1.5-ft. bed of ooscurely sedded friable very fine to fine-grained sandstone that Decomes riner upward-.........- 5.2

Coal, very impure: lower contact sharp-......................-. 0.2

Siltstone, medium-gray, partly iron-stained, obscurely bedded, clayey; few carconaceous piant fragments-.........- 5.

Sandstone, medium-gray, friable, very fine to medium-grained, subangular; becomes finer grained ulward; lower cor.tact sharp-1-1 2.5

Siltstone, medium-gray, obscurely bedded, partly sandy, clayey; some caroonaceous plant fragments; includes at $1.5 \mathrm{ft}$. above bas a $1-\mathrm{ft}$. bed of mecium-gray friable medium-grained saris tone overlain by a i-ft. bed oi

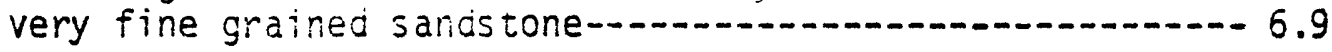

Shale, medium-dark-gray, carbona ceous-_-n-1 0.1

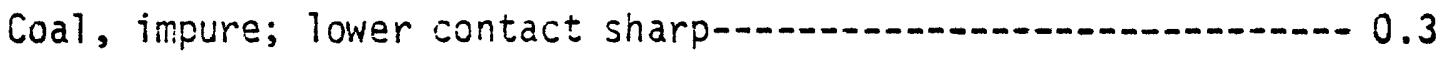

Siltstorie and sandstone; siitstone, medium-gray, obscurely bedded, clayey; few carooraceous plant fragments

(randomly oriented at top); incluaes at 0.3 and about $4 \mathrm{ft}$. above dase thin (1ess than $0.1 \mathrm{ft}$. thick) coaly zones mostly comoosed of flattered coaifified logs: sandstore ( $3 \mathrm{ft}$. thick and $4 \mathrm{ft}$. above base of unit), medium-gray, obscuroiy bedded, medium-grained, subangular; overlain gradationaily by platy-bedced(?) friable very

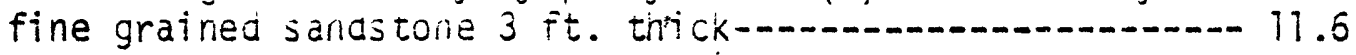

Coal and interbedded siltstone and shale; coal, impure in upper half, forms beds 0.2-0.5 ft. thick; siltstone, medium-gray and medium-brown, obscurely bedded, clayey; many carbonaceous plant fragments: forms 2 beds $0.1-$ $0.2 \mathrm{ft}$. thick in lower $1 \mathrm{ft}$.; shale, medium- to darkgray, probably fissile (obscure), rostly carbonaceous; slickensides in lower bed; forms 2 beds $0.1 \mathrm{ft}$. thick

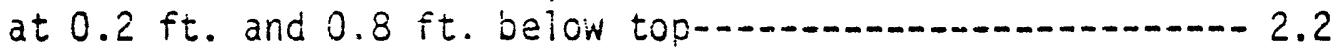

Siltstone, light-gray-hackly-weathering, obscurely bedded, slightiy clayey; abundant carocnaceolis plant fragments - 0.4 
Coai and interbedded siltstore and shale; generaliy similar

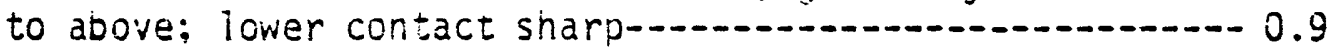

Siltstone, brownish-gray, cbscure platy-bedded, sandy, clayey, carbonaceous; abundant large coaifified wood fragments randomly oriented in part; lower contact sharp-......-...--1.1

Sandstone, medium-grav, s?abby-weathering, obscurely bedded, medium-grained, subanguiar, si it t; numerous smail carbonacecus plant fragments; probably pinches out lateraliy; lower contact snarp and uneven-..-..-..- 2.

Siltstore, nedium-gray, slabby-weathering, obscurely bedded, clayey; small and large carbonaceous plant fragments randomly oriented; lower contact fairiy sharp-............- 2.3

Siltstone, dark-gray, finely sandy, clayey, carbonaceous; abundant carbonaceous olant fragments on bedding;

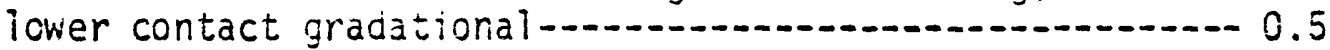

Sandstone, medium-gray, obscurely bedded, very fine grained, subangular, very silty, clayey; base concealed-............ 2.+ Lower part of exposed rocks not measured 
Measured section io

Location: Gully exposure on west side of Fox Creek at center of north line liw $1 / 4$ SW $1 / 4$ sec. $33, T .3$ S., R. $10 \mathrm{~W}$., Seldovia D-3 quadrangle. The base of this section is about $25 \mathrm{ft}$. above Fox Creek. The rocks were wet and poorly exposed, and most of the section was dug out.

Feet

Tertiary rocks -- Kenai Group, Sterling Formation

Upper part of exposed rocks not measured

Coal, very impure; inciudes many very thin oeds of siltstone--- 1 .

Unexamined interval, mostly siltstone and sandstone; ir cludes $0.3-\mathrm{ft}$. bed of cartonaceous shale $23 \mathrm{ft}$. beiow top-... 60.

Sandstone, not examined or sampled; lower coritact sharp-.....-.- 10.

Siltstone, medium-gray, obscurely bedded, very clayey;

carbonaceous plant fragments; scattered ironstone nodules near middle; upper half includes beds of very fine grained sandstone as much as $1.2 \mathrm{ft}$. thick-................. 13.

Covered interval-1. 6.5

Sands tone, medium-gray, obscurely bedded, soft, friable, very fine to medium-grained, subangular, silty-.........-. 4.4

Siltstone, medium-gray, partly iron-stained, obscurely bedded, clayey; scattered carbonaceous plant fragments; upper half includes 2 beds, each about $0.2 \mathrm{ft}$. thick, of very fine grained ciayey sanos tone; at 0.2 $\mathrm{ft}$. below top a thin bed (less than $0.2 \mathrm{ft}$. thick) of dark-gray carbonaceous shaie and brownish-gray silt-

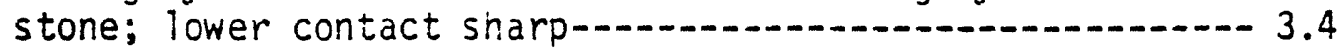

Sandstone, medium-gray, probably partly laminated to platybedded, very fine grained, subangular, silty, ciayey; poorly observed-_- 3.

Covered interval-_- 2. 
Sandstone, mecium-gray, obscurely bedded, friable, fire-

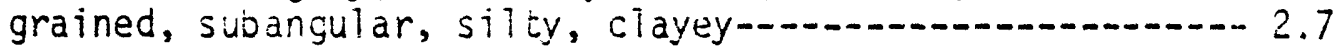

Siltstone, medium-gray, obscureiy bedded, very clayey; some carbonaceous plant fragmenis; inciudes $0.2-f t$. bed of carbonacecus siltstone about $1.5 \mathrm{ft}$. below top-..........-4.8

Sandstone, medium-gray, very fire grained, clayey-............-2 2.

Covered interval-_.

Sandstone, mediurn-gray, probabiy laminated to platy-bedded, very fine grained, subangular, silty, clayey; iower

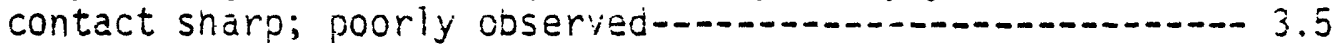

Siltstone, medium-gray, obscurely bedded, clayey; some carbonaceous piant fragments; lower contact prooabiy gradational

Sandstone, medium-gray, laminated to platy-bedded (mostly upper haif), very fine grained, subanguiar, slightly silty; some carbonaceous plant fragments; "ew very thin beds of medium-grained sarids tone in upper-middle part; includes mary beds, $0.1-0.5 \mathrm{ft}$. thick, of medium-gray si 1 ts tone--

Siltstone, medium-gray, partly iron-stained, obscurely bedded, clayey; carbonaceous piant fragments mostly scattered but abundant in upper $0.5 \mathrm{ft}$.; includes near middle a bed of medium-gray very fine grained sandstone about $0.5 \mathrm{ft}$. thick; few very thin beds of brownish-gray caroonaceous siltstone in upper $0.3 \mathrm{ft}$; iower contact sharp-1..- 3.9

Sandstone, medium-gray, partly laminated to platy-bedded, mostly very fine grained, upper half partly finegrained, angular to subangular; few carbonaceous plant iragments; includes several medium-gray siltstone beds about $0.5-1 \mathrm{ft}$. thick; lower contact gradational-1-14

Siltstone, medium-gray, partly laminated to piaty-bedded, clayey; scattered carbonaceous plant fracments; includes numerous beds, about $0 . i-0.2 \mathrm{ft}$. thick, of medium-gray very fine grained sands tone-_............................. 3

Coal; lower contact sharp-1 
Shale $(10 p-4)^{*}$, medium-gray, laminated to platy-Dedaed; some carbonaceous plant fragmenis; lower contact

sharp-a- 0.8

Sandstone, medium-gray, obscurely bedded, friable, fine- to

medium-grained becoming very fine grained near cop,

subangular, ciayey; carbonacezus plant fragments in

upper part; includes at toc a 0.i-ft. bed of dark-

gray to brownish-gray laminated to platy-bedded carbo-

naceous siltstone with abundant piant fragmerits; lower

contact sharp-_. W

Shale, medium-gray, locally iron-stained, obscurely jedced; becomes silistone in upper half: some carbonacecus plant fragments; lower contact gradationai-..........-.-.-.- i.

Shale, dark-gray, fissile to platy-bedded, carbonaceous; abundant carocnaceous plant fragments; many imoure coal stringers; lower contact gradationa!-................. 0.6

Tuff, yellowish-gray to yellowish-brown, thin-slabbyweathering, medium-grained; includes, mostly in lower half, laminae and very thin beds of friabie mediumgrained sandstone showing wavy bedding and "micro-

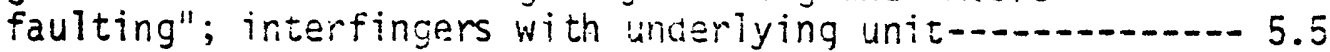

Siltstone, inedium-gray, obscurely bedded, clavey; carbonaceous plant fragments generally scattered but abundant in several beds about $0.5 \mathrm{ft}$. thick in upper $3 \mathrm{ft}$.; includes at top a $0.2-\mathrm{ft}$. bed of medilimi-gray friable medium-grained sandstone; base concealed-.......... 8.+ 


\section{Measured section 11}

Location: Creek-bed and hillside exposures on Swift Creek from SE. 1/4 SW $1 / 4 \mathrm{NE} 1 / 4$ downstream to iin $1 / 4$ iNE $1 / 4$ SE $1 / 4$ sec. $23, T .4$ S., R. $11 \mathrm{~W}$. , Seldovia D-3 quadrangle. This location lies between localities 168 and 169 of Barnes and Cobb $(1959$, p1s. 18, 19).

Feet

Tertiary rocks -- Kenai Group, Sterling Formation

Upper part of exposed rocks not measured

Coal and interbedded shale, poorly cbserved; forms prominent overnanging ledge on steep hillside--.------approx.- 6.

Sandstone, medium-gray, partly iron-stained, obscure laminated to platy-bedded, cross-Dedded, friable, very fine to fine-grained, subrounded, slightly clayey; becomes finer grained upward and upper haif grades into medium-gray obscurely bedded silts tone with many large carbonaceous woud fragments at nign angle to

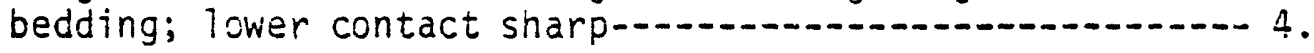

Sandstone, similar to above but very fine grained; upper half becones siltstone as above; lower contact sharp-...-- 5.6

Sandstone, medium-gray, partly iron-stained, obscure 1 aminated to platy-bedded, cross-bedded, friable, very fine to fire-grained, subangular, clayey; becomes finer grained upward and upper one-fourth grades into medium-gray ob;cureiy bedded siitstone with abundant carbonaceous plant fragments and some large roots(?); very carbonaceous in upper $0.1 \mathrm{ft} . ;$ lower contact sharp-1.-1..-. 6.6

Siltstone, medium-dark-gray, obscurely-bedded, partly platybedded, clayey; includes at $2 \mathrm{ft}$. above base a zone about $4 \mathrm{ft}$. thick of medium-dar'k-gray platy-weathering obscurely bedied fine- to medium-grained sandstone with a few interbeds of silistone; lower contact of 4-ft. zone sharp and ucoer contact gradational; lower

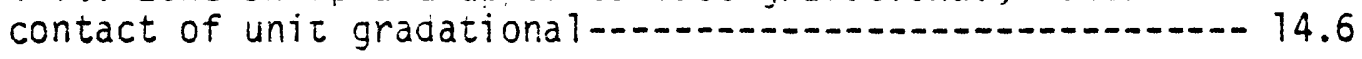

Sandstone, rediuin-gray, obscurely-bedded, friable, very fine to fine-grained, subangular; few coarse grains at base; becomes finer grained ucward, micaceous and very silty in uppermost part; lower contact sharp-......-.- 6. 
Silts tone, medium-gray, obscurely bedded, clayay; scrie carbonaceous plant fragments; includes at base $0.8-$ $\mathrm{ft}$. bed of very fine grained sandstone-_................. 4.5

Shale $(11 P-28)^{*}$, redium-gray; abundant carbonaceous plant fragments -

Sandstone, medium-gray, obscureiy laminated, friable, very fine grained, subangular, clayey; includes ac top 0.1 $\mathrm{ft}$. bed of dark-gray carbonaceous siltstone-......-...-.-1.3

Siltstone, mediur-gray, obscureiy bedded; siickensides in upper $0.5 \mathrm{ft} .:$ carbonacecus arinations in part; carbonaceous olant fragments acundant in oart; lower contact sharp-1..-...- 5.5

Sandstone, medium-cray, partly iron-stained, obscure iaminated to plazy-bedded, cross-bedded, friaole, very fine to fine-grained, subanzilar; includes at about $3 \mathrm{ft}$. above base a $1-\mathrm{ft}$. bec of medium-gray silitstone that inciudes some ironstone rodules about $0.2 \mathrm{ft}$. thick; lower contact of siitstone gradational and upper contact sharp; lower contact of unit sharp-......-.-.-9.5

Sandstone, medium-gray to pale-broun, partly ironstained, partiy platy-leatnering (upper one-third), laminated to piaty-bedded, cross-bedded, friable, very fine grained, angular to stianguiar, very silty in upper one-third; few iron-rich beds less than $0.2 \mathrm{ft}$. thick; inclides beds of iredium-gray siltstone about 1 ft. thick at $4.5,7,11,13$, and $17 \mathrm{ft}$. above base; ironstone nodules as much as $0.2 \mathrm{ft}$. thick in lower siltstone and $a: 33 \mathrm{ft}$, atove base; sandstone beds commonly inciuce some fine grains at base ana grade upward into siltstone; uppermost siltstone includes 0.2-ft. ironstcre ledge and 0.05-ft. bone coal near

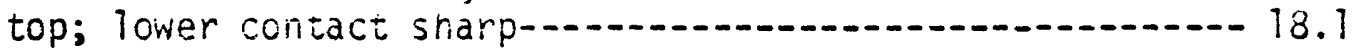

Siltstone, medium-gray, obscurely bedded, sandy at base, clayey; abundant carbonaceous olant fragments; includes at $3 \mathrm{ft}$. above base a 3-ft. zone of platy-weatnering siltstone interlaminated with very fine grained sandstone; 0.1-ft. bed of medium-aark-gray carboraceous siltstone at top; lower contact gradational-...............- 8.1 
Sandstone, medium-gray, partly iron-sta ined, obscure laminated to platy-beaded, crosj-bedded, friabie, very fine grained, subansular, very silty in upoer $0.5 \mathrm{ft}$.; small cartonaceous plant fragments: inrludes $0.3-f t$.

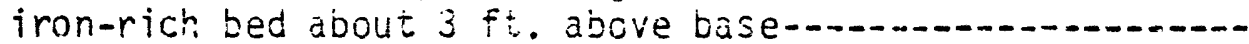

Siltstone, mediun-gray; coscurely bedded, cicyey; abundant smail carbonaceous wood fragments: large coalified wood frajments abcut i $f t$. above base; includes $i-f t$. bed of medium-gray friable very fine grained sandstone at $2.5 \mathrm{ft}$. abcve basa and similar bed 0.3 fi. thick at $0.4 \mathrm{ft}$. below top; $0.5-\mathrm{ft}$. bed of carbonaceous siltstone about $4.5 \mathrm{ft}$. above base; $0.1-f t$. medium-darkgray platy-weathering carbonaceous shale at top-.........

Coal, platy-weathering

Shale, medium-gray, obscurely bedded; many carbonaceous plant fragments

Coal, Ged R, platy-weathering; lower $2 \mathrm{ft}$. includes 4 partings, 0.05-0.1 ft. thick, of brownish-gray

siltstone; !ower contact jharp-........................... 3.5

Siltstone, medium-gray, slabby-weathering, obscure platybedded; non-bedded(?) in upper ? ft. (11P-21)*; partiy sandy, clayey; upper two-tnirds of unitincludes snine large caroonaceous wood fragnents mostly at high angle to bedding; lower contact sharp-....................... 14.7

Sandstone and interbeded siltstone; sandstone, medium-gray, partiy laminated to platy-bedded, nostly friable, very fine to fine-grained, subangular, clayey; forms ceds generally $1-3$ ft. thick; slitstore, medium-gray, obscurely bedded, finely sandy, clayey; some carbonaceous plant fragments; forms beds about $1 \mathrm{ft}$. thick except for a $3 \mathrm{ft}$. bed about $3 \mathrm{ft}$. above base-............ 13.5

Siltstone, medium-gray, platy - to poor conchoidal-weathering, mostly piaty-bedded, clayey; scattered small carbonaceous plant fragments; lower contact gradational-.- 4.

Shale, brownish-black to black, olaty-weathering, laminated to platy-bedded, $h=r d$, siity- 
Coal, impure; iower contact sriarp-a.t.-. 0.7

Sandstone, medium-gray, partiy iron-stained, laminated to platy-bedded, very iine to fine-grained becoming very fine grained in uoper part, sutangularr; many carbonaceous plant fragments and sote large coalified wood fragmerts in upeer i ft.; uper half includes mediumgray siltstone in beds doout $0.1 \mathrm{ft}$. thick; $0.2-\mathrm{ft}$. bed of non-bedcied siltstone at top; lower contact

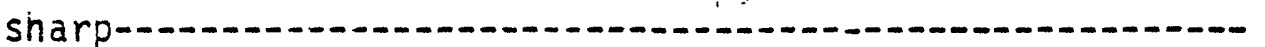

Siltstone, mecium-gray, iaminated to piaty-bedded, ciayey; some carbonaceous plant fragments randomiy oriented in part; includes near midcle ianinae and very thin beds of very fine grained sardstone; jower contact gradationai-....

Siltstone, mediun-dark-gray, ooscurely bedded, clayey; abundart caroonaceous piar: fragrents; inciuces at $0.2 \mathrm{ft}$. ajove base very trin irreguiar ierizes of lightbrown friadia vell sorted siltzcone; icwer contact sharp.-...

Sandstore, medium-gray, partiy iron-stained, locally cliffforming, mostiy platy-bedded, cross-bedued, nediumgrained at base grading uprird to tine-grained about $4 \mathrm{ft}$. above base and yery fine grained about $14 \mathrm{ft}$. above base, subangular to subrounoed; mary iron-ricn Tenses about i ft. thick in midle part; fev beds of mediumi-gray siits tone as much as $1 \mathrm{ft}$. thick in upper

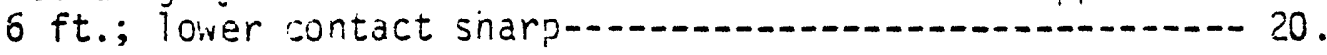

Silts tone, medium- to dark-gray, obscureiy becded, upper $1 \mathrm{ft}$. mostiy sandy, clayey; carbonaceous olant fragments abundant in part, especialij near top; inciludes about $1-f t$. bed of very fine grained saricstone about $1 \mathrm{ft}$. below top; uppermost $0.2 \mathrm{ft}$. iron-rich and nard; lower contact sharp-a.- 9.5

Sandstone, rediun-gray, ooscureiy bedded (lower $2.3 \mathrm{ft}$.) and laminated to platy-dedaj, cross-bedjed, friabie, very fine grained, subangular, silty, clayey; some small carboneceous fragrients; lciver 2.3 ft. partiy fine-grained, local iron-rich zone 0.1 it. thick about $4.5 \mathrm{ft}$ above basa; includes in upper $5 \mathrm{ft}$. several beds of mediuri-gray si?tstore rostly less than $0.5 \mathrm{ft}$.

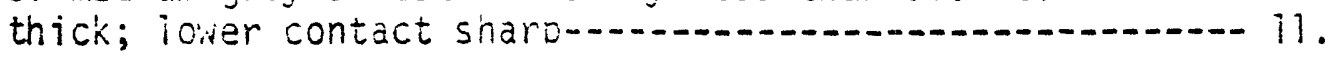


Siltstone, medium-gray, hackly- to chunky-weathering, mostiy platy-bedded, partiv laminated (lower I ft.); clayey, carboraceous plant fragrents abundant in lower $1 \mathrm{ft}$. and about $g$ it. zoo\% base; severai courses of scattered ironstones as much as $0.2 \mathrm{ft}$. thick; inciudes few beds of very fine grained clayey sandstore, less than $1 \mathrm{ft}$.

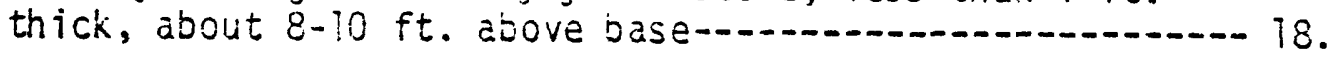

Shale (11P-13)*, madium- to medium-dark-gray, conchoida weathering (upper naif), poor fissi ie to piat;-bedded;

few ironstone rodules about $0.3 \mathrm{ft}$. thick in uoper half; abundent carbonaceous plant fragments; aburidant large coalified slant fragments in niddle and at top--

Coal, Bed $Q$, fairly blocky - to partly platy-weathering; forms nign waterfali; lower contact sharp-

Siltstone, mediun-1 ight- to medium-gray, partly ironstained, blocky- to pcor conchoidal-weathering, laminated to platy-bedied, regularly becded, hard, clayey; carbonaceolis plant fragrents in uoper part; includes lenticular coal beds as much as $0.3 \mathrm{ft}$. thick in upper $1 \mathrm{ft} .1$.

Coal, Bed Q (lower bench), blocky-weathering; inciudes at $0.5 \mathrm{ft}$. asove base a $0.1-\mathrm{ft}$. oed of mediun-brownweathering carconaceous shale with fine-grained sphericles of bog iron(?); at $2 \mathrm{ft}$. above base a 0.2 ft. lenticular bed of light-gray-weathering 1 igntbrown siltstone containing pyroclastic grains; at 0.2 ft. below top a lenticular bed cf light-gray finegrained tuff as much as $0.3 \mathrm{ft}$. thick; lower contact sharp-1.-1

Siltstone, medium-gray, partly laminated, mostly obscurely bedded, finely sandy in vart, clayay; carbonaceous plant fragments abundant in part; ironstore rodules $0.2 \mathrm{ft}$. thick about 5 and $10 \mathrm{it}$. above base; $3-\mathrm{ft}$. bed of friatle :ery fine to fine-grained sandstorie about $6 \mathrm{ft}$. above base; very thin beds of laminated very fine grained sandstone in $1-f t$. zone about 15 ft. above base; 0.2-ft. bed of carbonaceous siltstone about $17 \mathrm{ft}$. above base; $3-\mathrm{ft}$. Ded of laminated to cbscureiy bedded partly frizble very fine grained sands tone about $20 \mathrm{ft}$. aoove base; lower cortact fairly sharp 
Sandstone, medium-gray, partly iron-stained, partly laminated, friabie, fine-grained at base becoming very fine grained upward, subangular; some clayey sands tone in upper part; includes 1-ft. siltstone bed about 1.5 ft. below top; lower contact sharp and probably disconformable-_. 11.2

Coal, Bed P, lower contact sharp-a. 3.1

Siltstone, medium-gray, partly iron-stained, mostly obscurely bedded, partly laminated, clayey; abundant carbonaceous olant fragments in part: Few root?? fragments in upper $0.5 \mathrm{ft}$.; includes few beds, iess than $1 \mathrm{ft}$. thick, of friable very fire to fine-grained sandstore; 3 jeds of carbonaceo'is snaje, iess tnain 0.3 $\mathrm{ft}$. thick, about $5 \mathrm{ft}$. above oase, near rijdie, and near top-16.

Sandstone, medium-gray, friable, very fine to finegrained, subangular, silty; some smail carbonaceous plant fragments; lower contact fairiy sharp-.-.-.-.-.-.-.-- 3.

Siltstone, medium-gray, mostly obscuroly bedded, some laminated to piaty-bedded, ciayey; abundent caroonaceous plant fragments in part; few coaifified sood fragments randomly oriented in oart; upoer part includes few $5 \equiv d s$, less than 1 ft. thick, of iaminated very fine grained sands tone; lower contact gradationa i-

Sandstone, medium-gray to grayish-brown, partly ironstained, lailinated to platy-bedded (upper half), friable (lower haif), very fine grained, subargular, silty, ciayzy; includes interbedded redium-gray' siltstore in liper $2 \mathrm{ft}$; l liver contact sharp-............. 7. i

Siltstone, medium-gray, obscurely bedded, partly very finely sandy, clayey in upper $0.5 \mathrm{ft}$.; carbonaczous plant frag-

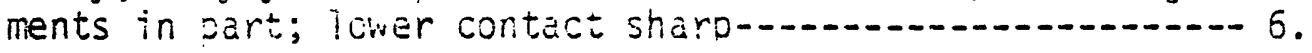

Sandstone, medium-gray, lightly iron-stained in part, probably lamirated to ol aty-bedded (odscure), crossbedded, friacle, fine-grained, oartly very fine grained in uejer 5 it., suangular; lenses of ironcemented sardstcne less than $0.5 \mathrm{ft}$. thick; lower contact sharp--..-..-.

Coal, Bed 0 (upper bench) - 
Shale, medium- to dark-gray, fissile to poor platy-bedded, very carbcnaceous in part; abundant carbonaceous plant fragments; includes 0.?-ft. ccal bed in middle-1._- 0.8

Coal, platy-weathering-_.

Shale $(11 P-2)^{*}$, medium-gray, poor platy-weatheririg, obscurely bedded; aburidant small carbonaceous piant fragments and numerous large coalified wood fragments -............. 0.9

Coal, Bed 0, fairly blocky-weathering; forms waterfall about 5-8 ft. high in creek; lower contact sharp-.............. 5.2

Sands tone, redium-gray, slabby-wedthering, partiy laminated, cross-bedided, mostly iriable, very fine to finegrained, subangular, sligntly claygy; upper $1.5 \mathrm{ft}$. becomes very iine grained and very silty; uoper half includes caroonaceous laninae and large coalified rood fragments along bedding and also randomiy oriented;

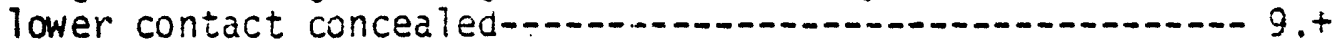


Measured section 12

Location: Hillside and creek-bed exposures in large unnamed canyon on nor theast side of Swift Creek in ii $1 / 2 \mathrm{SE} i / 4 \mathrm{SW} 1 / 4 \mathrm{sec} .24, T$. 4 S., R. $11 \mathrm{~W}$., Seldovia $\mathrm{v}-3$ auadrangle. This location is approximately the same as iocality 170 of Barnes and Cobb (1959, pls. 18, 13).

Feet

Tertiary rocks -- Kenai Group, Sterling Formation

Upper part of exposed rocks not measured

Coal, Bed P-1.-1

Interval, not studied or sampled; mostiy siltstone; includes sandstone bed about $15 \mathrm{ft}$. thick about $4 \mathrm{ft}$. below top--.- 72 .

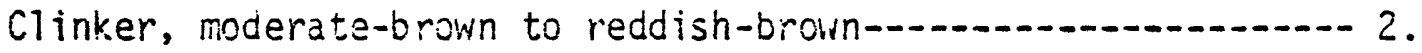

Coal ash, Bed 0, reddish-brown to yellowish-brown; includes 0.3-ft. bed of weatnered powdered coal at

base-1-1. 0.8

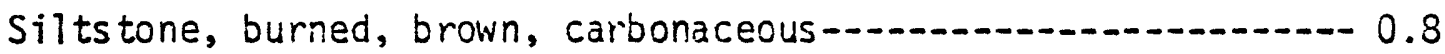

Siltstone and interbedded sandstore; siltstone, mediumgray, partly iron-stainad, Door slaboy-weatnering, cbscurely bedced, clayey; some carbonaceous plant fragments; ironstone rodules as much as $0.2 \mathrm{ft}$. thick in basal $1 \mathrm{ft}$. ; includes $0.2-\mathrm{ft}$. coal bed about $0 . \overline{3}$ ft. above base of unit $(12 P-33--$ silts tone below coal)*; sandstone, medium-gray, partiy iron-stained, slabby-wedthering, laminated to placy-oedded, crossbedded, soft, friable, very fine to fine-grained, subangular, slightiy silty; includas carbonaceous laminas about 2.5 ft. above base of unit; forms beds as much as $3 \mathrm{ft}$. thick; lower contact fairly sharp-......- 11.8

Sandstone, medium-gray, iron-stained, iaminated to platybedded, cross-bedded, sof $\tau$, friabla, ine-grained (lower $3 \mathrm{ft}$.) becoming very fire to fine-grained in remainder, subangular; lcher contact sharp and prob-

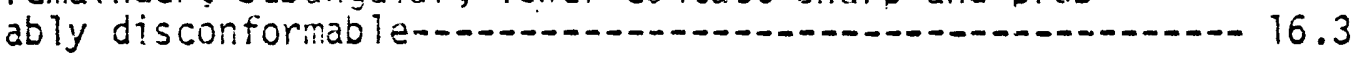


Siltstone and interbedded sands tone; similar to interbedded unit beiow; siicstorie beds comonly 2-3 ft. thick and sandstone beds about 1-2 ft. thick; abundant coal films; includes ironstone nodules about $0.2 \mathrm{ft}$. thick near base of unit and about 3.5-5 ft. below top-...- 20.5

Siltstone and interbedded sanistone; similar to interbedied unit below; siltstone beds about $+-5 \mathrm{ft}$. thick and

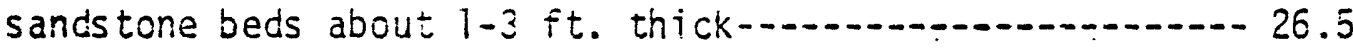

Siltstone and interbedded sandstone (subequal arounts in beds commonly about $3 \mathrm{ft}$. thick); siltstone, rejiumgray, poor slabby-weatrering, obscurely bedded, clayey; some carbonaceous plant fragments; sands tone, rediumgray, partiy iron-stained, sl abby-weacnering, la tinated to platy-bedded, cross-bedced, soft, friabie, very fine to fine-grained, subanguiar, ciajey; some sandstone beds become finer grained idyard; contacts between siltstone and sandstone mosily gradational to fairly sharp; unit includes a bec of redium-dark-gray carbonaceous siltstone auout $0.5 \mathrm{rt}$. thick at about 4

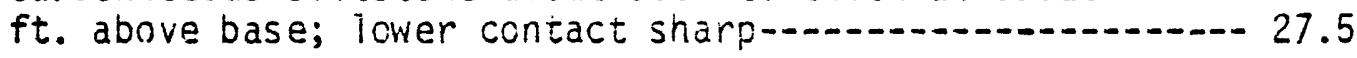

Sandstone, medium-gray, iron-stained, locaily poor cliffforming, obscurely bedded, soft, friacle, very fine to fine-grained, subarigular, clayey; vecorres finer grained upward and grades into silistone at 12. it. above base; inciudes $0.5-\mathrm{ft}$. bed of mediun-dark-gray carbonaceous siltstone about $1.5 \mathrm{ft}$. below top; lower contact sharp and possibly disconformable-...............- 15.

Silts tone, medium-light-gray, chunky-weatherirg, rostly obscurely bedded, partly irregularly laminated, clayey; some carbonaceous plant fragments; basai $1 \mathrm{ft}$. includes lenses of bone coal as mucn as $0.1 \mathrm{ft}$. thick; ironstone nodules $0.2 \mathrm{ft}$. thick at $0.2 \mathrm{ft}$. below tor;

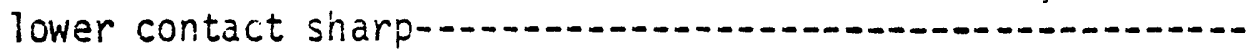

Siltstone, dark-gray to brownish-gray, partly iron-stained, poor fissile to platy-oedded, finely sandy, clayey, very carbonaceous; abundant carocracecus plant and wood fragments; few bone-coal stringers 0.05 it. thick; 0.2-ft. imoure coal at top; icwer contact sharp--.-1.

Siltstone, mediun-gray, obscurely bedded. sandy; some carbonaceous Dlant fragrents; lower contact fairly sharp-.....- 0.0 
Sandstone, medium-gray, laminated to platy-bedded, crossbedded, friabie, very iine grained, subangular, silty at base, clayey; finely carbonaceous laminae; lower contact gradational

Siltstone, medium-gray, slightly iron-stained, hacklyweathering, obscurely bedded, clayey; few carbonaceous plant fragments; includes $0.5-\mathrm{ft}$, bed of very fine grained sandstone in middle; lower contact sharp-- 4.

Siltstone, dark-gray, poor fissile to olaty-bedded, hard, finely sandy, clayey, very carbonaceous; icwer contact sharp-- 0.5

Siltstone, medium-gray, slabby- to hackly-weathering, obscurely bedded, partly laminated, sandy in lower 3 ft. and upper 5 ft., clayey; abundant carbonaceous plant fragments in part; lower contact sharp-............. 14.

Siltstone, dark-gray, lamiriated to platy-bedded, ciayey, carbonaceous; many bone-coal laminae and stringers;

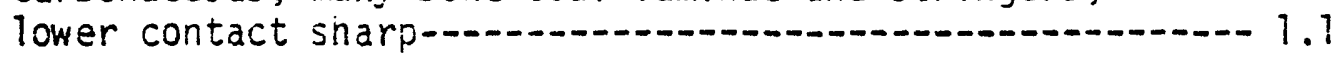

Sandstone, medium-gray, mostly obscurely bedided, partiy laminated to platy-bedded, slightly limy, very fine grained, subanguiar, partly silty; carbonaceous laminae in part; few beds of medium-gray siltstone as much as $1.5 \mathrm{ft}$. thick; lower contact sharp-............................ 18.6

Coal, Bed N, blocky-weathering; probably very impure in upper $0.3 \mathrm{ft}$; includes at $2.1 \mathrm{ft}$. beiow top a $0.2-$ $\mathrm{ft}$. bed of weathered caroonaccous shale and silts tone; at $1.5 \mathrm{ft}$. below top a $0.15-\mathrm{ft}$. bed of weathered dark-gray to bläck carbonaceous shale and brown siltstone; lower contact sharp-............. 3.7

Siltstone, medium-gray, obscurely bedded, clayey, sandy in upper $0.3 \mathrm{ft}$.; many carbonaceous plant fragments; lower contact sharp-1

Sandstone, medium-gray, laminated to platy-bedded (lower $1.5 \mathrm{ft}$. ) ard cbscure $1 y$ bedded (upoer $0.6 \mathrm{ft}$.), partly cross-bedded (probabiy lamirar cype), very fine to fine-grained becoming fire-grained in upper $0.5 \mathrm{ft}$., subangular; aburidant carcoraceous laminae in lower part; Tower contact sharp--...- 2.1 
Siltstone and interbedded sancistone (alternating beds commonly 1-2 ft. thick), slabby-weathering; silts tone, medium-gray, mostly obscureiy bedded, clavey; sandstone, medium-gray, very fine grained, subangular, silty, clayey; many carbonaceous laminae and plant frag-

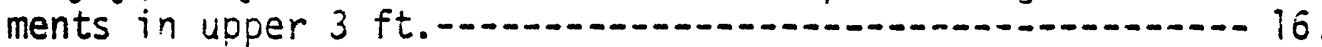

Siltstone, medium- to medium-dark-gray, slabby-weathering, mostly obscurely tedded. partly laminated to platybedded, partiy sandy, clayey; includes at $2 \mathrm{ft}$. above base a 1.5-ft. bed of medium-gray cbscurely bedded friable fine- to medium-grained sandstone; at about $12 \mathrm{ft}$. above base a 2.2-ft. bed of redium-dark-gray laminated to platy-bedded cross-bedded friable very fine to fine-grained sandstone; lower contact sinarp-.....-. 15.

Siltstone, medium-dark-gray, poor platy-bedded, clayey, carbonaceous; includes $0.1-\mathrm{ft}$. bed of bone coai at

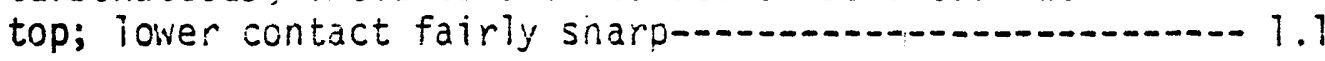

Siltstone, medium-gray, obscurely bedded, slightly clayey, very saridy in lower part; rany caroonaceous p? ant fragments, few large randomiy or ericed carbonaceous

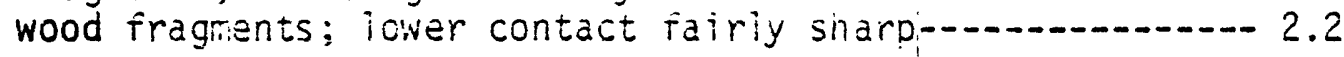

Siltstone, medium-dark-gray, poor platy-bedded, clayey; abundant carbonaceous plant fragments; lower contact sharp-1. 0.5

Sandstore, medium-gray, mostly obscurely bedded, partly laminated to platy-bejded, very fine to fine-grained, subangular; abundant caroonaceous laminae in part; unit largely consists of aiternating beds, about $1 \mathrm{ft}$. thick, of laminated to platy-bedded very fine grained sandstone and coscurely bedded fine-grained sarastone; includes 2 beus, each about 1 ft. thick, of mediumgray obscurely iaminated clayey siltstone at about 6.5 and $8 \mathrm{ft}$. above base; upper $2 \mathrm{ft}$. becomes very silty and graces into siltstone with abundant carbonaceous plarit fragments; icwer contact gradational-......- 12.3

Siltstone, brownish-gray to medium-gray (top), obscurely bedded, probably oartly laminazed, clayey; somie carbo-

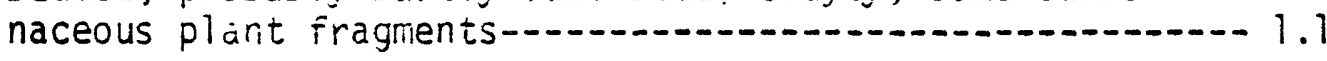

Coal, platy-weathering; includes at $0.1 \mathrm{ft}$. below too a $0.1-f t$. parting of brownish-gray weathered shale with abundant carbonaceous plant fragments; lower contact sharp-a- 1.3 
Sandstone, medium-gray, iaminated to platy-bedded, partly obscurely bedied, partiy friable (2-ft. zone $3 \mathrm{ft}$. above base and upper $2 \mathrm{ft}$.), very fine grained (finegrained in lower friabie zone), subangular to subrounded; carbonaceous laminae in part; includes few beds, commonly about i ft. tinick, of medium-gray obscurely bedded siits tone; lower cortact fairly sharp--..-1

Sands tone, iledium-gray, mostly obscuraly bedded, laminated to platy-oadded in middle, oartly friabie, mostly fine-grained, subangular; very iine grained, very silty and ciayey in midile part; iower contact fairly sharp-a.- 5.7

Siltstone, medium-gray, partly iron-stained, obscurely bedded, clayey; some carbonaceous plant fragments; brownish-gray and very carbonaceous in basai 0.2 ft.; includes $1.5-f t$. bed of medium-gray very fine grained sandstone about $1 \mathrm{ft}$. above base-................ $i . i$

Coal-1.2. 0.6

Siltstone, brownish-gray to black, laminated to platybedded, clayey, carbonaceous -................................. 0 0 0.5

Silts tone, medium-gray, obscurely bedded, clayey; abundant carbonaceous piant fragrients-............................. 0.5

Coai $0.3-0.5$

Silts tone, medium-gray (lower $0.5 \mathrm{ft}$.) and brownish-gray to dark-gray, riostly poor platy-bedded, fineiy sandy;

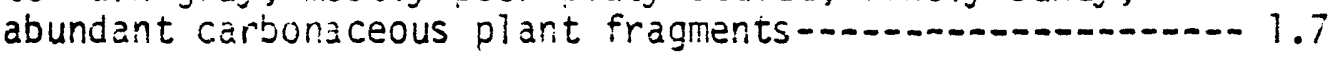

Shale, brownish-gray to black, laminated to platy-bedded, very carbonaceous; abundant plant fragments-.............. 0.4

Claystone (volcanic ash?), iight- to very light gray, faintly laninated; abundant carbonaceous plant

fragments; Tenticular-....................................... 0-0.2

Siltstone, medium-gray, obscurely bedded, clayey; abundant carbonaceous plant fragments; coal stringer as mucn

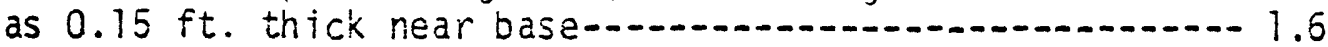

Coal-1-1 1.5 
Siltstone, medium-gray, foor slabby-iweathering, obscurely bedded, partly clayey, partly finely sindy; many carbonaceous plant fragments; brownisn-gray and very carbonaceous in upper $0.2 \mathrm{ft}$.; : ower contact gradationa 1 -

Sands tone, medium-gray, poor slabby-weathering (upper part), mostly laminated to piaty-bedded, cross-bedded, fine-grained (10ver $16 \mathrm{ft}$.) to very fire grained and very silty in lipper part, angular to subanquiar; includes clasts about $0.5 \mathrm{ft}$. long of hard very ine grained sandstone at 4-5 ft. agove base; numerous large irregular carbonaceous olant fragments in upper

$10 \mathrm{ft.}$.

Coal, very impurs in upper part; at $0.4 \mathrm{ft}$. above base includes 0.5-ft. bed of medium-gray obscurely bedded conchoidaliy fracturing shale $(12 P-3) *$ with sickensides ard abundant carbonaceous piant fragments;

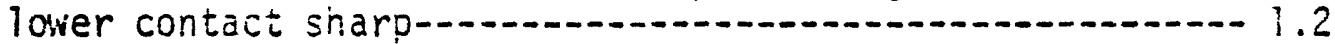

Siltstone, medium-gray, partiy iron-stained, chunky-weathering, platy - to very thin bedded (lower half), sandy (upper half), ciayey; abundant carbonacecus piant fragments mostly randomly oriented-....................... 4.8

Coal; lower contact sharp-an- 0.8

Sandstone, medium-gray, partly iron-stained, mostly crossbedded, obscursiy bedded in Tower 3-4 ft., mustiy friabie, medium-grained (icwer $8 \mathrm{ft}$.) grading lipward to very fine grained and mostiy very silty (upper 10 ft.), subangular; lower $3 \mathrm{ft}$. includes scatterad rounded pebbles commoniy less than $0.05 \mathrm{ft}$. in diameter; few large coalified wood fragments 3-5 ft. above base; $0.5-\mathrm{ft}$. iron-rich zone at base of scour about $7 \mathrm{ft}$. above base; locally abundant carbonaceous laminae and stringers about $8 \mathrm{ft}$. above base; upper $10 \mathrm{ft}$. includes several beds, commonly 0.5-1 ft. thick, of medium-gray sandy siltstone; 0.5-ft. siltstone bed at top contains abundant randomily oriented carbonaceous piant fragments; unit weathers to steep rounded gully sides (probably poor cliff-former localiy); lower contact sharp-- prob cliff-former localiv); iower contact 
Siltstone and interbedded sandstone; silistone, mediumgray, large chunky-weathering, ooscurely bedded, clayey; abundant carbonaceous piant fragments in part (especially near base and in upper half); forms beds commoniy 3-5 ft. thick in lower half and 1-3 ft. thick in upper haif; sanastone, medium-gray, partly laminated to platy-bedded, partly cross-bedded, mostly very fine grained, some fine-grained in lower half, subangular; forms beds commoniy 0.3-1.5 ft. thick in lower half and 1-2 ft. thick in upper haif; sandstone makes up about one-third of lower half and two-thirds of upper half--a-c- 35.

Coal; loca!ly includes flattened conical-shaped tree-root(?) masses at top; lower contact sharp-a-n 0.9

Siltstore, medium- to medium-dark-gray, brown tint in basal 0.2 and upper $0.2 \mathrm{ft}$, chunky-weathering, obscurely bedied, ciayey; abundant carbonaceous piant fragmerits; faw iarge coaifified wood fragments oriented at high angle to bedding; lower contact sharp-..........-.-- 2.4

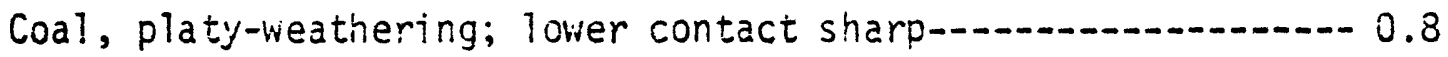

Siltstone, medium-gray, obscursiy bedded, ciayey, mostly sandy in upper part; abundant caroonaceous plant fragments; includes in middle abcut $0 . \varepsilon-f t$. bed of medium-gray platy-bedded very fine grained sandstone;

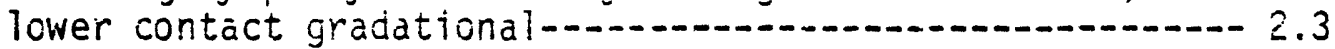

Sandstone, medium-gray, partiy iron-stained, obscure

platy-bedded, cross-bedded, iine-grained, subangular; some medium grains in lower half; very silty in upper

$0.5 \mathrm{ft} . ;$ lever contact sharp-a 12.1

Coal; basal $0.1 \mathrm{ft}$. includes abundant pyroclastic(?) grains--.

Sandstone, medium-gray, obscurely bedded, very fine grained, subangular, very silty, clayey; abundant ranciom?y oriented carbonacecus plant fragments; few large coalified wood fragments at high angle to bedding---.------ 2 .

Covered intervai-an

Coal; lower contact sharp-a... 1.3 
Siltstone (12f-1 -- upper $0.5 \mathrm{ft.})^{*}$, medium-gray, chunkyweathering, obscurely becded, clayey; many carbonaceous plant fragments; inciudes riear middle 0.5-ft. bed of medium-gray friable very tine to fine-grained sandstone overlain by $0.8-f t$. bed of brownisn-gray very fine grained caroonaceous sanjstone and siltstone;

lower contact concealed in creek-.............................. 4. 


\section{Measured section LI}

Location: Sea-cliff exposures about 1 mile solithwest of Mciveil Canyon in the $\mathrm{NW} 1 / 4 \mathrm{SE} 1 / 4 \mathrm{sec} .26, T .5 \mathrm{~S} ., \mathrm{R} .12 \mathrm{~W}$., Seldovia $\mathrm{C}-4$ quadrangle. This is near locality 142 of Barnes and Cobb (1959, p1. 18).

Feet

Tertiary rocks -- Kenai Group, Be? uga Formation (upper part)

Claystone, medium-gray-and

Coal, shaly; uppemost part of Bed B-C 0.4

Coal- 2.9

Shale, coaly 0.1

Coal-

Shale, coaly- 0.5

Coai, lowest part of Bed $B-14$

Claystone (LiP-28 -- from upper $0.5 \mathrm{ft}$. of unit)*, mediumgray, Tight-gray-weathering, silty; slightly carbonaceous and c:aiy about 1.5 it. below top-............. 9.5

Siltstone, calcareous, concretioracy-a. 0.5

Siltstone, medium-dark-gray, iron-staired, medium-grayweathering, angidiar-fracturing, soit, very clayey-..... 9.5

Sandstone, ligit-gray-weathering, iron-stained, massive, soft, very fine to fine-grained; scattered calcareous concretions-_.

Covered- 6.

Siltstone, iror.: tained, ienticular, calcareous, concreticrary-0. 0.4

Partly covered; nostly dark-gray soft silty claystone-......- 17.5

Siltstone $(\underline{L 1-27)})^{* \star}$, medium-light-gray, platy-bedded, clayey, partiy finely saridy, calcarcous; inciuces few laminae of very tine grained silty sandstone-..........- 0.3

*Palynological sampie

**Lithologicai sampie 
Partly covered; mostly medium-dark-gray soft ciayey siltstone in iower part; harder silty claystone and claystone and ciaystone in upper part............................ 23.

Sandstone $(\underline{L}]-26)^{\star *}$, medium-dark-gray, massive, soft, partly friabie, very fine to fine-grained, stibangular, very clayey; abundant dark rock fragments-_.

Siltstone, medium-dark-gray, massive, soft, clayey, sandy;

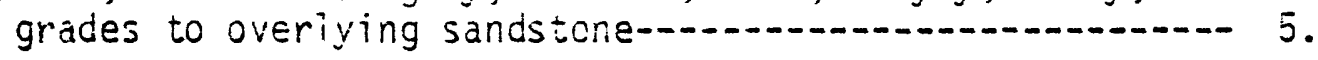

Shale, carbonaceous, coaly-a. 0.3

Claystone, medium-gray-10.-. 0.5

Coal-1- 0.4

Claystone, mediun-gray, silty-a.- 1.7

Shale (LIF-25)*, carbonaceous-_... 0.3

Coal-

Coal and interbedded claystone (LIP-24 -- from claystone)*---- 0.5

Coal $0 . \dot{2}$

Claystone, medium-gray, soft, silty-1...- 3.5

Siltstone, medium-gray, iron-staired, angular-fracturing, very clayey; becomes medilim-dark-gray massive soft

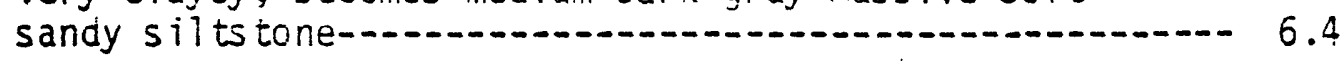

Siltstone, calcareous, concretionary-a..- 1.4

Siltstone $(\underline{L l P-23})^{*}$, dark-gray, thick-bedded, soft-...........- 1.5

Siltstone, dark-gray, massive, soft, clayey; interbedded

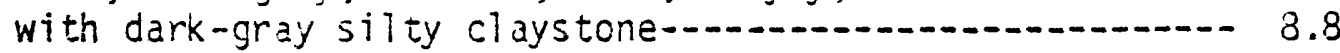

Siltstone (LI-22) ${ }^{* *}$, medium-gray, partly iron-stained, very anguiar-weathering, hackly-fracturing, hard, very ciayey-.....-. 5.8

Siltstone (Li-21)**, nedium-dark-gray, iron-stained, grayish-orange-weathering, clavey, caicareous, concretionary; fEN small carboriaceous piant fragments -.. 0.9

*Palynologicar sampie

$\star \star$ Lithological sample 
Siltstone, medium-dark-gray, iron-stained, vary clayey; includes scattered rounded calcareous concretionary

parts in lower part of unit_-_... 5.5

Claystone ( $L i-2 \mathrm{O}) \star *$, medium-gray, iron-stained, poor platybedded, dominant-angular-fracturing, siity; few carbo-

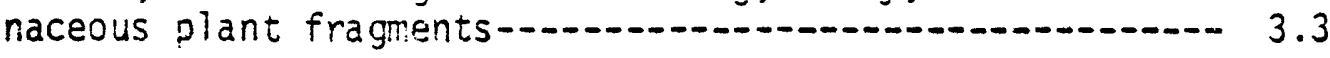

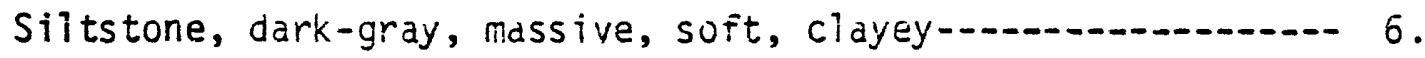

Claystone (LI-19)**, medium-light-gray, compact, very

silty; abundant carbonaceous piant fragments-.........-.-. 1.4

Covered-1.- 6 .

Coal-

Shale $(\underline{\text { LIP }-18})^{*}$, carbonaceous -

Siltstone, medium-dark-gray, ciayey; upper part medium-

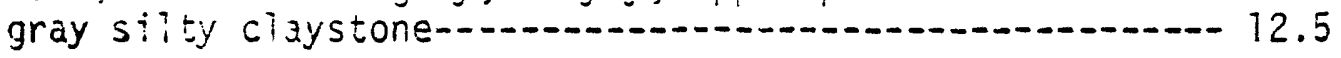

Sandstone $(1 \mathrm{~L}-17) * *$, dark-gray, massive, soft, friable, fine- to redium-grained, subrounced to subangular, silty, slightly clayey; abundant dark rock fragments-_-_- 9.4

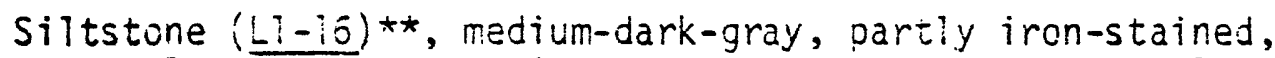
calcareous, concretionary; abundant carbonaceous plant

fragments -......

Coal-_.

Silts tone $(\underline{L P-15}) *$, carbonaceous

Claystore $(L 1-14)^{* *}$, medium-gray, partiy iron-stained,

slight $\bar{y}$ silty; plastic when wet_....................... 0.5

Covered-1-1

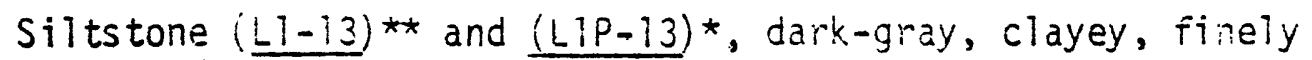

sandy, Carbonaceous

Coal0.2

Partly covered; mostly medium-light-gray massive clayey silts tone-1...

Covered-1.-14.6

*Palynological sample

**ithological sample 
Claystone, dark-gray, light-gray-flaky-weathering, soft-_-.--- 1.4

Claystone $(\underline{1-1-12) * *}$, medium-gray, iron-stained, calcareous, concretionary; abundant iarge carbonaceous plant frag-

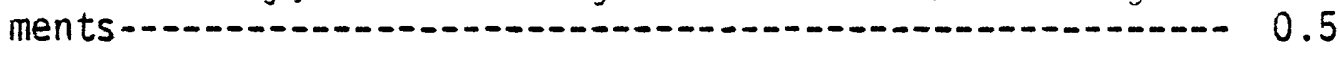

Claystone, medium-gray, light-gray-weathering, compact, silty-1.- 0.4

Shale, carbonaceous - 0.2

Shale, coaly; shaiy coal-_.-. 0.8

Coal, Bad A-1. 2.8

Claystone $(\underline{L I-I 1}$-- from middle of unit) $\star \star ~(L I P-I 1$-- from upper $0.2 \mathrm{ft}$. of $(\mathrm{in} i t)^{\pi}$, dark-gray, party iron-stained, soft, silty; few carbonaceous plant fragments-..........- 3.

Siltstone (L1-i0)**, medium-gray, iron-stained, light-grayweathering, ienticuiar, hard, ciayey, caicareous, concretionary; scattered carbonaceous plant fragments-....-- 0.7

Siltstone $(11-9: * *$, medium-dark-gray, very sandy, ciayey; grades to dark-gray subconcinoidal-fracturing clays ione in upper $2 \mathrm{ft}$.; few carbonaceous plant fragments-...-.-.- 10.6

Coal; includes 50 percent interbecded shaly coal and coaly shaie--1.-1 0.6

Coal- 0.2

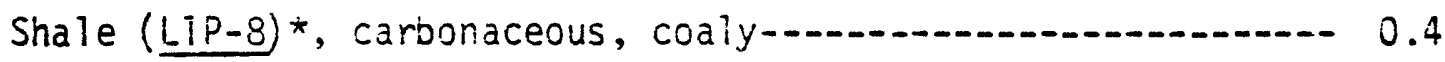

Claystone, medium-dark-gray, light-gray-weathering,

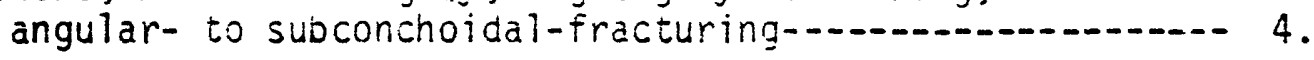

Siltstone $(\underline{(1-7)})^{* *}$, recilum- to medium-1ight-gray, angularfracturing, partly sandy, very ciayey to clayey; abun-

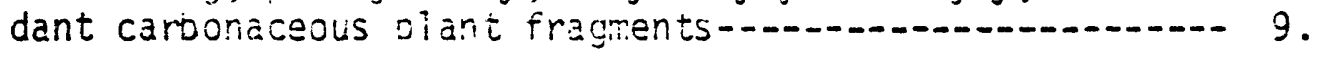

Claystone (L1-0) $* *$, medium-1 ight-gray, light-gray-weathering, angular to subconchoidal-fracturing, hard, silty; scattered carbonaceous plant fragments; interbedded with about 40 percent coal ienses as much as $0.3 \mathrm{ft}$.

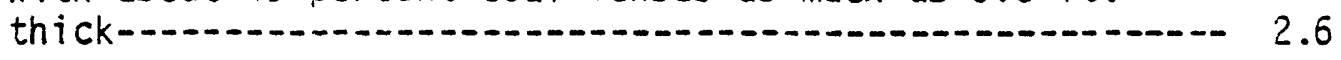

Siltstone, medium-gray, sandy: grades uoward to silty claystone at too-a. sandy: grades woward to sitty *Palynological sancie **ithorogical samole 
Coal, lenticular

Sandstone $(\underline{L l-5) * *}$, dark-gray, horizontally laminated with carbonaceous fragments; very fine to fine-grained, subangular to subrounded, silty, clayey in upper part---- 3.8

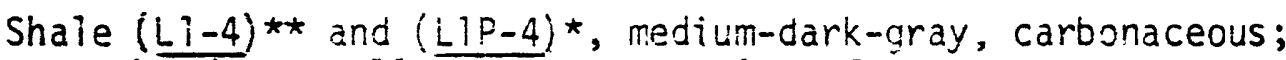
abundant small carbonaceous plant fragments-............- 0.5

Sandstone $\left(\lfloor\mathrm{L}-3)^{* \star}\right.$, light-brown, speckled, yellowish-brownweathering, soit, plastic, fine-grained, subangular, very clayey, volcanic(?) _................................... 0.2

Coal 2.2

Siltstone (LI-2) ** and (LIP-2 -- from upper $0.2 \mathrm{ft}$. of unit)*, medium-gray, partiy iron-stained, very 1 ightgray-weatraring, angular-fracturing, very clayey;

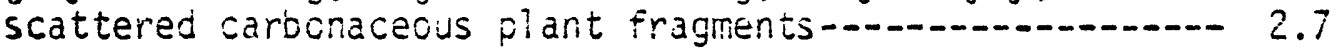

Sandstone (bi-1)**, medium-dark-gray, massive, soft, friable, fine- to redium-grained, siity, ciajey; abundant dark. rock fragments-_- $3.3+$

*Paiynological sample $\star \star$ Lithological sampie 


\section{Measured section L2}

Location: Sea-cliff exposures southwest of MCNeil Canyon in the SE $1 / 4$ NW $1 / 4$ sec. 25, T. $5 \mathrm{~S}$. , R. $12 \mathrm{~N}$., Seldovia $\mathrm{C}-4$ quadrangie. This is near locaitity 143 of Barnes and Cobb (1959, pl. 18).

Feet

Tertiary rocks -- Kenai Group. Beluga Formation (upper part)

Sandstone $(L 2-11) * *(L 2 P-11$-- from near base of unit)*, medium-ligri-gray, partiy iron-stained, vellowish-grayweathering, massive, soft, iriasie, yery fine to finegraired, sibanguiar to sucrounced, clayey; scattered large coaiy fragrents-.......

Coal 0.2

Siltstone, medium-gray, massive, soft, clayey in upper part-_. 4.6

Coal part- 0.9

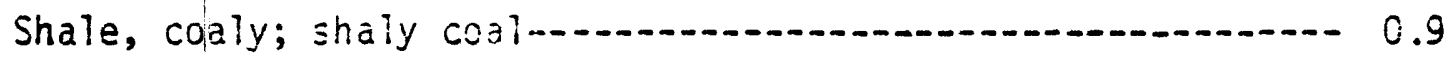

Claystone, carbonaceous - 0.4

Shaie, coain-1... 0.3

Siltstone (L2P-T2 -- from upper part of unit)*, dark-gray, brownisn-gray-weathering, angular-fracturing, sandy in lower part, clayey and caroonaceous in upper part--..- 1.5

Coal, shaly-_. 0.5

Siltstone, medium-gray, iron-stained, angular-fracturing,

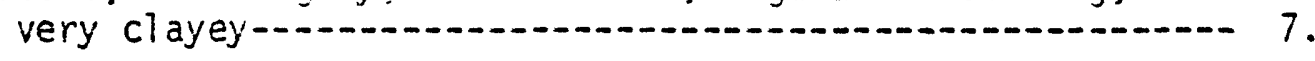

Coal 0.2

Claystone, carbonaceous

Sands tone (L2-g) ${ }^{* *}$, redium-därk-gray, iron-stained, pooriy laminated, angular-fracturing, very fine grained, subangu? ar to storounded, silty and cieyey in upeer part; scattered carbonaceous piant fragments-...........- 10.5

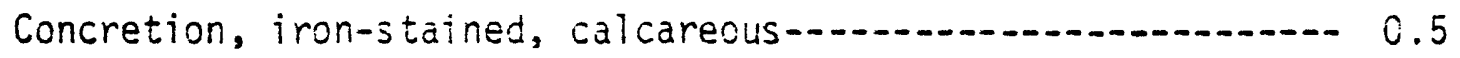
*Palynological semole **Lithological sampie 
Claystone, medium-gray, angular-fracturing, slightiy silty---- 4.1

Sands tone $(12-8) * *$, medium-gray, $y \leq 110$ wish-gray-weathering, thick-bedded, soft, friabie, very fine to fine-graired, subangular, clayey; few carbonaceous plant fragments----- 1.4

Partly covered; mostly medium-grày platy-b@dded very fine grained silty sandstone; incluces feir poorly ceveioped

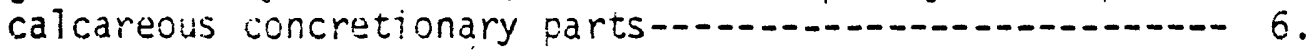

Claystone, yeilowish-brown-weathering, poor placy-bedded,

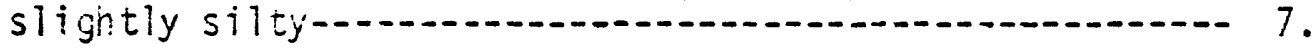

Covered-1.

Shale (L2P-7)*, carboraceous, coaiy; ueper part of Bed D----.- 0.5

Clay (느-6) ${ }^{*}$, gravish-yel ?ow, iron-stained, sott,

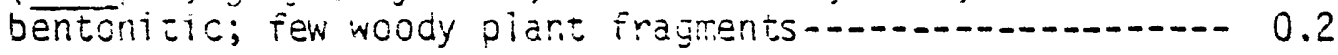

Coal, lowest part of 3 ed $0-1$.

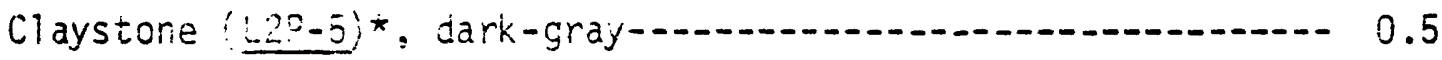

Sandstone (L2-5)**, dark-gray, massive-weathering, poorly cross-laminsted at nigh angle, sot:, iriable, fine- to medium-grained, sudrounced, cialey and very silty in upper part; abundant dark rock iragments-......- 8.9

Claystcre, dark-gray, siity; scatiered calcareo'ss concretions-1-- 13.

Sandstone, yellowish-gray-weathering, rassive, soft, finegrained-1.- 3.

Covered-1.

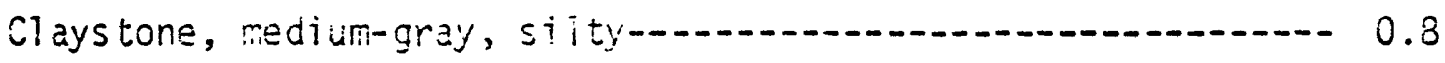

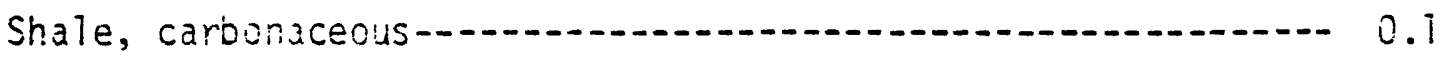

Coal, bed C; includes a lenticulàr 0.3-ft. silty sand-

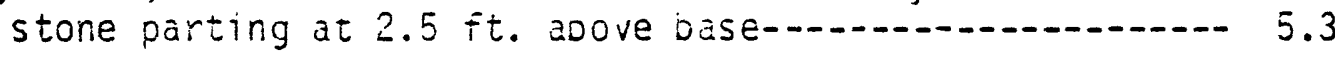

Siltstone (L22-4 -- from uppermost $0.3 \mathrm{ft}$. of unit)*, medium-gray, very clayey; grades to dark-gray silty

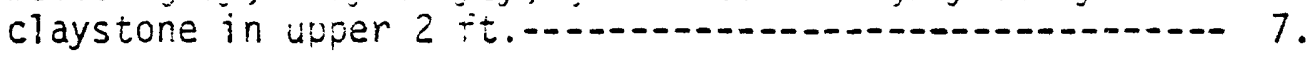

Siltstone, clayey, coaly-_.- 0.3 *Palynological samole **ithological sample 


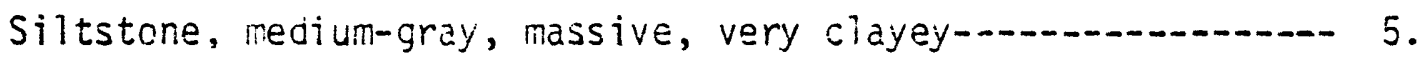

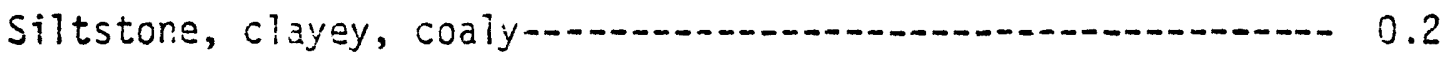

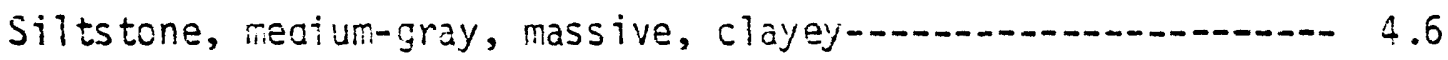

Coal- 0.5

Siltstone. medium-gray, massive, hard, very clayey-.......... 16.

Sandstore (L2-3)**, light-gray, nassive, soft, friable,

fine- to very fine grained, suorounced, si ichtly silty;

abundant dark rock fragments; forms verticaily fiuted

face-1.

Coal

Inaccessib?e; nostiy mediun-1 ight-gray silty claystone--.-.-. 22.

Siltstorie (1-2-2)**, medium-gray, partiy irori-staineo,

light-gray-weatharing, rougr-angular to suconchoidal-

fracturing, hard, sandy, clayey; scattered carbonaceous

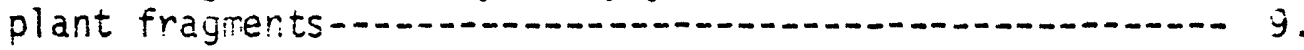

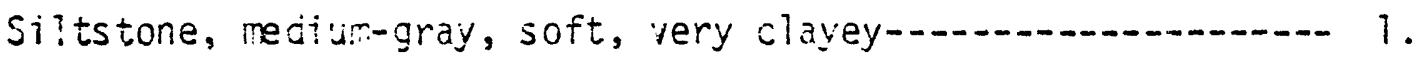

Siltstone, mediuni-gray, laminated ivith abundant carbo-

naceous fragrertis, clayey-1.1 1.7

Sandstone (L2-1)**, redium-dark-gray, thick-bedded, soft,

friable, very firie to fine-grained, subrounced to

subangular, silty to very siity in upper part-..........- 1.5

Siltstore (L2-1)**, medium-light-cray, lamirated to platybedded; very $c^{-}$ayey; tew carbonacsous olant fragments;

scattered lighi-gray cnlcarecus concretions in diper

part-_._-_. 5.7

Covered-a

Top of coal bed 8 
Measured section 13

Location: Sez-cliff exposures northeast of Mcileil Canyon in the SW $1 / 4$ SE 1/4 sec. 24, T. $5 \mathrm{~S}$. , ?. $12 \mathrm{~W}$, Seldovia C-4 quacrangie. This locality is nortneast of locality 140 of sarnes and cobo (i959, p1. 13).

\section{Feet}

Tertiary rocks -- kenai Group. Eeluga Fommation (upper part)

Partiy covered; mostly medium-gray sijty claystone--n-..--.- 5.+

Coal, upeer part of Bad E; includes scattered iron-stained calcareous corcretions as much as 2 ft. lorg in lupper 0.5 ft........... 2

Claystone (L3-ig)**, rediam-gray, i igrit-gray-weathering, partly silty; iounaant smal? carconacecus piant fragments-0.-. 1.2

Coa! $1-0 .-1.3$

Sna?e $(\underline{\lfloor 3 P-18}) *$, carbonaceous- 0.3

Coal, lower part of Bed E- 0.5

Ciaystone (L3P-17)*, rnedium-gray, siity-

Sandstone, meaium-gray, thick-bedded, soft, fine- to very fine grairea, silizy-n 2.7

Mostly covered; lower part of unit mostly medium-gray clayey siltstone; uocer part mostiy medium-gray rassive soft sandstone; iew Ecattered irsn-stained calcareous coricretions in lower part-... 33.

Coal 0.8

Claystone, medium-gray, i ignt-gray-weatrering, angular-

fracturing-- 4.7

Coal 0.4

Claystone, medium-gray, light-gray-weathering-_... 1.4

Coai 
Partiy covered; lower part mostly soft siightiy cartoraceous ciaystore; upper part mostly clayey siltstone-_........ 13.3

Coal-

Ciaystone $\left(L_{3-15}\right)^{* *}$, medium-gray, i ight-gray-weathering,

hard, silty, slightly carconaceous; scattered carbo-

naceous plant fragments-(- 0.9

Coal-

Claystore $(\underline{3 P}-15)^{*}$, carbonaceous; includes few iaminae

of sandstone-... 0.2

Coal

0.2

Sandstone, medium-gray, angular-fracturing, very silty,

clayey--

Sandstone, medium-gray, iron-stained, yeilowish-brown-

weatharing, inassive, soft in lower zart, siity, ciayej;

grades upuard to harder less silty and ilayey sandstone

with large caroonaceous plant fragments--....

Coal and carbonaceous shale (L3P-14)*

Claystone, medium-gray, slightly carionaceous-_........ 0.3

Coal-1-20. 1.2

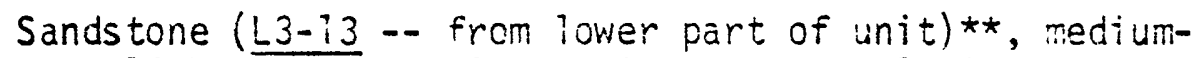

light-gray, rostly massive out some laminae and cross-

laminae shown by carbonaceous fragments, soft, friable,

fine- to very fine grainea, subanguiar, ciayey; in-

ciludes few interbeds of medium-gray clayey siltstone

and carbonaceous parts $0.5-0.2$ Ft. thick; clayey in

upper $5 \mathrm{ft}$.

$20 . i$

Siitstcne, redium-light-gray, anguiar-fracturing, sandy,

clayey; pocrly develoced joirt system at $30-60$

degrees to norizontal-... 6.

Coal

Coal and shaly coal (L3P-12)*; some interbedded medium-

gray claystone-1 0.3

*Palynological sample

** Li thological sample 
Claystone $(3-11)^{* *}, 1$ ignt-brown, grayish-yellow-weathering, soft, piastic, tentonitic; abundaric carooraceous plant

fragments - 0.1

Claystone, nedium-gray, slightly carbonaceous-_... 0.1

Coal- 0.6

Sandstore, redium-oray to medium-iignt-gray, clayay and

silty in lppei part-_. 4

Siltstone, medium-grey, anguiar-fracturing, ciayey-n...... 4.

Sandstone, rediur-gray, massive, sore Taminaticn and cross-

iamination snviur oy caroonazecus plart fraguents,

soft, silty; incerbedied witn ajout 20 vercent slightly

more resistant i arinated clayey siity saridstone-....... 5.

Sandstore $(1-3-10) x *$, medium-1ight-gray, partly iron-stained,

iaminazed and cross-iaminated at iow angles snown oy

carbonaceous olant fragments, sott, very fine grained,

subangular, siitj, clavey- 15.8

Claystone (L3P-9)*, redium.gray, carbonaceous-_........... 0.3

Sandstone (i-j-8)x+, medium-dark-gray, massive, soft,

friable, rostiy vary fine crairej, subanguiar to sub-

roundea, claysy and silty in ufper part; abundant

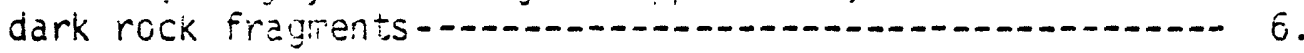

Siltstore, mediun-gray, angular-fracturing, very clayey--.--- 6.9

Sandstone, meaium-dark-gray, massive-weathering, lami-

nated and cross-iaminated with carbonaceous plant

fragments, soft, isry fine to irie-grainad-......... 3.6

Siltstone, redium-gray, angilar-fracturing, very ciayey-....- 1.5

Coal, shaly- 0.2

Siltstone, redium-gray, partily iaminated and cross-

laminated witn carionaceous olant fragrents,

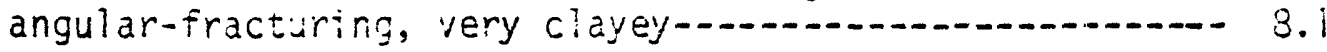

Clay (L3P-7)*, carbonaceous, coaly

Siltstone, dark-gray, iaminated and cross-laminatad

with carbonaceolis plant fragments, clayey-n... 2.5

*Palynological samoie

**Lithological sample 
Sandstone $(-3-5)^{<*}$, medium-dark-gray, iron-stained, hard, very fine grained, subangid! ar, carbonaceous, semiconcretionary, ciayey, silty; scattered sma!l varoonaceous plant fragments-...... 0.3

Siltstone, dark-gray, massive-iveathering, laminated and cross-laminated witn carbonaceous plant fragments, very clayey-1 0.8

Covered-1. 1.4

Partly covered; mostly medium-light-gay angularfracturing very ciayey siitstone-1... 7.

Shale, coziy, carbonaceous 0.1

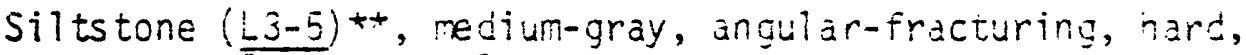
very clayey, partly sandy; scattered carbonaceous fragments - p.........

Sandstone (L3-4)**, medium-light-gray, yeliowish-grayweathering, thick-bedded, sott, friabie, very fine to fine-grained, subangular, sligntly clayey-......... 2.4

Sandstone $($ L3-3)**, medium-light-gray, yellcwish-orownweathering, iamirated and cross-lamirated, very fine grained, sucangular, ciayey, silty, slightiy caicareous; nore resistant than overiying and underlying units_... 0.6

Sands tore, medium-1ight-gray, grayisin-yellow-weathering,

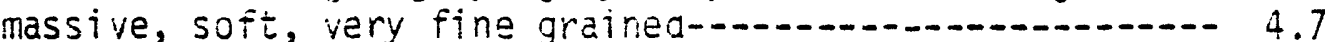

Sandstore $(L 3-2){ }^{\star *}$, nedium-1i gint-gray, partly iron-

stained, yei i gish-bronn-vie thering, iaminated, very

fine graired, suoangular, sil ty, ciayey; few carbo-

nacaous piant fragments; more resistant than over-

lying and underlying units-... 0.4

Sandstore, redium-iignt-gray, grayish-yellow-weathering, miassive, soft, very fine grained-_.......

Concretion, iron-stained, caicareous-... 0.4

Claystone, medium-gray, poor platy-bedded, slightly cartonaceous -

Coal, Bed D-1

** Lithological sample 
Siltstone ( $\underline{L 3-1}$ and $\underline{L 3 f-1}$-- from ucper $0.8 \mathrm{ft}$. of unit)** * dark-gray, very Glayey; scattered caroonaceous piant fragments -

$3 .+$ 


\section{Measured section L4}

Location: Sea-cliff exposure west of Eastland Creek in the SiN $1 / 7$ SW $1 / 4$ sec. 9 and SE $1 / 4$ SE 1/4 Sec. B, T. 5 S., R. 1? W., Seldovia D-4 quadrangie. Fis is near locality 157 of Barnes and Cobb (1959, pls. 13, 19).

Tertiary rocks -- Kenai Group, Sterling Formaticri

Feet

Claystone, light-gray-ueathering, roctangul ar-fracturing, silty

Coal, Shaly; upper part of Bed G- 0.4

Codil-

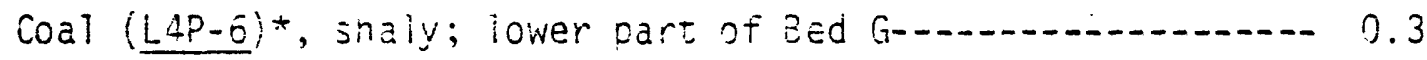

Claystone, "eitur-gray, angular-iracturing, silty in lower part, caroonaceous in upper part-...... 2.2

Partly covered; mostly yeliowish-gray-weathering clayey

sil tstore-

Concretion, iron-staired, caicareous-1. 0.7

$\operatorname{Coa} 1$

0.3

Claystone (1-5 - trom upoer Dart of unit)**, mediur-eray, iron-staines. graysish-orown-wedthering, sandy, sitiv; abundant carbonaceous iracmenzs; inciuces coal ienses as much as 0.3 ft. Lnck; scattered iron-stained caicareous concretions -....... 7.3

Sandstone, medium-gray, massive, soft, very fine to fine-grained, silty; interbedded with about 50 percent medium-gray

silts tone-....... 4.3

Siltstone, medium-gray, angular-fracturing, very clayay-.-.- 4.5

Sandstone, redium-gray. Tassi'je. soit, very fine to fine-

grained-_..

Beluga Formation (upper part)

Claystone, medium-dark-gray, iron-stained, mostiy angular-

fracturing, partij poorly laminated-... 3.6

Coal-

*Palynologicai sample

** Lithological sample 


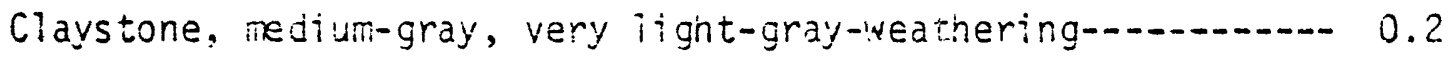

Coal-

Partly covered; mostiy silty claystone, especialiy in usper part-1... 3

Claystone, very carbonaceous; less carbonacecus in upper

part-. 0.7

Coal, upper part of bed F- 0.8

Claystone, mediur-dark-gray, sligntiy carbonaceous-_....... 0.7

Coal, shaly

Shale $(\underline{L 4 P-3)})^{*}$, carbcraceous-

Coal, lower part of Bed F- 1.7

Siltstorie ( $14-2$-- from woper 0.3 ft. of unit)**, medium:-

dark-gray, li gint-gray-ieatnering, massive, soit, vary

clayey; scattered carbonareous plant iragments; in-

cludes two coajy lenses, $0.2 \mathrm{ft}$. thick, at 5 it. above

base and $3 \mathrm{ft}$. bei $\mathrm{icw}$ top-... 16.

Coal $1-20.5$

Ciaystone, medium-gray, si ity-1 0.7

Coal-

Claystone, medium-gray, silty; includes a 0.4-ft. coal

lense at 1.2 ft. beiow top- 3.3

Concretion, iron-stained, salcareouis-a. 0.9

Claystone, medium-gray, angijar-fracturing, sility-_.......- 10.3

Shale, coaly; Lipper part of Bej E-.. 0.2

Coal- 10.9

Shale, carbonacecus- 0.4

Coal

Claystone $(\underline{1}-4 \mathrm{P}-1) *$, carbonaceous - 0.4 *Palynological sample

**Lithological sample 
Coal, lower part of Bed E-_....... 0.2

Claystone, silty, carbonaceous-a. 0.3

Claystone, yellowish-gray to yellowish-brown, iron-

stained, angilar-fracturing, siity, siightly

carbonaceolis

$0.5+$ 
Measured section $L 5$

Location: Sea-cilff northeast of Falis Creek in the MUE $1 / 4$ SE $1 / 4 \mathrm{sec}$. 3, T. 5 S., R. 11 i.., Seldovia 0-3 duacrangle. This is locality 161 of Barnes and Cuob $(1959$, pis. 13, i9).

Feet

Tertiary rocks -- Kenai Group, Sterling Formation

Base of lowest bench of coal bed $k$

Sandstone, medium-gray, light-gray-wejthering, massive,

soft, silty in upeer part; doundant caroonaceous olant.

fragments in loper part-.................................

Claystone, 1 ight-gray-weathering, angular- to conchoidal-

fracturing, sligntly carbonaceous....................... 0.4

Coal 0.3

Claystone (15-23)*x, redium-1ight-gray, partly iron-stained,

light-gray-weathering, conchoical-fracturing, nard;

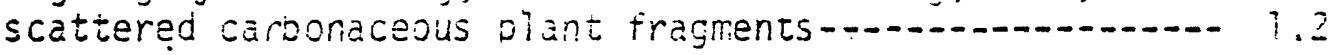

Claystone, redium-gray; inciudes lenticular coal laminae-....- 0.4

Coal

0.3

Siltstone, medium-gray, lignt-gray-weathering, angular-

fracturing at nign angles to top and sottom of unit,

partly clayey-1-1 11.5

Coat

Siltstore, rediun-dark-gray, ilgnt-grav-weathering, anguiärfracturing along vertical jianes or along planes at 30

degrees to top and bottoin of unit_......................... 12.

Silts tone, carbcnaceous -

Siltstone, simiar to 12.7-ft. unit above-....................... 0

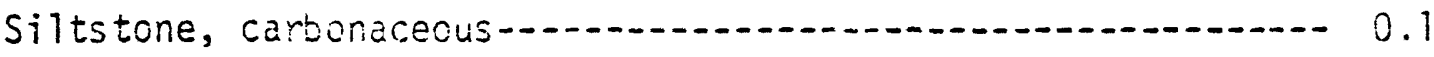

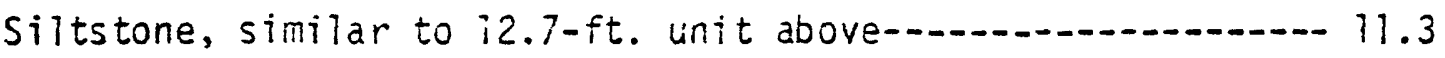

** Lithological sample 
Siltstone, medium-dark-gray, angular-fracturing, clayey;

interbedded with about 20 jersent siit:y llaystone and

lentils of very fine grainea silty sanjstone; szattered

ironstone concretions asout $0 . \overline{f t}$. thick by $1 \mathrm{ft}$.

long at $2 \mathrm{ft}$. beiow top-. 20

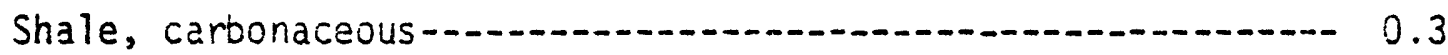

Coal- 0.8

Sandstone, redilim-dark-gray, massive, partly angular-

fracturing, soft, very fine grained, silty; inter-

bedded with meaium-gray angular-fractiring clayey

siltstone-1.

Siltstone (15-2?)**, meoium-gray, carbonaceous; inter-

bedded witn sligntly carbonaceous si ity nicaceous

claystone and silty very iine gratred subanguiar

sands tone-1.9

Partly covered; mos $I l y$ medium-gray ( 1 ight-qray-weathering)

poor platy-beddea sility olustone; sore ironstone

concretions about 0.2 ft. snick and $0.5 \mathrm{ft}$. iong

at $2.5 \mathrm{ft}$. below top- 11.5

Claystone, medium-gray, soft, very silty-a. 0.5

Coal, shaly; ucpermost part of ged $\mathrm{J}$; along strike unit

becomes coaly snaie with calcareous concretions in

places-0. 0.8

Coal-

Shale, carbonaceous-a. 0.7

Coal-1 0.5

Sandstone (15-2! -- from uoper cart)**, madium-dark-gray, thick bedded, soft, friable. very fine to fine-grained, subangular to subroinded, sil $1 \%$, very carbonaceous in upper part; abundant carsonaceolis plant fragments-...-.- 1.6

Coal 0.2

Shale, carbonaceous-a.n 0.8

Coal, lowest part of Bed J-1 ** Lithological sample 
Siltstone (L5P-20 -- from upper $0.6 \mathrm{ft}$. of unit)*, lightgray-p Taty-weatnering, platy-bedded, sandy; abunciant carbonaceous piant fragrents; grades rapidly downward to silty sandstone in iower part_........................ 2.2

Partly covered; mostly clayey siltstone-1..................... 5.

Sandstone, vellowish-brown-weathering, massive, soft, very fine grained; interbezded wi th about 50 percent silty claystons and clayay silts tone in beds 0.5-2 ft. thick-1....... 11.5

Claystore, medium-dark-gray, platy-bedded, silty-............. 1.9

Note: The becding in the claystone units is generally more obvious in this and lower jerts of the stratigraphic sequence than in the parts stratigraphically nigher.

Sandstone, yei iowish-trown-weathering, thin-bedded, soft,

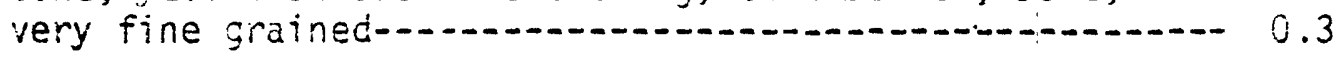

Claystore, medium-dark-gray, platy-iedded, very silty-......-. 2 .

Codl, shaly-. 0.3

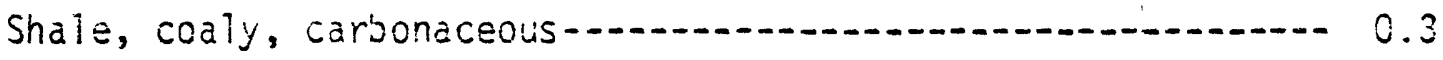

Coal- 0.2

Siltstone, medium-dark-gray, light-gray-weathering, anguiar-

fracturing, very clayey; includes a poorly deveioded

calcareous ccncretion ( $0.5 \mathrm{ft}$. Dy $3 \mathrm{ft}$.) about $4 \mathrm{ft}$.

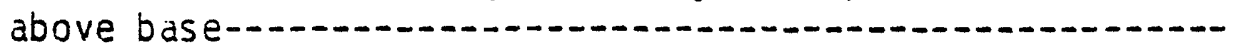

7.5

Sands tone, yellowish-brown-weathering, thin-bedded, soft,

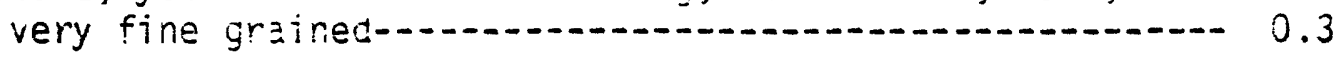

Siltstone, medium-dark-gray, angular-fracturing, ciayey-...-.- 2.

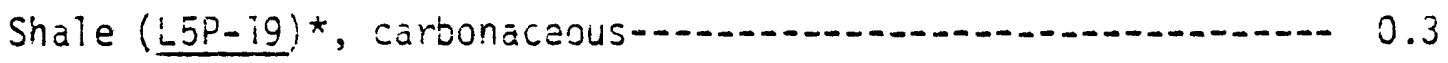

Coal

Shale, carbonaceous-a. 0.5

Coat- 0.1

Shate, coaly-and 0.2 *Palynological sample 
Sandstone, dark-gray, vell owish-brown-weathering, medium-

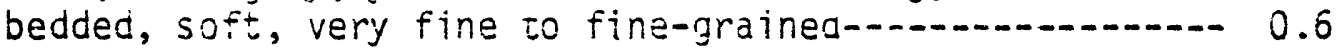

Siltstone, redium-gray, poor platy-bedded, sandy-_........ 1.5

Sandstone, ye llowish-brown-weathering, in in-jedded, scit, very fine grained-_. 0.4

Siltstone, medium-gray, soft, very llayey-1.

Shaie, coaly- 0.4

Coal

Shale, coaly; shaly coal- 0.3

Coal

Claystone $(15-18)+(15 P-18--$ from upper $0.5 \mathrm{ft})$.$* , redium-$ gray, ignt-gray-wea-nering, inguiar-fracturing, very silty, carbonaieous in upper J.j ft.; scattered cardonaceous piant iragments-1... 3.8

Sandstone, medium-gray, thin-bedded, soft, very fine to finegrained, si ity, clayey- 0.3

Siltstone, madiuir-dark-gray, angular-fracturirig, soit, clayey-......

Claystone, medium-gray, angular-fracturing, soft, silty--..-- 3 .

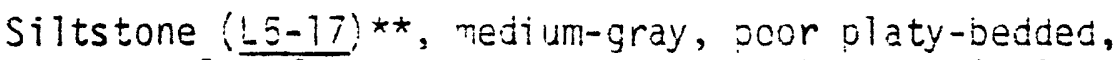
anguiar-fracturing, soit, very clayey, fireiy sandy;

few scattered carbonaceous plant fragments-.......... 2.5

Coal (LSP-io -- from upper 0.1 it. of unit)*, shaly; upper part of Bed I........ 0.6

Coal, lower part of sed I- 1.6

Siltstone, medium-gray, angular-fracturing, soft, very

cl ayey-1.6

Claystone (L5P-15)*, carbonaceous-

Coal- 0.1

*Palynological sample

**Lithological sampie 


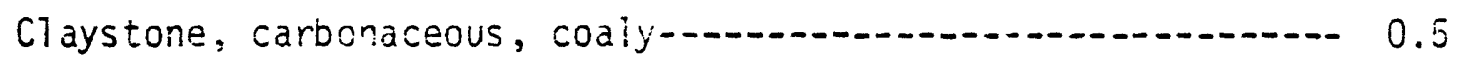

Claystone, medium-light-gray, anguiar-fracturing, silty-...-.- 0.4

Covered-1-20-1 30.

Claystone, medium-gray, angular-fracturing, very silty-...-.-. 7.

Coai, shaly-1y 0.4

Coal-1-

Shate, coaiy-a. 0.9

Shate, carbonaceous-1... 0.2

Siitstone, medium-gray, angular-fracturing, very ciayey-...-.- 1.1

Claystone, medium-gray, light-gray-weathering, anguiar-

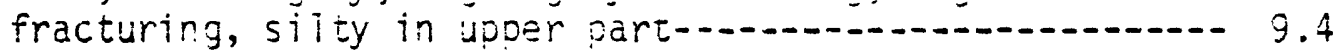

Sarids tone, medium-dark-gray, medium-bedded, soft, very

fine to fine-grained-_..... 0.7

Shale, carbonaceous-a.-. 0.3

Coal- 0.2

Shale, coaly-1. 0.5

Coal- 0.6

Coal, shaty-1. 0.4

Shale, coaly, carbonaceous-1 0.3

Shale, very coaly-1.3

Claystone $(L 5-14--$ from lower part of unit)** (LSP-T:4 -

from upper 0.4-fi. of unit)*, redium-und ilgrt-

gray-weatherirg, angular-fracturing, silty, caroo-

naceous in uposer 0.4 ft.; Felw zarbonaceous plant

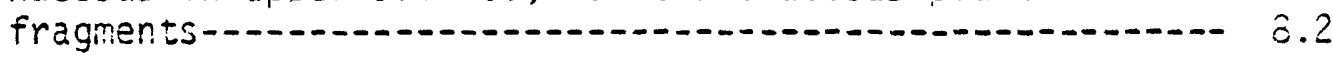

Covered-1.

Sandstone, medium-i ight-gray, thick-becded, suft, very

fine to fine-grained-- 2.

*Palynological sample

$\star *$ Lithological sample 
Claystone, medium-gray, light-gray-weathering, angular-

fracturing, sility-.. 2.5

Sandstone $(\underline{L 5-13})^{* *}$, medium-1ight-gray, yellowish-brownweathering, medium-bedded, soft, very fine to fine-

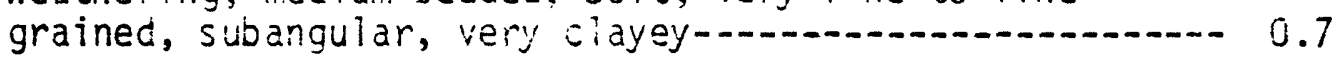

Partly covered (L5-12) ${ }^{* *}$; mostly medium-grav very clayey

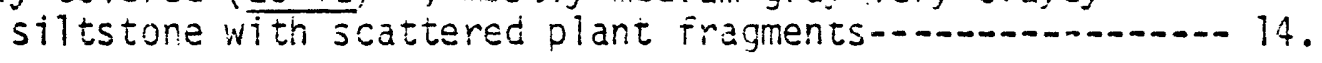

Claystone, medium-dark-gray, light-gray-weathering, angular-fracturing-_. 6 .

Coal; includes a lenticular 0.1-ft. claystone parting 0.2 ft. above base-1. 2.7

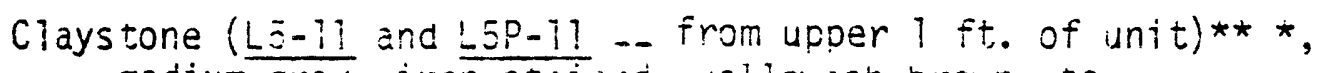
medium-gray, iron-stained, jellowish-brown- to grayish-yel low-weathering, cough, compact, slightly

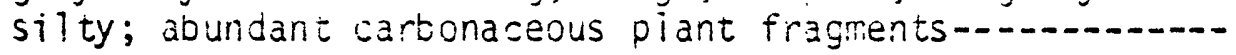

Covered

Partiy covered (L5-10)**; lower part medium-gray artiy iron-stained sandy clayey silistone; upper part rediumgray massive sott friatle very fine grained sicangular silty sardstone-..... 4

Partly covered; mostiy vellowisn-orown- to gravish-yellowweathering, iassive, sott sandstore, lpper part silty--.- 0.

Sandstone $(L 5-9) * *$, medium-gray, grayish-yellow- to yeilowishbrown-weatnering massive soft, friable, very fine to fine-grainad, subangular to sliorounded-... 13.

Coal $(\underline{L P}-8) *$, shaly-n 0.1

Coal 10.8

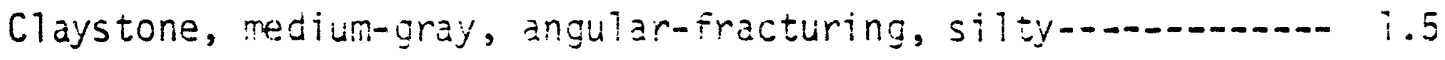

Covered-0.

Coal

Shale, carbonaceous 0.3

Coal, Bed G- 1.3

*Palynological sample **Lithological sample 
Coal $(\mathrm{LEP}-7){ }^{*}$, sha? $\mathrm{y}-\ldots$

Claystone (L5-6)**, medium-dark-gray, yeilowish-brownweatherirg, silty; few caroonaceous plant fragments; interbedded with medium-gray iriable very fine grained

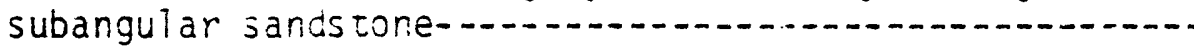

Coai, snaly0.4

Siltstone, medium-gray, sandy, ciayey; scattered coaiy

lenses less tran 0.2 ft. inick; interbedded with a few beds, less than 1 it. thick, of medium-gray soft sandstone: lower contact gradationai

Sands tore $\left(\lfloor 5-5)^{* *}\right.$, medium-gray, yell owish-uray-weathering, massive, soft, friable, very fine to fine-crained, partly fine- to nedium-graires with cross-oeoded lentils of coarser material, rare peodles, and some rounded clay masses, susrounded to subinguiar, si?ty; unit generaliy finer grained lipward; ocld cilif-former........ 30

Beluga Formation (upper part)

Coal, upper berch of Bed F

Siltstone, mediur-gray, very i ight-gray-weathering, partly

laminated with carbonacecus piant material. piaty-

fracturing at about 30 degrees to top and base of unit, sandy-1..-

Sandstone (L-1)**, medium-dark-gray, thick-becded, soit, friable, fine- to mediuri-gra ined, subrounded, partly

clayey; abundant dark rock fragrents..................... 1.9

Siltstone $(\underline{50.3})^{*}$, nedium-dark-gray, clayey near base,

sandy near top- -......... 1.7

Shale, carbonaceous-1.... 0.3

Coal, middle bench of Bed F.......... 0.9

Claystone (L5-2)** , medilum-dark-oray, hard, compact, yery

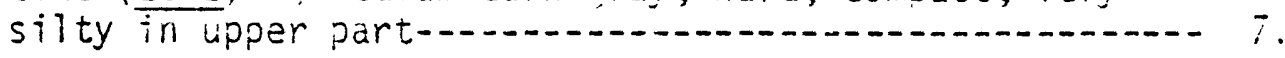

Shale, carbonaceous-1............. 0.3

Coal, lower bench of Bed F-a.

Clays tone, redium-dark-gray, 1 ight-gray-weathering, angular-fracturing-_... 2.

*Palynological sample

$\star \star$ Lithological sample 
Coal

0.5

Claystone (L5-I)**, medium-dark-gray, i ight-gray-weather-

ing, anguilar-fracturing, hard; scme subhorizontal

lamination shown by cárbonaceous plaric frägments-...-...-- 2.+ 
Measured section L5

Location: Stream-bed and canyon-wall exposures in unnamed canyon in the SE $1 / 4$ iv $1 / 4 \mathrm{sec}$. 36, T. 4 S., R. IT $\mathrm{N}$. , Seicicia D-3 quadrangle. This is locality 160 of Barnes and Cobb $(1959$, pls. 18 , 19).

Feet

Tertiary rocks -- Kenai Group, Sterling Formation

Partiy covered ( $15-15$ and $L 6 P-15$-- from upder $5 \mathrm{ft}$. of

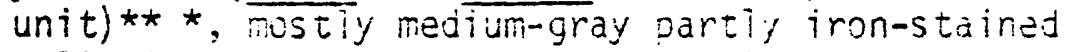
yellowish-brown-weathering sandy clayey siltstone that braaks to angular coobies and pebbles; abuncant carbonacecus piant iragments; interbedded with about 25 percent sandstone similar to underlying unit; includes a $0.1-\mathrm{f} \tau$. coal $(\underline{\mathrm{LEF}-14}) *$ at $19 \mathrm{ft}$. above base-...- 30 .

Sandstone, yellawish-orowri-weathering, soor platy-bedded, partiy horizontally laminated with carbonaceous plant fragments, mostiy very fine grained; breaks to

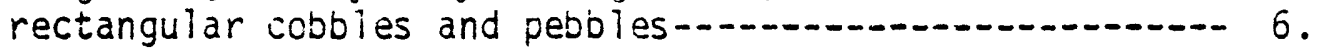

Covered-10. 5.

Sands tone, yel lowish-brown-weathering, Diaty-bedded, soft, very fine to fine-grained-_... 0.3

Coal; burned in places-a. 2.2

Sandstone, light-gray-weathering, partly iron-stained, laminated with carbonaceous piant iragments, very

fine grained, silty in upper part-a... 4.2

Claystone, slightiy carbonaceous in lower part, silty and sandy in upper part-a. 2.9

Coal 0.6

Shale, coaly- 0.1

Coal and shaily coal-a. 0.3

Claystone, carbonaceous

Coal

*Palynological sample ** Lithological sample 
Siltstone, medium-dark-aray, poorly laminaten to coor platy-bedded, very clayey; breaks to angular pebbles

Claystone (1.6-13)**, medium-brown, brown ish-gray-weathering, hard, clayey, partly carbonaceous; fow carbonaceous plant fragments; scatcered pyroclastic(?) grains-----1.--

Shale, carbonacecis; interbedded with shaly coal and coai-...- 0.8 Siltstone, medium-dark-gray, sitgntiy carbonaceuus-..........- 2.5

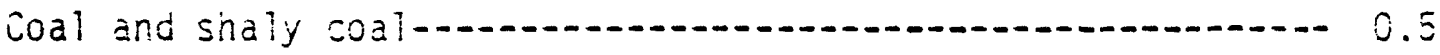

Claystone, mecium-iight-gray, ii gnt-gray-weachering, flaky, partly carbonzceous--.-.-.-. 0.9

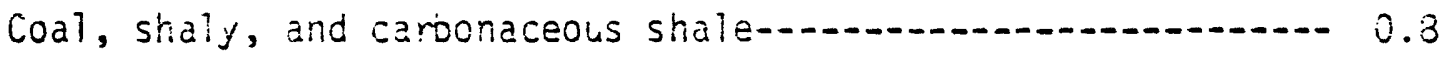

Claystone, carbonaceous

Shale, coaiy-a.t

Coal-

Siltstone $(16-i 1) * *$, i girt-orown, brownish-gray-weathering, hard, clayey, partiy caroonaceols; abundant caroonaceous plant fragments; scatterec wnite pyrociasticl?! grains---1

Coat 0.8

Partly covered: about 50 percent yellowish-gray-weathering fine-grained sanastone; rest of unit iight-grayweathering silus cone; $i-f t$. carbonaceous silits tone at top-1.-...- 6.5

Shale, carbonaceous, coaly-an

Coal-1. 0.5

Claystone (15-10)**, medium-1ight-gray, light-gray to yellowish-gray-wedinering, hard, partly silty; weathers rounded in places but breaks to angular cobbles arid peboles in other piaces; abundant carbonaceous plant fragments-....- 3.

Sandstone, grayish-yellow-weathering, partly iron-stained, medium-bedded, soft-_......... 0.6 ** Lithological sample 
Siltstone ( $: 6-9)^{* *}$, redium-gray, i git-gray-weathering, poor platy-bedded, soft, olayey, finely sandy; few

carbonaceous plant fragments-.............................. 5

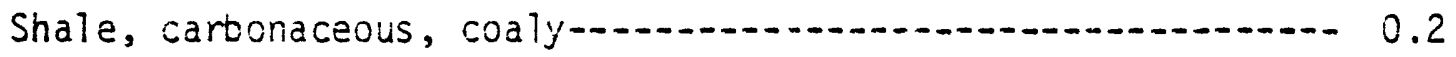

Coal- 0.5

Claystone, medium-dark-gray, !ight-gray-weathering, poor

platy-bedded, si?ty; abundant carbonaceous plent

fragments--- 1.4

Coal-

Siltstone, medium-dark-gray, itght-gray-weathering, ooor

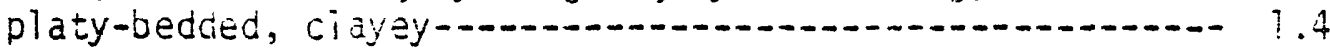

Sandstone, medium-gray, grayish-yellow-weathering, thick-

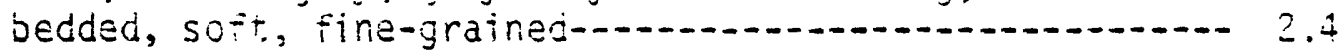

Claystone, iight-gray-weathering, coor platy-bedded, very siliy; sitightly caroonaceous in iuwer i ft.........- 5.

Sandstone, medium-gray, medium-bedded, soft, fine-

grained--..- 0.6

Claystone $(10-8) * *$, recium-gray, very i ight-gray-roundedweathering, poor piatv-bedded, hard, partly silty;

few small carounaceous diart iragments-.................- 3.5

Sandstone, medium-gray, iron-stained, yellowish-grayweathering, poor platy-bedded, very fine grained,

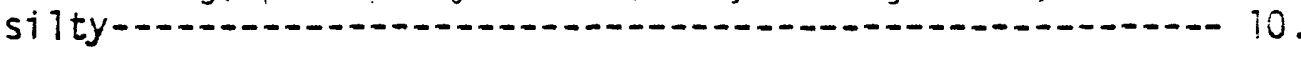

Sands tone, medium-gray, yeliowish-gray-weathering, massive,

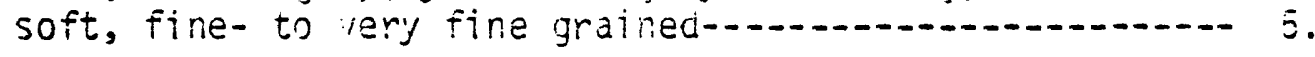

Sands tone, nediur.-gray, vely iron stained, laminated with abundant carocnaceous olant fragments, massive, soft, very fine to fine-grained-.................................. 8

Sandstone (L5-7) $)^{*+}$, edium-gray, iron-stained, yellowishgray-weatiering, massive, soft, friable, mostly finegrained, sicroiriced to subanaular, silty; some crossTaminations of cartoraceous fagrients at argles of 10-25 degrees-....... 17.5

Siltstone, medium-dark-gray, light-gray-weathering, platybedded--.--1.-1 4.3

**Lithological sample 
Sandstone, medium-gray, very iron-staired, yellowishbrown-weathering, chick-bedded, soft, ros 51 y finegrained-1.2

Silistone, redium-dark-gray, iight-gray-fiaky- to platyweathering, platy-bedded, very clayey-..................... 10.

Covered-a

Claystone, medium-dark-gray, carbonaceous-........................ 2.

Coal, Bed M-1

Siltstore, light-gray-weathering to hard angular jiocks and platy pieces, platy-becded, very sandy in part--.-.-.- 5.5

Coal and shaiy coai

Silts tone, redium-gray, licht-gray-weathering, breaks to

hard rounded pieces; scattered carbonaceous fragments--.- 2.4

Sardstone, medium-gray, yeinowish-gray-weatnering, massive

to poorly laminated in upper $2 \mathrm{ft}$., soft_.................... 9.3

Siltstone, medium-gray, iight-gray-weathering, poor platybedded-_........ 6.8

Sandstone, medium-gray, yeilowisn-brown-weathering, 1 aminated with carjonaceous piant fragments-................... 2

Siltstone, medilim-gray, 1ight-gray-weathering, very clayey; interbedded with redium-cark-gray (1 ignt-gray-weather-

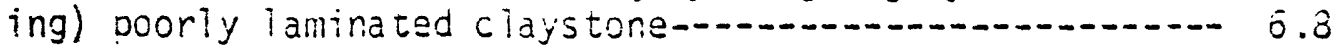

Coaly shale and shaly coal

Sil ts tone, medium-gray, light-gray-weathering-_................ 4.7

Sandstone, mediun-gray, i ight-gray- to grayish-orangeweathering, massive. soft, very fine to fine-grained,

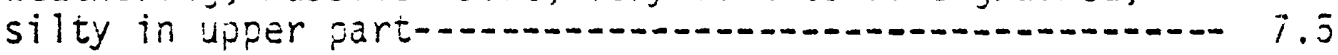

Claystone, medi um-gray, light-gray-platy-weathering, pocrly

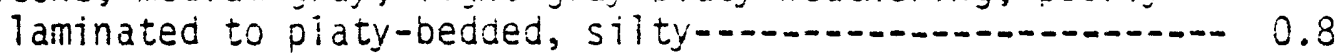

Coal, shaly-a. 0.8

Shale $(\underline{16 P-6})^{*}$, coaly

*Palynological sampie 
Claystone, dark-gray, light-grav-weathering, pcor platybedded, silty; interbedded with about so percent yellowish-gray-weathering soft very fine to finegrained sandstone in beds asout $0.2 \mathrm{ft}$. thick-........... 29.2

Coal

Siltstone, medium-gray, light-gray- to browrish-grayweathering, breaks to anguiar flakes and jebble-size chunks, poorly laminated, very clayey-.................... 13.

Siltstone, coaly, cartonacecus-a. 0.2

Siltstone, redium-dark-gray, breaks to angular petblesized chunks, cooriy laininated to poor platy-bedded, sandy in lower part, clayey in upoer part_................. 7.2

Partly covered; mostly yellowish-gray-weathering very fine grained sands tone and i ght-gray-weatrering

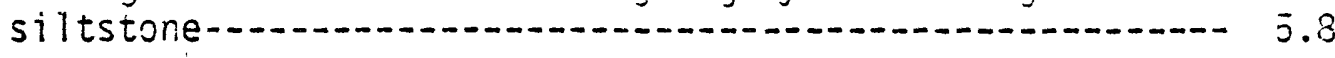

Coal and shaily coal-1.

Shale, carconacecus, ccaiy-1. 0.3

Coal-1

Siltstone, light-gray-weatherina, angular-fracturing,

clayej; scatzered iron-stained calcareols concretions

in upper part-a.-. 5.5

Sandstone, mediurn-gray, thick-bedded, soft, fine-grained--.-.-- 1.4

Coal, shaly-a 0.3

Siltstone, redium-gray, clayey; includes coaly streak

$0.4 \mathrm{ft}$. below top-1

Sandstone $(\underline{6-5}) \star \star$, mediun-gray, very iron stained, yellowishbrown-weatnering, friabie, ine- to very fine grained, subangular to sutrounded, si ity in uooer part; : aminated with caroonaceous plant fragments-..................

Claystone, iight-gray-weathering, poor platy-bedded, very

si 1 ty--

Coal and shaly coal-a 0.3 
Siltstone, nedium-dark-gray, light-gray-weathering,

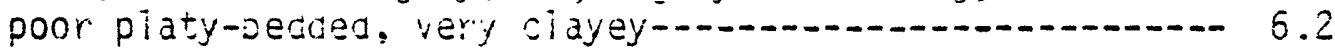

CoaT-10 0.7

Shaie, coaly-...... 0.2

Sandstore, medium-gray, medium-beaded, soft, mostiy finegrained, silty-1

Covered-1.- 8.

Siltstone (L6-1)**, redium-gray, cartly iron-staired,

light-gray-weathering; oreaks to anguiar fizkes ard

pebble-sized dieces, very clayey; abundant caroo-

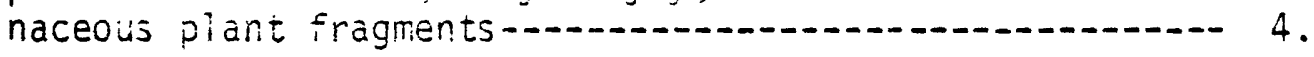

Sandstone (10-3 -- from lower part of unit)**, medium-darkgray, nassive to obscurely sedded, joit, friable, fineto very fine griined, subarigular to subrounded, clayey,

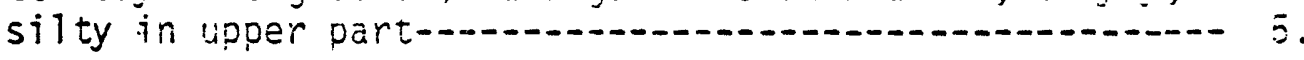

Coal, upper bench of Bed L_- 2.1

Sha1e, carbonacesus-1.-1 0.4

Giaystone (:0-1)**, medium-brown, yellow-weathering, silty;

abundant carbonaceous plant fragments-..............-.- 0.1

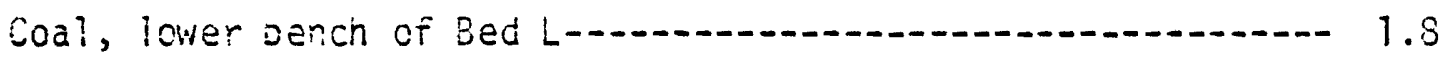

Siltstone (16P-2)* , yellowish-gray to light-gray-weathering, treaks to hiard anguiar cobble- and debble-sized pieces, clayey, carbonaceous ir upoer part; ablindant plant stem imprinis - -

Sandstone, medium-gray, angular-fracturing, silty-...........- 0.5

Covered26.3

Coai, shaiy-_an 0.3

Claystone, medium-gray, angular-fracturing, silty, very

silty in upper part; includes a $0.1-f t$. coaly clay-

stone bed $1.9 \mathrm{ft}$. above base-1.-1

Coal, uppermost part of Bed K- 0.4 
Claystone, medium-gray, ?ight-gray-weathering, anguiar-

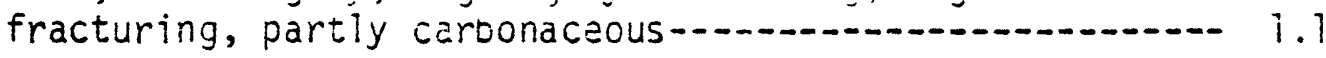

Coal- 0.2

Claystone, medium-gray, light-gray-weathering, angular-

fracturing, partly caroonaceous -......... 1.1

Coal-1

Shale, carbonaceous-1. 0.4

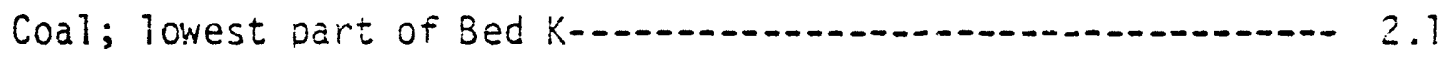

Sandstone, medium-gray, massive, soft, very silty-n.....- 


\section{Measured section $L 7$}

Location: West side of canyon of Swift Creek, in the SW $1 / 4$ IiW 1/4 Sec. 25, T. 4 S., R. 11 N., Seidovia D-3 quadrangie.

Feet

Tertiary rocks -- Kenai Group, Sterling Formation

Coal, Bed $Q(?)$; top eroded- $2.4+$

Siltstone, medium-gray, iron-stained, Iight-gray-waathering, poor ciaty-bedded, sandy; interbedded with about $35-40$ percent medium-gray iron-stained massive soft fine- io very fine grained sandstone in oecs up to $3 \mathrm{ft}$. thick; includes a $0.3-\mathrm{ft}$. carbonaceous shala bed $24.7 \mathrm{ft}$. above base-1.

Sandstore, medium-gray, iron-stained, yellowish-brown- to yeliowish-crange-weathering, thick-jedded, soft, fineto very fine grained-_. 2.4

Siltstone, medium-gray, iron-stained, light-gray-weathering, poor platy-bedied; oraaks to anguiar flakes, very clayey: siltstone in beds as mucr as $5 \mathrm{Tt}$. thick; interbeddej with about 25 percent sandstone similar to overlying unit in beds as mucn as $1.5 \mathrm{ft}$. thick

Shale, carionaceous

Coal-

Shale, carbonaceous- 0.5

Partly covered; nostly light-gray-weathering poor platybedded sandy siltstone; lower $2 \mathrm{ft}$. of unit more sanay; includes 0.3-ft. carbonaceous shale bed $2 \mathrm{ft}$. below top-.

Clinker; mostly burned and baked siltstone-1... 8.

Siltstone, medium-dark-gray, 1 ight-gray-weathering, angularfracturing, clayey-.. $i$.

Sandstone, medium-light-gray, iron-stained, yellowish-brownto yellowish-orange-weathering, thick-bedded, soft, fineto very fire grained-_... 
Claystone, medium-i ight-gray, angular-fracturing, si? ty;

abundant carbonaceous plant fragments -..................-.

Sandstone, medium-light-gray, partly iron-stained, vellowish-gray-weathering, massive, soft, fine- to very fine grained; some 0.4-7t. beds of silty claystone in lower

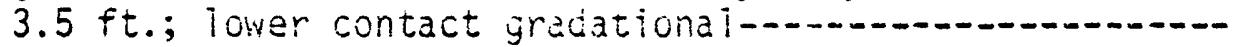

Claystone, dark-gray, medium- to light-gray-weathering, poor platy-bedded, angular-fracturing, silty; includes a $0.1-\mathrm{ft}$. carbonaceous shale bed $9.3 \mathrm{ft}$. abcve base-.... 15.2

Covered17 .

Siltstone, medium-? ight-gray, i ight-gray-weathering, poor

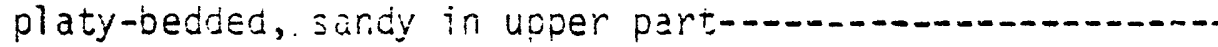

Sandstone, medium-crav, iron-stained, yellowish-brownweathering, trick-baddec, sott, itile- to very fine

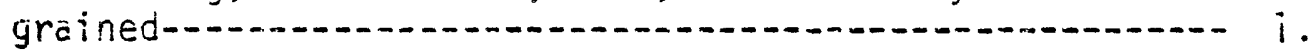

Claystone, niedinn-dark-gray, angular-fracturing, silty; abundant carbcraceous plant fragriencs; ircludes a

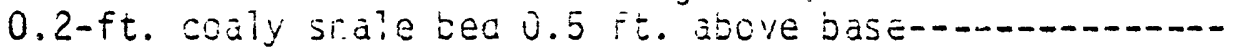

Sandstone, medium-dark-gray, iron-stained, yel? owish-brownweatnering, assive, soft, very fine to rine-grainec;

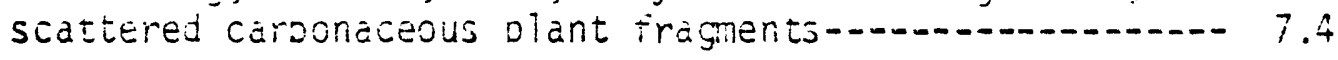

Siltstone, light-gray-weathering, poor platy-bedded; scattered carbonaceous plant iragments-.................- 5.4

Sandstone, medium-gray, iron-stained, yei iowish-brownweathering, thick-bedded, soit, fine- to very fine grained; carboraceous in interval $0.2 \mathrm{ft}$. tnick 0.9

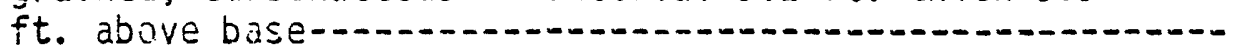

Claystone, medium-dark-gray, angular-fracturing, silty; abundant carbonaceous piant fragrents-................... 0.9

Sandstone, madium-gray, iron-stained, yelicwish-brownweatheing, thick-bedded, soft, fine- to very fine

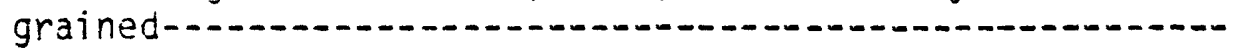

Siltstone, lignt-gray-weâthering, platy-bedded, flaky-_......- 5.5

Shale, platy-bedded, carbonaceous; interbeaded with about 50 percent yel?owish-brown-weathering platy-bedded sands tone- 


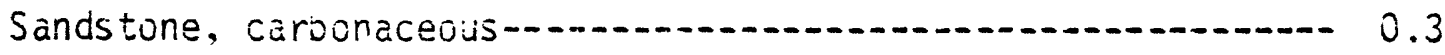

Sandstone, mediur-gray, iron-stained, yellowisn-brownweathering, fiaty-oedded, sot:, fine- to mediumgrained-1.-...- 0.2

Shale, carconacerus-a.n. 0.3

Covered-1.

Partly covered; rostly iron-staired i ight-gray-weathering

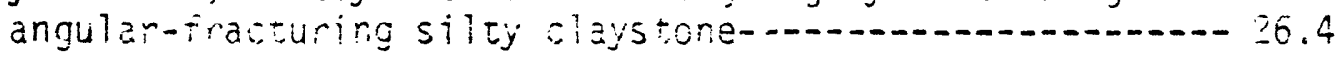

Sandstone, medium-aerk-gray, iron-stained, rassive weathering, cross-laminated wi th caroonacecids meterial, mediumgrained in lower part to fine-grained in upper part-...-.- it.

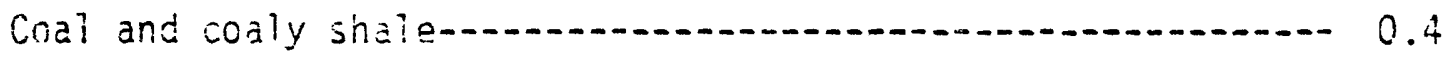

Ciavstone, recium-gray, very silty in upoer part;

interbeded witn ienticular caroonaceous clay-

stone-1.-1. 5.4

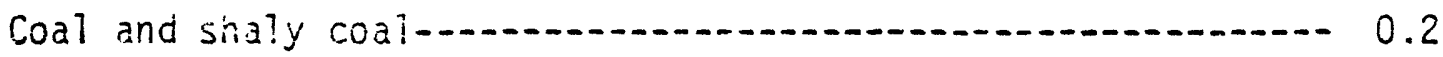

Shale, coaiy-1.

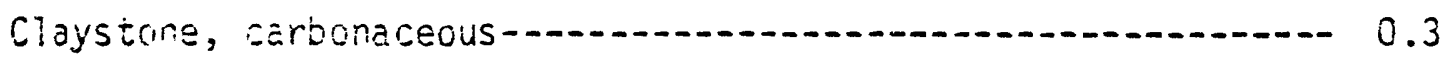

Shale, coaly- 0.5

Claystone, carbonaceous-a.-. 0.2

Coal

Claystone, i grit-gray-weathering, fiaky, siightly carbo-

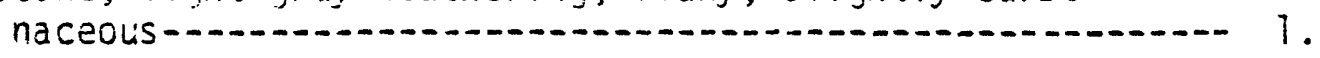

Coal- 0.4

Siltstone, light-gray-weathering, angular-fracturing-.......-. 2.+ 
Measured section L8

Location: Sea-cliff exposures in the SE $1 / 4$ SW $1 / 4$ sec. $25, T, 5$ S., R. 12 w. Seicovia $C-4$ audarangle. This is near iocality 140 of Barnes and Cobb (1959, p1. 13).

Feet

Tertiary rocks -- Kenái Group, Beluga Formation (upper part)

Coa? 0.5

Sandstone $(-8-2) * x$. dark-gray to redium-brown, soft, plastic, fine-grained, anguiar to suangliar, very clayey, volcanic?; this is ana same unit as sampied

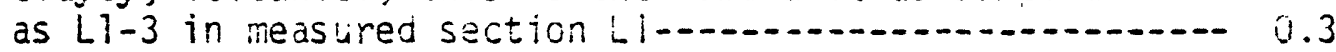

Coal 2.

Siltstone, medium-gray, inght-gray-ieathering, sandy in lower part, clayey at top; lower contact gradational--.-- 21.5

Sarldstone, medium-gray, i ight-gray-weathering, massive, very iire to firie-graired, silty, ciavey; lcier oart with calcarscus cement in piaces and rounced concretionary form; unit forms near-vertical cifff.........- 54:5

Siltstone, medium-gray, light-gray-weathering, thickbedded, angular-fracturinç, soft; iower contact

gradational-1.......

Claystone, carboraccous in lower part, silty iri upper

part-1-2.1.

Coai-1.+D. 0.5

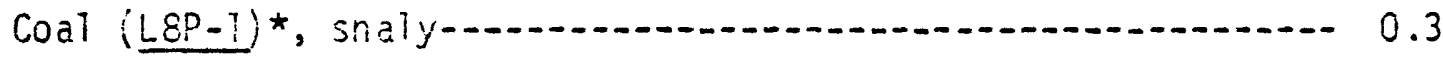

Siltstore, medium-gray, light-gray-weathering, coscurely bedded, fan conriy developed cross-beds snown by

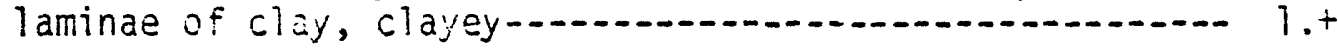




\section{Measured section 19}

Location: Sea-cliff exposure west of measured section L3 in the NE 1/4 NW $1 / 4$ sec. $35, T .5$ S., R. 12 W., Seldovia $\mathrm{C}-4$ quadrangle.

Feet

Tertiary rocks -- Karai Group, Beluga Formation (upper part)

Base of shaly coal unit sampled as $(\underline{\mathrm{LPP}-1}) *$ in measured section $L 8$.

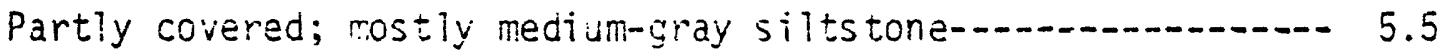

Sandstone $(\underline{(\underline{g}-5) * \pi}$, madium-dark-gray, massive, soft, friable, rostiy fine- to medium-grained, subrounded,

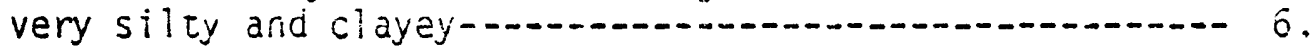

Sandstone (L9-5)**, dark-gray, massive, soft, friable, fine- io mediun-graned, subraurded, sil ty, ciayey; abundant durk rock fragmenis; forms rounded sniwotn-

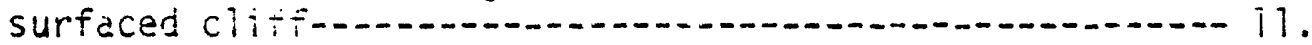

Partly covered; rustly medium-light-gray-weathering silts tore-1.

Concretion (19-4)**, nedium-gray, iror-stained, yallowishgray-rounded-reathering, rard, calcarecus, clayej; includes in places a $0.1-f t$. coal at base; lower contact wavj-1-.-

Siltstone, medilim-gray, light-gray-weathering, obscurely

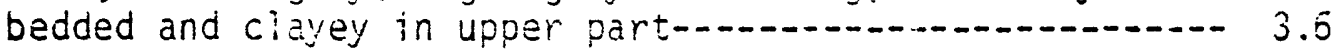

Sandstone $(\underline{(9-3) \times \star, ~ m e d i u m-d a r !-g r a y, ~ m a s s i v e, ~ s o f t, ~}$ friable, fine- to mediuri-grained, subrounded to subangular, silicy, clayey; asungant rock fragments-.........- io.

Partly covered; mustly mediun-gray soft claystone-............- 6 .

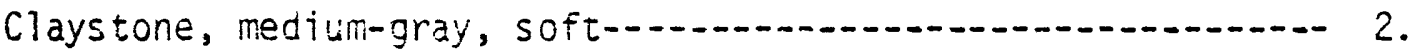

Coal, shaly; coal-1.2

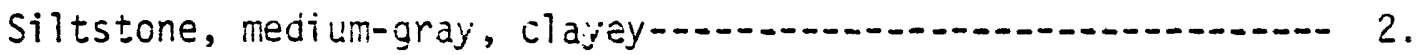

Shale, coaly-a 0.1

Clay, carbonaceous-1 0.1

*Palynological samole

**Lithological samiple 
Sandstone (LO-2) ${ }^{\star *}$, medium-dark-gray, massive, soft, friable, fine- to very fine grained, subanguiar to sibrounded,

silty, veiy clayey in upper $0.5 \mathrm{ft.} \ldots \ldots$

Claystone, mediuri-gray, i ignt-gray-weathering, soft,

slightly carionacesus in icwer part, siity and

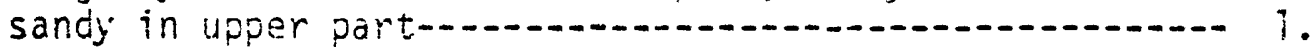

Coal-1-20-1

Siltstone (19-1)*+, medium-gray, light-gray-weathering,

anguiar-tracturing, hard, very clayey, silgntiy

carboracaous; scattered carbcnaceous plant frag-

ments

2.

Coal

0.1

Claystone, lignt-brownish-gray-weathering, very silty,

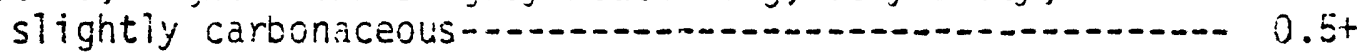


Measured section L10

Location: Sea-cliff exposure west of measured section LS in the NW $1 / 4$

NW $1 / 4$ sec. $35, T .5$ S., R. 1? W., Seldovia C-4 quadrangle.

Feet

Tertiary rocks -- Kenai Group, Beluga Formation (upeper part)

Base of $0.1-f t$. ccal bed in lower part of measured section L9.

Sandstone (LiO-3 -- from lower nart of unit) $* *$, mediumdark-gray, rassive, smooth-faced cliff-forming, friable, very fine to fine-grained with sore redium grains, subrounded to subangular, silty, clave; abundant dark rock fragments; upoer part of unit very silty, clayey and soiter than rest of unit-..-....-.- 58.

Siltstone, medilim-gray, soft, very clayey, sandy in upper part-...........

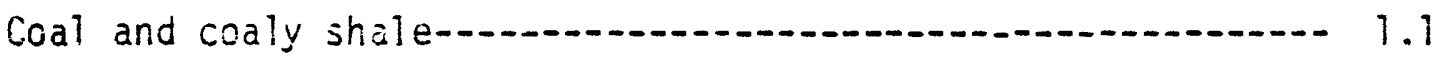

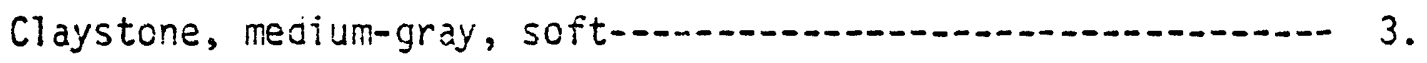

Coal and coaiy shaie $($ LiOF-2)* 
Measured section $\$ 11$

Location: Sea-cliff exposures west of measured secticr LiO in the NW $1 / 4 \mathrm{Nw} 1 / 4 \mathrm{sec} .35, \mathrm{~T} .5 \mathrm{~S} ., \mathrm{R} .12 \mathrm{k}$. , Selidovia C-4 quadrangie.

Feet

Tertiary rocks -- Kenai Group, Beluga Formation (upper part)

Base of the C.2-ft. coaly unit at base of measured section Lio.

Sandstone (LI1-2)**, medium-gray, yellowish-gray-weathering, steep-cliff-forming, massive, few cross-laminae shown

by carbonaceols olant fragments, friable, fine- to medium-grained, subrouncied, silty, clayey; asundant dark rock fragments; some rounded caicareous concretionary masses near miadle and at top-.................. 18.8

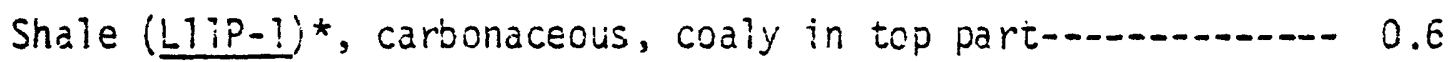

Coat--

Silts tone, medium-gray, light-gray-weathering, soft,

very clayey-...... 0.6

Coat 0.5 


\section{Measured section -12}

Location: Sea-cliff exposures west of measured section Lll in the SW $1 / 4 \mathrm{NW} 1 / 4 \mathrm{sec} .35, T .5 \mathrm{~S} ., \mathrm{R} .12 \mathrm{iN}$. , Seldovia C-4 quadrangle.

Feet

Tertiary rocks -- Kenai Group, Beluga Formation (upper part)

Base of 0.5-ft. coal at base of measured section LII.

Sandstone (1,2-?)**, medium-dark-gray, massive, soft,

friable, very tine to fire-grained, subanguiar to

subroundes, s11ty, clayey in upper part; ajundant

dark rook fragments-_._. 5.5

Partly covered; mostly medium-iigrt-gray angular-fracturing soft claystone-1.

Covered-1.

Coal, shaly-n...... 0.3

Partly roverad: rostly medium-gray sott si ightly silty

clays torie-

Coal, shaig-

Claystone $(\underline{L 12 P-1}) *$, carbonaceous-a.t.

Coal-

Claystone, silty in lower sart, carbonaceous in upper

part-... 0.4

*Palynological sample

**Lithological sample 
Measured section LI3

Location: Sea-cilff exposures west of measured section Li2 in the SE $1 / 4$ ite $1 / 4$ sec. 34, T. 5 S., 只 $12 \mathrm{i}$., Seidovia C-4 quadrangle.

Feet

Tertiary rocks -- Kenai Group, Beluga Fomation (upper part)

Base of 0.4-ft. silty claystone at base of measured section L12.

Sandstone $(-13-5 j * *$, redium-darix-gray, lignt-gray-weathering, massive, hard, fine- do very fine jraned, suangular, yy silty, clayey; scatterad carbonaceois plant fragrents; forms small cliffis with rounded

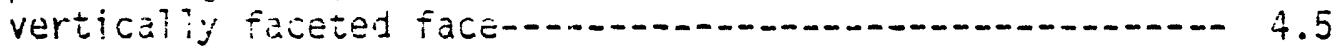

Covered-10.0. 3.3

Shale, coaly 0.2

Partly covered; riostly medium-gray soft claystone-............- 4.5

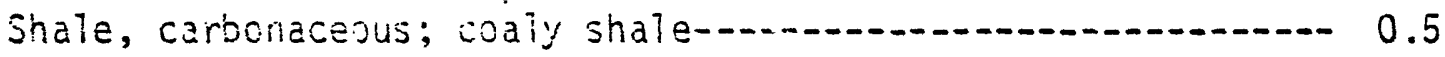

Coal-1 0.1

Ciaystone, medium-gray, siity, sandy-................................ 1.

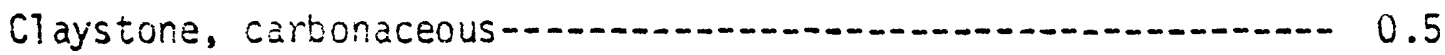

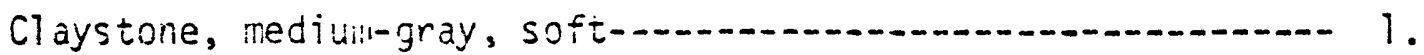

Sandstone, medilin-dark-gray, massive, soft, very fine grained, silty-_an 3.2

Partly covered; mostly medium-gray massive soft sandy

sij stone-1.-

Shale, coziy-1.5

Coal

Sandstone, medium-dark-gray, massive, soft, very fine grained, si ? cy-ar-a 3.2

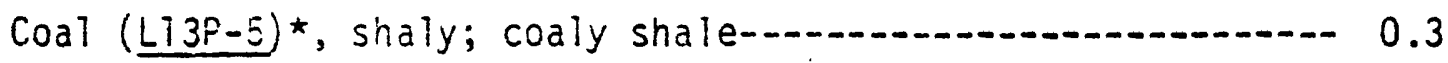

*Palynological sample

**Lithological sample 
Sandstore, medium-dark-gray, thick-bedded, soft, very fine to fine-grained, clayey, silty-........................ 1.1

Siltstone, medium-dark-gray, anguiar-fracturing-_...........- 2.

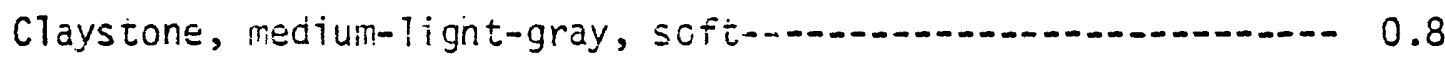

Shale, coaiy 0.4

Claystone, riedium-i ight-gray, soft, silty-....................... 1.7

Shale, codily-a.t. 0.4

Claystone, medium-1 ight-gray, soft, silty-..................... 4.5

Sandstone $(1 \mathrm{l3-4} \text {-- from } 2 \mathrm{ft} \text {. above base })^{\star x}$, mediumgray, massive, scft, friabis, fine- to riediumgrained, subrolnced, clayey, silty in lower part;

aburidant dark rock fragments-................................. 9.

Claystore (-13-3)**, medium-dark-gray, soft, very silty and sandy in uper parc; scattered carbcnaceous

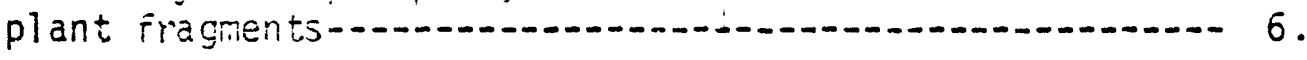

Coal, shaly-1 0.1

Claystone, rediumi-gray, soft-1. 0.8

Coal and shaiy coat-an 0.1

Claystorie, medium-gray, soft, siity-a............................ 2

Coal $($ Ll3P-2)*, shaly; interbedded with carbonaceous 40.2

Coal- 0.4

Sandstone (Li3-1 $)^{\star *}$, mediumi-dark-gray, massive, suft, very fine to fine-grained, subanguiar, very silty,

very clayey in upper part-................................ 5.

Partly covered; mostly medium-light- to medium-gray poor angular-fracturing soit claystore; includes

0.2-ft. coaly claystone bed about $6 \mathrm{ft}$. above base-......- 17.5

Coal- 0.3

*Paiynological sampie

** Lithological sample 


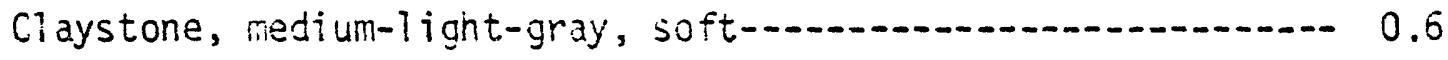

Coai

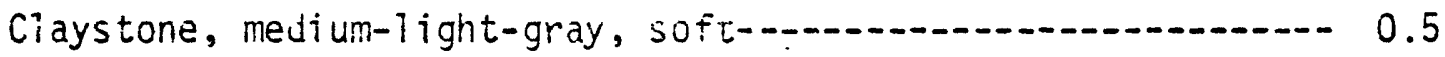


Measured section L14

Location: Sea-cliff exposures west of measured section $L 13$ in the SE 1/4 NE $1 / 4$ sec. $34, T .5$ S., R. 12 W., Seldovia $C-4$ quadrangie.

Feet

Tertiary rocks -- Kenai Group, Beiuga Formation (upper part)

Base of lowest unit of measured section L L 13 .

Partiy covered; mostly very silty sandstone, flayey

toward top; scattered calcareous concretionary parts----- 4.8

Sandstone $(L 14-3) * \star$, medium-gray, partiy iron-stained, thick-bミdded, partiy arguiar-fracturing, soft, friable, very fine grained, subanguiar, very silty,

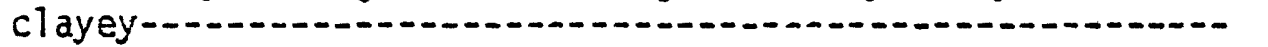

$\hat{\imath}$.

Partly covered; mostly medium-gray siitstone, clayey in

lower part-_..-

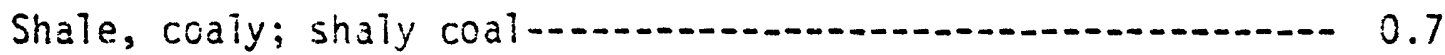

Siltstone, mediun-gray, angular-fracturing, clayey--.--.---- 7.1

Partly covered (L:4-2 -- from lower part of unit)**; mostly meciulil-gray angular-iracturing soft slightly

silty ciaystone with scattered carbonaceous plant

fragments-1...-..- 5.8

Claystone (L14P-1 -- from lower part of unit)*, carbo-

naceous; scattered laminae and ienses of coal-...........- 2.

Coal-1

*Palynological sample

** Lithological sample 
Measured section L15

Location: Sea-cliff exposures west of measured section L14 in the SW 1/4 NE $1 / 4 \mathrm{sec}$. 34, T. $5 \mathrm{~S} .$, R. $12 \mathrm{w}$., Seldovia C-4 quadrangle.

Feet

Tertiary rocks -- Kenai Group, Beluga Formation (upper part)

Base of lowest unit of measured section L14.

Partly covered; mostly medium-gray soft very clayey

si its tone-1-2-1.-1

6.8

Coal, shaly; coal-_.-. 0.4

Claystone $\left(\lfloor 15-4)^{\star *}\right.$, medium-dark-gray, partly ironstained, soft; scattered sana grains-.................... 5.

Sandstone (LIE-3 -- from lower $3 \mathrm{ft}$. of unit)**, mediumdark-gray, massive, some low-angie cross-bedding shown by carconaceolis plant material, soft, friabie, fine- to very fine grained, subanguiar to subrounded, silty, clayej; ábuncant dark rock iragments-.............- 14.2

Partly covered (Li5-2 -- from lower part of unit)**; mostly mecium-uark-gray soft very silty claystone with small scattered carboriaceous plant fragments-.-.-.--- 11.5

Sandstone $: \angle 15-1 A$-- from lower part of unit)** (LI5-TB -from upper part of unit) ${ }^{\star x}$, dark-gray, light-grayweathering, massive, some low-angle cross-bedding shown by carbonaceous plant fragments, soft and friable in lower part, harder in upper part, mediumgrained in lower part to fine-grained in upper part, subrounded, clayey in lower part, sitty in upper part; large woudy carbonaceous jiant fragments in lower part; scattered rounded concretionary bodies as much as $4 \mathrm{rt}$. in diameter; forms bold cliff-.......... 24. 
Measured section L16

Location: Sea-cliff exposures west of measured secticn Lis in the SW $1 / 4 \mathrm{NE} 1 / 4 \mathrm{sec} .34, \mathrm{~T} .5 \mathrm{~S} ., \mathrm{R} ., 12 \mathrm{H}$., jelciovia $6-4$ quadrangle.

Feet

Tertiary rocks -- Kenai Group, Beluga Formation (upper part)

Base of lowest unit in measured section L15.

Coai

0.2

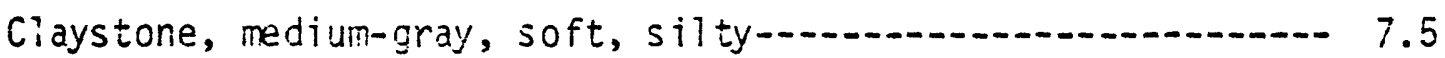

Sandstone (116-3 -- from lower part)**, dark-gray, massive, soft, friable, medium- to fine-grained in lower part, very fine grained to silty in upoer part, subrounded, clayey; abundant dark rock fragments; includes calcareous concretionary parts as much as $6 \mathrm{ft}$. long in upper part-17.5

Coat 0.1

Partly covered; mostly medium-dark-gray silty claystone--.-.- 8.4

Shale, carbonaceous; coaly shale-........................... 0.2

Partly covered; lower part of unit mostly medilim-darkgray angular-fracturing soft very clayey silty sands tone; upper part mostly medium-dark-gray soft silty clays tone-1 9.7

Partly covered; mostly medium-gray soft clayey siltstone-1.-.- 6 .

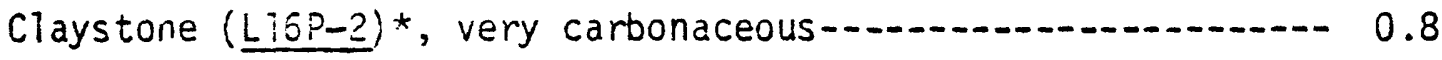

Coal and shaly coal- 0.2

Siltstone, medium-dark-gray, soft, clayey to very clayey in upper part; includes a $0.05-\mathrm{ft}$. coal at $6.4 \mathrm{ft}$.

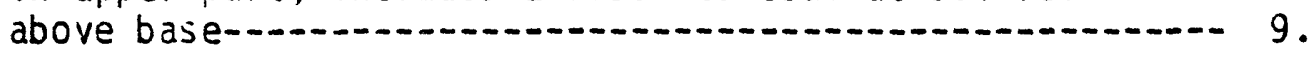

Coal 0.2

Siltstone $(\underline{L 16 P-1})^{*}$, medium-gray to brownish-gray, soft, very clayey, carbonaceous-_..... 0.5

*Palynological sample

**Lithological sample 


\section{Measured section LiT}

Location: Sea-cliff expcsures west of measured section 176 in the NE 1/4 SW 1/4 sec. 34, T. 5 S., R. 12 N., Seldovia C-4 quadrangle.

Feet

Tertiary rocks -- Kenai Group, Beluga Formation (upper part)

Base of jowest unit of measured section L16.

Claystone, medilir-dark-gray, light-gray-angular-weathering, silty, slightly carbonaceous in lipper part-......... 3.

Siltstone, dark-gray, light-gray-weathering, thick-bedded,

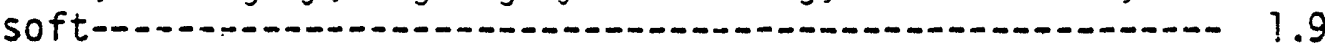

Sandstone (1-17-3)**, medium-light-gray, yellowish-grayweathering, partiy massive, some poorly defined planar cross-bejuing, soft, friacle, mostly mediumgrained, subrounded, clayey, very silty, partiy pebbly with few cobbies; includes laminae and lenses, $0.2-1$. ft. thick, of fine- to very fine grained subangular sandstone; forms a fiuted ledge-.............. 13.6

Claystone, medium-dark-gray, soft, silty, carbonaceous

in lower part; includes 0.1 by $0.2-\mathrm{ft}$. iron-stained

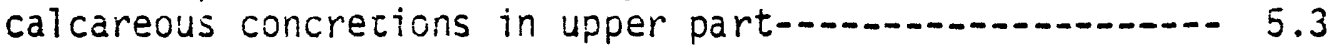

Coã 1.2

Claystone, medium-dark-gray, light-gray-weathering, angular-fracturing, soft, carbonaceous in upper

$0.2 \mathrm{ft} . \ldots 1.0$

Coal-1 0.9

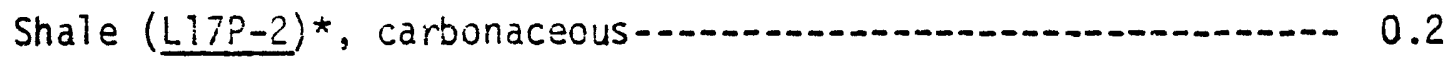

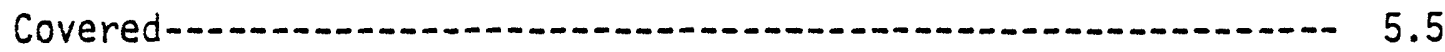

Partly covered; mostly medium-dark-gray clavey siltstone; includes scattered calcareous concretionary parts 2

$\mathrm{ft}$. thick by $6 \mathrm{ft}$. long about $6 \mathrm{ft}$. above base-.......-.- 13.5

Partly covered; mostly medium-dark-gray (1ight-grayweathering) angular-fracturing silty claystone-..--.---.- 4.

Coal and shaly coal-_.-. 0.5 *Palynological sample **ithological sample 
Partly covered; mostly medium-dark-gray (1ight-grayweathering) anguiar-fracturing claystone, slightiy carbonaceous in lower part and silty in upper part; includes a $0.1-\mathrm{ft}$. carbonaceous shale about $0.2 \mathrm{ft}$. above base-1-.-- 10.4

Coat 1.

Claystone $\left(L 17 P_{-i}\right) *$, dark-gray, carbonaceous, siightly

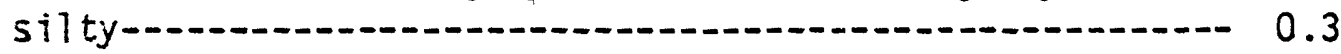

Coai-1-2 0.4

Ccal, shaly-an 0.5

Claystone, dark-gray, carbonaceous, slightly silty-.........- 0.5 


\section{Measured section L18}

Location: Sea-cliff exposures west of measured section Li 7 in the NE $1 / 4 \mathrm{SiN} 1 / 4 \mathrm{sec}$. $34, \mathrm{i} .5 \mathrm{~S}$.; R. $12 \mathrm{~W}$., Seldovia C-4 quadrangle.

Feet

Tertiary rocks -- Kenai Group, Beluga Formation (upper part)

Base of lowest unit of measured section Li7.

Partiy covered; mostiy soft very clayey siltstone-_-_.-... 5.7

Sandstone, medium-gray, thick-bedded, soft, very fine

grain $\leq$ d-. 2.4

Coal and coaiy sinale-1. 0.6

Sands tone, medium-dark-gray, massive, soft, fine- to very

fine grained-... 10.5

Siltstone, medium-gray, soft; includes scattered coaly

lenses as much as $0.1 \mathrm{ft}$. thick-a. 6 .

Coal and coaly shale 0.3

Siltstcne, mediun-gray, anguiar-fracturing, soft-_._. 2.6

Sancistone $(418-5) * \star$, medium-gray, massive, soft, friable,

very fine grained, subangular to subrounded, clayey,

silty in upper part-1.5 4.5

Siltstone, medium-gray, soft, coaly at top- 4.5

Coal and shaly coal- 0.2

Sandstone, medium-gray, thick-bedded, soft, very fine

grained, silty, clayey- 1.5

Coal-

Siltstone, medium-dark-gray, soft, very olayey-_.-. 2 .

Sandstone, medium-dark-gray, thick-bedded, soft, fine-

grained-1. 2.5

Claystone, medium-dark-gray, silty-a 2.8

**Lithological sample 
Sardstone, medium-dark-gray, cross-bedded at angles of 45-50 degrees in pianar!?) sets, fine- to very

fine grained, silty, clayey; includes scattered

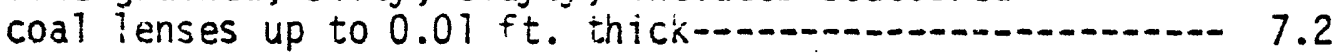

Siltstone (\$18-4)**, dark-gray, soft, very ciayey; in-

cludes few medium-dark-gray calcareolis concretionary

parts up to $8 \mathrm{ft}$. long with few carbonaceous plant

fragments -

Claystone, medium-gray, soft-a. 0.4

Coal

Ciaystone, dark-gray, sligntly carbonaceous-_...................... 0.2

Coal, shaly-a. 0.2

Coal

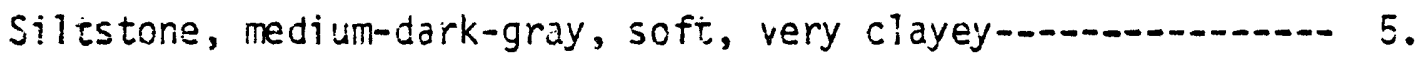

Coal-2. 0.2

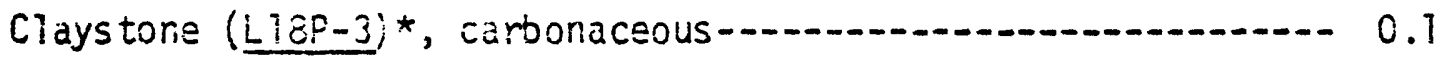

Coal- 0.2

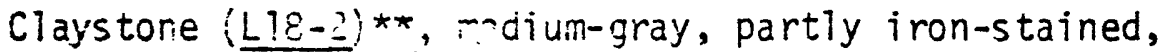
soft, sijti in part; abundant carbonaceous plant

fragments--...- 2.

Coal

0.7

Sands tone $(\text { Li8-i })^{* *}$, dark-gray, thick-bedded, soft, friable, fine- to very fine grained, subrounded to subangular, silty, clayey; abundant dark rock fragments----- 2.2

Siltstone, medium-gray, soft, very clayey-......................... 3

Shale, coaly-ar 0.2

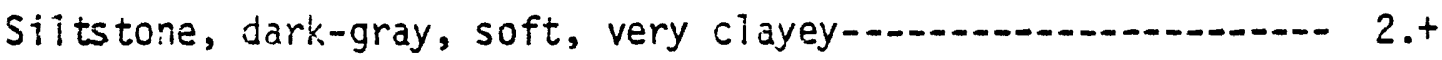

